UNIVERSIDADE DE SÃO PAULO

INSTITUTO DE GEOCIÊNCIAS

\title{
ANÁLISE DE FÁCIES E PROVENIÊNCIA SEDIMENTAR EM SAMBAQUIS DO LITORAL CENTRO-SUL DE SANTA CATARINA
}

\author{
Priscila Melo Leal Menezes
}

Orientador: Prof. Dr. Paulo César Fonseca Giannini

\author{
DISSERTAÇÃO DE MESTRADO \\ Programa de Pós-Graduação em Geoquímica e Geotectônica
}

São Paulo

2009 
Autorizo a reprodução total e/ou parcial deste trabalho, desde que citada a fonte.

São Paulo, 30 de junho de 2009

Priscila Melo Leal Menezes

leal.priscila@gmail.com

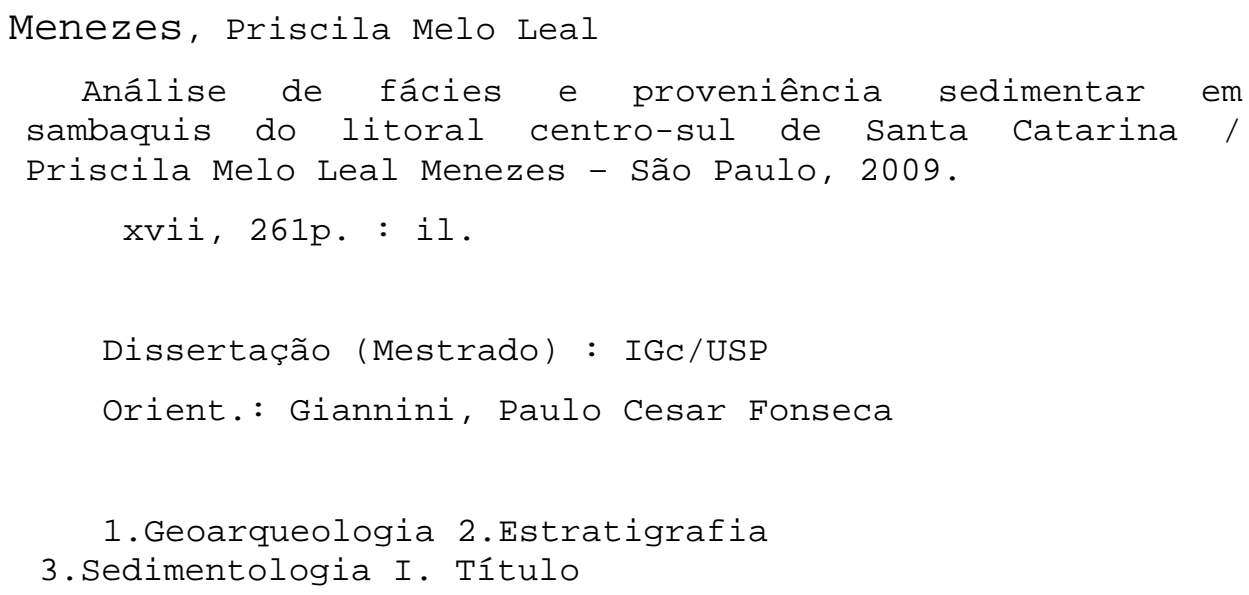




\section{AGRADECIMENTOS}

Esta seção da dissertação não é suficiente para retribuir a incrível vivência que as pessoas nela envolvidas me proporcionaram. Foram ganhos enormes em aprendizado e amadurecimento que só com o tempo darei conta de retribuir. De todas as pessoas quero deixar registrada minha gratidão:

Ao Paulo César Fonseca Giannini, à quem quero citar Fernando Pessoa (Ricardo Reis):

Mestre, são plácidas

Todas as horas

Que nós perdemos, Se no perdê-las, Qual numa jarra, Nós pomos flores.

Não há tristezas

Nem alegrias

$\mathrm{Na}$ nossa vida.

Assim saibamos,

Sábios incautos,

Não a viver,

Mas decorrê-la,

Tranqüilos, plácidos, Lendo as crianças Por nossas mestras, Não vale a pena Fazer um gesto. Não se resiste $E$ os olhos cheios Ao deus atroz De Natureza ... Que os próprios filhos Devora sempre.

À beira-rio,

Colhamos flores.

À beira-estrada, Conforme calha, Molhemos leves Sempre no mesmo As nossas mãos Nos rios calmos, Leve descanso De estar vivendo. Para aprendermos Calma também.

O tempo passa,

Não nos diz nada.

Envelhecemos.

Girassóis sempre

Fitando o sol, Da vida iremos Saibamos, quase Tranqüilos,tendo

Maliciosos,

Sentir-nos ir. Nem o remorso

De ter vivido.

Esta dissertação é resultado de um trabalho conjunto cujos membros deste grupo, além do orientador, quero agradecer:

Ao Daniel "Pegmatito" R. do Nascimento Jr, Ana Paula "Treme" Burgoa Tanaka, Milene "Prenda" Fornari, Paula "Pi" Amaral, Prof. André "Fruta" O. Sawakuchi, Ximena S. Villagrán e Carlos Conforti F. Guedes. 
Agradeço ainda, a grande contribuição prestada por:

Vitor Angelo Aguiar, Isaac Jamil Sayeg, Adriano José de Souza, Simone Campos Carrera, Daniela Leonel Borges, Prof. José Moacyr Vianna Coutinho, Prof. Ian McReath, Prof. Thomas Rich Fairchild, Prof ${ }^{\mathrm{a}}$. Ana Góes, Rodrigo "Portuga", Prof. Daniel Atencio, Juliana Mendes Oliveira e Rebeca dos Santos Cardoso.

Do Instituto de Pesquisas Tecnológicas - IPT, quero agradecer aos meus companheiros de anos de pesquisa e amizade, responsáveis por grande contribuição a este trabalho:

Mírian Cruxên Barros de Oliveira, Eduardo Brandau Quitete, Nilson de Paula, Jilson Cardoso, Maurício Ornelas, Lúcia Dozzi, Thaís Noffs Battestin, Eli Arruda, Valdecir Angelo Quarcioni, Maria Heloísa Barros de Oliveira Frascá e Vilmondes Ribeiro.

Do Centro de Energia Nuclear na Agricultura - CENA, sou muito grata à:

Prof. Luiz Carlos Ruiz Pessenda, Rodrigo e Jaime Passarin.

Quero muito agradecer a ajuda que recebi em casa, onde a face da angústia era verdadeiramente exposta e, docemente acalentada pelo meu companheiro, melhor amigo e "sempre" professor Arnaldo Menezes Junior.

Por fim, você que está procurando seu nome nesta lista e, por esquecimento, cometi a injustiça de deixá-lo(a) de fora, aceite minhas sinceras desculpas. 


\section{Resumo}

Os sambaquis do litoral sul brasileiro são marcos paisagísticos, com valor histórico e científico. Constituem-se, predominantemente, de conchas de moluscos e sedimentos com marcante presença de matéria orgânica, empilhados em conformações estratigráficas variadas. Neste trabalho, elegeram-se como objetos de estudo três sambaquis da costa centro-sul de Santa Catarina, com dois tipos de conformações distintas: de um lado, os sambaquis Carniça III e Encantadas III, e, de outro, o Jabuticabeira II, maior e estratigraficamente mais complexo. A proposta é auxiliar na reconstrução dos hábitos e costumes dos povos que viveram nesta área litorânea durante grande parte do Holoceno "pré-descobrimento", e inferir suas relações com a evolução do ambiente geológico que os cercava. Para isso, foca-se em duas metas ou objetivos maiores: a aplicação de análise de fácies e de arquitetura deposicional nos sambaquis selecionados; e a investigação do uso de sedimentos paleolagunares como seu material construtivo. Para buscar estes objetivos, utilizou-se uma abordagem multi-analítica, que compreendeu: análise de fácies; determinação dos teores de matéria orgânica e carbonatos mais fosfatos; caracterização da fração grossa por lupa; granulometria; mineralogia de grãos pesados; estudo petrográfico e micromorfológico em seção delgada; microscopia eletrônica de varredura; e geoquímica e isotopia de carbono e nitrogênio.

A estratigrafia dos sambaquis Carniça III e Encantada III é composta por um núcleo arenoso sobreposto por camada preta orgânica rica em conchas e artefatos antrópicos ("terra preta", codificada como fácies LA). Em contraste, o sambaqui Jabuticabeira II caracteriza-se pela intercalação entre camadas conchíferas e lâminas pretas contendo sepultamentos (fácies "funerária", codificada como Lc), capeada por camada de "terra preta", rica em artefatos e sepultamentos. Por meio da análise de fácies, foi possível distinguir neste sambaqui três associações, da base para o topo: cascalho-lamosa, arenolamosa e cascalho-arenosa. A sucessão vertical destas associações reflete o assoreamento progressivo do sistema lagunar e configura assim a relação do sambaqui com o ambiente deposicional do entorno. As associações de fácies, de qualquer hierarquia, são delimitadas pelas lâminas da fácies Lc.

As análises do material construtivo utilizado nos sambaquis indicaram proveniência a partir das feições deposicionais mais próximas aos sítios, representadas por fundo, margem e brejo lagunar, nos casos dos sambaquis Jabuticabeira II e Encantada III, e por cordões litorâneos lagunares e dunas eólicas superimpostas, no caso do sítio Carniça III. Os 
parâmetros granulométricos e os índices de minerais pesados revelaram controle sobretudo geográfico em sua distribuição.

A análise de componentes fosfáticos aliados aos sinais isotópicos do carbono e nitrogênio indicam grande processamento antrópico no material constituinte das lâminas "funerárias" e da "terra preta" do sambaqui Jabuticabeira II, com características de matéria orgânica putrefata, provável refugo do processamento cotidiano dos sambaquieiros. Já para o Carniça III e Encantada III, este processamento teria sido muito menor. 


\section{Abstract}

The sambaquis (also known as 'shell mounds' or 'shell middens') in the Brazilian southern coast are landscape references and bear historical and scientific value. They are predominantly constituted of mollusk shells and sediments and also hold a sound presence of organic matter, piled up in different stratigraphic configurations. In this work, three sambaquis in the central-southern coast of the Santa Catarina state have been chosen as objects of study. They present two distinct configuration types: on one hand, the Carniça III and the Encantadas III, and, on the other hand, the Jabuticabeira II, which is larger and stratigraphically more complex. The proposal is to assist on the reconstruction of habits and traditions of the people who lived in this coastal area during a great part of the Holocene period (before the Portuguese navigators arrived in Brazil in 1500), and to infer their relations with the evolution of the surrounding geological environment. Two main goals have been set for this purpose: the application of facies analysis and depositional architecture in the selected sambaquis; and the investigation of the use of sediments from paleo-lagoons as their construction material. In order to achieve these goals, a multi-analytical approach has been used comprising: facies analysis; quantity evaluation of organic matter and carbonates associated with phosphates; characterization of the thick fraction in stereomicroscope; granulometry; heavy grains mineralogy; petrographic and micromorphological study of the thin section; scanning electron microscopy (SEM); and both carbon and nitrogen geochemistry and isotopy.

The stratigraphy of the Carniça III and Encantada III sambaquis is composed of a sandy nucleus covered with a black organic layer full of shells and anthropic artifacts ("black soil", represented as LA facies). In contrast, the Jabuticabeira II sambaqui is characterized by an assorted sequence of shell layers and thin black layers containing burial remains ("funerary" facies, represented as LC) covered by "black soil", and full of artifacts and burials. According to the facies analysis results, three associations have been found in this sambaqui, from bottom to top: muddy-gravel, muddy-sand and sandy-gravel. The vertical sequence of these associations reflects the progressive aggradation of the lagoon system and it establishes, thus, the relation between the sambaqui and the surrounding depositional environment. The facies associations, in any hierarchy, are limited by the thin layers in the LC facies.

The analysis of the construction materials used in the sambaquis has set their provenance in the nearest depositional features to the sites, represented by the lagoon bottom, margin and swamp for the Jabuticabeira II and Encantada III sambaquis, and by coastal lagoon barriers and superimposed wind dunes for the Carniça III site. The 
granulometric parameters and the heavy minerals indexes have showed control, mainly geographic, in their distribution.

The analysis of phosphate components associated with the carbon and nitrogen isotopic signals shows great anthropic processing in the material which constitutes the "funerary" and the "black soil" layers found in the Jabuticabeira II sambaqui, with putrid organic matter characteristics, a probable waste from the day-by-day processing of the people who built the sambaquis. On the contrary, this kind of processing is supposed to have been much lower in the Carniça III and the Encantada III sambaquis. 


\section{SUMÁRIO}

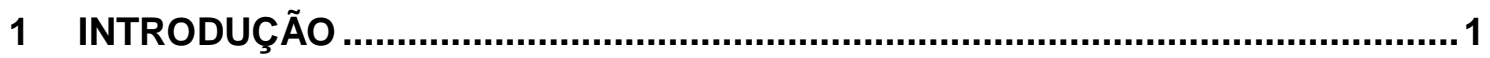

1.1 O INÍCIO: CONCEPÇÃO E CONSTRUÇÃO DO PROJETO................................................ 1

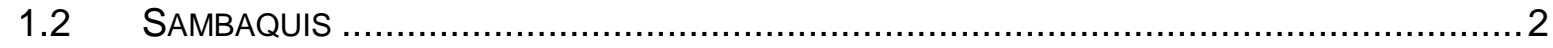

1.3 CONTEXTUALIZAÇÃO REGIONAL: SISTEMAS DEPOSICIONAIS E SAMBAQUIS ..................... 3

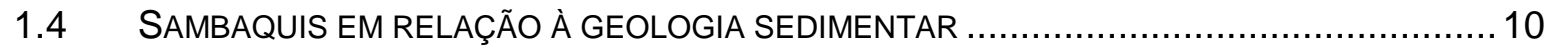

1.5 MATÉRIAS PRIMAS GEOLÓGICAS NA CONSTRUÇÃO DE SAMBAQUIS ............................ 11

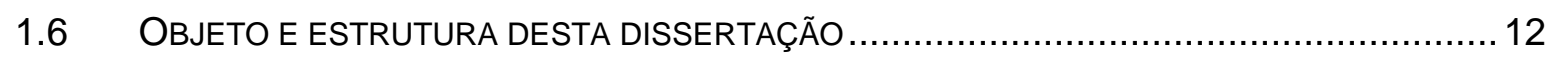

2 METAS E OBJETIVOS ................................................................................. 15

3 MÉTOdOS DE ABORDAGEM: DISCUSSÃO CRÍTICA ..................................... 16

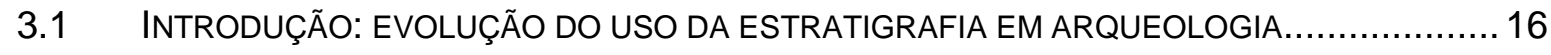

3.2 USOS DO CONCEITO DE FÁCIES E TERMOS ASSOCIADOS …................................. 18

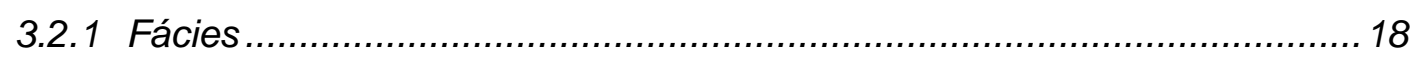

3.2.2 Análise de fácies...................................................................... 19

3.2.3 Associações de fácies .................................................................... 21

3.2.4 Elementos arquitetônicos e superfícies delimitantes..............................23

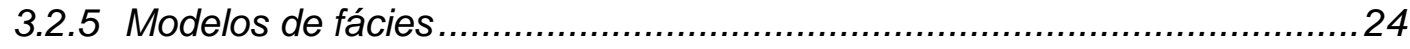

3.2.6 Aplicações de análise de fácies na estratigrafia de sambaquis................26

3.2.7 Exercício teórico - análise de fácies em arqueologia............................... 30

3.3 VISÃO EXTRA-SÍTIO: A CORRELAÇÃO SAMBAQUIS VERSUS SISTEMAS DEPOSICIONAIS .. 31

3.4 EXAME MICROSCÓPICO: O CASAMENTO DA MICROMORFOLOGIA COM A PETROGRAFIA

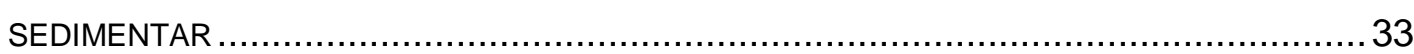

3.4.1 Feições pedogenéticas e sedimentares................................................. 35

3.4.2 Aplicações em arqueologia ............................................................... 42

3.4.3 Particularidades da micromorfologia aplicada a depósitos arqueológicos . 43

3.4.4 Uma proposta de abordagem integrada............................................ 43

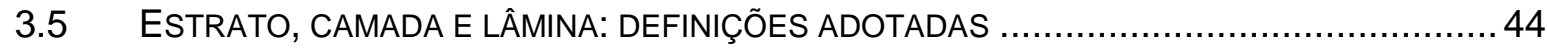

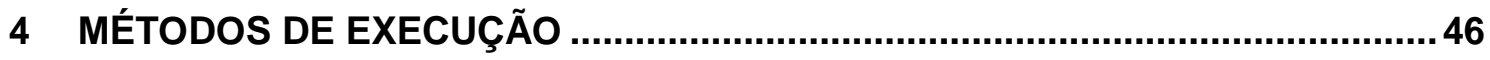

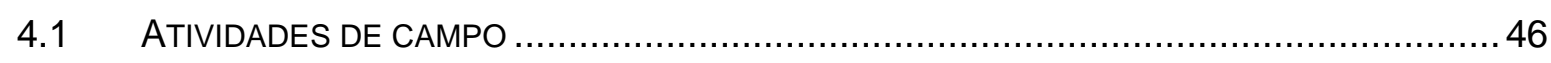

4.1.1 Descrição e coleta de amostras .................................................... 46

4.1.2 Códigos de amostragem .................................................................... 54

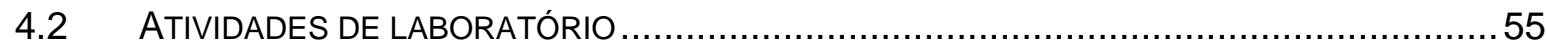

4.2.1 Determinação do teor de matéria orgânica total e carbonatos .................. 60 


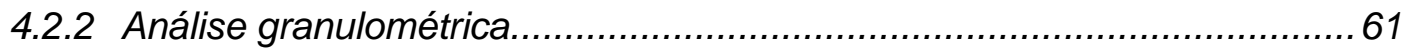

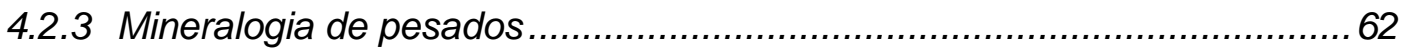

4.2.4 Análise da fração grossa sob microscópio estereoscópico .......................63

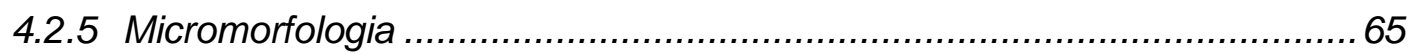

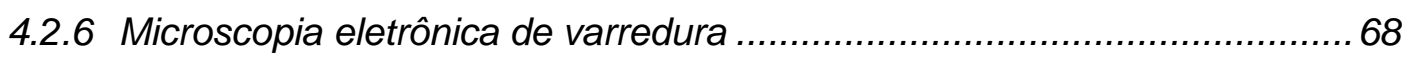

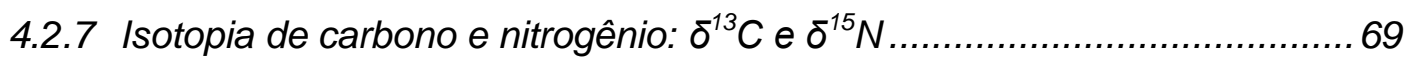

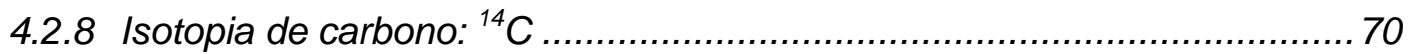

4.2.9 Tratamento estatístico .................................................................... 71

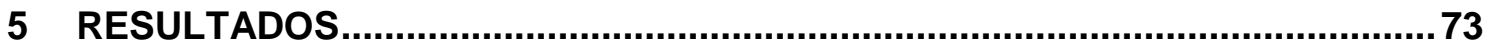

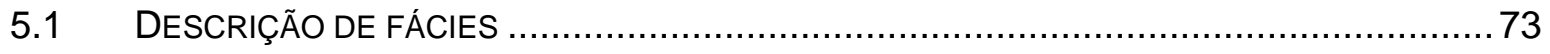

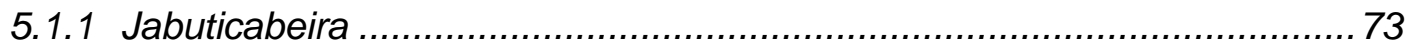

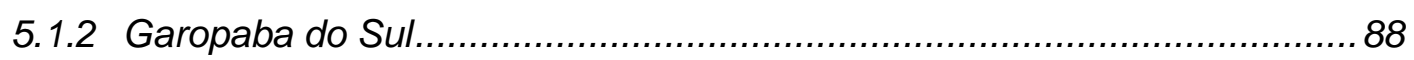

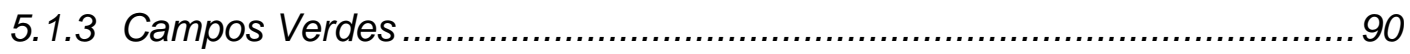

5.2 DETERMINAÇÃO DOS TEORES DE CARBONATO, FOSFATO E MATÉRIA ORGÂNICA TOTAL 94

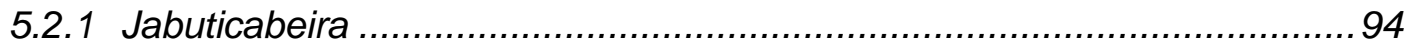

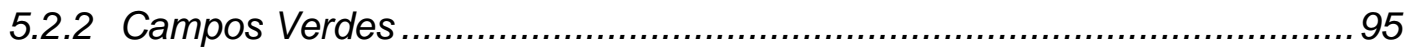

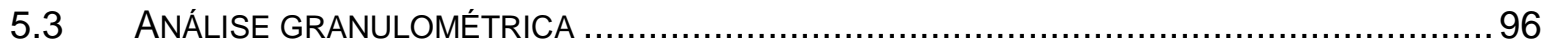

5.3.1 Jabuticabeira - distribuição das classes de areia.................................96

5.3.2 Garopaba do Sul - distribuição das classes de areia...............................99

5.3.3 Campos Verdes - distribuição das classes de areia ...............................98

5.3.4 Geral - distribuição das classes de areia........................................... 98

5.3.5 Jabuticabeira - parâmetros estatísticos .............................................98

5.3.6 Garopaba do Sul - parâmetros estatísticos .......................................... 99

5.3.7 Campos Verdes - parâmetros estatísticos........................................... 99

5.3.8 Diagramas de dispersão de parâmetros estatísticos da granulometria ... 101

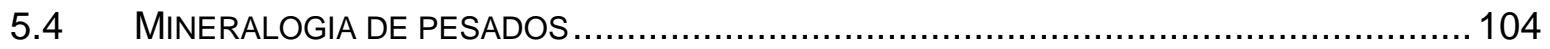

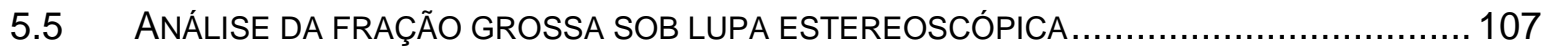

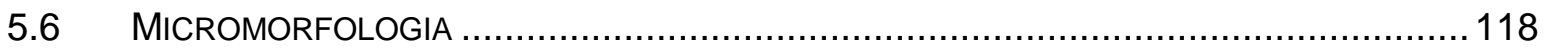

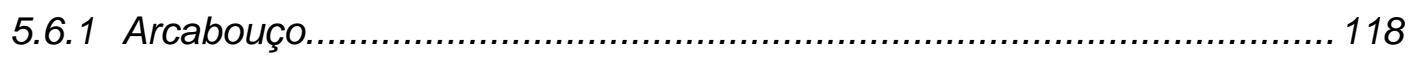

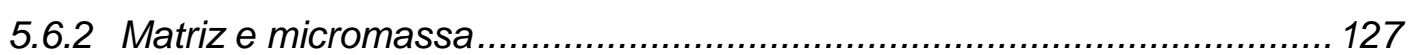

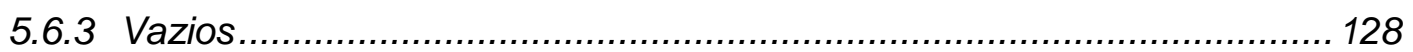

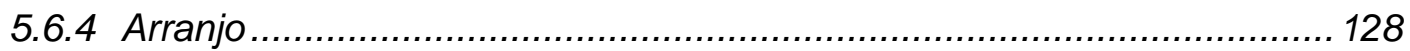

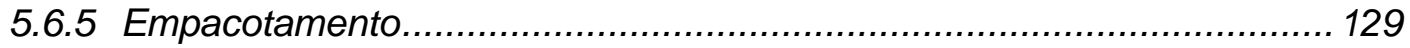

5.6.6 Porosidade................................................................................ 129

5.7 MICROSCOPIA ELETRÔNICA DE VARREDURA - MEV ........................................ 132

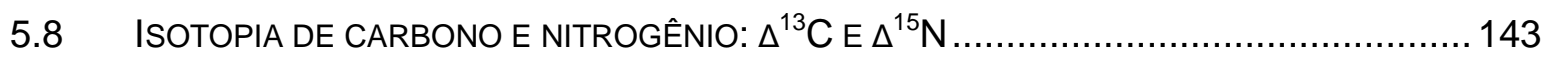


5.9 ISOTOPIA DE CARBONO: DATAÇÃO ${ }^{14} \mathrm{C}$ 149

6 DISCUSSÃO DOS RESULTADOS 153

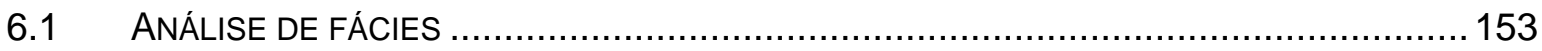

6.2 PROVENIÊNCIA dos SEDIMENTOS dos SAMBAQUIS JABUtICABEIRA II, CARNIÇA III E

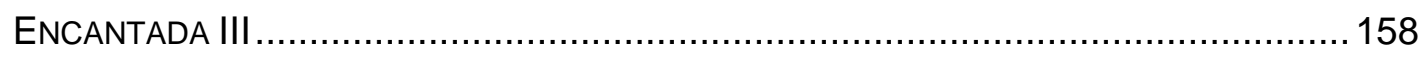

6.2.1 Origem dos materiais arenosos não orgânicos .................................... 158

6.2.2 Origem da matéria orgânica....................................................... 159

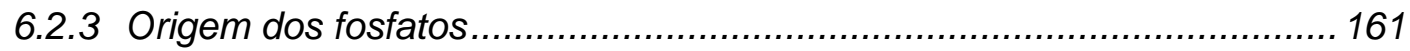

6.2.4 Origem e transporte dos materiais constituintes das fácies orgânicas do Jabuticabeira II 163

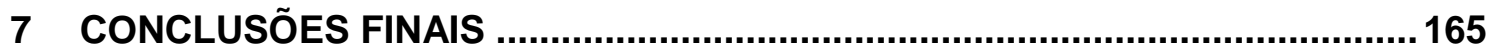

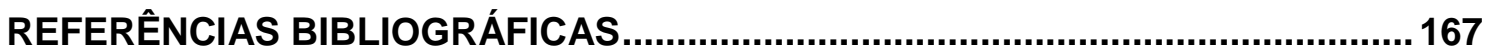




\section{Tabelas}

Tabela 1- Exemplo de análise de fácies. Modificado de Rossetti et al. (2004)............. 20

Tabela 2 - Componentes e propriedades na descrição petrográfica de rochas sedimentares (ou sedimentos endurecidos), conforme proposto por Giannini (2006)........... 39

Tabela 3 - Componentes e propriedades na descrição pedográfica (ou micromorfológica), conforme proposto por Stoops (2003) .......................................... 40

Tabela 4 - Listagem das amostras coletadas e as análises a que foram submetidas. . 56

Tabela 5 - Resumo da descrição de campo das fácies do sambaqui Jabuticabeira II. . 76

Tabela 6 - Resumo da descrição de campo das fácies dos sedimentos geogênicos

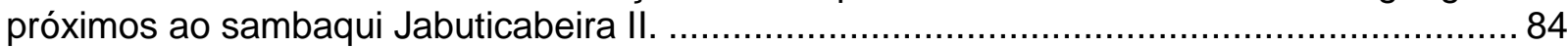

Tabela 7 - Resumo da descrição de campo das fácies do sambaqui Encantada III...... 88

Tabela 8 - Resumo da descrição de campo das fácies dos sedimentos geogênicos

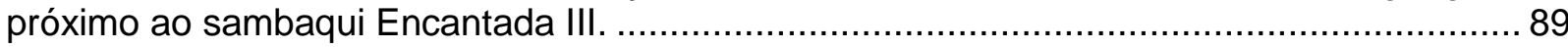

Tabela 9 - Resumo da descrição de campo das fácies do sambaqui Carniça III. ......... 91

Tabela 10 - Resumo da descrição de campo das fácies dos sedimentos geogênicos próximo aos sambaquis Carniça I e Carniça III.

Tabela 11 - Freqüência média (\%) de minerais pesados transparentes não micáceos, por agrupamento de amostras.

Tabela 12 - Tipos de grãos identificados sob lupa binocular e agrupados por afinidade descritiva de textura e/ou constituição. 


\section{Figuras}

Figura 1 - Mapa dos sistemas deposicionais da região entre Jaguaruna e Imbituba, SC, com a localização dos sambaquis estudados nesta Dissertação (em vermelho). Modificado de Giannini et al. (2007).

Figura 2 - Localização do sítio Jabuticabeira II (em amarelo) em relação aos sistemas deposicionais locais. Modificado de Giannini (1993).

Figura 3 - Visão panorâmica de parede exposta do lócus 2 do sambaqui Jabuticabeira II

Figura 4 - Aspecto geral (A) e de detalhe (B) do sambaqui Encantada III, visto a partir

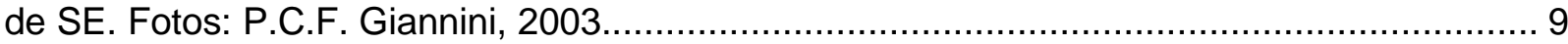

Figura 5 - Aspecto geral (A) e de detalhe (B) do sambaqui Carniça III. 10

Figura 6 - Exemplo de representação estilizada, em seção colunar e perfis (ciclos granocrescentes e granodecrescentes na forma de triângulos), de composição de fácies originalmente expostas em diversos afloramentos. Compilado de Rossetti et al. (2004).......21

Figura 7 - Exemplo de uso do conceito de associações de fácies, em depósitos de planície de maré, como recurso para a interpretação do local de deposição. Modificado de Holland (2008).

Figura 8 - Esquema de hierarquização das superfícies delimitantes de elementos arquitetônicos. Os números no interior dos círculos indicam a hierarquia da superfície. Compilado de Ferreira Junior e Castro (2001).

Figura 9 - Exemplo de classificação de fácies por Stein et al. (1992), aplicada à litologia da unidade 308/304 do sambaqui British Camp, em San Juan Island, Washington, EUA. Gravel $=$ cascalho. Matrix $=$ areia, silte e argila. Shell $=$ conchas. Rock $=$ rocha. Few $=<25 \%$. Many $=>25 \%$. Brok $=$ quebrada. Whol $=$ inteira. Ang $=$ anguloso. Round $=$ arredondada... .27

Figura 10 - Exemplo hipotético de situação arqueológica que requer uso da micromorfologia, demandado por questões específicas. (a) Valas circulares e alongadas com preenchimento de solo incomum e artefatos, sugerindo estruturas funerárias, em sítio a céu aberto. Questionamentos: qual a origem do material de preenchimento das valas e qual o ritmo de deposição? (os retângulos indicam locais de amostragem). (b) Seqüência de abrigo composto por quatro estratos arqueológicos de fácies distintas. A camada 2 apresenta lentes difusas com cinzas (3), interpretadas como estruturas de combustão pouco ordenadas. Questionamentos: qual o modo e as condições deposicionais específicos para cada fase de ocupação e quais as funções das estruturas de combustão? Modificado de Courty (2001). ..35

Figura 11 - Exemplo de peds em microestrutura de blocos subangulares "muito separados". Notar planos de acomodação (v) entre os peds, revestimentos de argila interpedal (cc) e nódulos difusos de hidróxido de Mn intrapedais (n). Horizonte argílico. Polarizadores paralelos. Fotomicrografia de Stoops (2003). .36

Figura 12 - Exemplo de revestimento do tipo capa ligante (linking cap) ou geopetal (Ic) formada por calcita. Observam-se vazios (v) e grãos de quartzo (Q). Polarizadores paralelos. Fotomicrografia de Stoops (2003).

Figura 13 - Exemplo de nódulo órtico de calcita $(\mathrm{Ca})$ em meio a massa basal cinza amarelado (gm). Polarizadores paralelos. Fotomicrografia de Stoops (2003).

Figura 14 - Exemplo de preenchimento de canal por excrementos elipsóides (e) compostos por calcita micrítica e argila. Polarizadores paralelos. Fotomicrografia de Stoops (2003). 
Figura 15 - Exemplo de pelotilhas ou pellets em contexto sedimentar (pelotilhas clásticas). Calciarenito "peletoidal" de cimento calcítico. Notar semelhança com o exemplo pedográfico da figura 5. Polarizadores paralelos. Fotomicrografia de Carozzi (1993). 37

Figura 16 - Exemplos de cutículas de clorita (com cimento calcítico intersticial em A), formadas sob condições diagenéticas em quartzo arenito. Em pedografia, este tipo de feição seria designado revestimento (Stoops, 2003) ou cutan (Brewer, 1976). Fotomicrografia de Carozzi (1993).

Figura 17 - Exemplo de túbulo preenchido parcialmente por cristais neoformados pseudoespáticos de dolomita. Se esta feição ocorresse em solo, seria denominada como preenchimento denso incompleto, de acordo com Stoops (2003: p. 114). Fotomicrografia de Carozzi (1993). 38

Figura 18 - Exemplos de estratos. (A) Estrato tabular formado por seixos, possível de ser individualizado, mesmo com pouca variação composicional; notar gradação interna inversa-normal. (B) Depósitos de canal fluvial (Período Carbonífero, noroeste da Alemanha) mostrando estratos tabulares inclinados com mergulho para a esquerda. Fotos retiradas de Walker (2006), que utilizou originalmente o termo estrato (stratum). 45

Figura 19 - Localização dos lócus 1 e 2 de levantamento arqueológico (MAE-USP), em planta planialtimétrica no sambaqui Jabuticabeira II. Modificado de Villagrán (2008). 46

Figura 20 - Amostragem de sedimentos indeformados (caixas de metal) e deformados (retirados com espátula, no arredor de cada caixa) nas recorrências das lâminas "funerárias" (fácies Lc) do sambaqui Jabuticabeira II, lócus 2. Amostras indicadas na foto: JB-01TP, JB02TP e JB-03TP (Tabela 4). Seção vertical (antiga frente de lavra, exumada) com orientação $\mathrm{N} 80^{\circ}$.

Figura 21 - Amostragem de sedimentos indeformados (caixas de metal) e deformados (retirados com espátula no arredor de cada caixa) nas recorrências das lâminas "funerárias" (fácies Lc) do sambaqui Jabuticabeira II, lócus 2. Amostras indicadas na foto: JB-04TP e JB05TP (Tabela 4). Seção vertical (antiga frente de lavra, exumada) com orientação $N 80^{\circ}, 1 \mathrm{~m}$ a $W$ do local da figura anterior. 48

Figura 22 - Amostragem de sedimento indeformado (caixa de metal) e deformado (retirado com espátula, junto a caixa) em recorrência da lâmina "funerária" (fácies Lc) do sambaqui Jabuticabeira II, lócus 1. Amostra indicada na foto: JB-06TP (Tabela 4). Seção

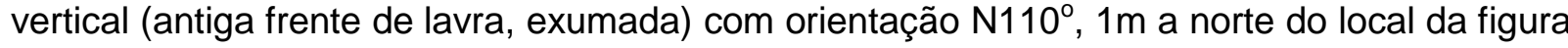
anterior.

Figura 23 - Amostragem de sedimentos indeformados (caixas de metal) e deformados (cavidades ao lado das caixas) em sucessão vertical contínua, na camada superior de "terra preta" (fácies LA) do sambaqui Jabuticabeira II, lócus 1. Amostras indicadas na foto: JB-07TP a JB-17TP (Tabela 4). Seção vertical (antiga frente de lavra, exumada) com orientação $\mathrm{N} 110^{\circ}$

Figura 24 - Localização das trincheiras próximas ao sambaqui Jabuticabeira II. Quadrículas em coordenadas UTM com intervalo de 50 m. Imagem Landsat, 2006. 50

Figura 25 - Mosaico de fotos aéreas com a localização da trincheira GS03 e vala de carcinicultura GS-01, próximo do sambaqui Encantada III. Foto aérea de 1977/78. 51

Figura 26 - Localização dos sambaquis Carniça I a IV e Canto da Lagoa, e a trincheira CV-01, em relação à planície de cordões de Campos Verdes. 53

Figura 27 - Diagrama para semiquantificação por estimativa visual. Modificado de Terry e Chilingar (1955) apud May et al. (2002). 64

Figura 28 - Esquema de contagem de número de grãos e número de contatos grãogrão que cruzam o retículo (linha horizontal). Nesta figura, o retículo corta nove grãos e 
apenas um contato grão-grão; portanto, a proximidade de empacotamento é $1 / 9 \times 100=$ $11,11 \%$, de acordo com a fórmula 2. Modificado de Kahn (1956).

Figura 29 - Esquema de um diagrama em caixa (boxplot), ferramenta de estatística descritiva utilizado neste trabalho.

Figura 30 - Localização das seções colunares (A e B) levantadas para o lócus 1 do sambaqui Jabuticabeira II. Ver seções colunares A e B nas Figuras 31 e 32, respectivamente.

Figura 31 - Seção colunar de parte da seção exposta no lócus 1, do sambaqui Jabuticabeira II. Correspondente à coluna $\mathrm{A}$ da Figura 30.

Figura 32 - Seção colunar de parte da seção exposta no lócus 1, do sambaqui Jabuticabeira II. Correspondente à coluna $\mathrm{B}$ da Figura 30.

Figura 33 - Localização da seção colunar L2 de parte da seção exposta no lócus 2, do sambaqui Jabuticabeira II.Ver seção colunar L2 na Figura 34. 82

Figura 34 - Seção colunar (L2) de parte da seção exposta do lócus 2, do sambaqui Jabuticabeira II. As idades assinaladas em vermelho, à esquerda da seção, foram retiradas de Bendazzoli (2007) e calibradas conforme descrito no final do item 4.2.8.

Figura 35 - Seção colunar da trincheira (JB-01) em sedimento geogênico, 60m a NE do sambaqui Jabuticabeira II (Figura 24).

Figura 36 - Trincheira (JB-01) em sedimento geogênico, 60m a NE do sambaqui Jabuticabeira II. Em amarelo, os códigos de amostragem de cada fácies (JB-01 a e $\beta$ ).......85

Figura 37 - Seção colunar de trincheira (JB-02) em sedimento geogênico, 70m a NE do sambaqui Jabuticabeira II (Figura 24).

Figura 38 - Trincheira (JB-02) em sedimento geogênico, 70m a NE do sambaqui Jabuticabeira II. Em amarelo, os códigos de amostragem de cada fácies (JB-02 a e $\beta$ ).......86

Figura 39 - Seção colunar de trincheira (JB-03) em sedimento geogênico, aproximadamente $80 \mathrm{~m}$ a NE do sambaqui Jabuticabeira II (Figura 24). .86

Figura 40 - Trincheira (JB-03) em sedimento geogênico, aproximadamente 80m a NE do sambaqui Jabuticabeira II. Em amarelo, os códigos de amostragem de cada fácies (JB-03 $\alpha$ e $\beta$ ). 86

Figura 41 - Seção colunar de trincheira (JB-04) em sedimento geogênico, 90m a NE do sambaqui Jabuticabeira II (Figura 24).

Figura 42 - Seção colunar de trincheira (JB-05) em sedimento geogênico, aproximadamente $200 \mathrm{~m}$ a NE do sambaqui Jabuticabeira II (Figura 24). Notar estruturas de impregnação (sensu Yaalon \& Fränzle, 1975) e marcas de raízes na fácies arenosa.

Figura 43 - Trincheira (JB-05) em sedimento geogênico paleolagunar, distante 200 a 250m do sambaqui Jabuticabeira II. Em amarelo, os códigos de amostragem de cada fácies (JB-05 $\alpha$ e $\beta$ ).

Figura 44 - Exposição em trincheira aberta na porção mais alta do sambaqui Encantada III. Estão representados em preto/amarelo os códigos de amostragem. Foto: Paulo C. F. Giannini.

Figura 45 - Seção colunar e descrição de fácies na trincheira GS03, em sedimentos geogênicos, aproximadamente $900 \mathrm{~m}$ a NW do sambaqui Encantada III (Figura 25). A exposição descrita na vala de carcinicultura (GS-01), distante aproximadamente 50m do sambaqui Encantada III, possui configuração estratigráfica muito semelhante à desta trincheira. 
Figura 46 - Trincheira GS03 em sedimentos geogênicos, aproximadamente 900m a NW do sambaqui Encantada III. Em amarelo, indicação dos códigos de amostragem (GS-03 $\alpha, \beta, \gamma$ e $\delta)$.

Figura 47 - Seção colunar e descrição de fácies de trincheira no sambaqui Carniça III (Figura 26)

Figura 48 - Trincheira no topo do sambaqui Carniça III.

Figura 49 - Seção colunar em trincheira (CV-01), aproximadamente 10m a SW do sambaqui Carniça I. 93

Figura 50 - Trincheira (CV-01) em sedimentos geogênicos, aproximadamente 10m a SW do sambaqui Carniça I. Em amarelo, os códigos referentes às amostras coletadas....... 93

Figura 51 - Gráficos tipo boxplot das quantidades de matéria orgânica total e teor de carbonatos. As cores representam localidades. Geo - sedimento geogênico, oriundo de trincheira e poços. TP - "terra preta" e "funerária", oriundo de camada e lâminas carbonosas de sambaqui. Areia - sedimento de camada predominantemente arenosa de sambaqui. Concha - sedimento bioclástico de sambaqui.

Figura 52 - Gráficos tipo boxplot das frações de areia. As cores representam localidades. Geo - sedimento geogênico, oriundo de trincheira e poços. TP - "terra preta" e "funerária", oriundo de camada e lâminas carbonosas de sambaqui. Areia - sedimento de camada predominantemente arenosa de sambaqui. Concha - sedimento bioclástico de sambaqui.....

Figura 53 - Gráficos tipo boxplot dos parâmetros estatísticos da granulometria. As cores representam localidades. Geo - sedimento geogênico, oriundo de trincheira e poços. TP - "terra preta" e "funerárias", oriundo de camada e lâminas carbonosas de sambaqui. Areia - sedimento de camada predominantemente arenosa de sambaqui. Concha sedimento bioclástico de sambaqui. 100

Figura 54 - Diagrama de dispersão dos parâmetros granulométricos diâmetro médio e desvio padrão para amostras da região do sítio Jabuticabeira II. Os dados referentes às dunas eólicas de diferentes gerações (G1, G2 e G3) foram retirados de Giannini (1993), com as seguintes áreas de abrangência: G1 - entre rio Riachinho e rio Sangão; G2 - entre a lagoa do Figueirinha e a margem sudoeste da laguna Garopaba do Sul; G3 - entre as ponta da Galheta e da Ilhota. Isto está muito estranho. 101

Figura 55 - Diagrama de dispersão dos parâmetros granulométricos assimetria e desvio padrão para amostras da região do Jabuticabeira II. Os dados referentes as dunas eólicas de diferentes gerações (G1, G2 e G3) foram retiradas de Giannini (1993), onde G1 - entre rio Riachinho e rio Sangão; G2 - entre a lagoa do Figueirinha e a margem sudoeste da laguna Garopaba do Sul; G3 - entre a ponta da Galheta e ponta da Ilhota.

Figura 56 - Diagrama de dispersão dos parâmetros granulométricos diâmetro médio e desvio padrão para amostras da região dos sítios Carniça III e Encantada III. Os dados referentes as dunas eólicas da geração 3 (G3) foram retirados de Giannini (1993), relativos à região compreendida entre as pontas da Galheta e da llhota. Os dados referentes a cordões litorâneos e dunas eólicas de Campos Verdes foram extraídos de Tanaka (2007)..... 103

Figura 57 - Diagrama de dispersão dos parâmetros granulométricos desvio padrão e assimetria, para amostras da região dos sítios Carniça III e Encantada III. Os dados referentes as dunas eólicas da geração 3 (G3) foram retirados de Giannini (1993), relativos à região compreendida entre as pontas da Galheta e da Ilhota. Os dados referentes a cordões litorâneos e dunas eólicas de Campos Verdes foram extraídos de Tanaka (2007)...... 103 
Figura 58 - Gráficos tipo boxplot dos índices de estabilidade química de minerais pesados. iZTR: soma das porcentagens de minerais ultraestáveis; iMET: soma das porcentagens de minerais metaestáveis e iINS: soma das porcentagens de minerais instáveis. As cores representam localidades. Geo - sedimento geogênico, oriundo de trincheira e poços. TP - "terra preta" e "funerárias", oriundo de camada e lâminas carbonosas de sambaqui. Areia - sedimento de camada predominantemente arenosa de sambaqui. Concha - sedimento bioclástico de sambaqui. 106

Figura 59 - Fotomicrografias de agregados lamíticos ricos em diatomáceas (a e b), componente do grupo "fragmentos siliciclásticos", de escória vítrea (b), componente do grupo "produtos de combustão", e de grãos de quartzo cimentados por fosfato (b), componente do grupo "crosta fosfática". Os agregados lamíticos com diatomáceas assemelham-se à fácies argilosa cinza clara, rica em diatomáceas descrita por Amaral (2009). Amostras JB-12-TP (a) e JB-02-TP (b)

Figura 60 - Fotomicrografias de fragmentos de concha com incrustação fosfática (a e b), componente do grupo "crostas fosfáticas". Amostra JB-06-TP. 109

Figura 61 - Fotomicrografias de ossos em diferentes graus de alteração térmica, do grupo "produtos de combustão". O fragmento do canto superior à direita (em a) foi considerado como "osso marrom" e, portanto, não alterado termicamente (a) e os de b, fragmentos de ossos calcinados. Amostras JB-01-TP (a) e JB-04-TP (b) 110

Figura 62 - Distribuição em barra dos resultados da análise da fração grossa das amostras do lócus 1 do sambaqui Jabuticabeira II, representados pelos códigos de fácies e expressos em \% de cada grupo (cores da legenda). As setas indicam aumento ascendente da quantidade dos componentes "produtos de combustão" (seta vermelha) e "fragmentos siliciclásticos" (seta preta). Localização das amostras nas Figura 31 e Figura 32.

Figura 63 - Distribuição em barra dos resultados da análise da fração grossa das amostras do lócus 2 do sambaqui Jabuticabeira II, representados pelos códigos de fácies e expressos em \% por grupo textutal-mineralógico (cores da legenda). Localização das amostras na Figura 34

Figura 64 - Distribuição em coluna dos resultados da análise da fração grossa das amostras referente às fácies ricas em produtos de combustão do sambaqui Jabuticabeira II, expressos em \% por grupo textural-mineralógico (cores da legenda). 113

Figura 65 - Distribuição em barra dos resultados da análise da fração grossa das amostras dos sedimentos geogênicos do entorno do sambaqui Jabuticabeira II, representados pelos códigos de fácies e expressos em \% por grupo textural-mineralógico (cores da legenda). As amostras JB-04- $\alpha$ e $\beta$ possuem aproximadamente entre 20 e $40 \%$ de fragmentos vegetais que não foram ilustrados no gráfico; por este motivo, não fecham em 100\% Localização dos pontos amostrados na Figura 24. 114

Figura 66 - Distribuição em barra dos resultados da análise da fração grossa das amostras dos sedimentos do sambaqui Encantada III (GS-TP e GS-areia) bem como dos sedimentos geogênicos do entorno (GS-01), expressos em \% por grupo textural-mineralógico (cores da legenda). A amostra GS-01 possui aproximadamente 10\% de fragmentos vegetais que não foram ilustrados no gráfico; por este motivo, não fecha em 100\%. Localização dos pontos amostrados na Figura 25.

Figura 67 - Distribuição em barra dos resultados da análise da fração grossa das amostras dos sedimentos do sambaqui Encantada III (CV-TP e CV-areia) bem como dos sedimentos geogênicos do entorno (CV-01- $\alpha$ a $\delta$ ), expressos em \% por grupo texturalmineralógico (cores da legenda). A amostra CV-01- $\delta$ possui aproximadamente $60 \%$ de fragmentos vegetais que não foram ilustrados no gráfico, por este motivo, não fecha em 100\%. Localização dos pontos amostrados na Figura 26. 
Figura 68 - Diagrama de dispersão dos grupos "fragmentos siliciclásticos" e "bioclastos fragmentados" separados por fácies "funerárias" e "terra preta" (Lc e LA) e "conchíferas" (A $\ell$, $\mathrm{Cb}, \mathrm{CLb}, \mathrm{Cl}, \mathrm{CA} \ell$ e Ap) do sambaqui Jabuticabeira II. Para a reta de regressão preta (LA), $\alpha=0,01$; para a reta vermelha (Lc), $\alpha<0,025$; para a reta amarela (f́cies conchíferas), $\alpha<0,2$.

Figura 69 - Diagrama de dispersão dos grupos "crostas fosfáticas" e "osso marrom" separados por lâminas "funerárias" e "terra preta" (Lc e LA) e "conchíferas" (A $\ell, C b, C L b, C \ell$, CAl e Ap) do sambaqui Jabuticabeira II. Para a reta de regressão preta (LA) $=0,3$; para a reta vermelha (Lc), $\alpha=0,2$; para a reta amarela (fácies conchíferas), $\alpha<0,025$.

Figura 70 - Diagrama de dispersão dos grupos "produtos de combustão" e "ossos marrons" separados por lâminas "funerárias" e "terra preta" (Lc e LA) e "conchíferas" (Al, Cb, $\mathrm{CLb}, \mathrm{C} \boldsymbol{\ell}, \mathrm{CA} \boldsymbol{\ell}$ e Ap) do sambaqui Jabuticabeira II. Para a reta de regressão preta (LA), $\alpha$ (nível de significância) $=0,3$; para a reta vermelha $(\mathfrak{k}$ ) 3 ; ; para a reta amarelác(f́s conchíferas), $\alpha<0,2$.

Figura 71 - Fotomicrografia de fragmento de concha carbonática totalmente envolvido por revestimento fosfático (isótropo na foto b). Polarizadores paralelos (PPL) (a),

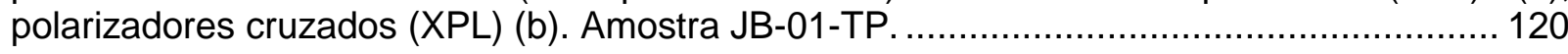

Figura 72 - Fotomicrografia de fragmento de osso totalmente envolvido por revestimento fosfático (isótropo, em b). Notar que o fragmento de osso possui fraca birrefringência (b). Polarizadores paralelos (PPL) (a), polarizadores cruzados (XPL) (b). Amostra JB-06-TP

Figura 73 - Fotomicrografia de grãos de quartzo parcial a totalmente envolvidos por revestimento fosfático (a), semelhante ao fragmento da Figura 59a, e envolvendo totalmente um fragmento de carvão (b). Notar que os poros do carvão também se encontram preenchidos por fosfato. a e b: PPL. Topo para cima (a) e para canto superior esquerdo (b). Amostras JB-12-TP (a) e JB-06-TP (b).

Figura 74 - Fotomicrografia de fragmento fosfático envolvido por micromassa amarronzada, denotando o carácter alóctone deste fragmento no depósito estudado. PPL (a), XPL (b). Amostra JB-12-TP. Notar que a birrefringência no centro do fragmento, em b, indica a textura botrioidal. 121

Figura 75 - Fotomicrografias de osso de cor azulada (a) e birrefringência semelhante a da apatita mineral (b). Estas características ópticas são compatíveis com ossos submetidos à alta temperatura. PPL (a), XPL (b). Amostra JB-15-TP. 122

Figura 76 - Fotomicrografia de tecido vegetal deformado termicamente. PPL. Amostra JB-06-TP. 122

Figura 77 - Fotomicrografias de escória vítrea englobando grãos de quartzo. Nota-se que o quartzo se apresenta íntegro, indicando fusão de sílica sob temperatura inferior ao ponto de fusão do mineral. PPL (a), XPL (b). Amostra JB-07-TP.

Figura 78 - Fotomicrografias de fragmento de carvão com impregnação fosfática marrom alaranjada (a) e fragmento de lamito contendo grande número de diatomáceas (b), semelhante ao agregado lamítico da Figura 59. PPL. Amostras JB-13-TP (a) e JB-06-TP (b).

Figura 79 - Fotomicrografias de fragmento de calcedônia fibrorradiada, interpretado como provável estilha. PPL (a) e XPL (b). Amostra JB-12-TP.

Figura 80 - Fotomicrografias de agregado em arranjo radial, composto predominantemente por provável clorita (b). PPL (a) e XPL (b). Amostra JB-04-TP............ 124 
Figura 81 - Fotomicrografias de nódulos disórtico (a) e anórtico com cimentação fosfática (b). PPL. Amostra JB-13-TP (a) e, amostra JB-16-TP (b). ..............................124

Figura 82 - Fotomicrografias de fragmento de rocha basáltica. PPL (a) e XPL (b).

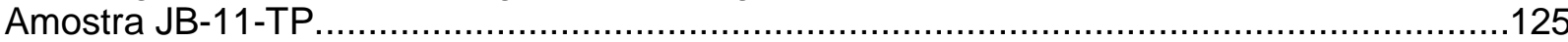

Figura 83 - Fotomicrografia de tessitura b salpicada. Os grãos brancos maiores são de quartzo. XPL. Amostra JB-12-TP.

Figura 84 - Fotomicrografia de fragmento vegetal carbonizado contendo carbonato (calcimicrita), provavelmente formado a partir de oxalato de cálcio vegetal calcinado. Amostra JB-06-TP.

Figura 85 - Fotomicrografias de fragmento vegetal termicamente alterado, restando apenas agregados circulares de calcimicrita (arredondados e birrefringentes), em substituição aos esferulitos de oxalato de cálcio de origem vegetal (b). PPL (a) e XPL (b). Amostra JB-07TP. 126

Figura 86 - Fotomicrografias de fragmento fosfático contendo esferulitos (b). Esta feição é correlacionável a coprólitos humanos (Paul Goldberg, comunicação pessoal). PPL (a) e XPL (b). Amostra JB-13-TP.

Figura 87 - Fotomicrografia de laminação fosfática (linhas mais finas alaranjadas em a), microestrutura atribuída ao pisoteamento de material rico em $\mathrm{P}$, como esterco (Courty et al, 1989; Shahack-Gross \& Finkelstein, 2008) ou outro material protéico decomposto. Foto sob lupa ilustrando lente quartzo arenosa sem matriz (mónica, em b). PPL. Amostra JB-06-TP.

Figura 88 - Imagem digitalizada com scanner diretamente de lâmina, ilustrando canal transpedal com acumulação de micromassa nas bordas (setas amarelas). PPL. Amostra JB poço.......

Figura 89 - Variação do índice de proximidade de empacotamento na horizontal (azul) e na vertical (vermelho). As setas indicam as tendências de variação dos dados obtidos. Lócus $1(A)$ e lócus $2(B)$. 130

Figura 90 - Variação da porosidade medida em um quadro (vermelho) e a média de 28 quadros (azul). As setas indicam as tendências de variação dos dados obtidos. Lócus 1 (A), lócus 2 (B).

Figura 91 - Microfragmentos fosfáticos em dois formatos distintos: placóide a tabular, à esquerda, e globular, à direita. Amostra de torrão da "terra preta", fácies LA (JB-17-TP)....132

Figura 92 - Detalhe do fragmento globular da figura anterior, mostrando a característica morfológica frambóide do fosfato. Nota-se que o formato globular é repetido em miniatura na superfície do esferóide maior. Amostra de torrão, da "terra preta" da fácies LA (JB-17-TP). 133

Figura 93 - Detalhe do fragmento placóide da Figura 91, mostrando a característica morfológica frambóide do fosfato, semelhante a colônias de microorganismos cocoidais. Notam-se cavidades (centro), semelhantes às interpretadas por Gilinskaya et al (2007):58 como sítios abandonados por bactérias após a formação do envelope mineral. Amostra de torrão, da "terra preta" da fácies LA (JB-17-TP). 133

Figura 94 - Revestimento fosfático sobre concha. Notar textura botrioidal. Amostra de concha (provável Anomalocardia brasiliana) com incrustação marrom alaranjada de fosfato, selecionada aleatoriamente durante análise da fração grossa. Amostra proveniente do sambaqui Jabuticabeira II. 
Figura 95 - Detalhe da imagem anterior, sobre um dos glóbulos fosfáticos. Notar rugosidade de superfície. Amostra de concha (provável Anomalocardia brasiliana) com incrustação marrom alaranjada de fosfato, selecionada aleatoriamente durante análise da fração grossa, proveniente do sambaqui Jabuticabeira II. 134

Figura 96 - Detalhe da Figura 94, sobre um dos glóbulos fosfáticos. Notar que a rugosidade de superfície corresponde a placas de minerais fosfáticos (canto inferior esquerdo) em trama predominantemente ortogonal à superfície do glóbulo. No canto superior direito, nota-se um fragmento de provável diatomácea. Amostra de concha (provável Anomalocardia brasiliana) com incrustação marrom alaranjada de fosfato, selecionada aleatoriamente durante análise da fração grossa, proveniente do sambaqui Jabuticabeira II.

Figura 97 - Aspecto esponjoso de escória silicosa, formado pela coalescência de bolhas gasosas. Amostra de escória proveniente do sambaqui Jabuticabeira II, selecionada aleatoriamente durante análise da fração grossa. 136

Figura 98 - Detalhe da figura anterior, mostrando a textura circular e lisa do interior das bolhas. Amostra de escória proveniente do sambaqui Jabuticabeira II, selecionada aleatoriamente durante análise da fração grossa. 136

Figura 99 - EDS da amostra ilustrada na imagem anterior, indicando presença de Si, $\mathrm{Ca}, \mathrm{Al}, \mathrm{Na}, \mathrm{K}$ e Mg. 136

Figura 100 - Abundância de fragmentos de diatomáceas, exemplificados nas setas vermelhas, em meio a folhas de argilominerais aparentemente clásticos. Amostra de agregado lamítico proveniente do sambaqui Jabuticabeira II, selecionada aleatoriamente durante análise da fração grossa.

Figura 101 - Detalhe de diatomácea parcialmente preservada em meio a folhas de argilominerais com forma plana irregular. Amostra de agregado lamítico proveniente do sambaqui Jabuticabeira II, selecionada aleatoriamente durante análise da fração grossa. . 138

Figura 102 - Mapeamento elementar de Ca (pontículos pretos), sem (a) e com (b) sobreposição na imagem de elétrons retroespalhados. Notar abundância de Ca tanto na micromassa quanto nos fragmentos de concha de molusco no centro das imagens. Amostra em seção delgada JB-04-TP, lócus 2, Jabuticabeira II.

Figura 103 - Mapeamento elementar de P (pontículos vermelhos), sem (a) e com (b) sobreposição na imagem de elétrons retroespalhados. Notar que o $\mathrm{P}$ encontra-se restrito aos fragmentos de ossos, com pouca expressão na micromassa. Amostra em seção delgada JB04-TP, lócus 2, Jabuticabeira II.

Figura 104 - Mapeamento elementar por presença. Imagem de elétrons retroespalhados (a) e mapeamento elementar por presença de Al (b: pontículos verdes). Os agrupamentos de pontículos verdes na imagem b) delineam fragmentos de material rico em filossilicatos, classificado como "lamito". Amostra em seção delgada JB-09-TP, lócus 1, Jabuticabeira II.

Figura 105 - Mapeamento elementar de P (pontículos vermelhos) (a), e mapeamento por presença de $\mathrm{Ca}(\mathrm{b})$. Notar que tanto o $\mathrm{P}$ e o $\mathrm{Ca}$ encontram-se restritos aos fragmentos de ossos, com pouca expressão na micromassa. Mesma imagem que a Figura 104a. Amostra em seção delgada JB-09-TP, lócus 1, Jabuticabeira II 140

Figura 106 - Mapeamento elementar por presença de Si (pontículos magenta). Notar que além dos grãos de quartzo, a presença de Si na matriz é expressiva, comportamento oposto ao de $\mathrm{P}$ e Ca (figuras anteriores). Mesma imagem que a Figura 104a. Amostra em seção delgada JB-09-TP, lócus 1, Jabuticabeira II. 
Figura 107 - Mapeamento elementar por presença. Imagem de elétrons retroespalhados (a) e mapeamento elementar por presença de Al (b: pontículos verdes). Os agrupamentos de pontículos verdes na figura $b$ delineam fragmentos de material rico em filossilicatos, designado como "lamito" (canto superior esquerdo) e, no centro da imagem, presença de Al delineando discretamente um fragmento de escória vítrea. Amostra em seção delgada JB-09-TP, lócus 1, Jabuticabeira II.

Figura 108 - Mapeamento elementar por presença de Si (pontículos magenta) (a), e de $\mathrm{K}$ (b) (pontículos marrons). Notar que o Si possui presença importante tanto na micromassa quanto nos elementos do arcabouço, inclusive na escória vítrea (no centro da imagem a). Já o K possui comportamento semelhante ao Al (Figura 107b). Amostra em seção delgada JB09-TP, lócus 1, Jabuticabeira II.

Figura 109 - Mapeamento elementar por presença de P (a) (pontículos vermelhos) e $\mathrm{Ca}$ (b) (pontículos pretos). Notar que ambos os padrões de distribuição elementar concentram-se nos elementos do arcabouço e possuem distribuição muito distinta em relação ao Si (Figura 108a). Mesma imagem que a Figura 107a. Amostra em seção delgada JB-09TP, lócus 1, Jabuticabeira II.

Figura 110 - Variação de $\delta^{13} \mathrm{C}(13 \mathrm{C} / 12 \mathrm{C})$, em \%o (per mille), nas lâminas "funerárias" recorrentes (fácies Lc) do lócus 2 (gráfico superior) e do lócus 1 (gráfico inferior) do sambaqui Jabuticabeira II. .144

Figura 111 - Variação deð ${ }^{13} \mathrm{C}(13 \mathrm{C} / 12 \mathrm{C})$, em \%o (per mille), de sedimentos paleolagunares (fácies areno-lamosa) da área contígua ao sambaqui Jabuticabeira II, com localização apontada na Figura 24.

Figura 112 - Correlação linear entre valores de carbono orgânico total (COT) e nitrogênio total ( $\mathrm{N}$ total) validada pelo nível de significâncciłteste $t$ de Student); $n=26$ corresponde ao espaço amostral.

Figura 113 - Distribuição dos valores de ${ }^{13} \mathrm{C}$ em \%o (per mille) $(13 \mathrm{C} / 12 \mathrm{C})$ e da razão carbono orgânico/nitrogênio total $\left(\mathrm{C}_{\text {org }} / \mathrm{N}_{\text {total }}\right)$ para a determinação da origem da matéria orgânica, utilizando os intervalos típicos de ambientes costeiros (polígonos com cores variadas) segundo Lamb et al. 2006. COP-D: carbono orgânico particulado de água doce; COP-M: carbono orgânico particulado marinho; C4: plantas de caminho metabólico tipo C4, geralmente associado a gramíneas; C3: plantas de caminho metabólico tipo C3, geralmente associado a elementos arbóreos. 146

Figura 114 - Distribuição dos valores de ${ }^{13} \mathrm{C}(13 \mathrm{C} / 12 \mathrm{C})$ e $\delta^{15} \mathrm{~N}(15 \mathrm{~N} / 14 \mathrm{~N})$, expressos em \% (per mille), obtidos em matéria orgânica das fácies Lc e LA ("funerárias" e "terra preta") (TP), dos sambaquis, e de sedimentos geogênicos identificados por "Geo". Campos de origem da matéria orgânica delimitados segundo White (2001).

Figura 115 - Compilação de valores de $\delta^{15} \mathrm{~N}$ da literatura (quadro), modificado de Fogg et al (2005), onde se observa que grande parte dos valores acima de 10 \% correpondem a dejetos animais (animal waste) e fossas sépticas (septic). Fertilizer $=$ fertilizantes manufaturados e Natural = matéria orgânica de solo "natural". 148

Figura 116 - Localização da trincheira amostrada na paleolaguna Garopaba do Sul (JB03) para datação ${ }^{14} \mathrm{C}$ em valvas de Anomalocardia brasiliana (imagem superior) e coluna estratigráfica desta trincheira (imagem inferior), com indicação da idade calibrada em vermelho. 150

Figura 117 - Curvas de variação do NRM para a costa brasileira, baseadas em datações de carapaças fósseis de vermitídeos. A curva pontilhada, assim como os símbolos quadrados vazados, são específicos para o litoral sul de Santa Catarina. Compilado por Angulo et al. (2006). 
Figura 118 - Localização da trincheira amostrada (marcador vermelho) para datação 14C em valvas inteiras e preservadas de Anomalocardia brasiliana na imagem à esquerda e, coluna estratigráfica desta trincheira com a idade calibrada indicada em vermelho (2486-2881 anos AP) à direita

Figura 119 - Gráfico de intervalo das idades obtidas para conchas dos sambaquis Jabuticabeira II e Carniça I (Carniça 1 e 1A), compilado de DeBlasis et al (2005) e das conchas de trincheiras próximas a estes sambaquis (JB-03 e CV-01). As idades representadas correspondem ao intervalo médio de várias idades (Carniça 1, $n=5$; Carniça 1A, $n=4$; CV-01, $n=1$; Jabuticabeira II, $n=8$ e JB-03, $n=1$ ) calibradas. 152

Figura 120 - Comparação entre dois diagramas de origem de $\mathrm{MO}\left(\delta^{13} \mathrm{C} \times \mathrm{C} / \mathrm{N}\right)$. Em a, origem da MO do vale do rio Riachinho, testemunho RIA, de Amaral (2008) e em b, origem da MO das amostras deste estudo. Notar semelhança na distribuição dos valores entre os dois gráficos, incluindo as misturas entre marinhas (Algas e COP-M) e plantas C3. Em a, os pontos vazados correspondem à base do testemunho, os em verde à zona intermediária, e os em vermelho ao topo 160

Figura 121 - Diagrama de dispersão entre concentração de fragmentos fosfáticos e \% peso de $\mathrm{N}$ total, separados por fácies Lc ("funerárias") e LA ("terra preta") do sambaqui Jabuticabeira II. Fragmentos no eixo das ordenadas referem-se ao grupo "crostas fosfáticas", obtido por estimativa da fração grossa sob lupa, conforme item 5.5. Para a reta de regressão preta (LA), $\alpha<0,3$; para a reta vermelha (LC), $\alpha<0,05$. 161 


\section{INTRODUÇÃO}

\subsection{O início: concepção e construção do projeto}

A Dissertação que se apresenta está inserida no contexto do projeto temático da Fundação de Amparo à Pesquisa do Estado de São Paulo - FAPESP, intitulado "Sambaquis e Paisagem: Modelando a Inter-relação entre os Processos Formativos Culturais e Naturais no Litoral Sul de Santa Catarina" (Processo 04/11038-0).

Os questionamentos que deram origem às metas, objetivos e métodos desta Dissertação foram desencadeados em uma mesa redonda de brainstorm induzido, onde o orientador, na qualidade de coordenador e participante da sessão, organizou uma série de temas relacionados aos sambaquis e sistemas deposicionais do litoral centro-sul de Santa Catarina.

A autora desta Dissertação escolheu, entre os temas sugeridos pelo coordenador, aquele de sua maior identificação. Na seqüência, todos os participantes foram convidados a elaborar individualmente, e a redigir numa folha de papel, por um período de reflexão silenciosa de cerca de cinco minutos, questões sobre o tema escolhido. Em seguida, cada folha de questões foi passada adiante ao participante ao lado, para servir de inspiração para a formulação de novo conjunto de perguntas, e assim sucessivamente, em sistema de rodízio. Este rodízio de perguntas foi considerado encerrado quando as folhas de questões retornaram ao autor original.

As questões foram então lidas uma por uma, em voz alta, mais uma vez em sistema de rodízio entre os participantes, e classificadas pelo grupo em metas (perguntas do tipo "onde queremos chegar?"), subdivididas em metas de conteúdo e de abordagem, objetivos (perguntas do tipo "o que vamos fazer?"), métodos (perguntas do tipo "como vamos fazer?") e fundamentação bibliográfica.

Além do orientador e da autora desta Dissertação, participaram da sessão de brainstorm o doutorando Daniel Rodrigues do Nascimento Jr, a então candidata ao mestrado Ana Cláudia Machado Ferreira, e dois candidatos à Iniciação Científica, Érico Benedeti Mazini e Ana Paula Burgoa Tanaka, todos com temas de pesquisa ligados ao mesmo projeto. 


\subsection{Sambaquis}

Sambaqui, cujo significado na língua tupi é monte de conchas (tamba = mariscos e $k i=$ amontoado), é a palavra utilizada para designar certos tipos de sítios arqueológicos construídos a partir do acúmulo de conchas durante um período comumente da ordem de centenas ou milhares de anos, por grupos de pescadores-caçadores-coletores (Bendazzoli, 2007; Gaspar, 2002; Prous, 1992 apud Bendazzoli, 2007). Outros termos são encontrados como sinônimos de sambaqui, tais como: "ostreiras" (no Brasil Colônia, segundo relatos portugueses), "kjoekkenmoeddings" ("sobras de alimentos", na Dinamarca) e "kitchenmiddens" ("restos de cozinha", na América do Norte) (Costa, 2005). Tais sítios, principalmente ao longo da costa sul e sudeste brasileira, são construídos a partir do empilhamento de conchas de moluscos (porção volumetricamente mais importante), marinhos ou continentais, entre outros restos de fauna, além de material sedimentar proveniente de depósitos dos sistemas deposicionais naturais situados próximo ou junto aos sítios.

Em relação ao processo construtivo dos sambaquis, Bendazzoli (2007: p 11) menciona três correntes de pensamento arqueológico entre os séculos XIX e XX; a primeira defendia que os sambaquis eram formados por restos de alimentos acumulados ao acaso, sem intencionalidade; a segunda julgava que tais acúmulos eram resultado de processos "naturais" (geológicos); e a terceira entendia que existiam dois tipos de acumulações conchíferas, as ocasionadas por processos "naturais" e as ligadas a processos intencionais de fabricação de monumentos ou marcos, por populações em grau crescente de complexidade social (ver descrição do processo intencional e da monumentalidade em DeBlasis et al., 1998).

Para além do significado arqueológico, os sambaquis adquirem o significado de "marcos geomorfológicos" no contexto da geologia sedimentar, onde têm sido utilizados, através de datações e de nivelamento de sua base, na estimativa e elaboração de curvas de variação do nível relativo do mar (NRM) (Martin et al., 1988). A premissa adotada é que a base do sambaqui encontrava-se emersa e, portanto, acima do NRM no início de sua construção. Giannini et al. (2005) relacionam uma série de advertências a este método de estimativa de NRM. A mais importante delas é que a posição da linha de costa, e não propriamente o NRM, constitui o fator limitante na construção de sambaquis. As mudanças de linha de costa não dependem somente do NRM, mas também do aporte sedimentar, ou, mais precisamente, do balanço entre espaço para acomodação de sedimentos (controlado pelo NRM) e aporte. Além disso, a dinâmica da linha de costa depende de variações em fatores locais no fornecimento sedimentar como, por exemplo, deriva litorânea, abandono e 
retomada de distributários deltaicos, migração de desembocaduras lagunares, compactação de fácies pelíticas e turfáceas sotopostas aos sítios arqueológicos e a própria erosão e retrabalhamento recente dos sambaquis em linhas de costa posteriores à época de construção antrópica.

Independente de seu polêmico significado como marcadores de NRM e linha de costa, os sambaquis representam marcos paisagísticos de valor histórico e científico indiscutível: através do estudo destes monumentos, é possível reconstituir os hábitos e costumes dos povos que viveram no litoral durante grande parte do Holoceno "pré-descobrimento", e suas relações com a evolução do ambiente geológico que os cercava.

\subsection{Contextualização regional: sistemas deposicionais e sambaquis}

A pesquisa proposta nesta Dissertação de Mestrado possui como área maior de interesse a região centro-sul do Estado de Santa Catarina, que, entre aproximadamente 6000 e 1000 anos antes do presente (AP), esteve, segundo DeBlasis et al. (1998) e Gianinni et al. (2005), ocupada pela comunidade sambaquieira, com a edificação de depósitos conchíferos que se incluem entre os maiores do mundo. Datações recentes em sambaquis de ostras, situados no limite interior da planície costeira, permitem elevar a idade máxima da ocupação sambaquieira na região para cerca de 8000 anos AP (DeBlasis et al., comunicação pessoal).

O período durante o qual perdurou esta ocupação é concomitante à formação de maior parte das planícies costeiras holocênicas da região (Giannini et al., 2005), as quais atuaram, portanto, como cenário dinâmico para a construção dos sambaquis.

Neste cenário, entre os municípios de Jaguaruna e Imbituba, Giannini (1993) descreve quatro tipos de sistemas deposicionais: o sistema barra-barreira (ou simplesmente barreira, segundo Giannini et al., 2007), o sistema planície costeira, o sistema lagunar e o sistema eólico (Figura 1). A nomenclatura de sistemas deposicionais adotada por esse autor baseiase na proposta formulada por Fisher \& McGowen (1967), quando da introdução do conceito.

O sistema deposicional barra-barreira (barrier-bar) da região é caracterizado por uma faixa de direção ENE com 0,8 a 2,0 km de largura e mais de $20 \mathrm{~km}$ de comprimento, situada a sul do município de Laguna. Por possuir característica fisiográfica plana, de caráter pouco acidentado (sem encostas), este sistema pode ter constituído terreno favorável ou mesmo preferencial para o assentamento das populações sambaquieiras, haja vista sua grande quantidade relativa de sambaquis (Giannini et al., 2005). Ele é ladeado a oeste pelo sistema lagunar Garopaba do Sul - Camacho - Santa Marta. 


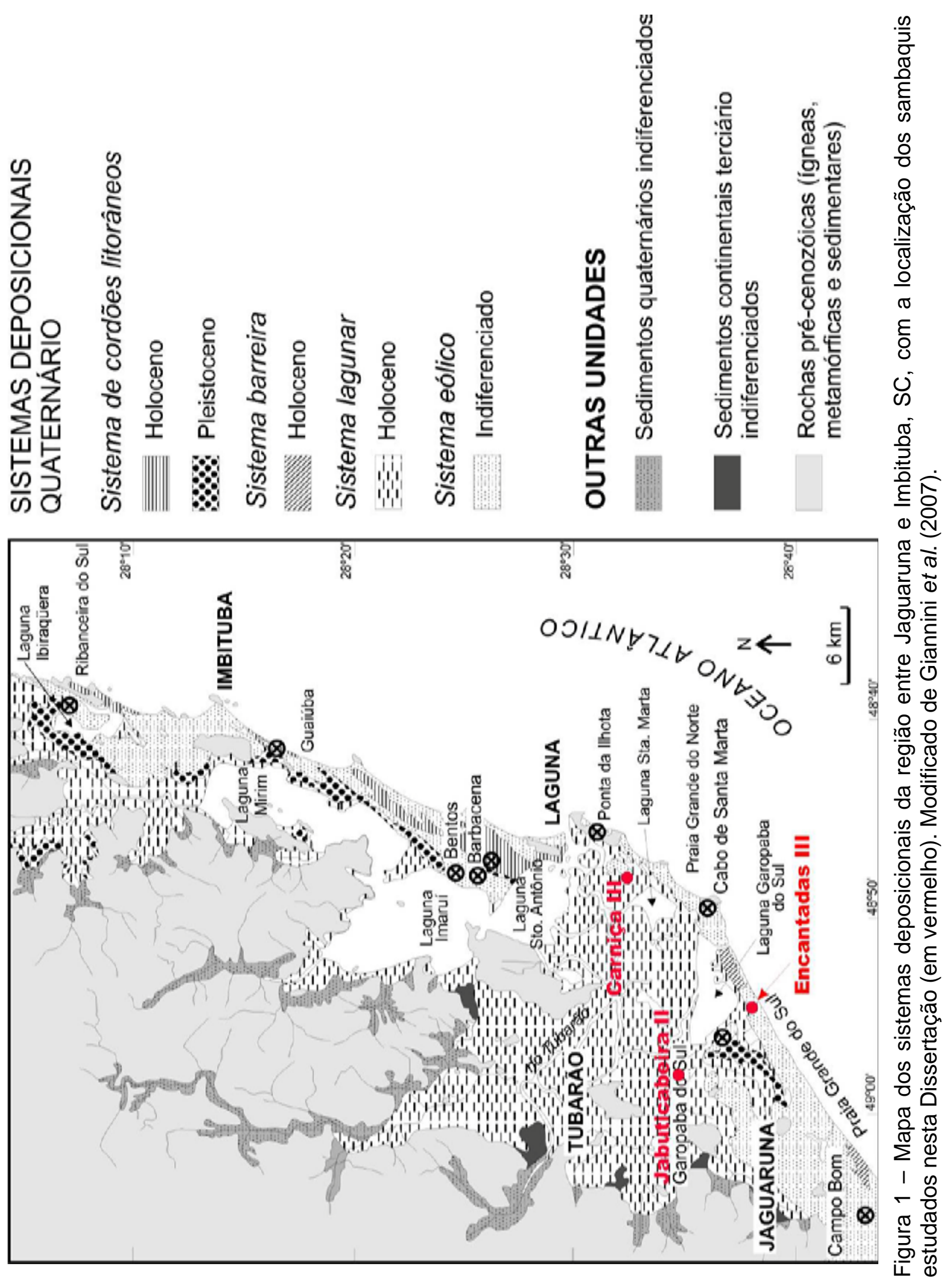


O sistema deposicional planície costeira ou planície de cordões (strandplain) desenvolve-se preferencialmente a norte de Laguna, onde se separa do sistema barrabarreira pela desembocadura lagunar de Entrada da Barra. A planície sedimentar quaternária possui aí até $7 \mathrm{~km}$ de largura, com presença, na sua faixa mais interna ou ocidental, de terraço marinho pleistocênico com 5 a 6 m de altitude (Giannini et al., 2005), e, na parte externa, de terraço holocênico (Figura 1) mais baixo, formado por cordões litorâneos. A oeste do sistema planície costeira, o sistema lagunar encontra-se representado pelas lagunas Santo Antônio, Imaruí e Mirim, com margens internas recortadas por encostas do embasamento cristalino. Ele ocorre ainda em menor extensão a SW de Laguna Garopaba do Sul, onde separa o vale do Riachinho das lagoas Figueirinha e Laranjal.

O sistema planície de cordões diferencia-se do sistema barra-barreira pela maior altitude, pela idade máxima mais antiga e pelo caráter regressivo evidenciado pela maior largura e/ou pela sucessão de alinhamentos de cordões. A partir da distinção dos sistemas deposicionais que separam laguna de mar aberto a sul e a norte da Entrada da Barra, dois tipos de sistemas ou associações de fácies lagunares foram diferenciados (Giannini, 1993; Giannini et al., 2001), a baía-laguna e a vale-laguna, respectivamente. A baía-laguna (Garopaba do Sul, Camacho, Santa Marta) está posicionada a sul da desembocadura Entrada da Barra e inclui o delta do rio Tubarão como principal característica faciológica. Sua formação é atribuída ao isolamento parcial de corpo de água por crescimento de barreira arenosa transgressiva. Este corpo de água foi em seguida assoreado parcialmente pelo delta. Já a vale-laguna é mais bem desenvolvida a norte de Laguna (Santo Antônio, Imaruí, Mirim), mas ocorre também a sul (Sangão, Riachinho), e tem sua gênese ligada ao afogamento de vales de dissecação (vales incisos) em terraços marinhos regressivos preexistentes (pleistocênicos).

Segundo Giannini et al. (inédito), o sistema deposicional eólico superpõe-se à barreira arenosa em maior parte da área e ao sistema lagunar nas regiões de Campos Verdes e Garopaba do Sul. Este sistema abrange campos de dunas de pelo menos quatro diferentes gerações (Giannini 1993, Giannini \& Suguio 1994, Giannini et al. 2001), cujas idades variam do Pleistoceno superior ao atual (Sawakuchi 2003, Sawakuchi et al. 2003, Giannini et al. 2007). A geração eólica 1 seria aproximadamente contemporânea ao máximo NRM do último interglacial, e a geração 2, predominantemente anterior à máxima inundação holocênica, alcançada antes de 4 ka AP. A geração eólica 3, posterior a esta máxima inundação, apresenta idades LOE de até $6,3 \mathrm{ka}$, mas foi formada essencialmente nos últimos quatro milênios (Giannini et al. 2007). A geração 4 corresponde às dunas eólicas em atividade. Na área de domínio do sistema barreira holocênico, as gerações 1 e 2 restringem-se a dunas 
empoleiradas em pontões cristalinos, bem evidenciadas por exemplo no cabo de Santa Marta e nas pontas da Galheta e da Ilhota (Giannini 2003, Giannini et al. 2007).

Dentro desta área, são três os depósitos conchíferos de interesse neste estudo: os dos sítios arqueológicos Jabuticabeira II, situado na localidade de Jabuticabeira, e Encantada III, na localidade de Garopaba do Sul, ambos no município de Jaguaruna; e o do sambaqui Carniça III, na localidade de Campos Verdes, antiga vila da Carniça, município de Laguna.

O sambaqui Jabuticabeira II localiza-se nas proximidades do vale do Riachinho (Figura 1), cuja sedimentação holocênica foi estudada em detalhe por Amaral (2008). Possui $350 \mathrm{~m}$ de comprimento, $150 \mathrm{~m}$ de largura e $10 \mathrm{~m}$ de altura, com alongamento na direção NNW/SSE (Villagrán, 2008). Conforme se pode observar nos mapas de localização em relação aos sistemas deposicionais locais (Figura 1 e 2), este sítio assenta-se parte no flanco de uma paleoduna, parte em terreno paleolagunar (Giannini, 1993; De Blasis, 2005). Em trabalhos arqueológicos a partir da década de 1990, tem sido dividido em dois lócus ${ }^{1}$, correspondentes a antigas frentes de lavra de mineração de calcário conchífero.

${ }^{1}$ Lócus: Lugar ou localidade, do latim locus, plural loci. Termo comumente utilizado para designar e subdividir locais de intervenção arqueológica. 


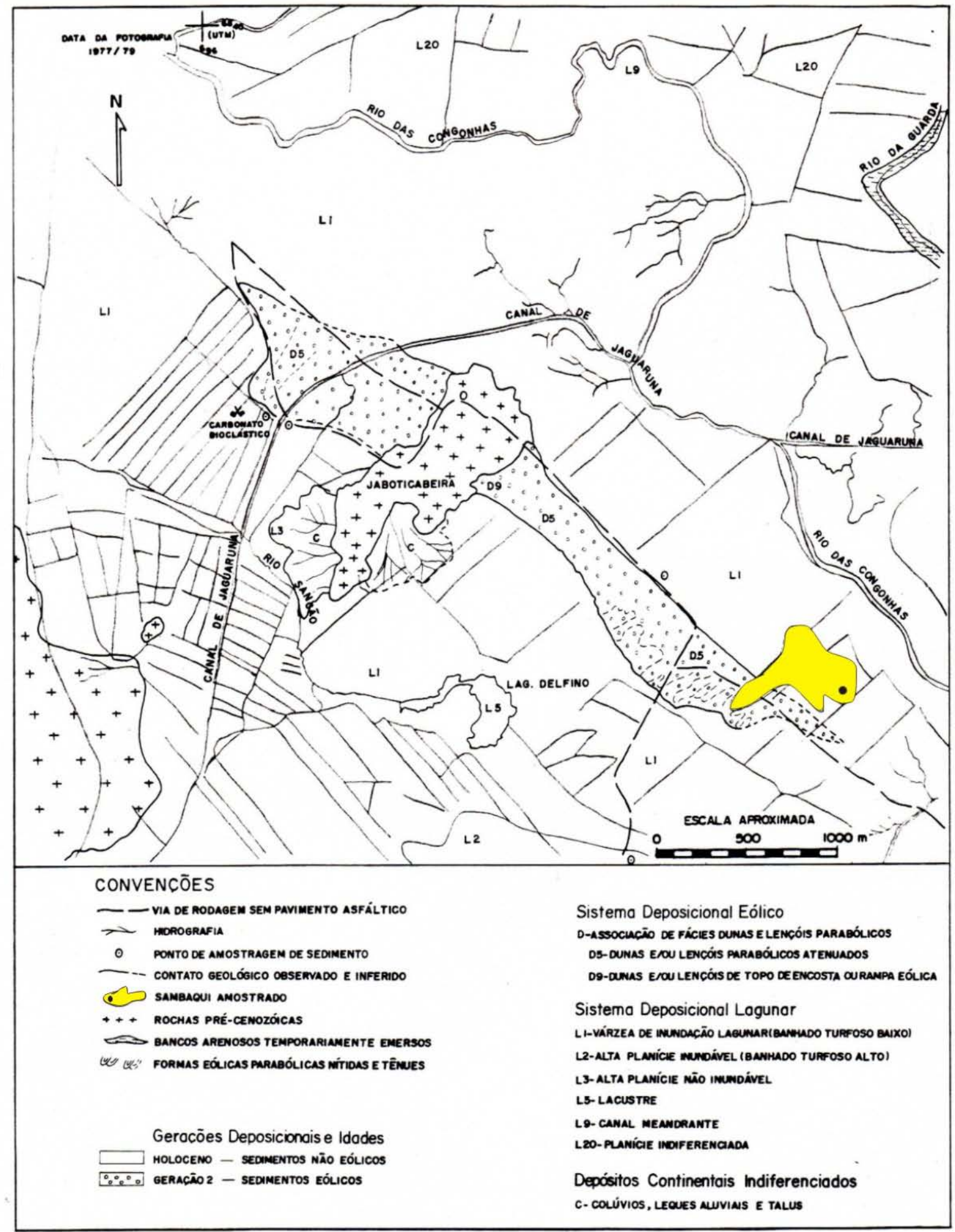

Figura 2 - Localização do sítio Jabuticabeira II (em amarelo) em relação aos sistemas deposicionais locais. Modificado de Giannini (1993). 


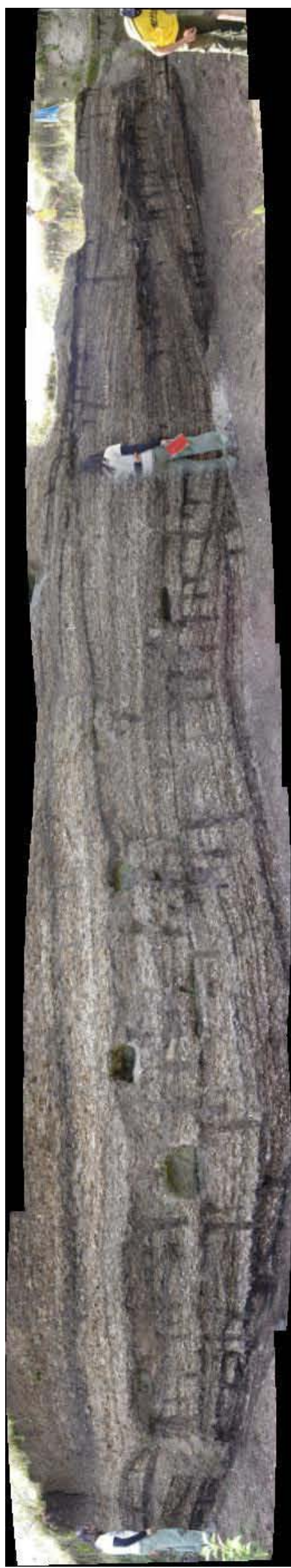

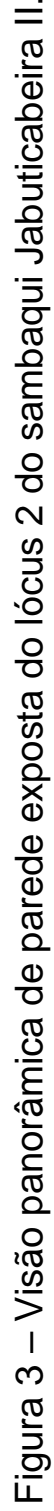


O sambaqui é composto por camadas predominantemente bioclásticas, com predomínio de Anomalocardia brasiliana, entremeadas por lâminas de sedimento preto carbonoso, com matéria orgânica ("camadas funerárias" sensu Klökler, 2001; DeBlasis, 2005; Bendazzoli, 2007), estas contendo freqüente presença de marcas de corte e preenchimento (marcas cônicas) de profundidade decimétrica (Figura 3). Este conjunto estratigraficamente rítmico é capeado por uma camada espessa (até $2 \mathrm{~m}$, conforme observação de campo) de sedimento preto carbonoso, com matéria orgânica, rico em ossos e líticos ("terra preta"). Esta camada de capeamento possui, conforme observações de campo, maior heterogeneidade quando comparada às lâminas de sedimento preto ("camadas funerárias") situadas estratigraficamente abaixo.

O sambaqui Encantada III é bem representativo de um segundo padrão de construção de sambaquis expressivo na região. Ele apresenta três particularidades ou diferenças marcantes em relação ao padrão construtivo mais comum ou conhecido em escala regional. A primeira são suas dimensões. Com menos de $2 \mathrm{~m}$ de altura e cerca de $15 \mathrm{~m}$ de largura por $34 \mathrm{~m}$ de comprimento ao longo da direção N225 (Figura 4A), este sambaqui destoa da monumentalidade tão freqüente em sítios arqueológicos de Laguna e Jaguaruna, como Garopaba do Sul I, Carniça I, Cabeçuda e Estreito, todos com centenas de metros de extensão e dezenas de metros de altura (Giannini et al., inédito).

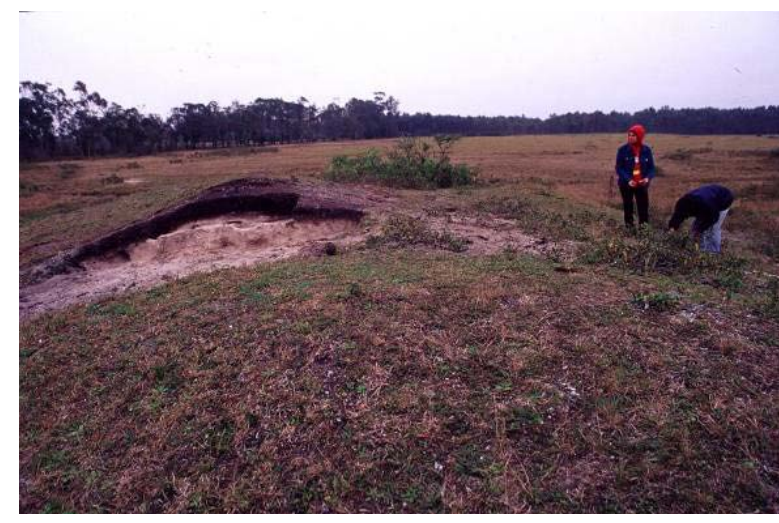

A

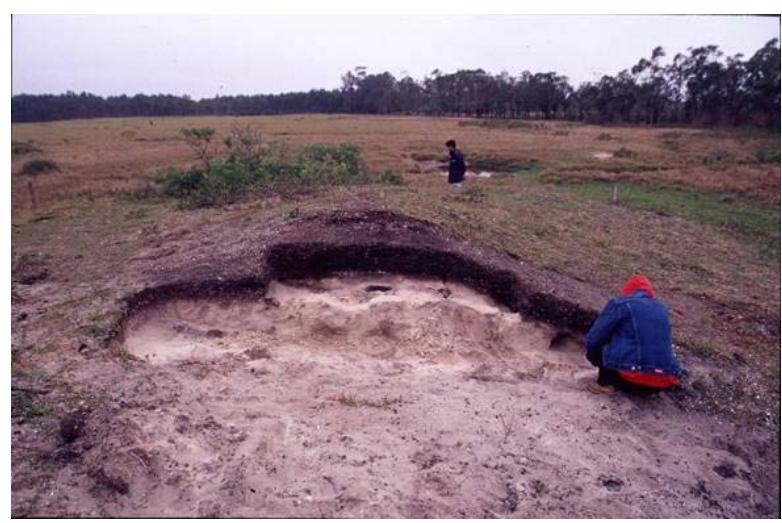

B SE. Fotos: P.C.F. Giannini, 2003

Sua segunda particularidade é a constituição, predominantemente arenosa. Trata-se, basicamente, de um montículo de areia limpa e incoesa, a menos de uma capa decimétrica de areia argilosa rica em matéria orgânica coloidal, com conchas (Figura 4B). Desse modo, lembra, não só na constituição, mas na própria forma, as dunas eólicas que marcam a paisagem local e regional. Suas dimensões reduzidas, bem como a simplicidade de forma, são convidativas para a descrição e interpretação estratigráfica relativamente detalhada de 
toda sua extensão (Giannini et al., inédito). Em relação a sua base, o Encandada III parece assentar-se sobre sedimentos de margem paleolagunar, porém, indistintos morfologicamente da barreira transgressiva e de lençol de areia eólica que podem estar presentes no local (Giannini et al., inédito).

O sambaqui Carniça III possui dimensão, composição e constituição morfológica semelhante ao sambaqui Encantada III e pode ser enquadrado, numa primeira análise, no mesmo padrão construtivo. Em observações de campo, nota-se capeamento de camada de "terra preta" misturada com conchas (predominantemente Anomalocardia brasiliana) sobreposta à areia quartzosa limpa e incoesa semelhante às areias de dunas eólicas presentes na região (Figura 5A e B). Neste sedimento quartzo-arenoso, é comum a ocorrência de rizoconcreções (concreções pseudomorfas de raízes) compostas por carbonato de cálcio, conforme verificado com $\mathrm{HCl} 10 \%$ in loco e confirmado em exame petrográfico (Mazini et al., 2007; Nardini et al., 2008).

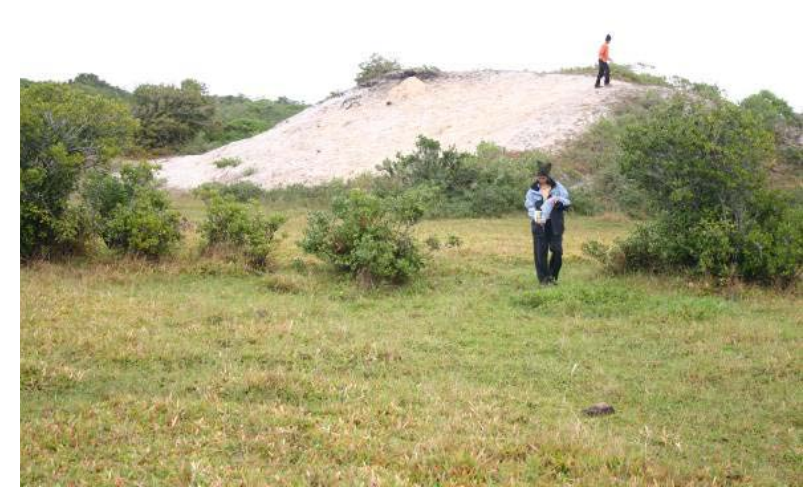

A

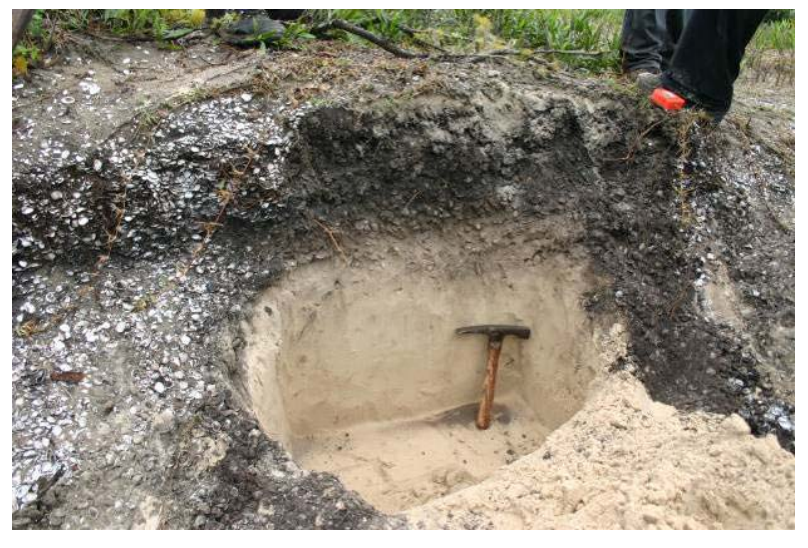

B

Figura 5 - Aspecto geral (A) e de detalhe (B) do sambaqui Carniça III.

Apesar de assemelhar-se, em morfologia e constituição, a uma duna eólica, o sambaqui Carniça III apresenta altura relativamente elevada, incompatível com as paleodunas da geração 3 assentadas sobre cordões litorâneos nesta região (Giannini, 1993; Tanaka, 2007).

\subsection{Sambaquis em relação à geologia sedimentar}

As datações de conchas em sambaquis já se mostraram eficientes em estudos conduzidos por Giannini (1993) para a estimativa da idade mínima de paleodunas eólicas que Ihe são substrato, bem como da idade máxima de dunas a eles superimpostas. Este exemplo ilustra a importância dos estudos de sambaquis no entendimento da evolução dos sistemas deposicionais fósseis ou ativos onde se inserem. 
Segundo contabilidade de Giannini (1993), o número de sambaquis na região entre Jaguaruna e Imbituba seria 73. Catalogação sistemática na região de Jaguaruna e Laguna, levada a cabo no âmbito de Projeto Temático FAPESP em andamento (04/11038-0), permite elevar este número para aproximadamente 90. Estas estimativas, ainda que não definitivas, tornam ainda mais evidente o potencial desta região como alvo para estudos integrados de sambaquis e contexto sedimentar.

De acordo com Giannini (1993) e Kneip (2004), a maioria (62\%) dos sambaquis da região entre Jaguaruna e Imbituba encontra-se na área onde predominam o sistema barrabarreira (com sistema eólico associado) e a baía-laguna. Esta concentração é interpretada como um padrão de assentamento preferencialmente voltado para grandes corpos de água litorâneos favoráveis à navegação (Gaspar, 2000) e também à visibilidade por longas distâncias (Kneip 2004). A comunidade sambaquieira teria se mantido deliberadamente restrita às porções externas e menos acidentadas da faixa litorânea, enquanto o planalto teria sido ocupado, mais ou menos contemporaneamente, por culturas líticas da Tradição Umbu (Gaspar 2000; Giannini et al., 2005). Sob esse aspecto, o sistema planície de cordões e a vale-laguna, mais acidentados e próximos das encostas do embasamento cristalino précenozóico (Figura 1), teriam tido sua ocupação desfavorecida em relação à barreira e à baíalaguna, de geomorfogia plana (conforme descrição do item 1.3).

\subsection{Matérias primas geológicas na construção de sambaquis}

Estudos arqueológicos realizados no litoral centro-sul catarinense, a partir da década de 1990, têm demonstrado que os sambaquis são monumentos ou marcos paisagísticos intencionais, erguidos por sociedades sedentárias organizadas, onde as conchas, mais que possíveis restos de alimentação, representariam um tipo específico e preferencial de material construtivo (DeBlasis et al., 1998; Gaspar, 2000; Giannini et al., 2005).

Giannini et al. (2005) verificaram aparente semelhança textural e composicional entre parte das camadas pretas encontradas em sambaquis da região, ricas em material pelítico e matéria orgânica (bastante conhecidas no meio arqueológico pelo termo informal "terras pretas"), e depósitos paleolagunares presentes em subsuperfície nas proximidades destes sambaquis. Com base nessa semelhança e na premissa do sambaqui como construção intencional, a questão-chave levantada por aqueles autores e que se coloca como tema neste subitem, pode ser assim enunciada: "a comunidade sambaquieira apenas coletava moluscos vivos ou recentemente mortos, em meio a lama e bioclastos do fundo lagunar da época? Ou poderia também ter escavado depósitos sedimentares preexistentes, em busca de tipos específicos de materiais construtivos?". 
As camadas pretas são encontradas em vários sambaquis da região, com destaque para os de Carniça III, Encantada III e Jabuticabeira II, escolhidos para focalização neste estudo. Elas possuem duas formas principais de ocorrência: como lâminas sub-centimétricas intercaladas com camadas ricas em conchas, conforme observado no sambaqui Jabuticabeira II (Jaguaruna) e em parte dos sambaquis da planície de Campos Verdes (Laguna), denominados Carniça por Hurt (1974); ou compondo uma espécie de capa, com espessura decimétrica a métrica, como bem caracterizado nos sambaquis de Jabuticabeira II e Encantada III. Na visão da arqueologia, a capa de "terra preta", especialmente no sítio Jabuticabeira II, representa o final da ocupação pela sociedade sambaquieira. E a interface entre a porção superior da camada rica em conchas e esta capa contém o registro de importante mudança cultural, ainda não se sabe se gradual ou brusca.

Ainda no sambaqui Jabuticabeira II, a camada preta que o recobre é acompanhada subsuperficialmente por camada concrecionar de carbonato e fosfato de cálcio (Mazini \& Giannini, 2007; Nardini et al., 2008), produto de processo pós-deposicional semelhante aos fenômenos eodiagenéticos que promovem a litificação precoce de calcários e fosforitos (Gianinni et al., 2005). Este mesmo sambaqui repousa parcialmente sobre paleodunas eólicas cujas areias avermelhadas são similares à lente de espessura centimétrica encontrada em meio à estratigrafia do sambaqui (Gianinni et al., 2005).

Neste cenário de evidentes inter-relações entre a construção de sambaquis e uma série de fatores geológicos como processos e sistemas deposicionais (paleolagunas e paleodunas), materiais construtivos (bioclastos, sedimentos orgânicos, areias eólicas) e fenômenos pós-deposicionais (formação de concreções), é que se aponta a necessidade de um refinamento dos estudos da constituição dos sambaquis (composição e uso de matériasprimas do ambiente geológico), a fim de se compreender os processos naturais que serviram de pano de fundo para este universo cultural tão bem registrado em Santa Catarina: os sambaquis e seus construtores.

\subsection{Objeto e estrutura desta dissertação}

Esta dissertação possui como objetos de estudo principais os sambaquis Jabuticabeira II, Encantada III e Carniça III, e suas respectivas áreas de entorno. Estes sambaquis são representativos de dois padrões construtivos expressivos em escala regional, distintos quanto ao porte e à complexidade estratigráfica, sendo o sambaqui Jabuticabeira II maior e aparentemente mais complexo que os outros dois. 
Dentre os pontos levantados na sessão de brainstorm (mencionada no item 1.1) que deu origem a esta pesquisa, surgem duas questões principais a respeito destes três sambaquis: (1) a análise de fácies pode ser aplicada no entendimento do empilhamento estratigráfico?; e (2) qual a origem dos materiais constituintes destes sítios? Estes questionamentos resultaram nas metas desta Dissertação, apresentadas no item 2. Os objetivos, expostos no mesmo item, são as questões que apareceram concomitantemente às metas mas que indicam, na prática, o que se propôs fazer em campo e laboratório para tentar atendê-las.

No item 3 - "Métodos de abordagem: discussão crítica", tem-se o debate acerca de dois dos métodos que foram utilizados neste trabalho, a análise de fácies e a análise microscópica. Este item inclui revisão bibliográfica e discussão sobre o uso destes métodos em arqueologia, divididos em cinco subitens. Os subitens 3.1 a 3.3 abrangem a evolução dos conhecimentos estratigráficos no contexto da arqueologia, passando pela definição do conceito de fácies em geologia (subitem 3.2), com destaque para as concepções de Allen (1983), Anderton (1985) e Miall $(1985,1996)$. Esta discussão metodológica do conceito de fácies encerra-se com o retorno do tema ao contexto da arqueologia (subitens 3.2.6 e 3.2.7), onde se tenta resgatar na bibliografia a utilização de análise de fácies em sambaquis.

Com o item 3.3 - "Visão extra-sítio", uma escala estratigráfica mais abrangente é trazida para a discussão, onde se utilizam trabalhos prévios regionais para correlacionar os sambaquis aos sistemas deposicionais do centro-sul de Santa Catarina.

O item 3.4 é dedicado ao tema microscopia, em uma tentativa de mostrar as diferenças e similaridades entre seus usos na micromorfologia de solos e na petrografia sedimentar. Abrange exame e proposta sobre a viabilidade de aproximação entre as duas técnicas, tendo em vista sua aplicação em arqueologia.

O item 3 é encerrado com as definições de camada, estrato e lâmina escolhidas para este trabalho, com a finalidade de evitar os problemas de duplicidade ou ambigüidade de uso desses termos, freqüentemente obervados na interface da geologia com a arqueologia.

O item 4 insere-se, como o anterior, no domínio dos métodos, agora porém de modo mais descritivo. Apresenta, embasado na discussão metodológica do item 3, os procedimentos de campo (4.1) e de laboratório (4.2) utilizados neste estudo.

No item 5, os resultados obtidos são descritos e pré-discutidos, utilizando recursos gráficos. Este item está subdividido por ensaio realizado, de modo a melhor explorar cada tipo de dado analítico obtido. Os subitens 5.1, 5.2 e 5.3 estão subdivididos por localidade, identificados pelas toponímias: Jabuticabeira, que compreende o sítio arqueológico 
Jabuticabeira II e paleolaguna adjacente (borda oeste da paleolaguna Garopaba do Sul); Garopaba do Sul, que inclui o sambaqui Encantadas III e arredores; e Campos Verdes, abrangendo o sítio Carniça III e sedimentos geogênicos locais.

Reservou-se para o item 6 - "Discussão dos resultados", o desenvolvimento do debate iniciado de forma embrionária no item anterior. Este item está subdividido em dois temas: análise de fácies" (item 6.1) e proveniência dos sedimentos dos sambaquis estudados (item 6.2), coincidentes com as metas desta Dissertação.

No item 7, listam-se, em estrutura de tópicos, as principais deduções do estudo, de forma a responder sucintamente aos objetivos propostos.

Por fim, o Anexo reúne os dados brutos ou semi-tratados, na forma de tabelas e gráficos, tendo em vista a consulta e avaliação dos resultados pela comunidade científica. 


\section{METAS E OBJETIVOS}

Os objetivos específicos da pesquisa de Mestrado atendem a dois aspectos principais colocados como metas (conforme definição deste termo no item 1.1) ou objetivos maiores: (1) a aplicação de análise de fácies e de arquitetura deposicional em sambaquis; e (2) a investigação do uso de sedimentos paleolagunares como seu material construtivo.

Relacionados à meta 1, desdobram-se os dois primeiros objetivos desta Dissertação:

a. Avaliar a eficiência da utilização de camadas de "terra preta", e respectivos horizontes preferenciais de sepultamento, como marcadores estratigráficos ou de superfícies delimitantes, com ênfase, por critério de qualidade de exposição, no sambaqui Jabuticabeira II.

b. Analisar as características texturais e composicionais de cada fácies e os padrões de associação e recorrência de fácies nas seções escolhidas.

Com relação ao segundo sub-tema ou meta, outros três objetivos foram estabelecidos:

a. Comparar camadas de "terra preta" e "camadas funerárias" nos sambaquis e sedimentos paleolagunares ricos em matéria orgânica quanto a textura, mineralogia e composição isotópica, com o intuito de estabelecer sua proveniência.

b. Verificar se houve preservação de estruturas (escala de afloramento) e texturas (escala microscópica) deposicionais originais não antrópicas, para testar a hipótese de que a "terra preta" e as "camadas funerárias" sejam um depósito geogênico remanejado integralmente pelo homem.

c. Fazer comparações texturais e mineralógicas das fácies arenáceas quartzosas, (abundantes nos sambaquis Carniça III e Encantada III), com depósitos naturais dos sistemas lagunar, eólico e barreira. 


\section{MÉTODOS DE ABORDAGEM: DISCUSSÃO CRÍTICA}

\subsection{Introdução: evolução do uso da estratigrafia em arqueologia}

A estratigrafia e a arqueologia estiveram juntas a partir do século 18, quando se passou a buscar um aprofundamento do conhecimento acerca da antigüidade humana, com o conseqüente rompimento com as teorias criacionistas (Villagrán, 2008). Com o desenvolvimento da antropologia comportamental, houve, todavia, um distanciamento da arqueologia em relação a estratigrafia geológica, especialmente a partir do século 19.

Os objetos de estudo da estratigrafia são a descrição, a origem e as relações temporais e espaciais entre camadas de rocha ou de sedimentos (Stein, 1992; p 72). Seu arcabouço teórico evoluiu dos conceitos primordiais de Nicolas Steno (1638-1683), como a lei de superposição, os princípios da horizontalidade original e da continuidade lateral e a relação temporal de superfícies discordantes (uma superfície, estrato ou corpo rochoso que corta discordantemente um estrato é a ele posterior), para princípios mais complexos, como a análise de fácies e a estratigrafia de seqüências. Esta evolução teve a influência da agregação de novas tecnologias aliadas às análises de campo e laboratório.

Enquanto a estratigrafia (geológica) avançava, impulsionada por incrementos tecnológicos e econômicos (a prospecção petrolífera no início do século 20, por exemplo), a arqueologia focava-se sobretudo na busca de um significado cultural para os sítios, onde o contexto geológico era visto como mero invólucro do artefato. Esta visão impediu aos arqueólogos, durante algum tempo, dissociar o significado cultural do artefato do significado deposicional do estrato, pois, como o foco era no processo cultural, a visão do processo "natural" (ou geológico) resultava a ele subordinado; desse modo, não se permitia "enxergar" a interação entre os dois tipos de processos de forma mútua, nem a possibilidade de sua atuação concomitante, onde ora predomina um, ora outro.

Somente a partir da segunda metade do século 20, alguns estudos arqueológicos passaram a incluir a estratigrafia (Stein, 1992: p.73), porém foram trabalhos como os de Gasche e Tunca $(1983)$ e Stein $(1987,1990)$ que promoveram o reencontro da estratigrafia com a arqueologia. Foi nesta época que floresceram as sistematizações de nomenclaturas estratigráficas aplicadas à arqueologia, muito próximas da nomenclatura já existente em litoestratigrafia e bioestratigrafia, em contraponto com sistemas estratigráficos estritamente arqueológicos como o formulado por Harris $(1979,1989)$. 
O sistema atual da nomenclatura estratigráfica, tal qual proposto pela American Code of Stratigraphic Nomenclature (NACSN) de 1983, divide as sucessões de rochas ou depósitos com base em litologia (unidades litoestratigráficas), conteúdo fossilífero (unidades bioestratigráficas) e períodos de tempo nos quais houve deposição (unidades cronoestratigráficas, geocronológicas e geocronométricas). Este sistema de nomenclatura agregou posteriormente termos aplicados à arqueologia, tais como: unidades etnoestratigráficas (relativas ao conteúdo artefatual), cujo método de análise se baseia em identificação de zonas (intervalo, assembléia e abundância) análogas às biozonas (unidade fundamental da bioestratigrafia); e unidades etno-cronoestratigráficas, correspondentes a estratos formados em um mesmo intervalo de tempo, interpretado com base na descrição dos artefatos (Stein, 1992).

A criação deste sistema de nomenclatura estratigráfica rompe com termos mais antigos, criados a partir do início do século 20, mas que de algum modo perduram até hoje, tais como: componente (ou fase na Europa), fase (ou cultura na Europa), estágio, período, horizonte e tradição (Willey e Phillips, 1958; Fagan, 1988 apud Stein, 1992). Esses termos não possuem uniformidade de utilização e variam em seu significado de acordo com o autor; além disso, possuem definições abstrusas, quando atreladas a características culturais, e misturam conceitos cronológicos com descritivos.

Para Gasche e Tunca (1983), a focalização dos estudos em sítios arqueológicos não se pode dar somente no aspecto artefatual, tampouco apenas no litoestratigráfico, pois os limites de ocorrência dos artefatos não estão estritamente vinculados à litologia e vice-versa.

Esses autores propuseram a separação entre unidades cronoestratigráficas (ligadas a duração e relações temporais) e etnoestratigráficas (ligadas a classes de artefatos), onde o papel da litologia é ser referência para escavação, fonte de informação a respeito da dinâmica de sedimentação e erosão e critério para traçar relações topográficas entre os depósitos e organizar a coleta de artefatos (Gasche e Tunca, 1983). Porém, a delimitação de unidades cronoestratigráficas baseadas na natureza do conteúdo, onde se separa o antrópico do natural (oriundos de fenômenos geológicos), gera dubiedade, já que a definição da origem (natural ou antrópica) do objeto estudado pode não ser facilmente determinada, além de ser interpretativa. Ademais, conforme observado por Stein (1992: p 84), a estratigrafia pode ser aplicada qualquer que seja a origem do material.

Stein (1992) propõe a utilização da estratigrafia como ferramenta no auxílio da organização e caracterização dos sítios arqueológicos de forma multifacetada, isto é, de modo a compreender litoestratigrafia, etnoestratigrafia, cronoestratigrafia, entre outros, em 
múltiplas seções; a justificativa da autora é que somente o confronto de dados, seções e perfis permite um entendimento mais completo dos processos formativos de um sítio.

O exposto até aqui não pressupõe o abandono das técnicas tradicionais de escavação, onde se trabalha o sítio horizontalmente, com vista à representatividade em área; pressupõe, isto sim, a complementação das observações da escavação com a inclusão de seções geológicas e colunares, visando cobrir as variações verticais do sítio, de forma a compreender rápida e concisamente os processos formativos.

Um desdobramento evolutivo muito natural do uso da estratigrafia em arqueologia, nos dias atuais, seria o uso do conceito de fácies (conforme Anderton, 1985 e Walker, 2006, a definir no item 3.2). Este termo é utilizado em geologia há quase duzentos anos, e, a exemplo do próprio arcabouço teórico da estratigrafia, sofreu diversas modificações de significado e aplicação. Chega aos dias de hoje como um dos conceitos de maior utilidade na otimização da análise estratigráfica e na análise de processos geológicos, mas certamente não teve ainda todo o seu potencial explorado em arqueologia.

\subsection{Usos do conceito de fácies e termos associados}

\subsubsection{Fácies}

"Facies are the smaller-scale building blocks of the sedimentary record" (Walker, 1983)

O uso moderno do conceito de fácies foi introduzido em geologia pelo suíço Amanz Gressly (1814-1865), que observou a variação lateral no conteúdo fossilífero, entre outras características, de determinado estrato, e a atribuiu a variação das condições deposicionais originais (Walker, 2006).

A utilização do conceito de fácies é muito ampla, e sua definição variou muito ao longo do tempo e de autor para autor. O importante é ter em mente que os limites da descrição, agrupamento e interpretação de fácies são dados pelo autor, como uma visão pessoal e conforme as conveniências de seu estudo; não existe um modelo de fácies onde seja possível a delimitação de todos os processos envolvidos, e que possa ser utilizado de forma única. Isto não invalida o uso de modelos, mas apenas a idéia de modelo único ou modelo norma. Não existe um modelo, mas infinitos.

Para o estudo a que se propõe este trabalho, julga-se conveniente a utilização do conceito de fácies proposto por Walker $(1976,2006)$ e por Anderton (1985). Para estes autores, o termo fácies pode ser utilizado de forma descritiva ou interpretativa. A fácies 
descritiva refere-se a um determinado volume (de rocha ou depósito inconsolidado) que pode ser caracterizado por uma série de feições, tais como granulação, forma externa e estrutura, que permite distingui-lo de outras unidades de volume do depósito. Já a fácies interpretativa é o rótulo colocado sobre a unidade descritiva, que a referencia aos processos e "ambientes" deposicionais responsáveis por sua deposição (Anderton, 1985). É importante observar que o conceito de fácies descritiva, por ser abrangente, abriga qualquer tipo de material, desde que este tenha sido depositado, e não possui conotação genética nem temporal. Isso vai contra o uso interpretativo do conceito de fácies, ainda que este caráter não esteja explícito (p. ex. "fácies fluvial" de Selley, 1982, p. 265 apud Anderton, 1985).

A vantagem da utilização do conceito de fácies é a adaptabilidade à finalidade e caráter do estudo geológico, ou seja, as fácies é que se moldam ao estudo em desenvolvimento e não o estudo que se molda a um modelo de fácies preestabelecido.

\subsubsection{Análise de fácies}

A análise de fácies consiste na descrição e classificação de qualquer corpo sedimentar seguido de interpretação dos processos e ambientes de deposição, comumente sob a forma de um modelo, o modelo de fácies (Anderton, 1985). Corresponde, portanto, à aplicação do conceito de fácies com o intuito de interpretar os processos deposicionais. Um exemplo de análise de fácies pode ser visto na Tabela 1, compilado e traduzido de Rossetti et al. (2004).

Existem várias formas de descrição e representação de sucessões de fácies sedimentares (exemplo na Figura 6). Elas podem ser unidimensionais (perfis de testemunhos de sondagem), bidimensionais (seções colunares, geológicas ou estratigráficas) ou tridimensionais (diagramas em cerca, blocos-diagrama), onde o tipo de descrição e grau de detalhamento fica a critério do autor, balizado pelo objetivo do estudo. 
Tabela 1- Exemplo de análise de fácies. Modificado de Rossetti et al. (2004).

\begin{tabular}{|c|c|c|}
\hline $\begin{array}{l}\text { Tipo de } \\
\text { rocha }\end{array}$ & Descrição de fácies & $\begin{array}{l}\text { Interpretação das condições } \\
\text { deposicionais }\end{array}$ \\
\hline Evaporito & $\begin{array}{l}\text { Gl - gipso laminado } \\
\text { Gm } \quad-\quad \text { gipso } \\
\text { maciço/macrogranular } \\
\text { Gy - gipsarenito }\end{array}$ & $\begin{array}{l}\text { Deposição rasa, subaquosa e efêmera } \\
\text { em planícies de inundação (pans) } \\
\text { marginais lamosas e salinas. }\end{array}$ \\
\hline Calcário & $\begin{array}{l}\text { Mm - mudstone maciço } \\
\text { Mpl - mudstone-packstone } \\
\text { laminado } \\
\mathrm{T} \text { - tufa } \\
\mathrm{B} \text { - brecha }\end{array}$ & $\begin{array}{l}\text { Condições deposicionais subaquosas, } \\
\text { rasos e de baixa energia distantes de } \\
\text { fontes terrígenas importantes, com } \\
\text { exposição subaérea periódica. } \\
\text { Considerando o sistema deposicional } \\
\text { proposto, estes depósitos formaram-se, } \\
\text { provavelmente, às margens de planícies } \\
\text { de inundação (pans) lamosas e salinas. }\end{array}$ \\
\hline Argilito & $\begin{array}{l}\mathrm{Al} \text { - argilito laminado } \\
\mathrm{Am} \text { - argilito maciço } \\
\mathrm{Sb} \text { - folhelho negro }\end{array}$ & $\begin{array}{l}\text { Deposição por decantação de sedimento } \\
\text { em suspensão em de planícies de } \\
\text { inundação (pans) subaquosas de baixa } \\
\text { energia, lamosas e salinas }\end{array}$ \\
\hline
\end{tabular}




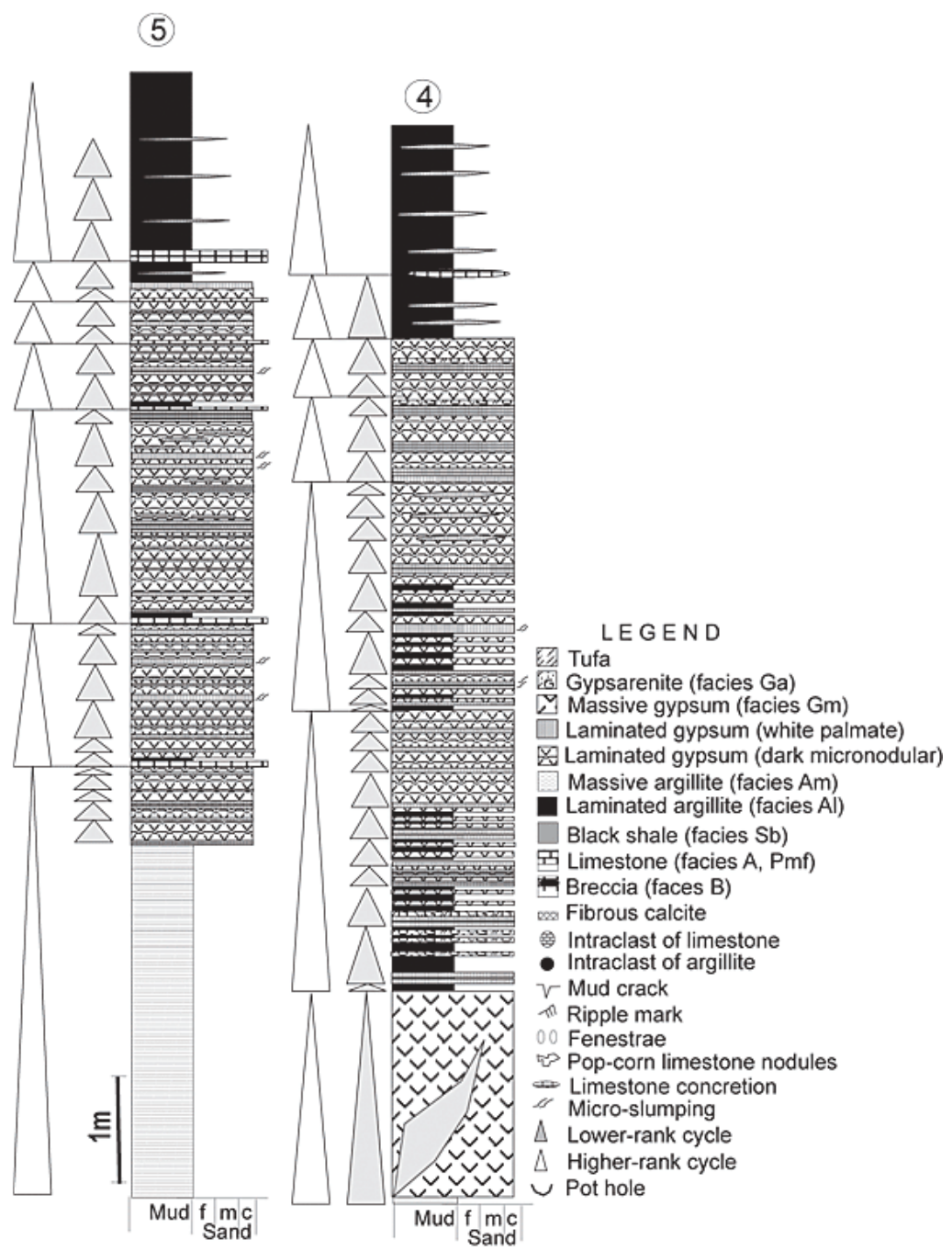

Figura 6 - Exemplo de representação estilizada, em seção colunar e perfis (ciclos granocrescentes e granodecrescentes na forma de triângulos), de composição de fácies originalmente expostas em diversos afloramentos. Compilado de Rossetti et al. (2004).

A definição de análise de fácies descrita algures foi concebida para utilização em problemas específicos da sedimentologia. Porém, observa-se que sua aplicação cabe em qualquer tipo de depósito, desde que a cada fácies possa ser associado um processo deposicional específico.

\subsubsection{Associações de fácies}

Após a definição, descrição e representação de um grupo de fácies em escala e detalhamento descritivo desejados, e a fim de se conceber um modelo de fácies (resultado final), parte-se para a interpretação das fácies. A interpretação pode ser auxiliada pelo uso do conceito de associação de fácies. 
A associação de fácies, de acordo com a definição de Collinson (1969 apud Walker, 2006), consiste de um grupo de fácies geneticamente relacionadas e que possuam algum significado em termos de "ambiente" deposicional (aqui usado num sentido próximo ao de sistema deposicional). Mesmo autor propõe o agrupamento de fácies de acordo com características interpretativas acerca do "ambiente deposicional". Este tipo de associação pode ser feita após uma análise mais aprofundada sobre as características genéticas das fácies estudadas, porém não antes de se descreverem as características faciológicas (Figura 7). Giannini (2007, p.152) define associação de fácies como "conjunto de fácies vizinhas que formem arranjos preferenciais e que tenham posições relativas preferenciais dentro do sistema" deposicional. Uma associação de fácies, segundo o autor, deve ter expressão tempo-espacial determinada e ser, portanto, separável das demais por limites físicos. No registro estratigráfico, estes limites têm sido designados "superfícies de separação" ou de descontinuidade (Allen, 1983) e o litossoma assim delimitado "unidade ou elemento arquitetônico" sensu Allen (1983) e Miall (1985) (Giannini, 2007, p.13).

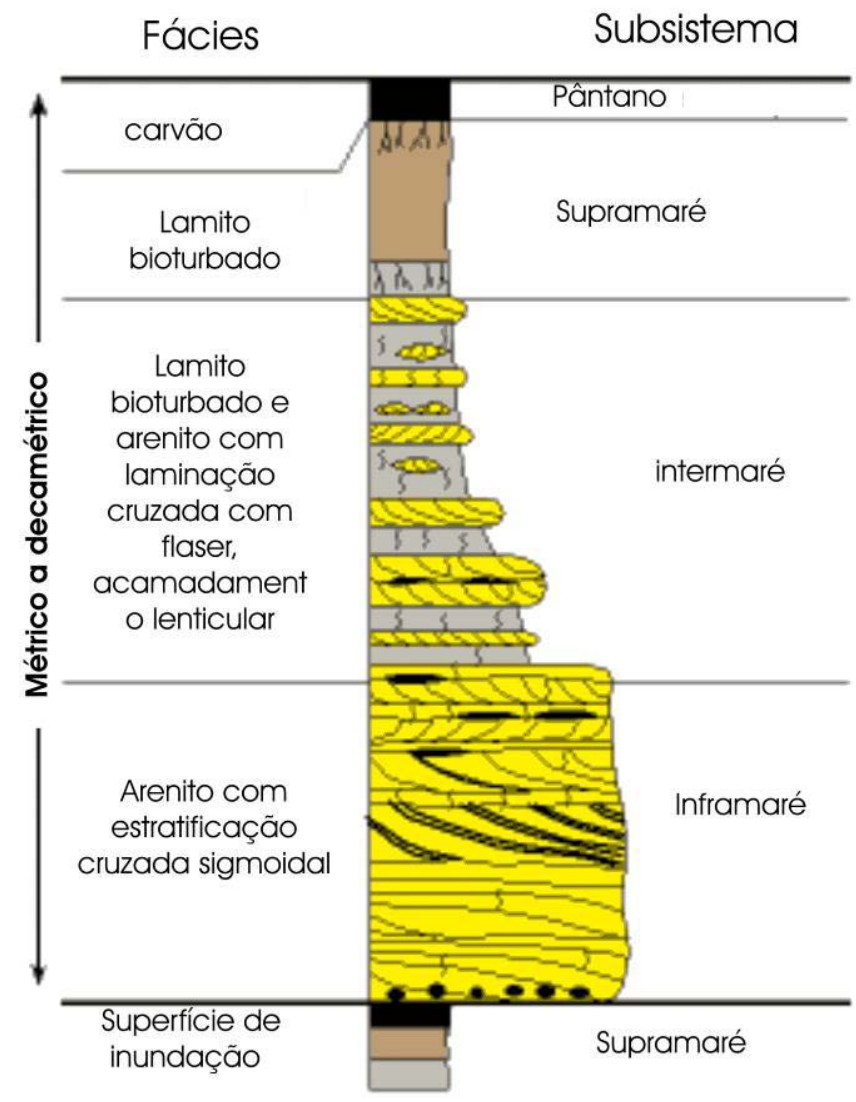

Figura 7 - Exemplo de uso do conceito de associações de fácies, em depósitos de planície de maré, como recurso para a interpretação do local de deposição. Modificado de Holland (2008). 


\subsubsection{Elementos arquitetônicos e superfícies delimitantes}

Elementos arquitetônicos (architectural elements) são definidos por agrupamentos de associações de fácies hierarquizados através de superfícies delimitantes.

A análise de elementos arquitetônicos proposta por Miall (1985) implica a identificação de descontinuidades físicas hierarquizadas (superfícies delimitantes) que subdividem uma sucessão (aluvial, no caso de Miall) geneticamente relacionada e hierarquicamente estruturada (Ferreira Junior e Castro, 2001). A utilização do método proposto por Miall (1985) pressupõe a utilização de seções aflorantes de grande continuidade lateral, de tal forma que seja permitida uma análise bidimensional destinada a observar a geometria dos corpos sedimentares.

As superfícies delimitantes são geradas por mudanças no regime de deposição, seja por uma interrupção (hiato) atrelada ou não a mudança do processo deposicional, seja por processos erosivos e até pedogenéticos. Estas superfícies são comumente hierarquizadas de acordo com sua importância em termos de eventos deposicionais e sua escala tempoespacial de atuação (Figura 8). 


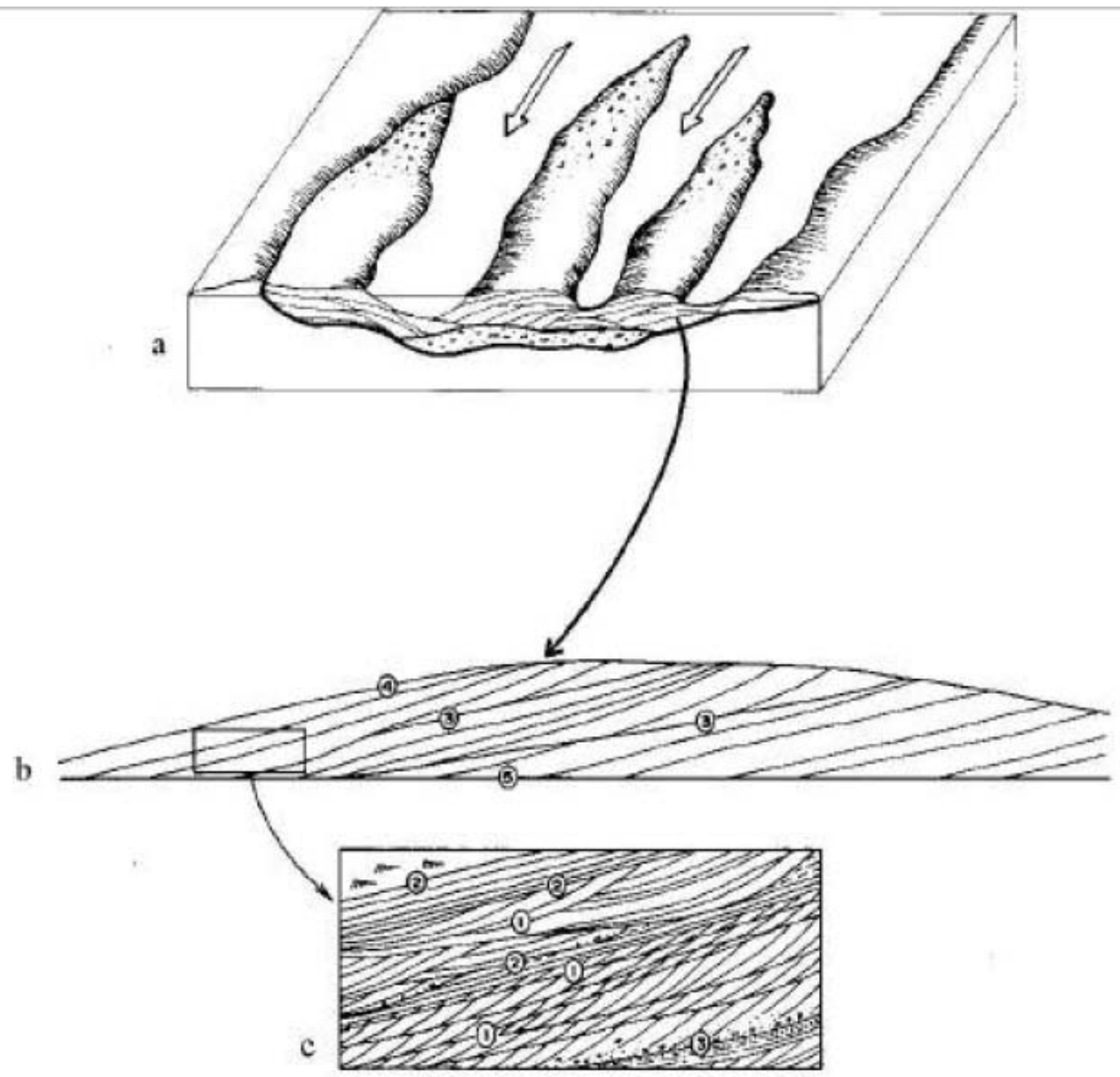

Figura 8 - Esquema de hierarquização das superfícies delimitantes de elementos arquitetônicos. Os números no interior dos círculos indicam a hierarquia da superfície. Compilado de Ferreira Junior e Castro (2001).

\subsubsection{Modelos de fácies}

"Facies can be organized into "facies sequences" (today we would use the term facies successions), and various sequences and successions in particular depositional environments can be synthesized into models for that environment" (Walker, 2006, p 2).

A meta da análise de fácies é a produção de um modelo de fácies que, segundo Anderton (1985), consiste na descrição da origem, características, comportamento e evolução do todo ou uma parte de um sistema sedimentar, real ou imaginário, em termos de um conjunto definido e realista de variáveis e limites; é a tentativa de dividir um determinado fenômeno complexo em uma série de compartimentos, visando à simplificação, tal qual é o 
objetivo dos modelos científicos em geral; é a descrição do complexo nos termos de seu análogo mais simples (Anderton, 1985); é descrever como, e não porque, o sistema funciona.

O conceito de Walker (1979, 1984) e Potter (2005 apud Walker, 2006) é, aparentemente, mais ambicioso que o exposto por Anderton (1985). Potter (2005 apud Walker, 2006) indica que o modelo de fácies deve servir para melhorar a previsibilidade e o entendimento de como diferentes rochas ou sedimentos, que formam fácies recorrentes, se agrupam para formar um modelo, que, segundo Walker (2006), possa ser utilizado como padrão.

A confecção de um modelo de fácies, segundo as definições revisadas, implica:

a. Delimitação de fácies, preferencialmente de caráter descritivo;

b. Verificação de recorrências e sucessões entre as fácies delimitadas;

c. Agrupamento das fácies recorrentes e ordenamento das sucessões a fim de se formar uma ou mais associações de fácies (ou elemento arquitetônico), por analogia com modelos modernos observados diretamente, frutos de experimentação ou teorias (Ferreira Junior e Castro, 2001);

d. Formação de um modelo de fácies (local ou regional), a partir da interpretação das associações de fácies.

De posse do modelo de fácies, surge o questionamento: Para que se destina? Walker (1979) enumera quatro funções principais para o uso do modelo:

a. Norma, para comparações;

b. Guia, para futuras observações;

c. Previsor, para a utilização em novas situações;

d. Base para interpretação.

Anderton (1985) critica duas (norma e base) das quatro funções do modelo enumeradas por Walker (1979), por se tratar de finalidades demasiadamente estáticas em relação à evolução do conhecimento científico, e que não contemplam o número crescente de variações faciológicas reconhecidas à medida que mais sistemas deposicionais similares são descritos. Acrescenta-se que a criação de um modelo não deve ser necessariamente a normatização de um determinado processo, pois, admitindo que o controle total das variáveis de um processo jamais será alcançado, o modelo servirá apenas de guia ou ponto de partida para o entendimento de dado processo, seja ele deposicional ou formativo. 
A leitura dessas definições faz surgir questionamentos acerca da eficiência da predictibilidade dos modelos. Será possível cercar todas as variáveis (em ambientes deposicionais naturais ou em processos formativos de sítios arqueológicos) e propor um modelo que responda de maneira satisfatória a todos os questionamentos?

Para responder a esta pergunta, recorre-se a uma frase de Anderton (1985), p 33:

“...If, like me, you have a more nihilistic view of life, the universe and everything, then you have to admit an infinite number of environments, facies and models".

Portanto, sugere-se que a análise de fácies contenha o maior grau de observações descritivas possível, respeitando os objetivos do estudo, pois é dependente destas observações a coerência das interpretações que embasarão os modelos de fácies.

\subsubsection{Aplicações de análise de fácies na estratigrafia de sambaquis}

A definição de fácies utilizada em geologia sedimentar é diretamente aplicável a camadas arqueológicas. Em arqueologia, no entanto, os processos deposicionais possuem caráter não somente natural (geogênico e/ou pedogênico), como antropogênico, conforme ressaltado por Courty (2001). Desse modo, os limites de fácies arqueológicas, segundo essa autora, resultam igualmente mistos.

Além de utilizar o termo fácies em depósitos arqueológicos, Courty (2001) aplica ao mesmo contexto o conceito de associação de fácies. O uso deste termo é feito de duas formas, as associações de fácies horizontais e as "seqüências" (sucessões) verticais de fácies. O primeiro uso refere-se à variação lateral dentro de um estrato - uma mesma superfície de ocupação formada por feições remetentes a usos distintos (p. ex.: local de passagem, dormitório, local de estocagem ou descarte de comida, entre outros). Já a "seqüência" vertical de fácies refere-se às mudanças do padrão de ocupação de um mesmo espaço e a alterações nele introduzidas por processos geomórficos. Preocupada em não repetir o equívoco cometido no passado com o uso do conceito de fácies em sedimentologia, a autora acrescenta que a arqueologia deve evitar a mistura de termos interpretativos com descritivos na sua caracterização.

Stein et al. (1992) utilizou o termo fácies para designar "a menor unidade litoestratigráfica" no sambaqui de British Camp, na costa noroeste dos Estados Unidos. O termo foi aplicado para enfatizar mudanças litológicas tanto verticais como horizontais. A fácies, no contexto do sambaqui estudado, representava um evento deposicional individual, conseqüência da deposição, em um só lugar, de materiais trazidos pelos povos préhistóricos, resultado de uma combinação de atividades. Este evento deposicional poderia ter 
durado horas, dias, anos ou séculos. Uma boa analogia foi utilizada pelos autores para explicar a relação tempo de deposição versus fácies: uma pessoa despejando um balde de conchas por ano no mesmo lugar por 25 anos produziria uma fácies; 25 pessoas despejando um balde de conchas cada, em uma hora, produziriam uma fácies. Esta analogia ressalta o fato de que o tempo envolvido na deposição da fácies não deve ser critério para sua definição (Stein et al., 1992).

Para a descrição das fácies do sambaqui, Stein et al. (1992) utilizaram um conjunto de parâmetros, identificados no campo durante a escavação, como a presença de matriz, de rocha e de conchas. Este conjunto de parâmetros foi determinado por uma observação prévia do sítio, o que propiciou a identificação de valores e características de cada parâmetro (quantidade e textura de conchas e rochas e coloração e granulação de matriz). O conjunto de parâmetros, valores e características utilizados por Stein et al. (1992) é ilustrado pelo dendrograma da Figura 9.

O material recolhido de cada fácies identificada por Stein et. al. (1992) foi peneirado e quantificado em campo, e cada fácies (baseada na litologia), em cada unidade de escavação, foi representada em uma matriz de Harris (vide Harris, 1989).

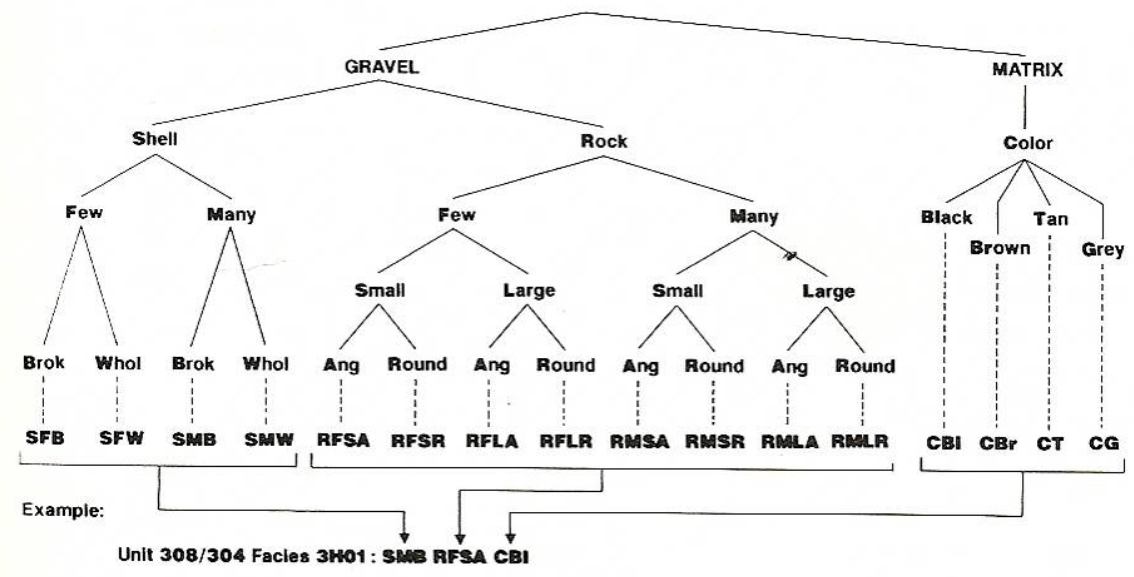

Figura 9 - Exemplo de classificação de fácies por Stein et al. (1992), aplicada à litologia da unidade 308/304 do sambaqui British Camp, em San Juan Island, Washington, EUA. Gravel = cascalho. Matrix $=$ areia, silte e argila. Shell $=$ conchas. Rock $=$ rocha. Few $=<25 \%$. Many $=>25 \%$. Brok $=$ quebrada. Whol $=$ inteira. Ang $=$ anguloso. Round $=$ arredondada .

Os atributos físicos, organizados em fácies e agrupados com o auxílio da matriz de Harris, conformaram unidades litoestratigráficas delimitadas de acordo com os mesmos parâmetros que permitiram a separação de fácies. O desenho em seções realizado por Stein et al. (1992) não envolveu delimitação de superfícies de separação entre fácies. Ou seja, representaram-se apenas os objetos maiores que $1 \mathrm{~cm}$ e, posteriormente, as linhas para cada unidade litoestratigráfica foram traçadas. 
Stein et al. (1992) confrontaram várias técnicas estratigráficas para a obtenção da estratigrafia geral do sambaqui de British Camp (fácies + matriz de Harris = litoestratigrafia e etnoestratigrafia). Apesar de terem alcançado o objetivo com propriedade, os autores não utilizaram todo o potencial da análise de fácies em seções, a saber: a exploração das formas das superfícies que confinam as fácies; sua relação com os estratos adjacentes e a identificação de superfícies delimitantes de associações de fácies genética e/ou descritivamente relacionadas. Esta utilização plena da análise de fácies poderia ter tornado o processo de construção da estratigrafia do sambaqui ainda mais ágil.

Atualmente, assiste-se ao avanço do método de análise de fácies na construção estratigráfica em sítios arqueológicos ou de sistemas deposicionais ligados a esses sítios. Entre outros, podem ser citados os trabalhos de Giannini (1993), Courty (2000), Giannini et al. (2005), Villagrán (2008) e Villagrán et. al. (2009).

Nos trabalhos de Villagrán (2008) e Villagrán et. al. (2009), o uso da análise de fácies em escala de sítio arqueológico é mais contundente. No primeiro trabalho, utilizou-se o conceito de fácies em campo na descrição de seções expostas do sambaqui Jabuticabeira II, onde se descreveram os atributos físicos (composição e geometria interna e externa), para organizar a estratigrafia em fácies e subfácies. Para cada fácies, Villagrán (2008, p. 34), atribuiu a nomenclatura "arqueofácies", a qual definiu no seguinte contexto:

"No intuito de estabelecer uma linguagem padronizada para o registro arqueossedimentar, todo e qualquer conceito emprestado da geologia deve ser sistematicamente adaptado. Assim como os sedimentos arqueológicos são definidos diferentemente dos sedimentos naturais, a análise de fácies aplicada a seu estudo deve envolver também conceitos específicos, pelo processo responsável pela sua configuração e pelos objetivos próprios desta análise, vinculados ao estudo de sistemas culturais passados. Por isso, no contexto da análise estratigráfica de fácies dos sítios arqueológicos, propõe-se o uso do conceito de arqueofácies, termo que pode ser usado indistintamente com "fácies arqueológicas" usado por Brochier (2002) 2."

${ }^{2}$ Brochier, J. E., 2002. Les sediments anthropiques: methodes d'etude et perspectives. In: Jean Claude Miskovsky. (Ed), Geologie de la Préhistoire. Geopré, Presses Universitaires de Perpignan, Paris, pp. 453-477. 
Com a intenção de utilizar o conceito de fácies em arqueologia, Villagrán (2008) e propuseram, na fração teórica de seu trabalho, a reconfiguração do conceito para adequá-lo aos propósitos arqueológicos. Esta adaptação é porém, antes uma conveniência operacional para finalidades de interpretação de que uma necessidade conceitual a priori. Isto porque o conceito de fácies é, por definição, um sistema aberto, que abrange o entendimento da relação processo-produto em contextos deposicionais de qualquer natureza. As fácies podem ser utilizadas, tal como na concepção adotada por Anderton (1985) e Walker (2006), para qualquer produto sedimentar, seja ele depositado "naturalmente" ou antropicamente, pois em sua definição dita "geológica", não se exige um tipo padrão de processo. Ou seja, o uso do conceito de fácies como unidade básica de descrição (o que inviabiliza a utilização de subfácies, uma vez que a fácies já é a unidade descritiva elementar) permite acessar o processo físico-mecânico de deposição, cujo contexto ou "meio de transporte" já faz parte da interpretação. Um exemplo clássico são as estruturas chamadas de "estratificações cruzadas": seu processo físico-mecânico formador é razoalvelmente conhecido (deposição em superfície inclinada), mas pode ser atrelado a uma enormidade de situações geológicas (migrações de formas de leito de diferentes geometrias e escalas, formadas por ondas ou correntes, em meio aquoso ou aéreo) e a uma infinidade de sistemas deposicionais (fluviais, eólicos, costeiros, de leques aluviais etc).

Em arqueologia, os processos culturais são vistos por alguns autores como análogos aos processos deposicionais. Schiffer (1976) define processo cultural como as ações físicas básicas exercidas por humanos em sua esfera de atuação, mais especificamente, em sua superfície de ocupação. Para este autor, os processos culturais podem ser resumidos em acumulação, transformação e redistribuição. Estes processos refletem uma suposta "intencionalidade deposicional", difícil de ser inferida e observada pelos meios disponíveis em arqueologia (vestígios materiais). Em contrapartida aos métodos mais etéreos de identificação de processos deposicionais, a utilização do conceito de fácies em sedimentos clásticos preconiza a relação do registro com processos físico-mecânicos de deposição. Ao utilizar-se de lógica dedutiva calcada nas evidências materiais disponíveis, a análise de fácies dispensa, e mesmo refuta, qualquer interpretação a respeito da intencionalidade do processo.

Em suma, por sua "moldabilidade" a diferentes tipos de depósitos, a análise de fácies pode ser conduzida em sedimentos antrópicos sem mudanças substanciais, uma vez que permite a interpretação do processo físico-mecânico de deposição de qualquer agente transportador, ficando a cargo do pesquisador a interpretação dos processos deposicionais/formativos "naturais" (geogênicos) ou culturais, de acordo com modelos experimentais ou teóricos. 


\subsubsection{Exercício teórico - análise de fácies em arqueologia}

A estratigrafia em geociências evoluiu muito rapidamente nas últimas décadas, porém a estratigrafia aplicada à arqueologia não acompanhou esta evolução. Uma das principais conseqüências disso é que o uso de técnicas estratigráficas específicas em estudos de sítios arqueológicos freqüentemente negligencia a relação entre sistema deposicional geológico e sistema deposicional antrópico.

O desenvolvimento e aplicação da análise de fácies na sua conceituação mais moderna (Walker, 2006), adaptada ao objeto de estudo arqueológico, permitem maior eficiência na dedução de processos formativos, tanto naturais como antrópicos, em sítios arqueológicos. Apesar disso, ainda se encontram no meio arqueológico utilizações do termo obsoletas ou conceitualmente distintas do original (por exemplo, como sinônimo de unidade litoestratigráfica), bem como alguma resistência na adoção do conceito de fácies tal qual se utiliza hoje em dia em sedimentologia.

A despeito dessas dificuldades, alguns trabalhos mais recentes já se encontram influenciados pela perspectiva da fácies como elo processo-produto, como observado nos estudos do sítio Jabuticabeira II, mencionados no subitem 3.2.6 (ver também 6.1), onde se observam associações estratigráficas realizadas aos moldes da análise de fácies (Bendazzolli, 2007) ou utilização explícita e contundente do conceito de fácies (Villagrán, 2008).

Estes trabalhos demonstram possível tendência de utilização cada vez maior da análise de fácies em sítios arqueológicos. Esta tendência pode ser considerada bem vinda, a menos de dois problemas principais de adaptação do conceito: o uso de termos técnicos associados, como camada, lâmina e lente, sem a devida precisão, e a criação de terminologias derivadas (por exemplo, arqueofácies), a rigor desnecessárias em vista da versatilidade do conceito de fácies, por definição.

Para nortear esta retomada do conceito de fácies em arqueologia, alguns passos ou diretrizes podem ser colocadas para o procedimento de identificação de fácies em sítios arqueológicos. Dentre outros, destacam-se: determinação da escala da unidade básica (fácies) de descrição do sítio arqueológico, a partir da observação e subdivisão preliminar do sítio; atribuição das características composicionais das fácies (componentes orgânicos, inorgânicos e artefatuais), e estimativa preliminar, em campo, de suas respectivas proporções em massa ou volume; atribuição das características morfológicas das fácies (bi, ou mesmo tridimensionais, quando possível), bem como de seus limites. 
Já na montagem de hipóteses sobre o processo formativo do sítio, quando de posse da maior quantidade de dados descritivos possível, os principais passos seriam: mapeamento e hierarquização de superfícies de descontinuidade; estabelecimento de associações espaciais entre as fácies, delimitadas por aquelas superfícies, visando reconhecer elementos arquitetônicos (unidades geométricas maiores de construção) em escala de sítio; e montagem de um modelo de fácies voltado à interpretação do processo formativo do sítio, a ser exaustivamente testado, na etapa seguinte, a partir de dedução lógica de características e reexame do sítio.

\subsection{Visão extra-sítio: a correlação sambaquis versus sistemas deposicionais}

A estratigrafia pode atuar como ferramenta nos estudos de interação sítio - ambiente (ou cenário, sensu Giannini et al., 2005) "natural" (geogênico) de deposição. Uma correta análise de fácies em sítios arqueológicos deve permitir a extensão da análise para fora do sítio, na tentativa de estabelecer as relações de processos formativos arqueológicos com processos deposicionais em ambientes geológicos. Mas a análise de fácies é apenas uma das ferramentas geológicas que podem ser utilizadas na reconstrução da relação sítio cenário natural. A análise de proveniência comparece aí como outra importante ferramenta.

Um exemplo de correlação entre cenário deposicional e sítio, voltada para a questão da proveniência, encontra-se no contexto do estudo de Villagrán (2008), onde, para o sambaqui Jabuticabeira II, a autora faz uma verificação da hipótese levantada por Giannini et al. (2005), segundo a qual a semelhança textural e composicional dos sedimentos escuros (camada de "terra preta") de sambaquis da região com os sedimentos orgânicos de paleolagunas adjacentes seria indicativa de contribuição destes sedimentos como fonte de material construtivo. Villagrán (2008) analisou a granulometria da fração areia recolhida no sítio e em poços de controle localizados sobre terreno paleolagunar em Garopaba do Sul e realizou comparações gráfico-estatísticas, via diagramas de dispersão, com os dados obtidos por Giannini (1993), Sawakuchi (2003) e Martinho (2004) referentes às e paleodunas eólicas da região próxima ao sítio. Desta forma, a autora concluiu que o sedimento arenoso do sítio possui de fato maior afinidade com os sedimentos paleolagunares de que com os sedimentos eólicos.

A própria análise da localização dos sítios, balizada pela conformação do sistema deposicional (do paleo ao atual), permite inferências acerca das motivações construtivas, no caso, da população responsável pelo erguimento dos sambaquis de Santa Catarina. 
Encaixa-se neste tipo de procedimento o apresentado por Hurt (1974), ao estipular as condições hipotéticas para a construção e para o abandono de quatro sambaquis (Ponta das Almas, Caieira, Carniça e Carniça 1A) situados em Laguna (SC). De acordo com esse autor, a dependência dos recursos marinhos por parte das populações sambaquieiras (o autor talvez tenha apontado esta dependência pelo simples fato de os sambaquis constituírem-se em majestosas construções conchíferas) teria acarretado a construção de sambaquis às margens das fontes de subsistência (mar, laguna e rios). Nesse contexto, condições adversas de oscilação de marés, ondas de tempestade e drenagem teriam sido "a causa" da construção dos sambaquis mais ao interior na planície litorânea (Hurt, 1974). Já a hipótese de Hurt (1974) para o abandono dos sítios é a de isolamento das áreas dos sambaquis devido a fatores como: trangressão ou regressão marinha, assoreamento do sistema estuarino-lagunar (principal fonte de moluscos), formação de "barra arenosa associada à baía" [sistema barra-barreira], assoreamento dos corpos de água resultante do crescimento de vegetação halófita ou exaustão dos recursos alimentícios (ostras de mangue, por exemplo) por superexploração e invasão de outros povos (Hurt, 1974). O autor aventa ainda que as razões prováveis para a existência de tipos característicos de sambaquis residiriam no modo como estas populações se adaptaram ao meio (habitat).

A análise geológica e geográfica avançou desde o trabalho de Hurt (1974) e tornou possível a Kneip (2004) a utilização de Sistema de Informação Geográfica (SIG, ou GIS em inglês) para o entendimento da dinâmica da relação entre os sambaquis (ou o "povo da lagoa", nas palavras do autor) e a paleogeografia da região. O estudo de Kneip (2004), utilizando modelos digitais de terreno e simulações de emersão gradual baseadas na curva de NRM de Angulo et al. (1999) permitiu concluir que, com o rebaixamento de NRM de aproximadamente $2 \mathrm{~m}$, no decorrer dos últimos 5 a 6 mil anos, as lagunas tiveram sua área diminuída, o que ocasionou sucessivos abandonos de sítios, cada vez mais distanciados dos corpos de água, bem como novas construções próximas às margens de lagunas, de forma a perseguir os recursos necessários à sobrevivência da população sambaquieira.

Muitas foram as correlações entre sambaquis e NRM na literatura geológicoquaternarista, na tentativa de utilizar os sambaquis como marcos na interpretação de níveis pretéritos e, com uso de dados de vários sambaquis, de construir curvas de variação do NRM. Em Santa Catarina, destacam-se os trabalhos de Suguio et al. (1985) e Martin et al. (1988). Porém, como exposto por Giannini et al. (2005), os sambaquis são, na melhor das hipóteses e admitida a premissa do substrato seco, controlados pela posição da linha de costa. A dinâmica de linha de costa, por sua vez, não depende somente do NRM, mas sim de todos os fatores locais e regionais capazes de determinar a relação entre aporte sedimentar (As) e espaço de acomodação de sedimentos (Ea). No litoral sul catarinense, a dinâmica de 
balanço sedimentar é controlada por fatores tipicamente sub-regionais ou mesmo locais, sendo o primeiro deles o aporte fluvial e eólico, o segundo as correntes de deriva litorânea e o terceiro a dinâmica de desembocaduras lagunares (Giannini et al., 2005). Segundo estes autores, a região onde se situam os sambaquis-foco deste estudo é constituída por zonas de equilíbrio erosivo-deposicional instável, o que realça a importância do fator As no comportamento da linha de costa, em detrimento do fator Ea, controlado pelo NRM.

Como é possível perceber a partir do exposto, os sambaquis constituíram-se em construções complexas (estratigráfica e culturalmente) e dinâmicas em seu posicionamento geográfico.

\subsection{Exame microscópico: o casamento da micromorfologia com a petrografia sedimentar}

A pedografia, ou "micromorfologia de solos" (sensu Stoops, 2003) é a descrição sistemática de solos, baseada em observação de campo, amostra de mão, seção delgada e aplicação de outras técnicas, voltada à avaliação de tamanho, forma, arranjo e identificação de seus constituintes (Brewer, 1976). Colocando nos termos de um especialista, Stoops (2003), que revisou os trabalhos de Brewer (1976) e Bullock (1985), a meta da pedografia é a procura por processos responsáveis pela formação ou transformação do solo em geral, ou por feições específicas, naturais (revestimentos, nódulos, por exemplo) ou artificiais (crostas de irrigação, plow pans). Conseqüentemente, é uma ferramenta importante na investigação da gênese, classificação ou gestão de solos e regolitos. Já a petrografia sedimentar é definida por Milner (1962) como uma descrição sistemática de sedimentos, através da análise conjunta de mineralogia e litologia. Esta descrição, quando integrada à interpretação dos processos deposicionais e pós-deposicionais, passa a receber o nome de petrologia sedimentar.

Segundo Brewer (1976), a pedologia (ou a "ciência dos solos") tem como objetivo o estudo dos processos geradores de solos, por meio dos instrumentos fornecidos pela pedografia. A partir desse raciocínio, o autor conclui que a pedografia está para a petrografia, assim como a pedologia está para a petrologia.

Uma vez que a pedologia é ramo de uma ciência mais abrangente - a geologia (ou a "ciência que trata do planeta como um todo", segundo Brewer, 1976), o estudo pedológico não se pode confinar na análise do solo, mas sim estender-se aos materiais relacionados (rochas). A partir deste ponto de vista, conclui-se que a pedografia e a petrografia devem atuar como análises complementares na elucidação dos processos formativos dos solos. 
Em arqueologia, o entendimento da interrelação entre as atividades humanas e os agentes naturais foi aprimorado com a aplicação de técnicas microscópicas no estudo dos sedimentos arqueológicos (Courty et al., 1989 apud Courty, 2001). Porém, a adaptação dos conceitos e métodos da pedografia em arqueologia (desenvolvida para atender a uma demanda de questões acerca do processo de formação de solos de sítios arqueológicos) não é satisfatória, devido ao grau de complexidade dos sedimentos e solos arqueológicos. Ademais, segundo Courty (2001, p.207), os conceitos e os métodos microscópicos utilizados em arqueologia são mais próximos à rotina analítica da petrografia sedimentar. A autora acrescenta que a classificação de fácies, amplamente utilizada na geologia sedimentar, difere conceitualmente do estudo do "arranjo" (fabric) em pedologia, por seu caráter essencialmente descritivo, sem conotação genética implícita. Em contrapartida, existem pontos de convergência entre a análise de fácies deposicionais e o estudo de feições micromorfológicas: primeiro estas feições não necessariamente têm caráter genético conhecido; segundo, elas podem ser utilizadas como refinamento das fácies determinadas em campo.

A micromorfologia é requisitada em arqueologia principalmente quando se esgotam as possibilidades de resolução de problemas específicos (ver exemplo na Figura 10) com uso das ferramentas arqueológicas tradicionais (descrição e coleta de artefatos em escavações e seções, análises químicas e granulométricas, entre outras). O papel do micromorfólogo passa a ser então o de refinar o entendimento da estratigrafia do sítio arqueológico, por meio da análise de textura e composição em escala microscópica e até relacionar funcionalidades de certas estruturas, como as de combustão (rituais, de cozimento, de aquecimento etc). 

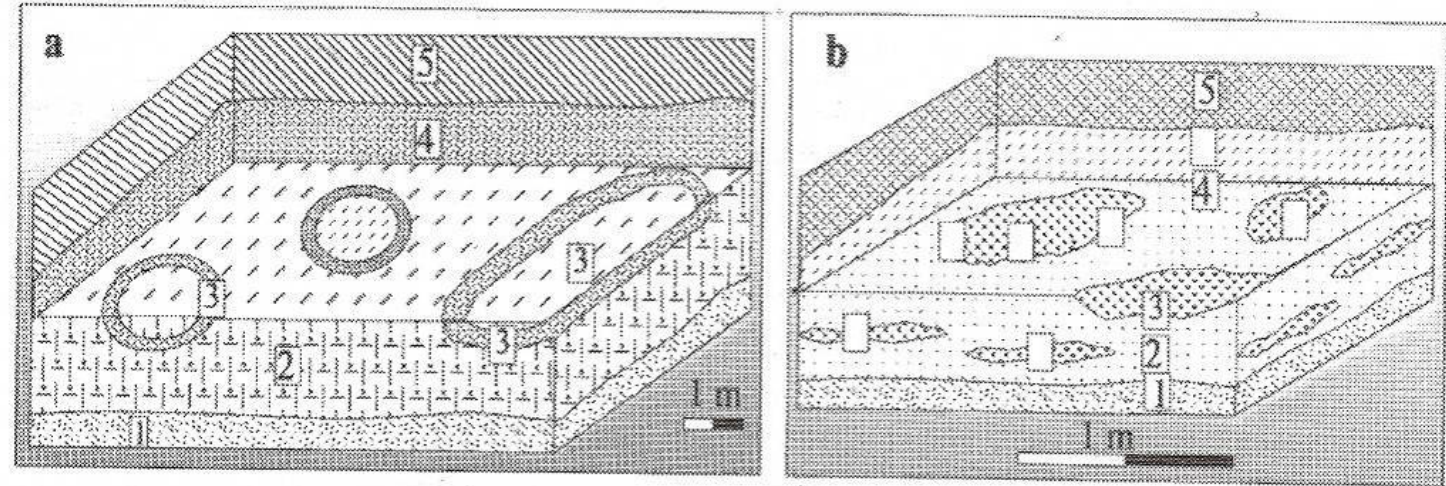

Figura 10 - Exemplo hipotético de situação arqueológica que requer uso da micromorfologia, demandado por questões específicas. (a) Valas circulares e alongadas com preenchimento de solo incomum e artefatos, sugerindo estruturas funerárias, em sítio a céu aberto. Questionamentos: qual a origem do material de preenchimento das valas e qual o ritmo de deposição? (os retângulos indicam locais de amostragem). (b) Seqüência de abrigo composto por quatro estratos arqueológicos de fácies distintas. A camada 2 apresenta lentes difusas com cinzas (3), interpretadas como estruturas de combustão pouco ordenadas. Questionamentos: qual o modo e as condições deposicionais específicos para cada fase de ocupação e quais as funções das estruturas de combustão? Modificado de Courty (2001).

\subsubsection{Feições pedogenéticas e sedimentares}

Os processos geradores do solo podem atuar sobre depósitos sedimentares e confundir-se com processos similares que ocorrem durante a sedimentação. Desse modo, muitas das feições pedogênicas assemelham-se a feições deposicionais. Apesar disso, algumas feições podem ser consideradas bastantes características de solos.

Dentre estas feições características, distinguíveis em micromorfologia, destacam-se: a presença de raízes ou de seus vestígios - feições indicativas de crescimento vegetal, só possível sob condição de pouca ou nenhuma sedimentação; a acumulação de matéria orgânica e de minerais secundários em quantidades variáveis; certas feições estruturais, tais como descontinuidades, vazios e peds (na definição de Retallack, 2001, agregados de solo entre fissuras, raízes, túbulos, e outros tipos de descontinuidades; Figura 11); os cutans ou revestimentos (Figura 12), superfícies modificadas de peds, clastos ou cristais (Retallack, 2001); os nódulos ou glaebules, (Figura 13); os cristais neoformados, que ocorrem geralmente preenchendo vazios (Figura 17); os pedotúbulos, estruturas tubulares em geral, atribuídas com freqüência a escavações de animais e traços de raízes (Figura 14); os pellets (ou pelotilhas), geralmente de origem fecal (Figura 14); e as microestruturas, principalmente as do plasma ou micromassa, nomes atribuídos à porção fina do solo (Retallack, 2001). Muitas das feições mencionadas também são reconhecidas em petrografia sedimentar, o que evidencia a superposição de ambas as técnicas microscópicas e dos processos e produtos que são objetos de seu estudo. 


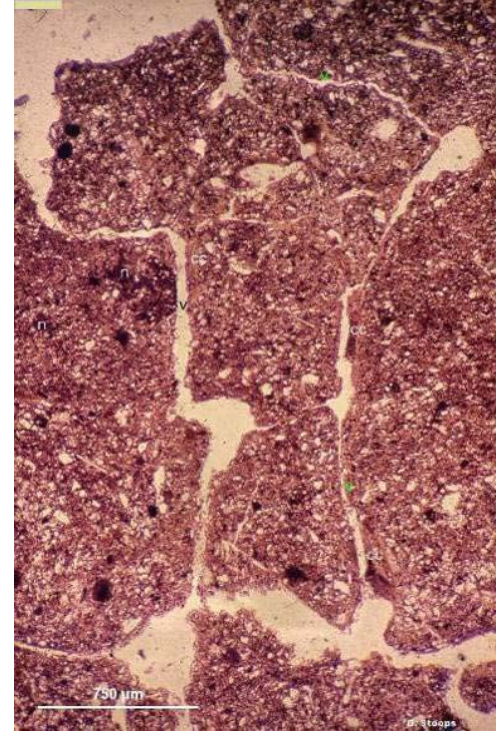

Figura 11 - Exemplo de peds em microestrutura de blocos subangulares "muito separados". Notar planos de acomodação (v) entre os peds, revestimentos de argila interpedal (cc) e nódulos difusos de hidróxido de $\mathrm{Mn}$ intrapedais (n). Horizonte argílico. Polarizadores paralelos. Fotomicrografia de Stoops (2003).

Figura 13 - Exemplo de nódulo órtico de calcita (Ca) em meio a massa basal cinza amarelado (gm). Polarizadores paralelos. Fotomicrografia de Stoops

(2003).

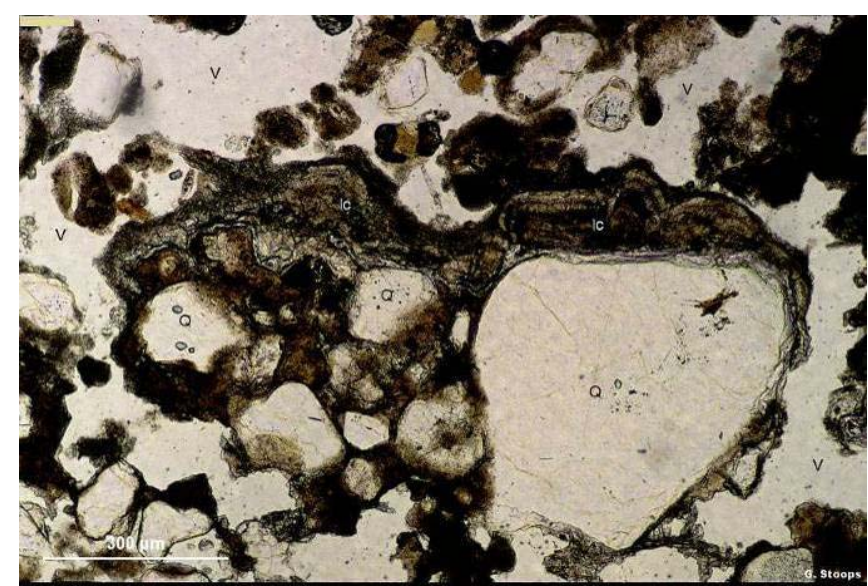

Figura 12 - Exemplo de revestimento do tipo capa ligante (linking cap) ou geopetal (Ic) formada por calcita. Observam-se vazios (v) e grãos de quartzo (Q). Polarizadores paralelos. Fotomicrografia de Stoops (2003).

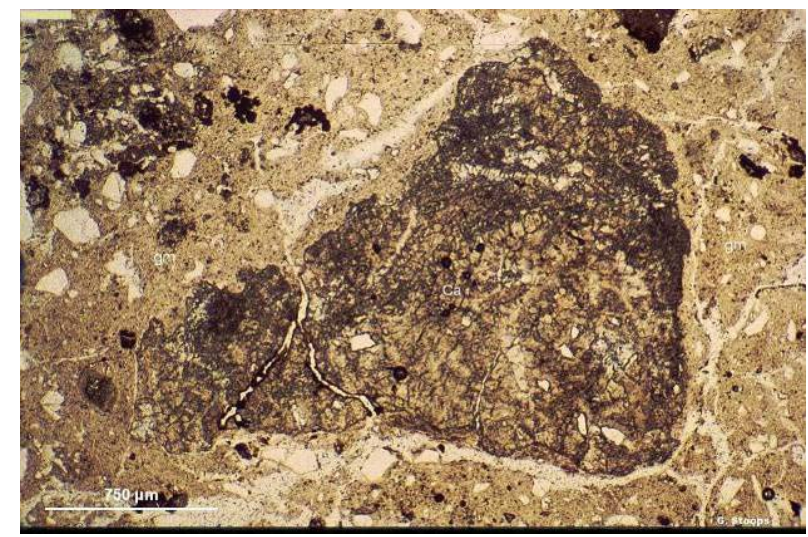




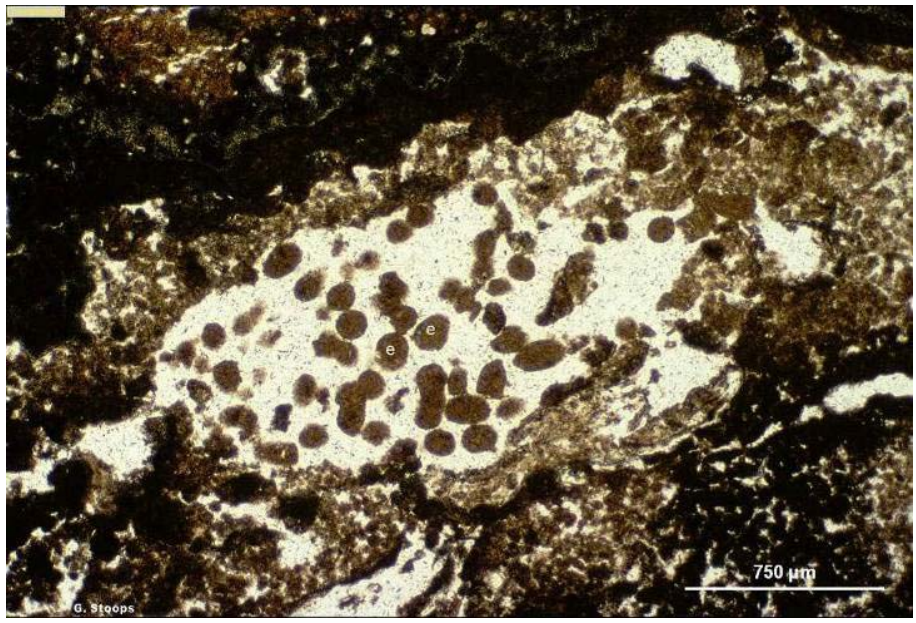

Figura 14 - Exemplo de preenchimento de canal por excrementos elipsóides (e) compostos por calcita micrítica e argila. Polarizadores paralelos. Fotomicrografia de Stoops (2003).

Entre as feições similares encontradas em depósitos sedimentares, destacam-se: as pelotilhas (ou pellets) (Figura 15), que embora sejam clásticas por definição, assemelham-se em textura e gênese provável aos excrementos da pedografia (Figura 14); as cutículas (sensu Gesicki, 2007) (Figura 16), formadas em condições diagenéticas, e semelhantes aos revestimentos de argila; e os preenchimentos de cavidades ou cristais flutuantes (pseudoespatos) na matriz (grosso modo, equivalente a massa basal em pedografia) (Figura 17).

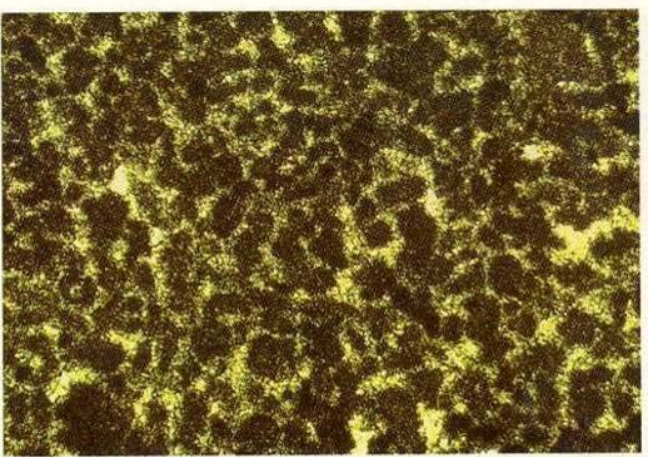

$0.5 \mathrm{~mm} \mathrm{PL}$
Figura 15 - Exemplo de pelotilhas ou pellets em contexto sedimentar (pelotilhas clásticas). Calciarenito "peletoidal" de cimento calcítico. Notar semelhança com o exemplo pedográfico da figura 5. Polarizadores paralelos. Fotomicrografia de Carozzi (1993). 


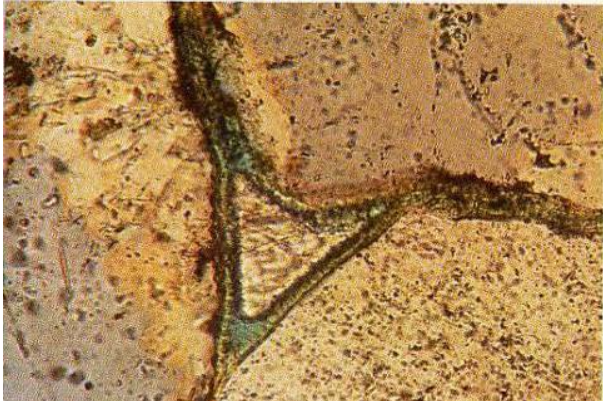

A

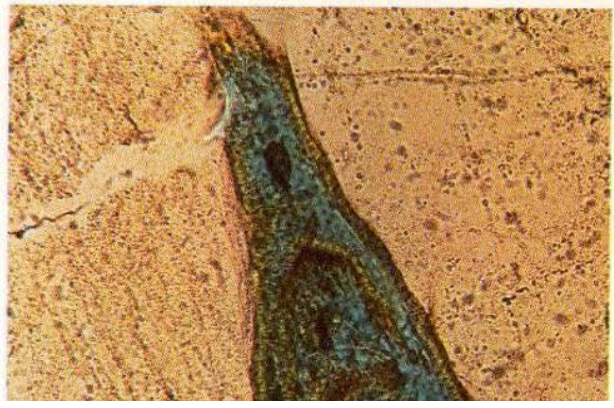

B $0.1 \mathrm{~mm}$ PL $0.1 \mathrm{~mm}$ PL

Figura 16 - Exemplos de cutículas de clorita (com cimento calcítico intersticial em A), formadas sob condições diagenéticas em quartzo arenito. Em pedografia, este tipo de feição seria designado revestimento (Stoops, 2003) ou cutan (Brewer, 1976). Fotomicrografia de Carozzi (1993).

Figura 17 - Exemplo de túbulo preenchido parcialmente por cristais neoformados pseudoespáticos de dolomita. Se esta feição ocorresse em solo, seria denominada como preenchimento denso incompleto, de acordo com Stoops (2003: p. 114). Fotomicrografia de Carozzi (1993).

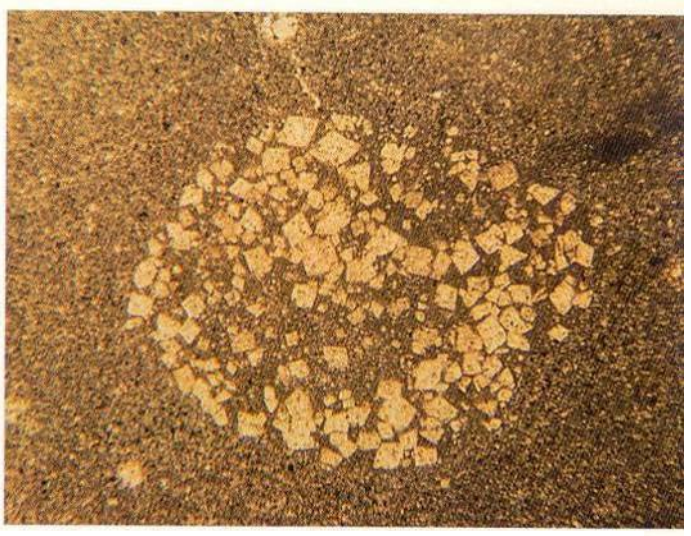

$0.25 \mathrm{~mm}$ 
As tabelasTabela 2 e Tabela 3 sintetizam as características descritivas usualmente reconhecidas em petrografia sedimentar e em pedografia, respectivamente.

Tabela 2 - Componentes e propriedades na descrição petrográfica de rochas sedimentares (ou sedimentos endurecidos), conforme proposto por Giannini (2006).

\begin{tabular}{|c|c|c|c|c|c|}
\hline & \multicolumn{2}{|c|}{ Componentes deposicionais } & \multicolumn{2}{|c|}{$\begin{array}{l}\text { Componentes pós- } \\
\text { deposicionais (diagenéticos) }\end{array}$} & \multirow{2}{*}{$\begin{array}{c}\begin{array}{c}\text { Produto pós- } \\
\text { deposicional } \\
\text { (diagenético) }\end{array} \\
\begin{array}{c}\text { Efeitos de } \\
\text { compactação }\end{array} \\
\end{array}$} \\
\hline & Arcabouço & Matriz & Cimento & $\begin{array}{l}\text { Porosidade } \\
\text { secundária }\end{array}$ & \\
\hline \multirow{3}{*}{ 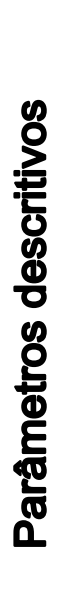 } & Mineralogia & Mineralogia & & \multirow{3}{*}{$\begin{array}{c}\text { Tipo } \\
\text { (dissolução, } \\
\text { moldes, } \\
\text { heterogeneidade } \\
\text { de } \\
\text { empacotamento, } \\
\text { corrosão, } \\
\text { sulcamento, } \\
\text { fraturas) e forma }\end{array}$} & \\
\hline & $\begin{array}{c}\text { Petrotrama } \\
\text { (segregação granular, } \\
\text { orientação, } \\
\text { imbricação, } \\
\text { empacotamento) } \\
\end{array}$ & $\begin{array}{c}\text { Tipologia } \\
\text { (protomatriz, } \\
\text { ortomatriz, } \\
\text { epimatriz, } \\
\text { pseudomatriz) } \\
\end{array}$ & Mineralogia & & Mecânica \\
\hline & $\begin{array}{l}\text { Textura (granulometria } \\
\text { modal, desvio padrão, } \\
\text { seleção } \\
\text { granulométrica, } \\
\text { esfericidade, } \\
\text { arredondamento) }\end{array}$ & $\begin{array}{c}\text { Textura } \\
\text { (clástica, } \\
\text { recristalizada) }\end{array}$ & $\begin{array}{c}\text { Textura } \\
\text { (hábito, } \\
\text { tamanho e/ou } \\
\text { cristalinidade } \\
\text { disposição } \\
\text { espacial em } \\
\text { relação ao } \\
\text { arcabouço) }\end{array}$ & & Química \\
\hline
\end{tabular}


Tabela 3 - Componentes e propriedades na descrição pedográfica (ou micromorfológica), conforme proposto por Stoops (2003).

\begin{tabular}{|c|c|c|c|}
\hline & $\begin{array}{c}\text { Pedofeições }^{3} \text { (feições } \\
\text { pedogenéticas) }\end{array}$ & \multicolumn{2}{|c|}{ Massa basal (groundmass) } \\
\hline \multirow{6}{*}{ 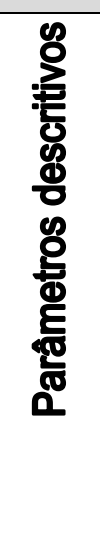 } & Natureza & \multicolumn{2}{|c|}{ Limite, razão e distribuição $\mathrm{g} / \mathrm{f}^{4}$} \\
\hline & Tamanho & Material grosso & Micromassa \\
\hline & Forma & $\begin{array}{l}\text { Mineralogia (natureza, } \\
\text { tamanho, freqüência, } \\
\text { padrão) }\end{array}$ & \multirow{3}{*}{$\begin{array}{c}\text { Natureza, cor, textura b (b- } \\
\text { fabric), transparência } \\
\text { (limpidity), cores de } \\
\text { interferência (propriedade } \\
\text { óptica) }\end{array}$} \\
\hline & Variabilidade & \multirow{2}{*}{ Material orgânico } & \\
\hline & Abundância & & \\
\hline & $\begin{array}{l}\text { Microestrutura e } \\
\text { porosidade }\end{array}$ & \multicolumn{2}{|c|}{$\begin{array}{c}\text { Material orgânico não incluso na massa basal nem } \\
\text { nas pedofeições }\end{array}$} \\
\hline \multirow{4}{*}{ 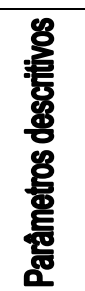 } & $\begin{array}{l}\text { Tipo (relação materiais } \\
\text { do solo x vazios) }\end{array}$ & \multicolumn{2}{|c|}{ Tipo (raízes, preenchimento de canais etc.) } \\
\hline & Tamanho & \multicolumn{2}{|c|}{ Grau de alteração } \\
\hline & Forma & \multicolumn{2}{|c|}{ Tamanho } \\
\hline & Distribuição & \multicolumn{2}{|c|}{ Padrão } \\
\hline
\end{tabular}

Nota-se, no exercício de comparação destas duas tabelas, que a lógica descritiva da petrografia difere substancialmente da pedografia. Em seções delgadas de sedimentos (ou rochas sedimentares), divide-se a observação em feições deposicionais e pós-deposicionais, e em seguida, descrevem-se o arcabouço e a matriz. Descritas as feições deposicionais, parte-se para a observação das feições pós-deposicionais (cimento, porosidade secundária e efeitos de compactação mecânica e química). No entanto, a distinção entre feições deposicionais e pós-deposicionais envolve uma dose intrínseca de interpretação. Como exemplo, pode-se mencionar a dificuldade clássica de distinguir matriz de argilominerais (proto e ortomatriz) de cimento de mesma constituição mineralógica, e porosidade primária de porosidade secundária.

${ }^{3}$ Exemplos de pedofeições são: revestimentos de argila (clay coatings de Stoops, 2003 e cutans de Brewer, 1976), nódulos (ou glaebules de Brewer, 1976) calcíticos, cristais de gipso euédricos, excrementos (fecal pellets de Brewer, 1976) da fauna do solo, "mosqueamento" goethítico (goethite mottles) e feições de passagem (canais) (Stoops, 2003).

${ }^{4} \mathrm{~g} / \mathrm{f}=$ grosso/fino $(c / f=$ coarse/fine $)$, relativo ao tamanho dos grãos, sendo que o limite entre grosso e fino é dado pelas necessidade e objetivos do estudo micromorfológico, pois, como afirma Stoops (2003), dada a grande diferença entre os materiais pedogenéticos, é preferível não adotar valor limítrofe único. 
Ainda em relação à comparação entre petrografia e pedografia, se for tomada uma seção delgada de solo, a primeira abordagem é a identificação do "arranjo" (fabric), semelhante à petrofábrica ou petrotrama da abordagem petrográfica. A descrição dos elementos de arranjo (elements of fabric, sensu Stoops, 2003) é de enfoque analítico, partindo das feições mais gerais (padrões de distribuição dos componentes no espaço) para as mais individuais (tamanho, forma, arredondamento, superfície de grão). Este padrão de observação é comum a muitos métodos microscópicos, inclusive a petrografia sedimentar, e tem-se mostrado eficiente ao longo dos anos. Porém, diferente da petrografia sedimentar, a estrutura dos componentes do solo não é organizada em feições sin e pós-deposicionais e tampouco na relação arcabouço e matriz, mas sim em feições pedogenéticas (pedofeições), estrutura (microestrutura e padrão de porosidade) e massa basal (que agrupa as características composicionais de praticamente todos os outros componentes). Cada componente é descrito individualmente, agrupando características estruturais, texturais e composicionais para cada parâmetro (Tabela 3). A inclusão de muitos detalhes acerca de cada parâmetro de arranjo conduz o pedógrafo a uma abordagem analítica minuciosa em que se perde, pelo menos momentaneamente, a noção de integração ou síntese com as demais feições descritivas.

Em suma, é como descrever várias vezes a mesma seção, com vários focos de aproximação (zooms in), procurando observar características diferentes para cada escala de focagem ou zoom, o que resulta em uma estrutura descritiva complexa, que se sobrepõe em uma convulsão terminológica (por exemplo, distribuição g/f e microestrutura).

Em contrapartida, a pedografia é a melhor técnica de descrição de solo, pois só ela possui riqueza descritiva suficiente para abrigar as inúmeras feições pedogenéticas, em oposição à petrografia, pobre em termos descritivos, principalmente no que se refere a feições pós-deposicionais não diagenéticas. Tanto é que a petrografia de paleossolos muito empresta da descrição micromorfológica de solos (Retallack, 2001).

Em vista das consideráveis diferenças entre feições descritivas reconhecidas ou enfatizadas na petrografia e na pedografia, não há consenso terminológico para a descrição microscópica de solos e de sedimentos. Ambas as disciplinas adotam termos, às vezes em comum, mas que diferem em seus significados, não sendo possível sequer a correlação direta de parâmetros de descrição. Por exemplo, textura para os pedólogos pode significar "a constituição física de um material pedogenético, expresso por sua estrutura e pelo grau de cristalinidade das partículas sólidas; arranjo (fabric) é parte da estrutura, que por sua vez é parte da textura (Brewer, 1976)". Já para a geologia sedimentar, "a textura refere-se ao tamanho, forma e arranjo dos componentes minerais de uma rocha (Pettijohn, 1975)". Outros 
autores, ainda em sedimentologia, consideram textura como propriedade física de grão individual e trama ou arranjo como orientação espacial dos grãos uns em relação aos outros (Suguio 1980). Enquanto isso, a estrutura, em sedimentologia, refere-se à manifestação, visível a olho nu, da segregação espacial de grãos ou de cimento.

Porém, apesar das diferenças, as duas técnicas possuem uma área de interface ou sobreposição, que reside na análise das feições pós-deposicionais. Na óptica da petrografia sedimentar, as feições pós-deposicionais incluem os produtos de processos diagenéticos e de alteração superficial penecontemporânea à deposição. Na óptica da pedografia de solos formados sobre sedimentos, abrangem a quase totalidade das feições de interesse.

\subsubsection{Aplicações em arqueologia}

A necessidade da arqueologia em adaptar as técnicas microscópicas preexistentes está ligada ao caráter pontual ou dirigido da demanda desta ciência, qual seja, a busca do entendimento de como o homem atuou em determinado sítio; o interesse é centrado portanto na procura de vestígios da presença humana, tal como ocorreria a um investigador forense na cena do crime.

Além da inferência de estruturas com significado interpretativo específico, a micromorfologia, em arqueologia, pode ser utilizada como instrumento para: compreensão de processos formativos de sítios arqueológicos (Gebhardt e Langohr, 1999; Albert et al., 1999; Creemings, 2003; Villagrán, 2008); entendimento dos processos pós-deposicionais que obliteram o registro arqueológico (Schiegl et al., 1996; Goldberg e Arpin, 1999; Canti, 2003b); relacionamento entre ambiente deposicional e ocupação (Courty e Fédorof, 1985; Mallol, 2006); procura de indícios de uso do solo para agricultura (Macphail et al., 1990); e determinação de proveniência de restos humanos ósseos (Huckleberry et al., 2003).

A microscopia de sedimentos arqueológicos é especialmente útil na tentativa de delimitação dos processos pós-deposicionais. Em arqueologia, entende-se por processo pósdeposicional aquele que oblitera o registro da ação humana, seja por diagênese, seja por pedo, fito ou bioturbação. Estes processos podem ser detectados e caracterizados com o auxílio das técnicas microscópicas discutidas nos itens anteriores. A detecção de processos pós-deposicionais por meio destas técnicas permite ao estudo arqueológico maior confiabilidade na interpretação do registro arqueológico, à medida que possibilita sua contextualização deposicional. 


\subsubsection{Particularidades da micromorfologia aplicada a depósitos arqueológicos}

O foco da pedografia aplicada a depósitos sedimentares é a gênese do solo, e, portanto, recai em processos essencialmente pós-deposicionais; já a petrografia sedimentar é voltada tanto a processos deposicionais como a pós-deposicionais (incluindo modificações penecontemporâneas na interface deposicional e modificações no material soterrado, i.e., diagenéticas), o que a torna mais abrangente, principalmente para aplicações arqueológicas.

A pedografia e a petrografia sedimentar devem ser adaptadas conjuntamente, em sinergia, para a utilização em arqueologia, de modo que as vantagens de cada técnica sejam exploradas ao máximo e as respectivas limitações sejam superadas. Por exemplo, a descrição de processos de transporte, no contexto de estudos arqueológicos, pode ser feita com mais eficiência pela petrografia sedimentar, voltada a esse objetivo, de que pela pedografia.

As feições microscópicas de interesse em arqueologia são pontuais (centradas em evidências da ocupação humana). Este fato não é suficiente, porém, para justificar ignorar-se a descrição de demais atributos do sedimento; pelo contrário, a análise destes atributos pode fornecer informações tafonômicas relevantes, ou mesmo imprescindíveis, para a interpretação de processos culturais.

\subsubsection{Uma proposta de abordagem integrada}

Uma tentativa de sinergia entre as duas técnicas, em estudos de sedimentos e solos arqueológicos, por exemplo, poderia ser feita se fosse utilizada a estrutura da petrografia (Tabela 2), com a adição das minúcias descritivas da pedografia. Um exemplo pode ser esboçado da seguinte forma:

a. separa-se a amostra em feições deposicionais e pós-deposicionais;

b. descreve-se a microestrutura e a porosidade de forma a abranger toda a amostra;

c. identificam-se em seguida os elementos do arcabouço e da matriz, utilizando o limite $g / f$;

d. descreve-se a textura do arcabouço e da matriz, utilizando os parâmetros descritivos do "material grosso" e micromassa da pedografia;

e. identificam-se as pedofeições como um dos componentes pós-deposicionais agregando-as às descrições das feições e produtos diagenéticos da petrografia. 


\subsection{Estrato, camada e lâmina: definições adotadas}

Nota-se na literatura geológica alguma imprecisão e multiplicidade de significados na utilização dos termos estrato, camada e lâmina. Como se trata de conceitos extremamente usuais na caracterização de fácies deposicionais em geologia, e, ao mesmo tempo, bastante utilizados em arqueologia, a definição prévia do sentido em que serão utilizados neste trabalho é metodologicamente imprescindível.

Estrato, do latim stratum (plural strata) é o termo aplicado por Campbell (1967: p 8) a uma fatia deposicional (layer) de rocha ou sedimento que é visual ou fisicamente separável (distinta) das fatias acima e abaixo por superfícies de estratificação (Figura 18).

Camada (bed em inglês) é definida por Campbell (1967: p 8) como um estrato que revela o fatiamento deposicional (layer) principal de uma rocha. Uma camada, segundo mesmo autor, não tem limite de espessura, não necessita diferir litologicamente de suas adjacentes e pode ser composta por mais de um tipo de rocha. Possui propriedades de unidade cronoestratigráfica de curta duração e pouca abrangência espacial (Campbell, 1967: p 8), isto é, tem hierarquia litoestratigráfica inferior a membro.

Lâmina (do latim laminæ) é o termo aplicado ao menor estrato em escala de afloramento (megascopic), delimitado por superfícies de laminação; a série de lâminas (laminaset) consiste em um grupo de lâminas conformes, que formam uma estrutura distinta inserida em uma camada (bed) (Campbell, 1967: p 8).

Para Campbell (1967), os termos stratum e layer são sinônimos, e são utilizados em seu texto para se referir de forma genérica a camadas (bed) e lâminas, bem como a séries de camadas e de lâminas. 


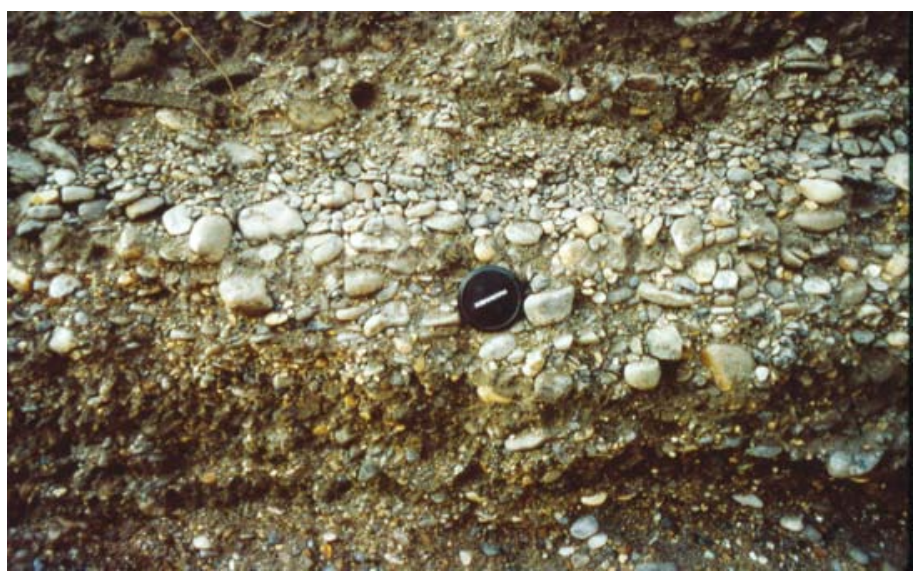

A

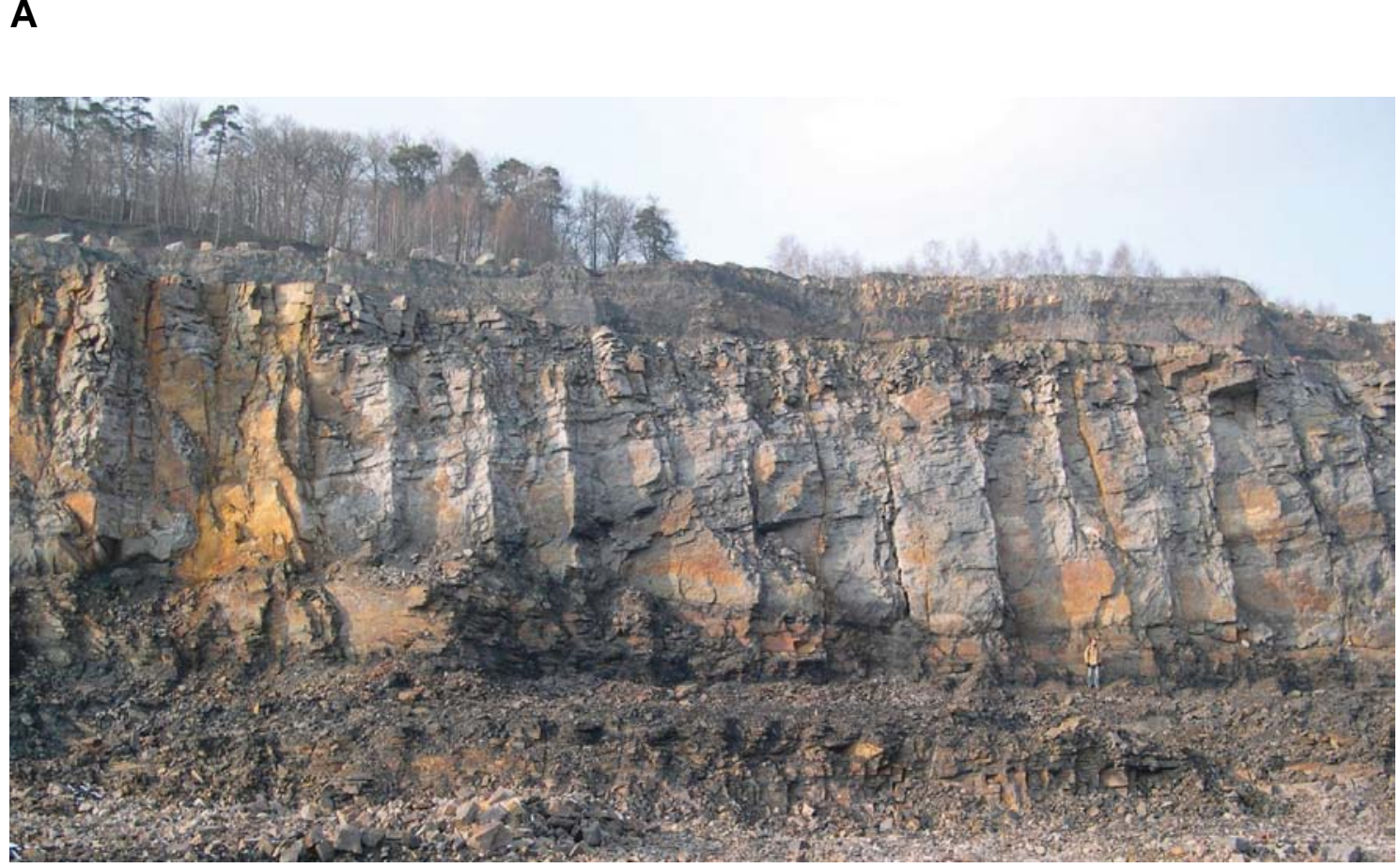

B
Figura 18 - Exemplos de estratos. (A) Estrato tabular formado por seixos, possível de ser individualizado, mesmo com pouca variação composicional; notar gradação interna inversa-normal. (B) Depósitos de canal fluvial (Período Carbonífero, noroeste da Alemanha) mostrando estratos tabulares inclinados com mergulho para a esquerda. Fotos retiradas de Walker (2006), que utilizou originalmente o termo estrato (stratum). 


\section{MÉTODOS DE EXECUÇÃO}

\subsection{Atividades de campo}

\subsubsection{Descrição e coleta de amostras}

A amostragem do sítio Jabuticabeira II concentrou-se nas seções verticais dos lócus 1 e 2 (UTM 0699466/6835678), antigas frentes de lavra de calcário, exumadas pela equipe arqueológica do Museu de Arqueologia e Etnologia da USP em 1997, e devidamente limpas na ocasião da amostragem. Estes lócus situam-se na porção noroeste do sambaqui (Figura 19).

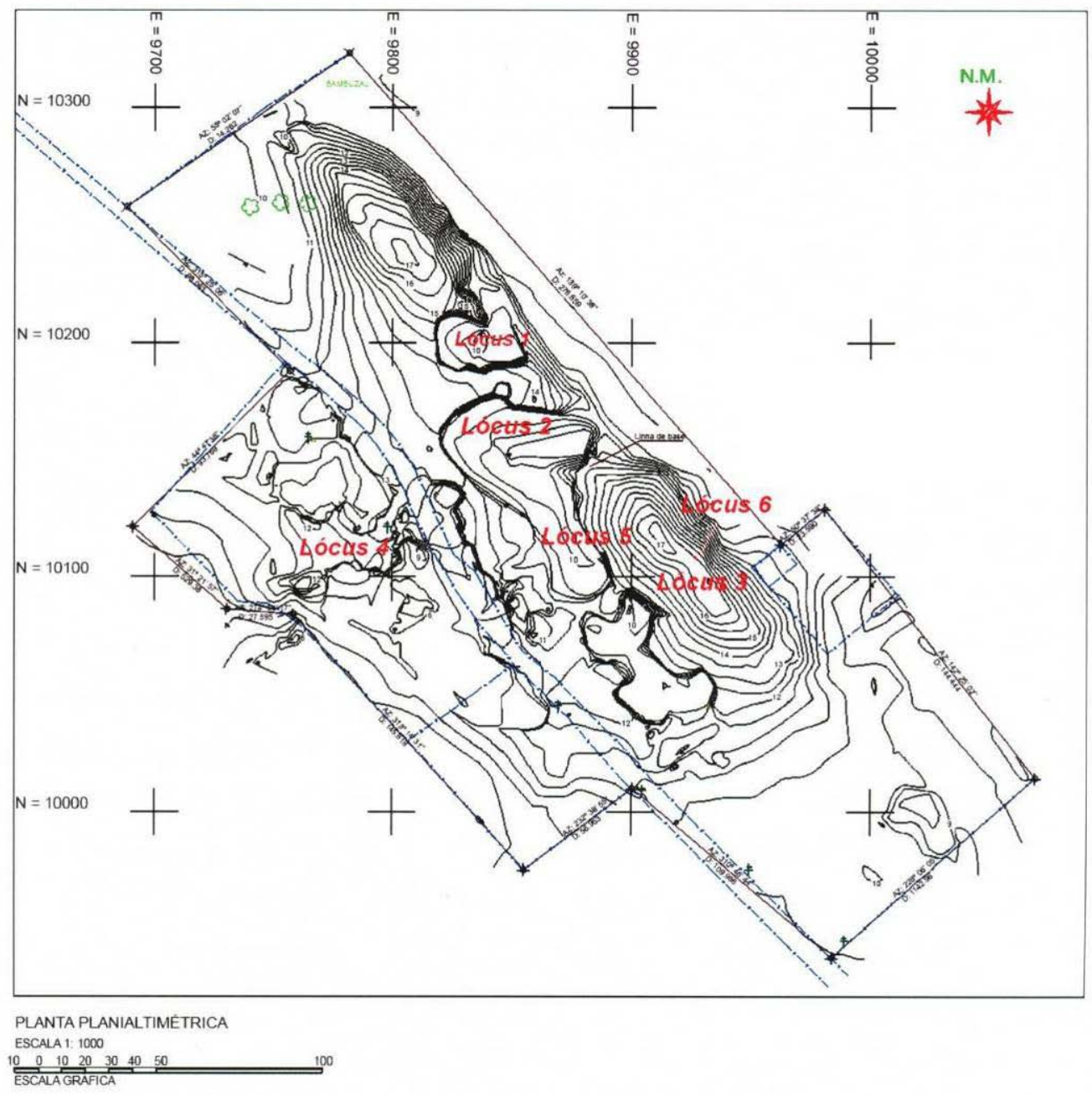

Figura 19 - Localização dos lócus 1 e 2 de levantamento arqueológico (MAE-USP), em planta planialtimétrica no sambaqui Jabuticabeira II. Modificado de Villagrán (2008). 
As amostras foram coletadas com controle faciológico, uma por fácies previamente determinada. A coleta de mais de uma amostra de mesma fácies ocorreu apenas nos casos de duas fácies, "camadas funerárias" e "terra preta", do sítio Jabuticabeira II. A primeira destas fácies corresponde a lâminas extensas e delgadas (menores que $30 \mathrm{~cm}$ ) com marcas cônicas, constituintes de superfícies delimitantes (lâminas "funerárias" com marca cônica). Nela, foi amostrada a maior parte das recorrências observadas numa mesma seção colunar (Figuras 20 a 22). A segunda corresponde a fácies de "terra preta" espessa (até $2 \mathrm{~m}$ ), com líticos, rica em ossos (fácies "terra preta" com líticos e ossos), onde foi coletada uma seqüência vertical contínua de amostras de $10 \mathrm{~cm}$ de altura, cada uma (Figura 23).

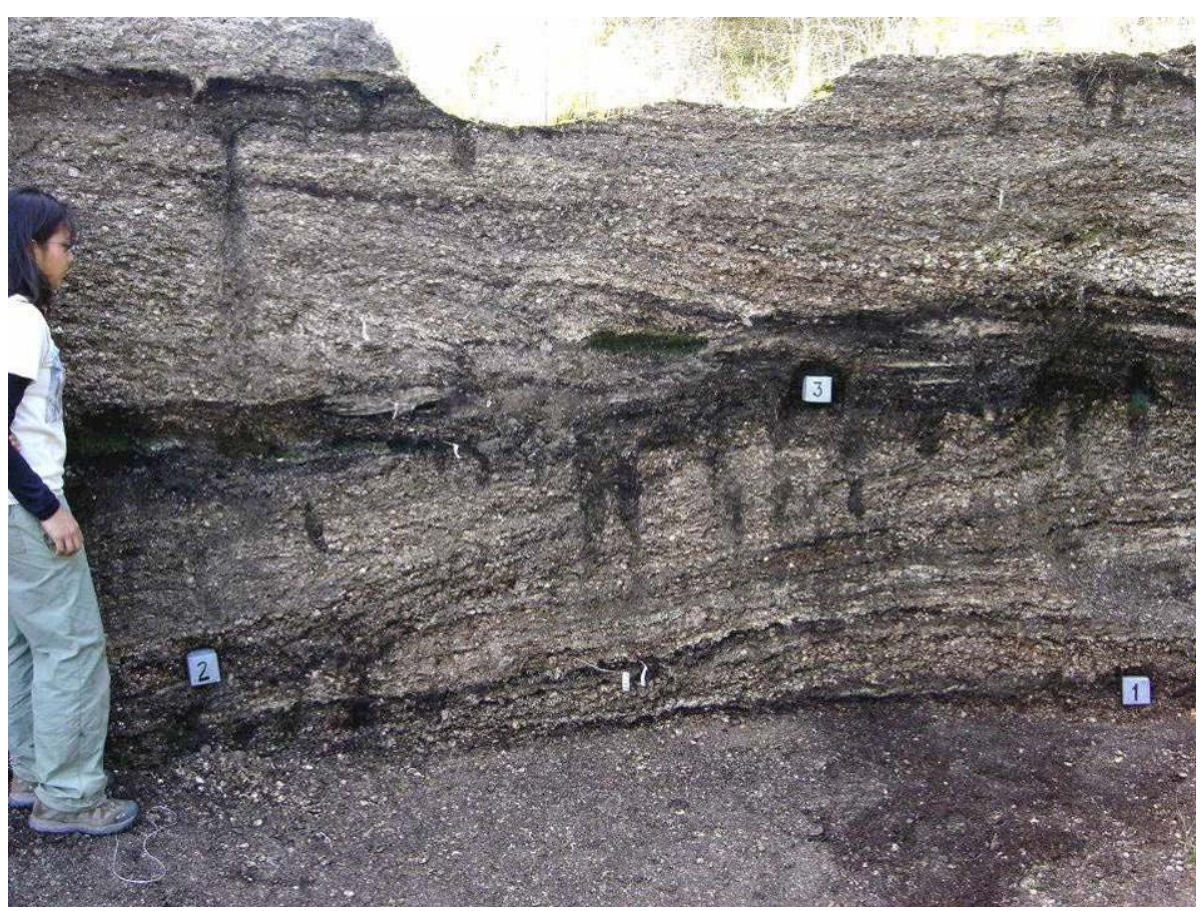

Figura 20 - Amostragem de sedimentos indeformados (caixas de metal) e deformados (retirados com espátula, no arredor de cada caixa) nas recorrências das lâminas "funerárias" (fácies Lc) do sambaqui Jabuticabeira II, lócus 2. Amostras indicadas na foto: JB-01TP, JB-02TP e JB-03TP (Tabela 4). Seção vertical (antiga frente de lavra, exumada) com orientação $\mathrm{N} 80^{\circ}$. 
Figura 21 - Amostragem de sedimentos indeformados (caixas de metal) e deformados (retirados com espátula no arredor de cada caixa) nas recorrências das lâminas "funerárias" (fácies Lc) do sambaqui Jabuticabeira II, lócus 2. Amostras indicadas na foto: JB04TP e JB-05TP (Tabela 4). Seção vertical (antiga frente de lavra, exumada) com orientação $\mathrm{N} 80^{\circ}, 1 \mathrm{~m}$ a $W$ do local da figura anterior.
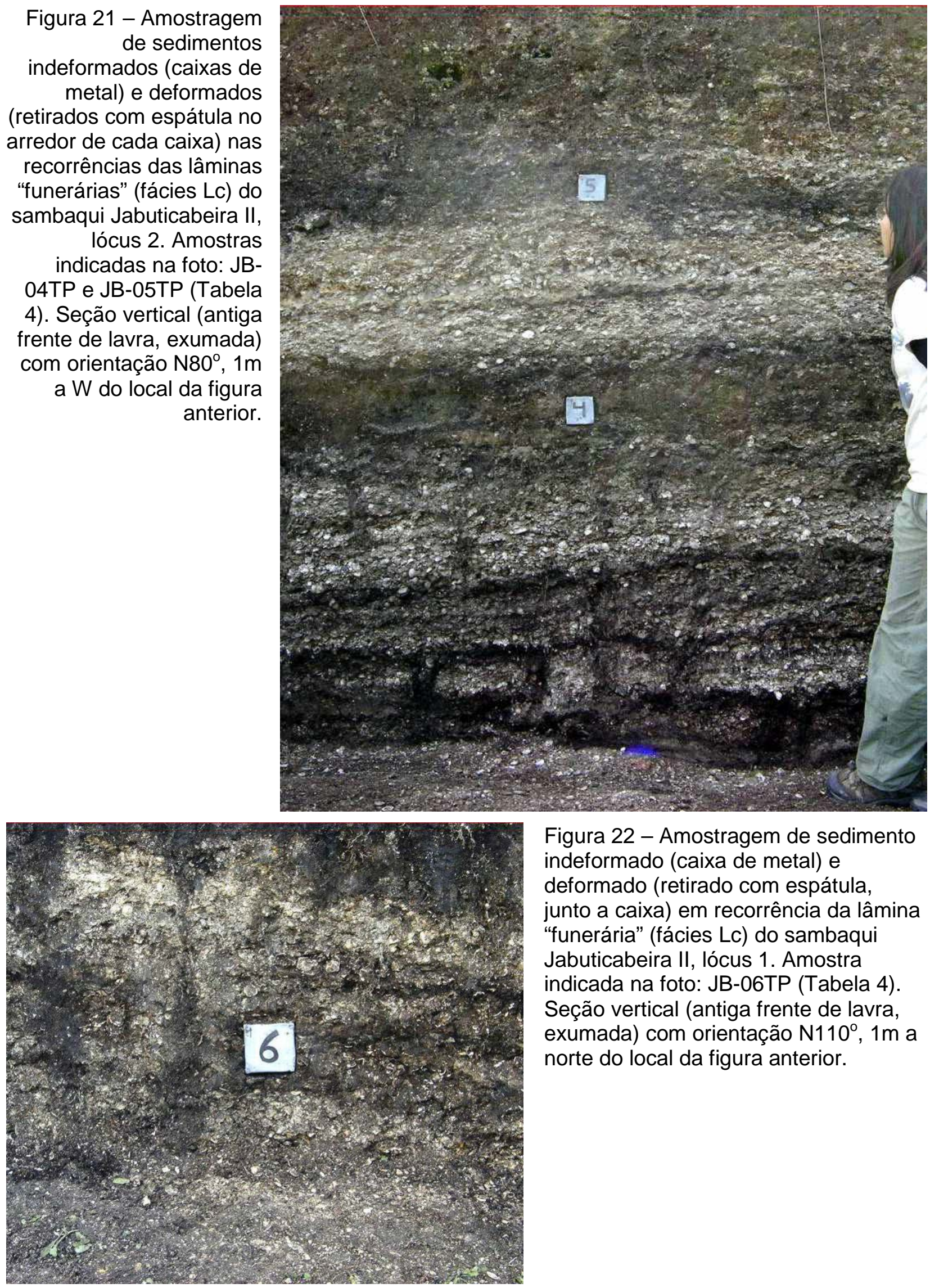

Figura 22 - Amostragem de sedimento indeformado (caixa de metal) e deformado (retirado com espátula, junto a caixa) em recorrência da lâmina "funerária" (fácies Lc) do sambaqui Jabuticabeira II, lócus 1. Amostra indicada na foto: JB-06TP (Tabela 4). Seção vertical (antiga frente de lavra, exumada) com orientação $\mathrm{N} 110^{\circ}, 1 \mathrm{~m}$ a norte do local da figura anterior. 


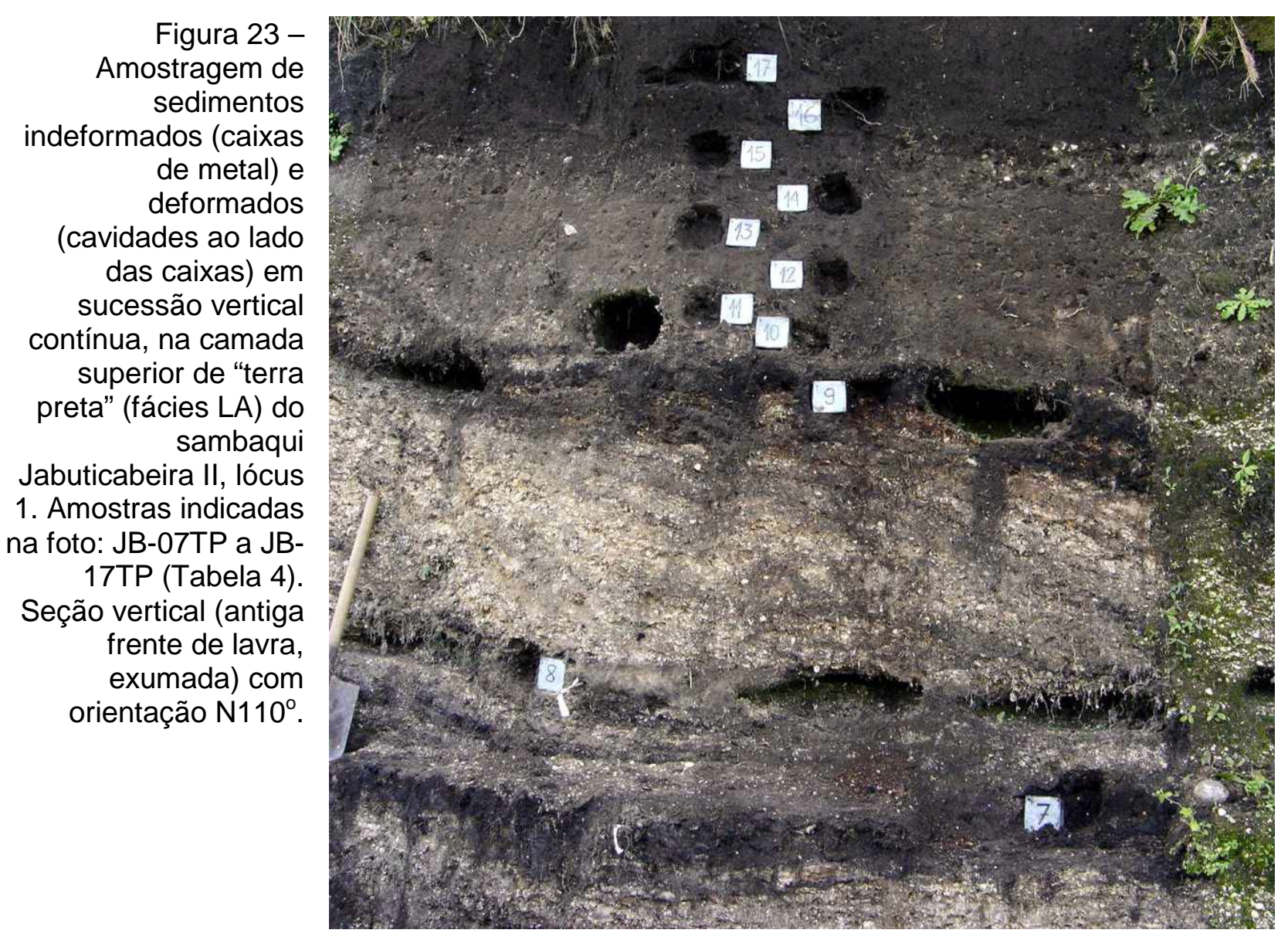

Os sedimentos supostamente geogênicos da área circunvizinha ao sítio foram amostrados através de trincheiras, conforme localização indicada na Figura 24. 


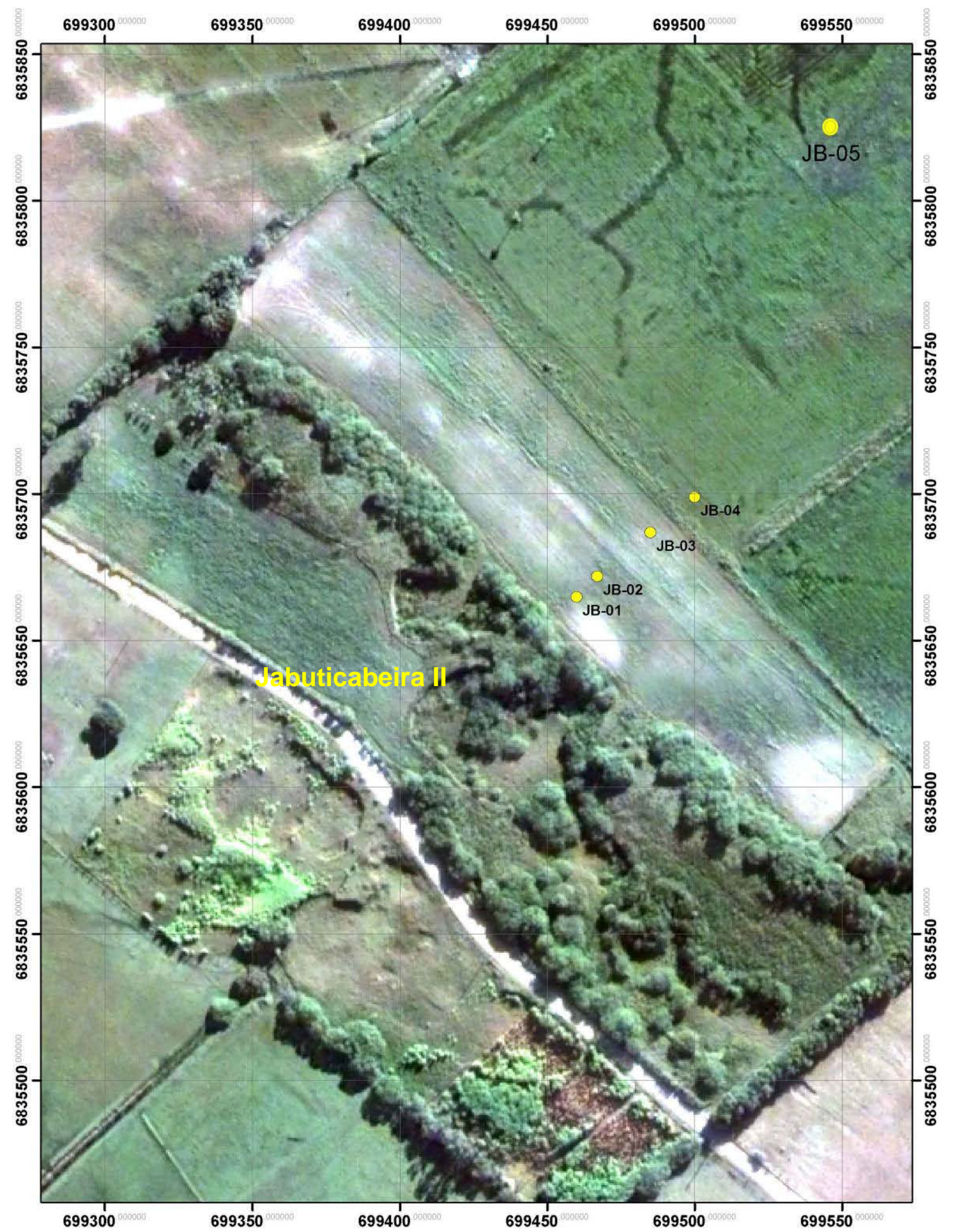

Figura 24 - Localização das trincheiras próximas ao sambaqui Jabuticabeira II. Quadrículas em coordenadas UTM com intervalo de 50 m. Imagem Landsat, 2006. 
A amostragem do sítio Encantada III (UTM 0703858/6831507) repetiu o mesmo padrão de coleta do sítio Jabuticabeira II. Porém, a diferença entre a complexidade estratigráfica presente no Jabuticabeira II e a aparente simplicidade do Encantada III refletiu-se na quantidade de amostras. Assim, neste segundo sambaqui foram coletadas apenas duas amostras: uma da fácies arenosa e outra da fácies sobreposta de "terra preta" (Figura 4 A e B).

As amostras de sedimentos geogênicos na área circunvizinha ao sambaqui Encantada III foram retiradas de uma trincheira (GS-03) na periferia noroeste do sambaqui e em vala aberta pela atividade de carcinicultura (GS-01) distante do sambaqui aproximadamente $50 \mathrm{~m}$ (Figura 25).

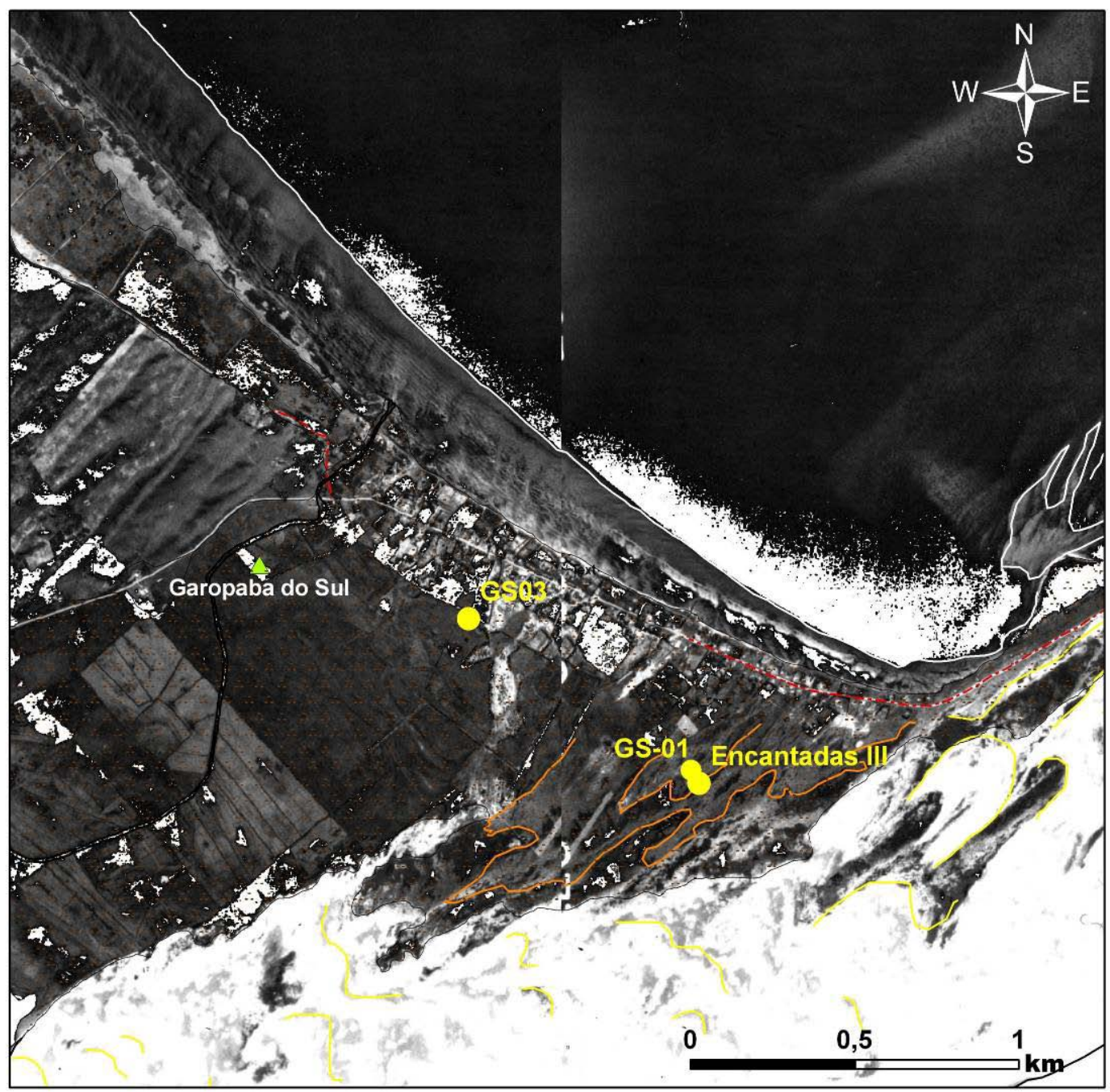

Figura 25 - Mosaico de fotos aéreas com a localização da trincheira GS03 e vala de carcinicultura GS-01, próximo do sambaqui Encantada III. Foto aérea de $1977 / 78$. 
O sambaqui Carniça III (UTM 0714579/6840392) possui sucessão estratigráfica similar a do sítio Encantada III, com duas fácies, a inferior, arenosa pura, e a superior, mais rica em argila e matéria orgânica ("terra preta"). Desse modo, o sistema de amostragem foi análogo ao daquele sítio, com retirada de duas amostras, uma de cada fácies (Figura $5 \mathrm{~A}$ e B).

Para a coleta de sedimentos geogênicos nas vizinhanças do sambaqui Carniça III, abriu-se trincheira dele distante aproximadamente 50 m (CV-01: UTM 713901/6840939). Adicionalmente, foram utilizados os resultados sedimentológicos de amostras coletadas ao largo da planície de cordões litorâneos de Campos Verdes, obtidos por Tanaka (2007) e Tanaka et al. (inédito) (Figura 26).

De modo geral, foram coletados dois tipos de amostras: indeformadas e deformadas. As amostras indeformadas são as destinadas a micromorfologia, conforme a Tabela 4. Foram retiradas utilizando recipientes de metal de base quadrada $(8 \times 8 \mathrm{~cm}$ de lado por $10 \mathrm{~cm}$ de altura), colocados com a abertura voltada para a seção vertical do sambaqui e martelados até o enterramento completo. As amostras indeformadas, destinadas à realização dos demais ensaios, foram coletadas em massa de 1 a 2 kg, com o auxílio de espátula ou manualmente, e acondicionadas em sacos plásticos. 


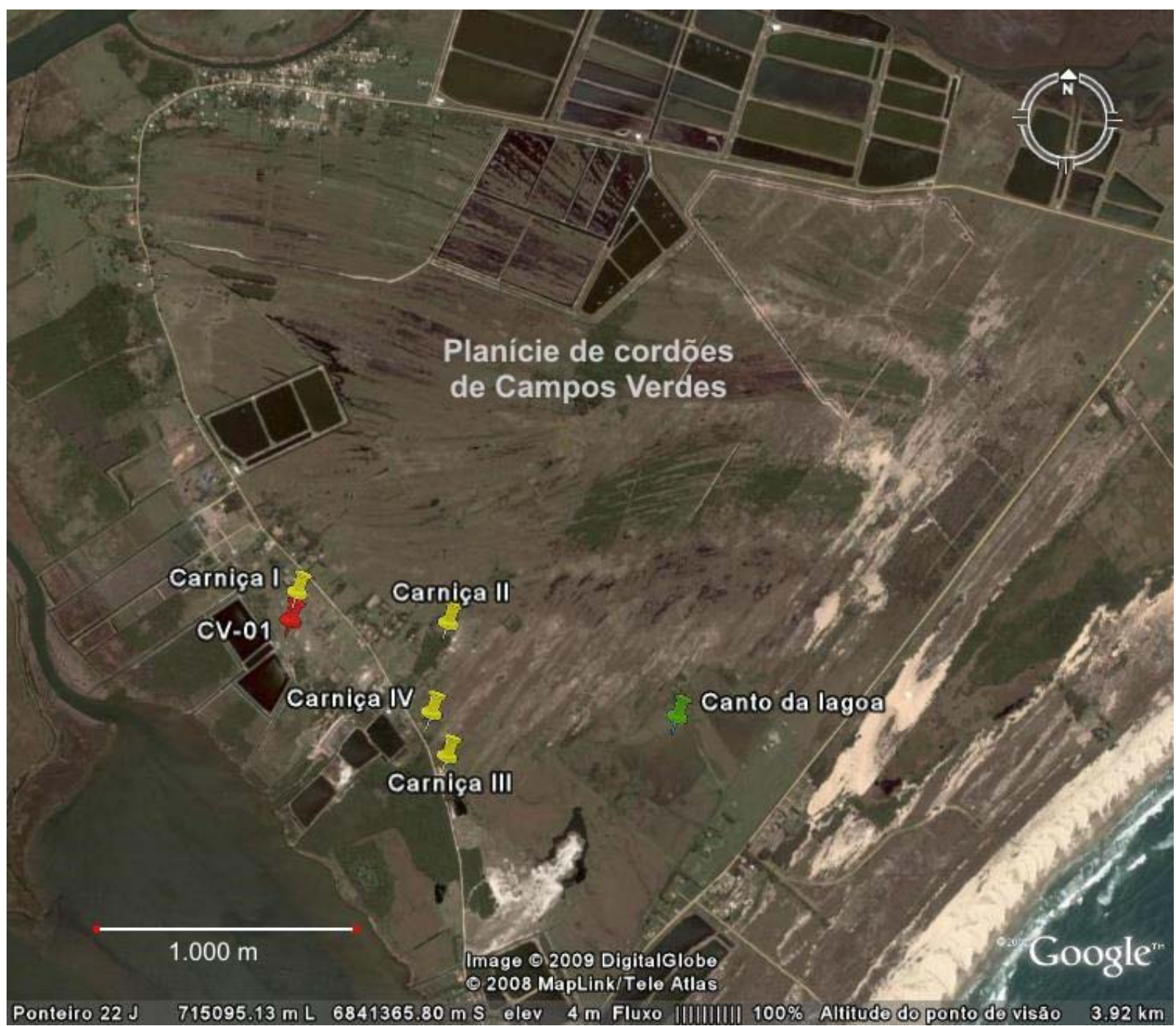

Figura 26 - Localização dos sambaquis Carniça I a IV e Canto da Lagoa, e a trincheira CV-01, em relação à planície de cordões de Campos Verdes.

As descrições das fácies reconhecidas nas seções verticais seguiram os princípios de análise de fácies definidos no item 3.2, tendo os seguintes parâmetros principais de observação de campo:

a. Forma externa - tabular, lenticular (plano-côncava, plano-convexa ou côncavoconvexa), cônica ou cuneiforme;

b. Contatos - abruptos ou transicionais;

c. Porte - estimativa de espessura e extensão lateral;

d. Constituição granulométrica - cascalho, areia ou silte/argila;

e. Composição quanto ao material construtivo - conchas, ossos, madeira, cinzas, carvão, sedimento intraclástico; 
f. Estruturas - estratificações (camadas, séries de lâminas e lâminas) sub-horizontais ou inclinadas, covas, marcas cônicas ("marcas de estaca"), aspecto maciço (ausência de estrutura aparente);

g. Trama - paralelismo ou imbricação (de grãos alongados), gradação (inversa ou normal), segregação granular (quanto a tamanho, forma, composição ou empacotamento);

h. Posição espacial - de ocorrência e/ou recorrência, em relação à estratigrafia e à geografia;

i. Objetos líticos.

A representação dos perfis estudados foi executada no formato de seção colunar e seção geológica, ferramentas de representação gráfica que permitem sintetizar quantidade satisfatória de informações, para os objetivos deste estudo, e maior agilidade de correlação e interpretação de fácies.

\section{Nomenclatura de fácies}

Para identificar as fácies descritas, foi utilizada codificação, consagrada no meio geológico, de modo a permitir identificação rápida de constituição e estruturas características de cada unidade.

No aspecto constitutivo, simbolizado através de letras maiúsculas, optou-se por privilegiar a granulação: A para areia, C para cascalho, L para lutáceo. Estes códigos também foram utilizados duplicadamente, nos casos em que houve necessidade de distinguir fácies com o mesmo componente granulométrico principal, por exemplo "LA" para distinguir "lama arenosa" de lama (L). As estruturas foram identificadas com uma a duas letras minúsculas: $p$ para estratificação plano-paralela de caráter subhorizontal, $\ell$ para laminação, b para bolsões ou clastos de areia ou lama ("bolas" de lama ou areia) e c para marcas cônicas.

\subsubsection{Códigos de amostragem}

As amostras coletadas foram enumeradas conforme sistema apresentado a seguir.

As lâminas "funerárias" e "terra preta" encontradas no sítio Jabuticabeira II (fácies Lc e LA, respectivamente) foram identificadas com código JB-NN-TP, onde NN corresponde a uma numeração sequencial de amostragem (de 01 até 17 , da base para o topo) e TP significa "terra preta". Cada exemplar das fácies descritas em campo correspondentes às camadas ricas em concha foi designado, de modo análogo, pelo código JB-NN-C (C de 
concha). Para agrupamentos de amostras, as fácies Lc e LA receberam a nomenclatura Jab TP, e as conchíferas, Jab concha.

As amostras do sambaqui Carniça III possuem código CV-TP, para a amostra retirada da respectiva fácies "terra preta", e CV-Areia, para a fácies arenosa inferior. O código CV é alusão à localidade de Campos Verdes, nome hoje em dia mais utilizado para a região onde se situa o sambaqui. Para agrupamentos de amostras, a fácies "terra preta" recebeu a nomenclatura CV TP, e a arenosa, CV areia.

As amostras coletadas no sambaqui Encantada III possuem código GS-TP para a amostra retirada da respectiva fácies "terra preta", e GS-Areia, para a respectiva fácies arenosa. O código GS é alusão à localidade de Garopaba do Sul, onde se situa o sambaqui. Para agrupamentos de amostras, a fácies "terra preta" recebeu a nomenclatura GS TP, e a arenosa, GS areia.

As áreas de sedimentos geogênicos circunvizinhas aos sítios foram amostradas através de trincheiras ou poços. As amostras dos poços próximos ao sambaqui Jabuticabeira II possuem códigos JB-05- $\alpha$ a y para coletas em p̧o de $1 \times 1 \mathrm{~m}$ e JB -NN- $\alpha$ e $\beta$ para as trincheiras (Figura 24). O agrupamento de amostras dos sedimentos geogênicos do entorno do Jabuticabeira II recebeu a nomenclatura Jab Geo. As amostras coletadas em trincheira próximo ao sambaqui Carniça I possuem código CV-01- $\alpha$ a $\delta$ (figura Figura 26). O agrupamento de amostras dos sedimentos geogênicos do entorno do Carniça I recebeu a nomenclatura CV Geo. Para as amostras coletadas próximas ao sambaqui Encantada III, utilizou-se a designação GS-01, para amostra coletada em parede de vala de drenagem aberta pela atividade de carcinicultura (Figura 25), e código GS-03- $\alpha$ a $\delta$ para as amostras coletadas em trincheira. O agrupamento de amostras dos sedimentos geogênicos do entorno do Encantada III recebeu a nomenclatura GS Geo.

\subsection{Atividades de laboratório}

As técnicas analíticas descritas a seguir foram selecionadas, de acordo com a natureza das amostras, de forma a atender aos objetivos propostos neste trabalho. Na Tabela 1, encontram-se listadas as técnicas utilizadas para cada amostra coletada. 
Tabela 4 - Listagem das amostras coletadas e as análises a que foram submetidas.

\begin{tabular}{|c|c|c|c|c|c|c|c|c|c|c|}
\hline Amostra & $\begin{array}{c}\text { Local de } \\
\text { amostragem }\end{array}$ & $A G^{5}$ & $\mathrm{CO}_{3}{ }^{5}$ & $\mathrm{MO}^{5}$ & $M P^{5}$ & Lupa $^{5}$ & $\mathrm{Mic}^{5}$ & $\delta^{13} C^{5}$ & ${ }^{14} C^{5}$ & MEV \\
\hline $\begin{array}{l}\text { JB-01C (lâminas } \\
\text { amareladas) } \\
\text { Fácies Al }\end{array}$ & $\begin{array}{l}\text { Jabuticabeira II } \\
\text { lócus } 2\end{array}$ & $X$ & $X$ & $x$ & $\bullet$ & $X$ & & & & \\
\hline $\begin{array}{c}\text { JB-02C (areia fina } \\
\text { a m. fina) Fácies } \\
\text { Al }\end{array}$ & $\begin{array}{l}\text { Jabuticabeira II } \\
\text { lócus } 2\end{array}$ & $\mathrm{x}$ & $\mathrm{X}$ & $\mathrm{X}$ & $\bullet$ & 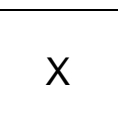 & & & & \\
\hline $\begin{array}{l}\text { JB-03C Fácies Cl } \\
\text { (concha inteira) }\end{array}$ & $\begin{array}{l}\text { Jabuticabeira II } \\
\text { lócus } 2\end{array}$ & $x$ & $x$ & $x$ & $\bullet$ & $x$ & & & & \\
\hline $\begin{array}{c}\text { JB-04C Fácies } \\
\text { CLb } \\
\end{array}$ & $\begin{array}{l}\text { Jabuticabeira II } \\
\text { lócus } 2\end{array}$ & $X$ & $\mathrm{x}$ & $\mathrm{X}$ & $\bullet$ & X & & & & \\
\hline JB-05C Fácies C $\ell$ & $\begin{array}{c}\text { Jabuticabeira II } \\
\text { lócus } 1 \text { e } 2\end{array}$ & $\mathrm{x}$ & $\mathrm{X}$ & $\mathrm{X}$ & $\bullet$ & $x$ & & & & \\
\hline JB-06C Fácies A & $\begin{array}{l}\text { Jabuticabeira II } \\
\text { lócus } 2\end{array}$ & $X$ & $X$ & $x$ & $\bullet$ & $x$ & & & & \\
\hline JB-07C Fácies L & $\begin{array}{l}\text { Jabuticabeira II } \\
\text { lócus } 2\end{array}$ & $X$ & $X$ & $X$ & $\bullet$ & $x$ & & & & \\
\hline $\begin{array}{c}\text { JB-08C Fácies } \\
\text { CAl }\end{array}$ & $\begin{array}{l}\text { Jabuticabeira II } \\
\text { lócus } 2\end{array}$ & $x$ & $x$ & $x$ & $\bullet$ & $x$ & & & & \\
\hline $\begin{array}{c}\text { JB-09C Fácies } \\
\text { CL } \ell\end{array}$ & $\begin{array}{l}\text { Jabuticabeira II } \\
\text { lócus } 1\end{array}$ & $X$ & $\mathrm{X}$ & $\mathrm{X}$ & $\bullet$ & X & & & & \\
\hline JB-10C Fácies Ap & $\begin{array}{l}\text { Jabuticabeira II } \\
\text { lócus } 1\end{array}$ & $X$ & $X$ & $x$ & $\bullet$ & $x$ & & & & \\
\hline $\begin{array}{c}\text { JB-01TP Fácies } \\
\text { Lc }\end{array}$ & $\begin{array}{l}\text { Jabuticabeira II } \\
\text { lócus } 2\end{array}$ & $\mathrm{X}$ & $x$ & $x$ & $x$ & $x$ & $x$ & $x$ & & $x$ \\
\hline $\begin{array}{l}\text { JB-02TP Fácies } \\
\text { Lc }\end{array}$ & $\begin{array}{l}\text { Jabuticabeira II } \\
\text { lócus } 2\end{array}$ & $x$ & $x$ & $\mathrm{X}$ & $X$ & $x$ & $x$ & $x$ & & \\
\hline $\begin{array}{c}\text { JB-03TP Fácies } \\
\text { Lc }\end{array}$ & $\begin{array}{l}\text { Jabuticabeira II } \\
\text { lócus } 2\end{array}$ & $\mathrm{x}$ & $\mathrm{X}$ & $x$ & $x$ & $x$ & $x$ & $x$ & & \\
\hline $\begin{array}{c}\text { JB-04TP Fácies } \\
\text { Lc }\end{array}$ & $\begin{array}{l}\text { Jabuticabeira II } \\
\text { lócus } 2\end{array}$ & $x$ & $x$ & $x$ & $x$ & $x$ & $x$ & $x$ & & $x$ \\
\hline $\begin{array}{c}\text { JB-05TP Fácies } \\
\text { LC }\end{array}$ & $\begin{array}{l}\text { Jabuticabeira II } \\
\text { lócus } 2\end{array}$ & $X$ & $X$ & $X$ & • & $X$ & $X$ & $x$ & & \\
\hline $\begin{array}{c}\text { JB-06TP Fácies } \\
\text { Lc }\end{array}$ & $\begin{array}{l}\text { Jabuticabeira II } \\
\text { lócus } 1\end{array}$ & $x$ & $X$ & $x$ & $x$ & X & X & $x$ & & \\
\hline $\begin{array}{c}\text { JB-07TP Fácies } \\
\text { Lc }\end{array}$ & $\begin{array}{l}\text { Jabuticabeira II } \\
\text { lócus } 1\end{array}$ & $x$ & $x$ & $\mathrm{x}$ & $\mathrm{X}$ & $x$ & $x$ & $x$ & & \\
\hline $\begin{array}{c}\text { JB-08TP Fácies } \\
\text { Lc }\end{array}$ & $\begin{array}{l}\text { Jabuticabeira II } \\
\text { lócus } 1\end{array}$ & $X$ & $X$ & $X$ & $X$ & $X$ & $X$ & $X$ & & \\
\hline $\begin{array}{c}\text { JB-09TP Fácies } \\
\text { Lc }\end{array}$ & $\begin{array}{l}\text { Jabuticabeira II } \\
\text { lócus } 1\end{array}$ & $X$ & $X$ & $X$ & $X$ & $X$ & $X$ & $X$ & & $X$ \\
\hline $\begin{array}{l}\text { JB-10TP Fácies } \\
\text { LA }\end{array}$ & $\begin{array}{l}\text { Jabuticabeira II } \\
\text { lócus } 1\end{array}$ & $X$ & $X$ & $X$ & $X$ & $X$ & $X$ & $X$ & & \\
\hline
\end{tabular}

5 AG: Análise granulométrica; $\mathbf{C O}_{3}$ : Quantificação de teor de carbonato; $\mathbf{M O}$ : Dosagem de teor de matéria orgânica total; MP: Análise quantitativa de minerais pesados da fração $<0,125 \mathrm{~mm}$ e $>0,062 \mathrm{~mm}$; Lupa: Análise óptica da fração grossa (maior que 0,250 mm) sob lupa binocular; Mic: Micromorfologia; $\delta^{13} \mathrm{C}$ : Análise isótópica de $\mathrm{C}$ e $\mathrm{N}$ da fração orgânica; ${ }^{14} \mathrm{C}$ : Datação carbono 14 de conchas; MEV: Microscopia eletrônica de varredura.

- Amostras de MP submetidas à oxidação por $\mathrm{H}_{2} \mathrm{O}_{2}$ e tratamento ácido com $\mathrm{HCl}$ a $10 \%$. 
Tabela 4 - continuação.

\begin{tabular}{|c|c|c|c|c|c|c|c|c|c|c|}
\hline Amostra & $\begin{array}{c}\text { Local de } \\
\text { amostragem }\end{array}$ & AG & $\mathrm{CO}_{3}{ }^{6}$ & $\mathrm{MO}^{6}$ & $\mathrm{MP}^{6}$ & Lupa $^{6}$ & $\mathrm{Mic}^{6}$ & $\delta^{13} C^{6}$ & ${ }^{14} C^{6}$ & MEV \\
\hline $\begin{array}{c}\text { JB-11TP Fácies } \\
\text { LA }\end{array}$ & $\begin{array}{l}\text { Jabuticabeira II } \\
\text { lócus } 1\end{array}$ & $X$ & $X$ & $X$ & $X$ & $X$ & $\mathrm{x}$ & $X$ & & \\
\hline $\begin{array}{c}\text { JB-12TP Fácies } \\
\text { LA }\end{array}$ & $\begin{array}{l}\text { Jabuticabeira II } \\
\text { lócus } 1\end{array}$ & $X$ & $x$ & $x$ & $X$ & X & $x$ & $X$ & & \\
\hline $\begin{array}{c}\text { JB-13TP Fácies } \\
\text { LA }\end{array}$ & $\begin{array}{c}\text { Jabuticabeira II } \\
\text { lócus } 1\end{array}$ & $X$ & $X$ & $x$ & $x$ & $x$ & $x$ & $x$ & & \\
\hline $\begin{array}{c}\text { JB-14TP Fácies } \\
\text { LA }\end{array}$ & $\begin{array}{c}\text { Jabuticabeira II } \\
\text { lócus } 1\end{array}$ & $X$ & $X$ & $X$ & $\mathrm{X}$ & X & $x$ & X & & \\
\hline $\begin{array}{c}\text { JB-15TP Fácies } \\
\text { LA }\end{array}$ & $\begin{array}{l}\text { Jabuticabeira II } \\
\text { lócus } 1\end{array}$ & $X$ & $X$ & $X$ & $x$ & $X$ & X & $x$ & & \\
\hline $\begin{array}{c}\text { JB-16TP Fácies } \\
\text { LA }\end{array}$ & $\begin{array}{l}\text { Jabuticabeira II } \\
\text { lócus } 1\end{array}$ & $X$ & $x$ & $X$ & $x$ & X & $x$ & $X$ & & \\
\hline $\begin{array}{c}\text { JB-17TP Fácies } \\
\text { LA }\end{array}$ & $\begin{array}{c}\text { Jabuticabeira II } \\
\text { lócus } 1\end{array}$ & $X$ & $X$ & $X$ & - & X & & & & X \\
\hline Interface & $\begin{array}{c}\text { Interface da } \\
\text { fácies LA com } \\
\text { a Lc do } \\
\text { sambaqui } \\
\text { Jabuticabeira II }\end{array}$ & & & & & & $X$ & & & \\
\hline JB-Poço & $\begin{array}{l}\text { Fácies areno- } \\
\text { lamosa de } \\
\text { sedimento } \\
\text { paleolagunar } \\
\text { do entorno do } \\
\text { sambaqui } \\
\text { Jabuticabeira II }\end{array}$ & & & & & & $X$ & & & \\
\hline $\begin{array}{l}\text { GS-Poço (GS- } \\
\text { Geo) }\end{array}$ & $\begin{array}{l}\text { Fácies areno- } \\
\text { lamosa de } \\
\text { sedimento } \\
\text { paleolagunar } \\
\text { do entorno do } \\
\text { sambaqui } \\
\text { Encantada III }\end{array}$ & & & & & & $x$ & & & \\
\hline JB-01- $\alpha$ (Jab Geo) & $\begin{array}{c}\text { Trincheira } \\
\text { próxima ao } \\
\text { sambaqui } \\
\text { Jabuticabeira II }\end{array}$ & $X$ & $X$ & $X$ & $X$ & & & & & \\
\hline JB-01- $\beta$ (Jab Geo) & $\begin{array}{c}\text { Trincheira } \\
\text { próxima ao } \\
\text { sambaqui } \\
\text { Jabuticabeira II }\end{array}$ & $X$ & $X$ & $X$ & - & & $X$ & $\mathrm{X}$ & & \\
\hline JB-02- $\alpha$ (Jab Geo) & $\begin{array}{c}\text { Trincheira } \\
\text { próxima ao } \\
\text { Jabuticabeira II }\end{array}$ & $X$ & $X$ & $X$ & $X$ & & & & & \\
\hline
\end{tabular}

6 AG: Análise granulométrica; $\mathbf{C O}_{3}$ : Quantificação de teor de carbonato; $\mathbf{M O}$ : Dosagem de teor de matéria orgânica total; MP: Análise quantitativa de minerais pesados da fração $<0,125 \mathrm{~mm}$ e $>0,062 \mathrm{~mm}$; Lupa: Análise óptica da fração grossa (maior que 0,250 mm) sob lupa binocular; Mic: Micromorfologia; $\delta^{13} \mathrm{C}$ : Análise isótópica de $\mathrm{C}$ e $\mathrm{N}$ da fração orgânica; ${ }^{14} \mathrm{C}$ : Datação carbono 14 de conchas; MEV: Microscopia eletrônica de varredura.

- Amostras de MP submetidas à oxidação por $\mathrm{H}_{2} \mathrm{O}_{2}$ e tratamento ácido com $\mathrm{HCl}$ a $10 \%$. 
Tabela 4 - continuação.

\begin{tabular}{|c|c|c|c|c|c|c|c|c|c|c|}
\hline Amostra & $\begin{array}{c}\text { Local de } \\
\text { amostragem }\end{array}$ & $\mathrm{AG}^{7}$ & $\mathrm{CO}_{3}{ }^{7}$ & $\mathrm{MO}^{7}$ & $\mathrm{MP}^{7}$ & Lupa $^{7}$ & $\mathrm{Mic}^{7}$ & $\delta^{13} c^{7}$ & ${ }^{14} C^{7}$ & MEV $^{7}$ \\
\hline $\begin{array}{c}\text { JB-02- } \beta \text { (Jab } \\
\text { Geo) }\end{array}$ & $\begin{array}{c}\text { Trincheira } \\
\text { próxima ao } \\
\text { Jabuticabeira II }\end{array}$ & $X$ & $X$ & $X$ & $X$ & & & $X$ & & \\
\hline $\begin{array}{c}\text { JB-03- } \alpha(\mathrm{Jab} \\
\text { Geo) }\end{array}$ & $\begin{array}{c}\text { Trincheira } \\
\text { próxima ao } \\
\text { Jabuticabeira II }\end{array}$ & $X$ & X & & $X$ & $X$ & & & $X$ & \\
\hline $\begin{array}{c}\text { JB-03- } \beta \text { (Jab } \\
\text { Geo) }\end{array}$ & $\begin{array}{c}\text { Trincheira } \\
\text { próxima ao } \\
\text { sambaqui } \\
\text { Jabuticabeira II }\end{array}$ & $X$ & $X$ & $X$ & $X$ & X & & $X$ & & \\
\hline $\begin{array}{c}\text { JB-04- } \alpha(\mathrm{Jab} \\
\text { Geo) }\end{array}$ & $\begin{array}{c}\text { Trincheira } \\
\text { próxima ao } \\
\text { sambaqui } \\
\text { Jabuticabeira II }\end{array}$ & $X$ & X & $X$ & $X$ & $X$ & & & & \\
\hline $\begin{array}{c}\text { JB-04- } \beta \text { (Jab } \\
\text { Geo) }\end{array}$ & $\begin{array}{c}\text { Trincheira } \\
\text { próxima ao } \\
\text { sambaqui } \\
\text { Jabuticabeira II }\end{array}$ & $X$ & $X$ & $X$ & $X$ & $X$ & & $X$ & & \\
\hline $\begin{array}{c}\text { JB-05- } \alpha(\mathrm{Jab} \\
\text { Geo) }\end{array}$ & $\begin{array}{c}\text { Poço } 1 \times 1 \mathrm{~m} \text { 600- } \\
700 \mathrm{~m} \text { do } \\
\text { sambaqui } \\
\text { Jabuticabeira II }\end{array}$ & $X$ & $X$ & $X$ & $X$ & & & & & \\
\hline $\begin{array}{c}\text { JB-05- } \beta \text { (Jab } \\
\text { Geo) }\end{array}$ & $\begin{array}{c}\text { Poço } 1 \times 1 \mathrm{~m} \text { 600- } \\
700 \mathrm{~m} \text { do } \\
\text { sambaqui } \\
\text { Jabuticabeira II }\end{array}$ & $X$ & $X$ & $X$ & $X$ & & & $X$ & & \\
\hline $\begin{array}{c}\text { JB-05-y (Jab } \\
\text { Geo) }\end{array}$ & $\begin{array}{l}\text { Poço } 1 \times 1 \mathrm{~m} \text { 600- } \\
700 \mathrm{~m} \text { do } \\
\text { sambaqui } \\
\text { Jabuticabeira II }\end{array}$ & $X$ & X & $X$ & $X$ & & & $X$ & & \\
\hline $\begin{array}{c}\text { CV-01a } \\
\text { (Carniça Geo) }\end{array}$ & $\begin{array}{c}\text { Trincheira } \\
\text { próxima ao } \\
\text { sambaqui } \\
\text { Carniça I } \\
\end{array}$ & $X$ & X & $X$ & $X$ & & & & & \\
\hline $\begin{array}{c}\text { CV-01ß } \\
\text { (Carniça Geo) }\end{array}$ & $\begin{array}{c}\text { Trincheira } \\
\text { próxima ao } \\
\text { sambaqui } \\
\text { Carniça I } \\
\end{array}$ & $X$ & $X$ & $X$ & $X$ & & & $X$ & $X$ & \\
\hline $\begin{array}{c}\text { CV-01y } \\
\text { (Carniça Geo) }\end{array}$ & $\begin{array}{c}\text { Trincheira } \\
\text { próxima ao } \\
\text { sambaqui } \\
\text { Carniça I } \\
\end{array}$ & $X$ & X & $X$ & $X$ & & & & & \\
\hline
\end{tabular}

7 AG: Análise granulométrica; $\mathbf{C O}_{3}$ : Quantificação de teor de carbonato; $\mathbf{M O}$ : Dosagem de teor de matéria orgânica total; MP: Análise quantitativa de minerais pesados da fração $<0,125 \mathrm{~mm}$ e $>0,062 \mathrm{~mm}$; Lupa: Análise óptica da fração grossa (maior que 0,250 mm) sob lupa binocular; Mic: Micromorfologia; $\delta^{13} \mathrm{C}$ : Análise isótópica de $\mathrm{C}$ e $\mathrm{N}$ da fração orgânica; ${ }^{14} \mathrm{C}$ : Datação carbono 14 de conchas; MEV: Microscopia eletrônica de varredura.

- Amostras de MP submetidas à oxidação por $\mathrm{H}_{2} \mathrm{O}_{2}$ e tratamento ácido com $\mathrm{HCl}$ a $10 \%$. 
Tabela 4 - continuação.

\begin{tabular}{|c|c|c|c|c|c|c|c|c|c|c|}
\hline Amostra & $\begin{array}{c}\text { Local de } \\
\text { amostragem }\end{array}$ & $A G^{8}$ & $\mathrm{CO}_{3}{ }^{8}$ & $\mathrm{MO}^{8}$ & $M P^{8}$ & Lupa $^{8}$ & $\mathrm{Mic}^{8}$ & $\delta^{13} C^{8}$ & ${ }^{14} C^{8}$ & MEV $^{8}$ \\
\hline $\begin{array}{c}\text { CV-01ठ } \\
\text { (Carniça Geo) }\end{array}$ & $\begin{array}{c}\text { Trincheira } \\
\text { próxima ao } \\
\text { sambaqui } \\
\text { Carniça I } \\
\end{array}$ & $X$ & $X$ & $X$ & $X$ & & & $X$ & & \\
\hline $\begin{array}{l}\text { CV-Areia } \\
\text { (Carniça III } \\
\text { areia) }\end{array}$ & $\begin{array}{l}\text { Porção quartzo- } \\
\text { arenosa do } \\
\text { sambaqui } \\
\text { Carniça III }\end{array}$ & $X$ & $X$ & $X$ & • & $X$ & & & & \\
\hline $\begin{array}{c}\text { CV-TP } \\
\text { (Carniça III } \\
\text { TP) }\end{array}$ & $\begin{array}{c}\text { "Terra preta" do } \\
\text { sambaqui } \\
\text { Carniça III } \\
\end{array}$ & $X$ & $X$ & $X$ & • & $X$ & & $X$ & & \\
\hline GS-01 & $\begin{array}{c}\text { Vala próxima a } \\
\text { tanque de } \\
\text { carcinicultura } \\
\text { nas } \\
\text { proximidades do } \\
\text { sambaqui } \\
\text { Encantada III }\end{array}$ & $X$ & & $X$ & $x$ & $X$ & X & $X$ & & \\
\hline GS-Areia & $\begin{array}{c}\text { Camada } \\
\text { arenosa do } \\
\text { sambaqui } \\
\text { Encantada III, } \\
\text { trincheira } 3\end{array}$ & $x$ & & & $X$ & X & & & & \\
\hline GS-TP & $\begin{array}{c}\text { "Terra preta" do } \\
\text { topo do } \\
\text { sambaqui } \\
\text { Encantada III } \\
\text { trincheira } 3 \\
\end{array}$ & $X$ & & & $X$ & $X$ & & $X$ & & \\
\hline $\begin{array}{l}\text { GS03- } \alpha \\
\text { (GS Geo) }\end{array}$ & $\begin{array}{c}\text { Trincheira } \\
\text { próxima ao } \\
\text { sambaqui } \\
\text { Encantada III }\end{array}$ & $X$ & & & & & & & & \\
\hline $\begin{array}{l}\text { GS03- } \beta \text { (GS } \\
\text { Geo) }\end{array}$ & $\begin{array}{c}\text { Trincheira } \\
\text { próxima ao } \\
\text { sambaqui } \\
\text { Encantada III }\end{array}$ & $X$ & & & & & & & & \\
\hline $\begin{array}{c}\text { GS03-y (GS } \\
\text { Geo) }\end{array}$ & $\begin{array}{c}\text { Trincheira } \\
\text { próxima ao } \\
\text { sambaqui } \\
\text { Encantada III }\end{array}$ & $X$ & & & & & & & & \\
\hline $\begin{array}{c}\text { GS03-ס (GS } \\
\text { Geo) }\end{array}$ & $\begin{array}{c}\text { Trincheira } \\
\text { próxima ao } \\
\text { sambaqui } \\
\text { Encantada III }\end{array}$ & $X$ & & & & & & & & \\
\hline
\end{tabular}

8 AG: Análise granulométrica; $\mathbf{C O}_{3}$ : Quantificação de teor de carbonato; $\mathbf{M O}$ : Dosagem de teor de matéria orgânica total; MP: Análise quantitativa de minerais pesados da fração $<0,125 \mathrm{~mm}$ e $>0,062 \mathrm{~mm}$; Lupa: Análise óptica da fração grossa (maior que 0,250 mm) sob lupa binocular; Mic: Micromorfologia; $\delta^{13} \mathrm{C}$ : Análise isótópica de $\mathrm{C}$ e $\mathrm{N}$ da fração orgânica; ${ }^{14} \mathrm{C}$ : Datação carbono 14 de conchas; MEV: Microscopia eletrônica de varredura.

- Amostras de MP submetidas à oxidação por $\mathrm{H}_{2} \mathrm{O}_{2}$ e tratamento ácido com $\mathrm{HCl}$ a $10 \%$. 


\subsubsection{Determinação do teor de matéria orgânica total e carbonatos}

A determinação do teor de matéria orgânica total nos sedimentos coletados foi realizada com o intuito de comparar os sambaquis (capa e lâminas de "terra preta") e terrenos paleolagunares adjacentes, de aspecto similar, no âmbito do estudo de proveniência dos sedimentos dos sítios estudados.

A determinação da diferença de massa (em \%) após ataque com $\mathrm{HCl}$ permite a quantificação de bioclastos ou vestígios de vida susceptíveis a degradação por esse ácido, isto é, conchas (fase carbonática) e/ou ossos (fase fosfática). Nos sambaquis estudados, ambas as fases são bem representadas. Já nos sedimentos geogênicos, o resultado desta análise corresponde basicamente ao teor de carbonatos.

Para a determinação do teor de matéria orgânica, separou-se uma alíquota da ordem de $50 \mathrm{~g}$ de sedimento, tal qual coletado. Esta alíquota foi seca em estufa a $75-80^{\circ} \mathrm{C}$ por aproximadamente 16 horas, pesada com precisão de 0,001g e submetida à oxidação da matéria orgânica, com quantidade de peróxido de hidrogênio $\left(\mathrm{H}_{2} \mathrm{O}_{2}\right)$ a 15 volumes suficiente para fazer desaparecer os sinais de reação (formação de espuma).

O carvão, encontrado principalmente em sedimentos oriundos dos sítios arqueológicos, também se mostrou passível de oxidação parcial, o que está ligado ao fato de ele não se achar totalmente na forma elementar (C). Foram observados, durante o ataque com $\mathrm{H}_{2} \mathrm{O}_{2}$, restos de carvão (elementar) não consumidos pela oxidação, e que, por serem muito leves, migraram para a superfície da solução. Este sobrenadante foi sifonado para descarte, restando apenas a fração não orgânica (ou não carbonosa).

Após o processo de oxidação, lavagem e secagem, o mesmo material foi novamente pesado e submetido ao ataque com ácido clorídrico $(\mathrm{HCl}) 10 \%$, até cessar a reação. O resíduo insolúvel foi lavado, seco em estufa a $100^{\circ} \mathrm{C}$ e novamente pesado. A diferença entre o peso seco inicial e o peso seco final de cada etapa (oxidação e ataque ácido) permitiu determinar respectivamente as porcentagens em peso de matéria orgânica total e de carbonatos mais fosfatos.

O material tratado conforme descrito acima foi submetido à análise granulométrica descrita no item 4.2.2.

As determinações do teor de matéria orgânica total e de carbonatos mais fosfatos foram realizadas no Laboratório de Materiais de Construção Civil do IPT. 


\subsubsection{Análise granulométrica}

A análise granulométrica foi realizada com o objetivo de verificar a possível correlação entre o sedimento arenoso dos sambaquis Jabuticabeira II, Carniça III e Encantada III e o sedimento arenoso dos sistemas deposicionais do entorno.

A granulometria, para cada amostra, foi executada conforme o protocolo que se segue.

O material seco previamente em estufa foi pesado, destorroado e submetido então à análise das classes de $1 \Phi($ phi) de silte e argila, pelíchica da pipetag em. Para tanto, foram-Ihe inicialmente adicionados $1 \mathrm{~g}$ de hexametafosfato de sódio (defloculante) e $400 \mathrm{ml}$ de água deionizada ou destilada. A dispersão assim obtida foi agitada por 10 min em um misturador giratório de hélice de metal, a $600 \mathrm{rpm}$. Colocou-se o material disperso em proveta de $1000 \mathrm{ml}$. A dispersão em água obtida de cada operação de destorroamento foi sucessivamente acrescentada à suspensão na proveta, até que a água de destorroamento ficasse completamente límpida. O volume final de suspensão na proveta foi completado em $1000 \mathrm{ml}$ antes do início da pipetagem.

A suspensão foi pipetada com seringa de vidro acoplada a pipeta volumétrica, em cinco alíquotas sucessivas de $20 \mathrm{ml}$, segundo os tempos de pipetagem obtidos pela fórmula da lei de Stokes $^{9}(1)$, calculados para valores de $r$ (raio da partícula) limítrofes da classe argila e das quatro classes de silte, na escala de Wentworth.

$$
\begin{aligned}
\mathrm{t}_{\mathrm{n}}=\mathrm{h}_{\mathrm{n}} \times \eta \times & 9 / 2 \times \mathrm{g} \times\left(\mathrm{d}_{1}-\mathrm{d}_{2}\right) \times \mathrm{r}_{\mathrm{n}}^{2} \\
\mathrm{t}_{\mathrm{n}} & =\text { tempo de pipetagem para a fração }(\mathrm{s}) ; \\
\mathrm{h}_{\mathrm{n}} & =\text { profundidade de pipetagem }(20 \text { ou } 10 \mathrm{~cm}) ; \\
\eta & =\text { viscosidade da água }(\mathrm{g} / \mathrm{cm} . \mathrm{s}) ; \\
\mathrm{g} & =\text { aceleração da gravidade }\left(978,6 \mathrm{~cm} / \mathrm{s}^{2}\right) ; \\
\mathrm{d} 1 & =\text { densidade média das partículas }\left(2,65 \mathrm{~g} / \mathrm{cm}^{3}\right) ; \\
\mathrm{d} 2 & =\text { densidade da água conforme tabela abaixo; }
\end{aligned}
$$$$
r_{n}=\text { raio da maior partícula na fração }(0,0031,0,0016,0,0008,0,0004 \text { e 0,002 cm). }
$$

${ }^{9}$ A lei de Stokes refere-se à queda de objetos esféricos em movimento retilíneo uniforme em fluido de viscosidade conhecida, em regime laminar (baixo números de Reynolds), sob condição de força de resistência viscosa equilibrada com força peso. 
O material pipetado foi despejado em placas de Petri e submetido a secagem em estufa a $40-55^{\circ} \mathrm{C}$. Após a secagem, os pesos contidos nas cinco placas foram determinados em balança analítica calibrada com resolução de 0,001g.

Após a pipetagem, submeteu-se a suspensão a peneiramento para a retirada de materiais finos $(<0,062 \mathrm{~mm}$ ou maior que $4 \Phi)$. O material retido foi seco em estufa, pesado com precisão de $0,01 \mathrm{~g}$ e submetido a peneiramento a seco, em conjunto de 13 peneiras em intervalos de 0,5 $\Phi$, entre $4,0 \mathrm{~mm}$ e $0,062 \mathrm{~mm}$, mais recipiente de fundo. Os pesos dos materiais retidos foram determinados para cada peneira.

Os resultados de pesagem das frações peneiradas e pipetadas foram tabulados no software Momento 4.1 (Giannini \& Nascimento, 2007), que calcula as proporções em massa das classes de 1,0 Ф e os pâmetros estatísticos de distribuição granulométrica segundo Pearson, com e sem cômputo da fração pelítica.

De forma a incrementar os resultados relativos à proveniência, obtidos neste trabalho, utilizaram-se os resultados granulométricos obtidos por Giannini (1993) e Tanaka (2007) para as localidades de Jabuticabeira (Eólicos Jab Giannini) e Campos Verdes, respectivamente.

A granulometria foi realizada no Laboratório de Materiais de Construção Civil (LMCC) do Instituto de Pesquisas Tecnológicas do Estado de São Paulo (IPT).

\subsubsection{Mineralogia de pesados}

A quantificação de minerais pesados opacos não magnéticos e transparentes é uma técnica consagrada na determinação da proveniência de sedimentos. $\mathrm{Na}$ presente Dissertação, utilizou-se esta técnica com a finalidade de acrescentar parâmetros no cruzamento de dados para determinação da proveniência dos sedimentos dos sambaquis estudados. Além da proveniência, esta análise apresenta potencial na caracterização de processos de dissolução pós-deposicional (em sambaquis, por exemplo), quando da constatação de alteração textural ou redução quantitativa de minerais mais instáveis, em relação a textura ou composição mineralógica original de área fonte ou área de controle (sedimentos geogênicos extra-sítio ou sedimentos de porções menos permeáveis do sambaqui, como concreções).

De forma a tornar possível a determinação da quantidade e tipologia de minerais pesados nos sedimentos estudados, a fração areia muito fina (retida na peneira $0,062 \mathrm{~mm}$ e passante na $0,125 \mathrm{~mm}$ ), situada uma classe abaixo da moda granulométrica para grande parte das amostras, foi submetida a decantação em líquido denso (bromofórmio: densidade $2,8 \mathrm{~g} / \mathrm{cm}^{3}$ a $20^{\circ} \mathrm{C}$ ). Em seguida, com um imã de mão revestido por invólucro de papel, foram 
retiradas as fases minerais magnéticas da porção pesada. As lâminas de grãos pesados não magnéticos foram montadas utilizando bálsamo do Canadá como meio de imersão, cujo índice de refração, determinado pelo fabricante, é 1,56.

Algumas amostras de sedimentos para a separação de pesados foram submetidas a tratamento químico com $\mathrm{H}_{2} \mathrm{O}_{2}$ e $\mathrm{HCl} 10 \%$ (vide Tabela 4 - listagem de amostras), o que pode ter afetado as quantidades de ossos e de minerais terrígenos sensíveis à dissolução ácida, como seguramente apatita (o restante dos minerais identificados é supostamente pouco ou nada afetado por tratamento ácido). A identificação e contagem de minerais pesados foram feitas sob microscópio óptico, de acordo com o método de contagem de área ou ribbon method descrito em Galehouse (1971). Este método fornece resultado expresso em \%, obtida a partir do número de grãos minerais.

A separação e montagem de lâmina de minerais pesados foram realizadas no Laboratório de Materiais de Construção Civil do Instituto de Pesquisas Tecnológicas do Estado de São Paulo e no Laboratório de Sedimentologia do Instituto de Geociências da Universidade de São Paulo.

A identificação e contagem de minerais pesados e a coleta de imagens digitais foram realizados em microscópio Carl-Zeiss Axioplan 2 com analisador Leica Qwin, locado no Laboratório de Petrografia Sedimentar (LabPetro) do Instituto de Geociências (IGc) da Universidade de São Paulo (USP).

O cálculo dos índices de maturidade química utilizando os minerais ultraestáveis zircão, turmalina e rutilo (iZTR) foi feito de acordo com a proposta original de Hubert (1962). Para a soma de minerais semi-estáveis (ou metaestáveis) e instáveis, foi utilizado o critério classificatório proposto por Hubert (1971), o qual lista apatita, monazita, estaurolita, o grupo dos polimorfos de $\mathrm{Al}_{2} \mathrm{SiO}_{5}$, e o grupo do epídoto na classe dos minerais metaestáveis, e hornblenda e augita na classe dos instáveis. Foram adicionados aos instáveis os minerais do grupo dos anfibólios e piroxênios encontrados além da hornblenda e augita, e à classe dos metaestáveis, a granada. Os minerais alterados cuja identificação não foi possível receberam a nomenclatura "alterita".

Os dados mineralógicos foram graficamente analisados, em relação a sua variação por grupo de amostra, utilizando-se diagramas em caixa ou boxplot (Figura 29).

\subsubsection{Análise da fração grossa sob microscópio estereoscópico}

O objetivo do exame das frações grossas sob lupa binocular foi a caracterização e quantificação por estimativa visual de tipos texturais-mineralógicos de grãos, como 
refinamento para a análise das fácies presentes nos sambaquis e nos sedimentos geogênicos (poços de controle). Esta caracterização permite o reconhecimento de fases granulares grossas (acima de 0,25mm) de modo pormenorizado, o que não é possível durante a etapa de campo.

As amostras coletadas foram secas em estufa a $60-80^{\circ} \mathrm{C}$ e submetidas a peneiramento, tendo em vista o fracionamento do material retido nas malhas 4,0 mm (seixo), 2,0 mm (grânulo), 1,0 mm (areia muito grossa), 0,50 mm (areia grossa) e 0,25 $\mathrm{mm}$ (areia média).

O estudo do material de cada fração retida à lupa envolveu primeiramente o reconhecimento das fases presentes, por critérios ópticos de suposto significado textural e composicional. Feito este reconhecimento, montou-se um formulário contendo as fases mais comuns, preenchido com a porcentagem em área de cada fase identificada, com auxílio do diagrama de estimativa visual da Figura 27.
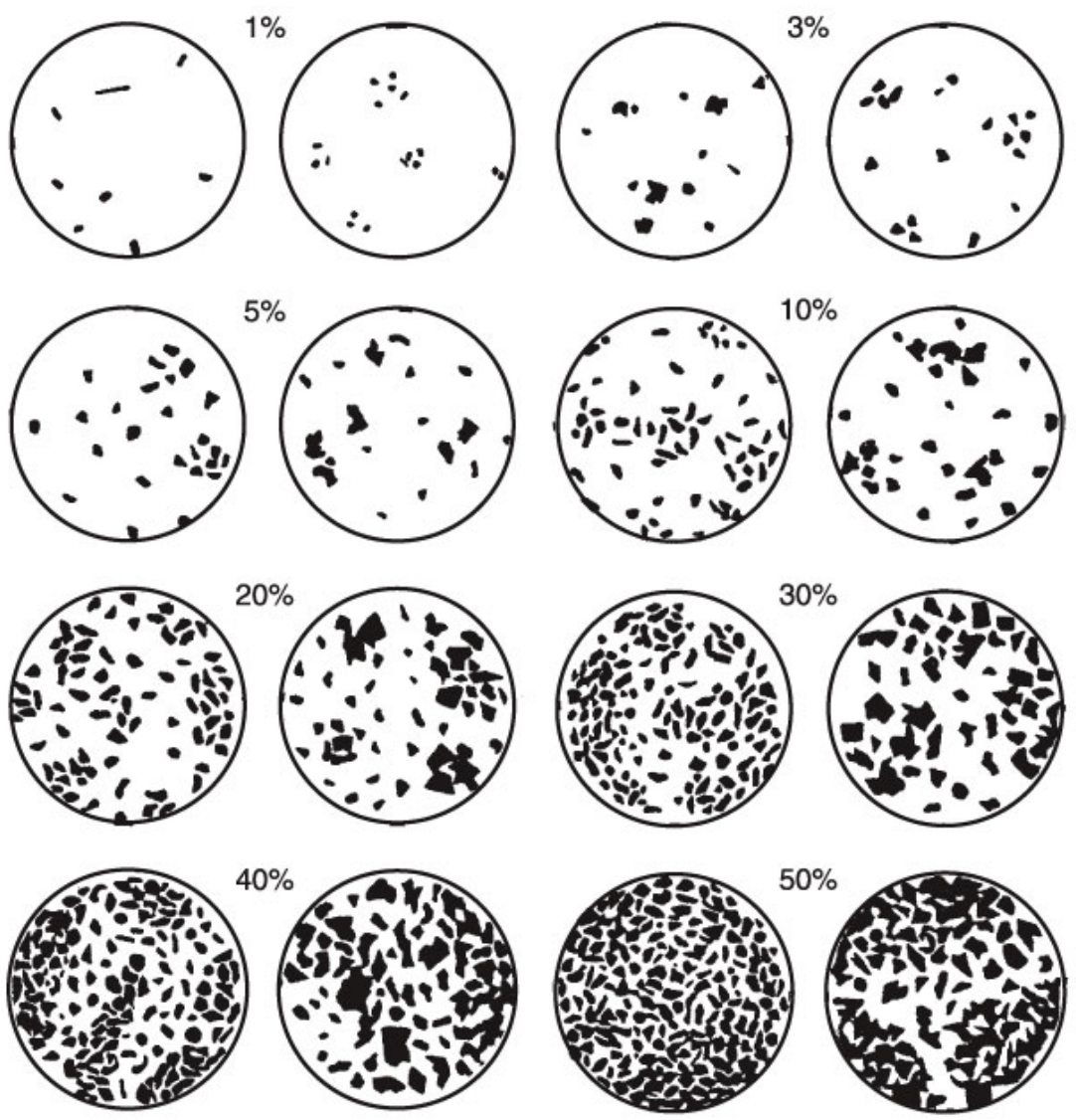

Figura 27 - Diagrama para semiquantificação por estimativa visual. Modificado de Terry e Chilingar (1955) apud May et al. (2002).

As porcentagens das fases foram submetidas a cálculo de média ponderada pela porcentagem em massa de cada fração. Os resultados apresentados no texto, bem como em tabela no Anexo, são relativos a esta média ponderada. 
A identificação e semiquantificação de fases e a coleta de imagens digitais foram realizados em lupa binocular Zeiss Stemi SV.11, com câmera digital CCD Sony e analisador Leica Qwin, locados no Laboratório de Petrografia Sedimentar (LabPetro) do Instituto de Geociências (IGc) da Universidade de São Paulo (USP).

\subsubsection{Micromorfologia}

A micromorfologia de sedimentos do sambaqui Jabuticabeira II foi conduzida com o intuito de refinar a descrição faciológica da "terra preta", uma vez que a descrição de fácies em campo não permitiu notar diferenças claras entre as várias recorrências desta fácies, seja na forma de lâminas seja como camada de topo.

A análise micromorfológica foi realizada em 19 seções delgadas (3qum de espessura por 7,5 x 5cm de área) de sedimento de lâminas "funerárias" e "terra preta" previamente endurecido, via impregnação com resina, conforme o protocolo descrito a seguir.

O testemunho orientado (com topo e base indicados) obtido em campo (Figura 20 a Figura 23) foi colocado em estufa durante seis horas, a $60^{\circ} \mathrm{C}$. Após a secagem da amostra, preparou-se a mistura para impregnação juntando-se $100 \mathrm{~g}$ de resina epóxi (EP 1204), $10 \mathrm{~g}$ de endurecedor (EP 1604), 50 a $75 \mathrm{~g}$ de álcool etílico e corante azul Oracet. Colocou-se o recipiente em dessecador ligado a uma bomba de vácuo para que a amostra pudesse absorver apropriadamente a resina. Adicionou-se lentamente a mistura de resina à amostra, na lateral do recipiente metálico contendo o testemunho. Após a impregnação, a amostra foi levada para a estufa a $60-75^{\circ} \mathrm{C}$ por aproximadamente 16 horas, até o endurecimento.

Depois de endurecida, a amostra foi cortada com auxílio de serra de disco diamantado até obtenção de uma placa de aproximadamente $1,5 \mathrm{~cm}$ de espessura, com as dimensões aproximadas da lâmina de vidro, onde foi colada com resina epóxi na proporção de $3 \mathrm{~g}$ de resina (EP 1501) para 1g de catalisador (EP 1601). Após a secagem da cola (por 16 horas, a temperatura ambiente), a amostra foi desbastada na serra diamantada e manualmente, com pó abrasivo (carbeto de silício), até a obtenção da espessura padrão de aproximadamente $30 \mu \mathrm{m}$.

Os critérios descritivos utilizados nesta dissertação seguem Stoops (2003) e Giannini (2006). A adoção de uma forma de descrição composta de duas propostas distintas, e de disciplinas diferentes, baseou-se na conclusão da discussão metodológica, apresentada no item 3.4.4, segundo a qual materiais de origem mista (supostamente pedogênica e sedimentar) são melhor descritos pela combinação de critérios e enfoques da micromorfologia e da petrografia sedimentar. 
Para a estimativa visual da porcentagem em área dos componentes presentes nas seções delgadas, utilizou-se o diagrama modificado de Terry e Chilingar (1955) apud May et al. (2002), Figura 27.

\section{Medidas de empacotamento}

As medidas de empacotamento realizadas tratam da freqüência percentual de contatos intergranulares em relação ao total de grãos que cruzam o retículo do microscópio, no exame de seção delgada sob aumento de 50x (Figura 28). Esta medida fornece um valor de proximidade entre os grãos, que pode ser entendido como índice de empacotamento. A avaliação do empacotamento é útil para se ter um juízo do grau de compactação sofrida pelo sedimento. A comparação de taxas de compactação inferidas a partir do empacotamento de materiais similares pode ser utilizada na identificação de superfícies de pisoteamento ou ajudar na determinação de processos de lixiviação pós-deposicional.

O índice de empacotamento de Kahn (1956) ( $\mathrm{P}_{\mathrm{k}}$ ou Pp, de packing proximity), adotado nesta Dissertação, pode ser resumido na fórmula 2, onde q é o número de contatos grãogrão e $\mathbf{n}$ é o número total de grãos.

$$
\mathrm{iP}_{\mathrm{K}}=(\mathrm{q} / \mathrm{n}) \times 100 \quad(0 \leq \mathrm{q} \leq \mathrm{n})
$$

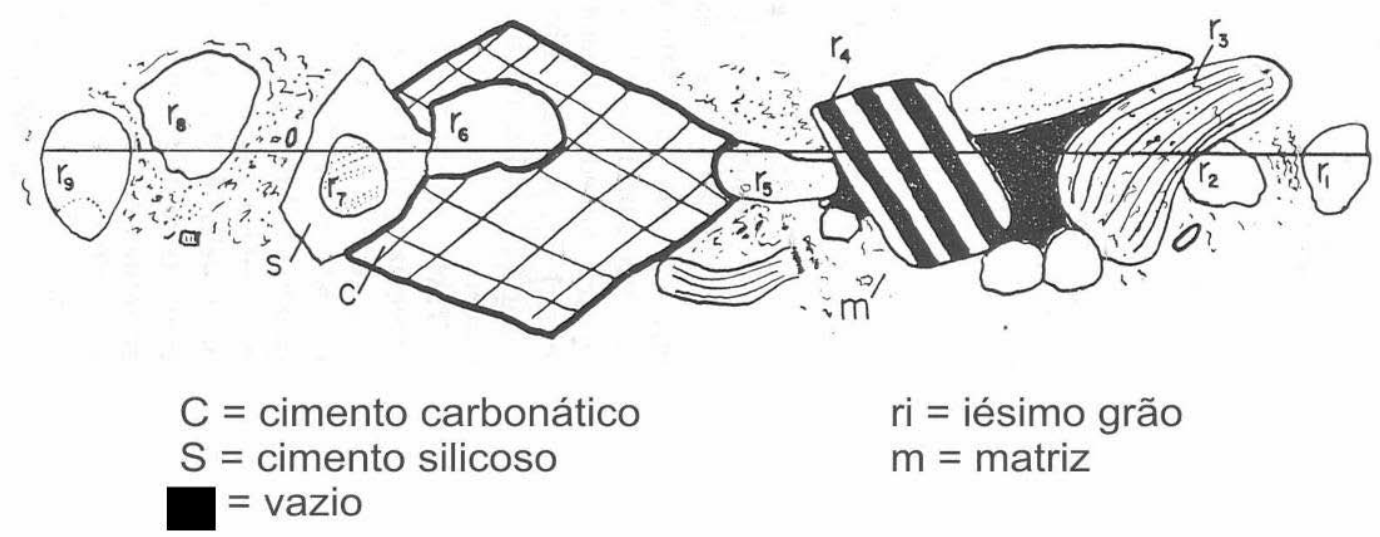

Figura 28 - Esquema de contagem de número de grãos e número de contatos grão-grão que cruzam o retículo (linha horizontal). Nesta figura, o retículo corta nove grãos e apenas um contato grão-grão; portanto, a proximidade de empacotamento é 1/9 x $100=11,11 \%$, de acordo com a fórmula 2. Modificado de Kahn (1956).

Duas medidas de índice de empacotamento foram obtidas por seção delgada estudada, uma na vertical (transversal à superposição das camadas) e outra na horizontal. Optou-se por fazer medições ao longo de cinco linhas horizontais e cinco linhas verticais por seção, por 
considerar-se que esta distribuição fornece boa cobertura em área, representativa de toda a lâmina. Os resultados percentuais finais apresentados são função do total de contatos grãogrão dividido pelo total de grãos das cinco medidas, em cada uma das duas direções.

\section{Medidas de porosidade}

As medidas de porosidade auxiliam na compreensão dos processos de compactação mecânica (pisoteamento, adensamento diagenético etc) bem como de processos de dissolução, infiltração e compactação pós-deposicional. Aliadas aos dados de proximidade de empacotamento, fornecem subsídios para a interpretação do significado estratigráfico da fácies analisada, por exemplo, como superfície delimitante (sujeita a exposição e/ou pisoteamento).

A determinação da porosidade foi feita nas seções delgadas das amostras JB-01 TP a JB-16 TP, com utilização de rotina de análise de imagens criada através do software Leica QWin. Seguiu-se procedimento modificado de Gesicki (2007), concebido originalmente para medição de porosidade em arenitos. Este procedimento baseia-se na aquisição de imagens a partir do microscópio, com aumento nominal de 50x e resolução de 764 x 574 pixels, o que representa um campo de visão microscópica (CMV) de $3,81 \mathrm{~mm}^{2}$. Na rotina utilizada, cada imagem captada é processada no software analisador a fim de se reconhecer e discriminar o matiz (hue) dos poros, tingidos de azul. Após o reconhecimento dos poros por parte do software, a imagem sofre edição para corrigir imprecisões de reconhecimento do matiz, de modo a discriminar somente os poros da amostra. Reconhecido o matiz, a partir da imagem captada e editada, o software detecta a porcentagem de pixels da imagem correspondente aos poros (Img poros), em relação à imagem total (img total), ou seja, Img total - Img poros = $\%$ de poros em área.

O software do analisador foi programado para processar a imagem como um todo, ou seja, como um único campo e, com campos múltiplos (28 campos), resultando em duas determinações de porcentagem de poros por lâmina.

Foram captadas e processadas cinco imagens, no formato TIFF, por seção delgada, distribuídas de forma homogênea e obedecendo a repetibilidade do padrão de distribuição dos campos.

O equipamento utilizado na etapa de microscopia óptica foi um microscópio petrográfico Carl-Zeiss Axiolplan 2, com câmera Sony 3CCD acoplada. A câmera está ligada a um microcomputador contendo o software Leica Qwin 550, de análise de imagens. Os equipamentos estão locados no LabPetro - IGc - USP. 
A rotina do software Qwin utilizada envolveu modificações na resolução e quantidade de quadros na rotina original de Gesicki (2007) ("porosidade-library-color-v-3.1"), tendo sido salva sob a denominação de "teste porosidade 3".

\subsubsection{Microscopia eletrônica de varredura}

O Microscópio Eletrônico de Varredura (MEV) pode ser definido como um equipamento de microanálise morfológica não destrutivo capaz de produzir imagens com grandes aumentos (com o detector de elétrons secundários), além de indicar a diferença de número atômico médio (através do detector de elétrons retroespalhados). Ele é conjugado a um detector de raios-X, o espectrômetro de energia dispersiva (EDS), equipamento de microanálise química, com capacidade para realizar análises qualitativas e semiquantitativas (de elementos mais pesados que o boro).

A microscopia eletrônica de varredura foi utilizada em dois tipos de amostras distintos: amostras "tal qual" (conforme coletada em campo, sem beneficiamento) e seções delgadas utilizadas para micromorfologia. As amostras "tal qual" foram obtidas por meio de seleção dos fragmentos analisados sob lupa binocular e de amostras brutas, com o objetivo de verificar os aspectos morfológicos de algumas fases identificadas durante análise sob lupa; já as seções delgadas foram selecionadas de acordo com a análise óptica prévia de cada uma, com o objetivo de caracterizar textura e composição da micromassa, uma vez que a capacidade de aumento do microscópio óptico não permite a investigação apurada destes parâmetros.

Os dois tipos de amostras receberam tratamentos distintos antes de serem analisados ao MEV. As amostras "tal qual" receberam recobrimento com ouro, por ionização, para possibilitar melhor desempenho com o detector de elétrons secundários, e permitir assim aumentos de grande magnitude e imagens de alta definição, imprescindíveis em estudos morfológicos. Já as amostras em seção delgada receberam recobrimento de carbono, por evaporação, o que possibilita melhor desempenho na utilização do detector de elétrons retroespalhados e do EDS, necessário no estudo de mapeamento dos elementos químicos de interesse.

\section{Investigação morfológica}

As condições de trabalho adotadas no MEV durante a investigação morfológica podem ser identificadas nas respectivas imagens pelos símbolos WD (distância de trabalho), referente ao ajuste do foco, e EHT (diferença de potencial), relativo ao ajuste da corrente. Após o acerto do brilho e do contraste, reduz-se o aumento para procurar a área desejada à 
análise. Uma vez escolhida e aumentada a área de interesse, o brilho e o contraste são reacertados; a velocidade de varredura é diminuída e a imagem é congelada para a possível gravação digital em disco (CD-R).

\section{Mapeamento elementar}

Através deste tipo de análise, em uma determinada área da amostra, é obtido o rastreamento de elementos químicos, sendo identificados através de cores pré-determinadas em relação ao tipo de elemento químico procurado. Após a obtenção de imagens de elétrons retroespalhados (QBSD), ajusta-se o brilho do fundo de tela da impressão e aguarda-se a análise por aproximadamente duas horas e meia, com a finalidade de adensar a concentração de cores. Quando esta concentração estiver completa, a imagem é congelada e salva. Depois de observado o mapeamento, é importante a realização de análise qualitativa e semi-quantitativa nos pontos que apresentarem interesse, por exemplo os de maior concentração de cada elemento mapeado.

Dois tipos de mapeamento elementar podem ser realizados: por intensidade e por presença. O mapeamento por intensidade fornece um resultado onde as áreas mais coloridas pelos pontículos possuem maior intensidade (em massa não quantificável) do elemento químico escolhido; ou seja, onde os pontículos apresentam-se em maior quantidade, o elemento é mais abundante. Já o mapeamento por presença não distingue quantidade, mas apenas a presença do elemento químico escolhido. Ainda assim, neste tipo de mapeamento, é possível observar concentrações de pontículos, representativas de maior densidade na presença do elemento em questão.

Ao observar uma imagem obtida por mapeamento elementar, deve-se atentar para o efeito ruído, que se constitui de pontículos espalhados quase uniformemente pela imagem. Estes pontículos espalhados não indicam nem a presença nem a intensidade do elemento químico escolhido, devendo ser ignorados na interpretação.

\subsubsection{Isotopia de carbono e nitrogênio: $\delta^{13} \mathrm{C}$ e $\delta^{15} \mathrm{~N}$}

$\mathrm{A}$ análise dos isótopos estáveis de carbono $\left({ }^{13} \mathrm{C}\right.$ e $\left.{ }^{12} \mathrm{C}\right)$, aliada à determinação do carbono orgânico total (TOC) e de isótopos estáveis do nitrogênio $\left({ }^{15} \mathrm{~N}\right.$ e $\left.{ }^{14} \mathrm{~N}\right)$, constitui ferramenta importante na indicação da origem da matéria orgânica em sedimentos (Lamb et al., 2006). Foi com este intuito que as análises isotópicas de $C$ e $\mathrm{N}$ foram realizadas nos sedimentos com matéria orgânica (fácies "funerárias" e "terra preta") dos sambaquis 
Jabuticabeira II, Carniça III e Encantada III e dos poços vizinhos destes sambaquis (Tabela 4 - listagem de amostras).

A análise de isótopos estáveis foi realizada por combustão via seca. Neste processo, $100 \mathrm{mg}$ de amostra foram inseridos em tubo de ensaio juntamente com óxido de cobre (CuO) e óxido de cálcio ( $\mathrm{CaO}$ ), e em seguida submetidos a vácuo. A amostra foi queimada à temperatura de $550^{\circ} \mathrm{C}$, com liberação de gás carbônico $\left(\mathrm{CO}_{2}\right)$, água $\left(\mathrm{H}_{2} \mathrm{O}\right)$ e nitrogênio $\left(\mathrm{N}_{2}\right)$. O nitrogênio e o carbono foram medidos em suas razões isotópicas a partir dos gases $\mathrm{N}_{2}$ e $\mathrm{CO}_{2}$ liberados pelo processo de calcinação.

Os valores limítrofes de $\delta^{13} \mathrm{C}$ e razão $\mathrm{C} / \mathrm{N}$ para cada tipo de matéria orgânica, utilizados na construção de gráficos de interpretação de resultados, foram obtidos de Lamb et al. (2006); e os valores limítrofes de $\delta^{15} \mathrm{~N}$ foram retirados de White (2001).

As análises de isótopos estáveis foram realizadas no Laboratório de Isótopos Estáveis do Centro de Energia Nuclear na Agricultura (CENA) da USP, campus Piracicaba.

\subsubsection{Isotopia de carbono: ${ }^{14} \mathrm{C}$}

Datação por carbono 14 foi realizada em bioclastos ou vestígios de vida de Anomalocardia brasiliana (conchas inteiras) pertencentes a fácies mapeadas por Giannini (1993) como paleolagunares, situadas em área próxima ao sambaqui Jabuticabeira II (concentrado de conchas da amostra JB-03- $\alpha$ ) e junto ao sambaqui Carrụa I (concentrado

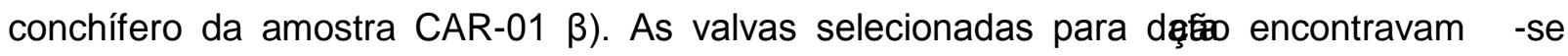
inteiras, sem indícios de predação ou retrabalhamento por transporte sedimentar (evidenciado por perda do lustro e das margens). Esta seleção permite inferir que as idades obtidas para estas conchas sejam extrapoladas como a idade deposicional da camada sedimentar em que foram encontradas. As datações serviram de parâmetro cronológico (idade máxima, considerando a possibilidade, ainda que remota, de as conchas serem retrabalhadas) da fácies lagunar bioclástica, a fim de situar esta fácies geogênica no contexto formativo dos sambaquis deste estudo.

O método de datação com o nuclídeo ${ }^{14} \mathrm{C}$ foi colocado em prática na década de 50 , e desde então é a principal ferramenta para a determinação cronológica de eventos com até aproximadamente 50.000 anos AP (antes do presente), utilizada em arqueologia, geologia, paleobotânica, paleogeografia e paleoclimatologia.

Esse método baseia-se na produção contínua do carbono radioativo $\left({ }^{14} \mathrm{C}\right)$ na alta atmosfera, por intermédio da ação de nêutrons da radiação cósmica sobre átomos de nitrogênio $\left({ }^{14} \mathrm{~N}\right)$. O ${ }^{14} \mathrm{C}$ reage com o oxigênio formando ${ }^{14} \mathrm{CO}_{2}$ e entra no ciclo global do 
carbono. Os vegetais e demais organismos fotossintetizantes assimilam esse ${ }^{14} \mathrm{CO}_{2}$, e seguindo o rito da cadeia alimentar, são ingeridos por animais ( $2^{\circ}$ nível trófico). Assim, todos os organismos vivos reabastecem-se continuamente de ${ }^{14} \mathrm{C}$ durante a vida. Com a morte de plantas e animais, a entrada de ${ }^{14} \mathrm{C}$ é cessada. $\mathrm{O}{ }^{14} \mathrm{C}$ decai com uma meia-vida de 5.730 anos para ${ }^{14} \mathrm{~N}$, de modo que o tempo de morte do indivíduo pode ser estimado através do ${ }^{14} \mathrm{C}$ residual contido em uma amostra. Quanto maior a concentração de ${ }^{14} \mathrm{C}$ em uma amostra, mais jovem ela é.

Considera-se como limite teórico do método o período de dez meias-vidas do ${ }^{14} \mathrm{C}$, ou seja, depois de 57.300 anos todo o ${ }^{14} \mathrm{C}$ cede lugar ao ${ }^{14} \mathrm{~N}$. Por convenção internacional, utiliza-se o valor da meia-vida de 5.568 anos, estabelecido na década de 1950.

No caso deste trabalho, a atividade do ${ }^{14} \mathrm{C}$ das amostras (concentrados de conchas inteiras) foi determinada utilizando-se espectrômetros de cintilação líquida do Laboratório de Carbono 14 do CENA-USP.

Para a calibração das idades, utilizou-se o software Calib 5.0 (Stuiver \& Reimer, 1993), disponível online no sítio http://calib.qub.ac.uk/calib/fractionation.html (acessado em 17.11.2008). O protocolo utilizado, SHCAL04, segue McCormac et al. (2004).

\subsubsection{Tratamento estatístico}

Os resultados de granulometria foram analisados em relação à estatística descritiva e multivariada nos softwares Minitab 15 e Microsoft Excel 2003.

Para representar a distribuição de freqüências de cada tipo de dado, utilizou-se o diagrama em caixa (boxplot), ferramenta gráfica de estatística descritiva que fornece um resumo gráfico desta distribuição. Esse tipo de diagrama permite observar a extensão das caudas da distribuição (através dos bigodes e dos outliers) e a tendência central (através da mediana e dos quartis), conforme esquema representado na Figura 29. 


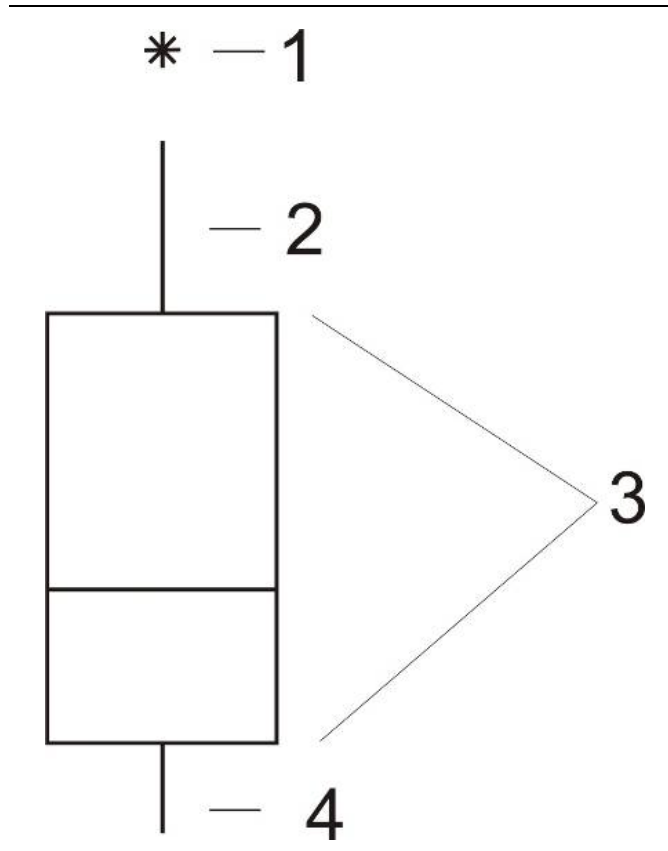

1 Outliers $\left(^{*}\right)$ - Dados que estão além dos bigodes (superior e inferior);

2 Bigode superior - Estende-se até o dado que esteja acima a 1,5x o tamanho da caixa (intervalo interquartis), a partir de sua linha superior ou o valor máximo da amostra mas não mais que Q3+1,5(Q3-Q1);

3 Intervalo interquartis - $50 \%$ dos dados;

- Linha do topo - Q3 (terceiro quartil) ou percentil 75\% (75\% dos dados são menores ou iguais a este valor);

Linha do meio - Q2 (mediana) ou percentil $50 \%$ (mediana);

- Linha de base - Q1 (primeiro quartil) ou percentil 25\%;

4 Bigode inferior - Estende-se até o dado que esteja abaixo a 1,5x o tamanho da caixa (intervalo interquartis), a partir de sua linha inferior ou o valor mínimo da amostra mas não menos que Q1-1,5(Q3-Q1);

Figura 29 - Esquema de um diagrama em caixa (boxplot), ferramenta de estatística descritiva utilizado neste trabalho.

\section{Correlação linear}

Foram utilizados diagramas de dispersão binária, em conjunto com análise de correlação linear, incluindo construção de retas de regressão para cada par de parâmetros granulométricos e de fração grossa (análise sob lupa).

Os valores de coeficiente de correlação linear $(r)$ e as retas de regressão foram obtidos com o Software Excel, versões 2003 e 2007. O critério estatístico utilizado para avaliar os resultados de $r$ foi o nível de significância ou erro I ( $\alpha$ ), correspondente à probabilidade de rejeitar uma hipótese nula $(\mathrm{HO})$ verdadeira. Como $\mathrm{H} 0$, no caso, afirma a inexistência de correlação significativa $(r \sim 0)$, a pode ser entendido como a probabilidade de aceitar-se uma correlação que na verdade não existe. Os valores máximos de a foram estimados por interpolação comparando o quociente $t$ do teste de regressão unicaudal $\left(t=r\left[(n-2)^{1 / 2} /\left(1-r^{2}\right)^{1 / 2}\right]\right)$ com a distribuição t de Student (Giannini et al, 2004). Para efeito de discussão de resultados, foram consideradas neste artigo as correlações lineares com nível de significância menor ou igual a 0,025 . 


\section{RESULTADOS}

\subsection{Descrição de fácies}

As fácies reconhecidas apresentam-se a seguir, reunidas por localização e origem (dominantemente antrópica ou geogênica) do depósito.

\subsubsection{Jabuticabeira}

A descrição de fácies na região de Jabuticabeira, município de Jaguaruna, foi realizada nas seções verticais dos lócus 1 e 2 do sambaqui Jabuticabeira II e em trincheiras abertas em sedimentos geogênicos próximos a este sambaqui (Figura 24).

Onze fácies foram identificadas no sambaqui, conforme descrição a seguir.

A $\ell$ - Areia fina a muito fina, quartzosa, cinza, de forma subtabular e espessura centimétrica (até $4 \mathrm{~cm}$ ), intercalada ritmicamente com lâminas milimétricas de bioclastos finamente fragmentados (menores que $5 \mathrm{~mm}$ ) de ossos e moluscos (principalmente mexilhão), com estrutura interna laminada. Os fragmentos de ossos apresentam forma alongada e/ou placóide, com cor amarelada ferrugem, parcialmente enegrecida. Em adição ao ritmito descrito, esta fácies possui lâminas compostas por cascalho bioclástico de ossos e moluscos, pardo-amarelado, forma subtabular, espessura centimétrica $(\sim 3 \mathrm{~cm})$, contendo conchas de Anomalocardia brasiliana inteiras ou fragmentadas, às vezes articuladas. Os fragmentos de conchas derivam aparentemente de sua alteração in situ, a julgar pelo destacamento de películas amarronzadas. Observa-se presença marcante de matéria orgânica particulada.

Lc - Argila preta rica em matéria orgânica (MO), com conchas inteiras e quebradas (predominantemente Anomalocardia brasiliana e subordinadamente Ostrea, menores que $10 \mathrm{~cm}$ ) e fragmentos de ossos, todos rudáceos. A forma é subtabular, com espessura centimétrica. Encontram-se distribuídos nesta fácies clastos centimétricos de argila e areia concentrados em bolsões e/ou lentes e, localmente, bolsões centimétricos a decimétricos de cinzas. O topo e/ou base podem ser marcados por maior concentração de MO carbonosa (possível carvão alterado). Na base, ocorrem também marcas cônicas. Esta fácies é correlata à "camada funerária" nos trabalhos de Klökler $(2001,2008)$ e Bendazzoli (2007).

Cb - Cascalho bioclástico dominado por conchas de Anomalocardia brasiliana, com boa seleção de tamanho. Predominam valvas desarticuladas, com concavidade voltada ora para cima ora para baixo. É marcante a presença de conchas de Thais em alguns horizontes e de 
Megabulinus em concentrações locais. Observam-se bolsões de areia subesféricos e arredondados ("bolas de areia"). Cor parda deve-se à impregnação das conchas por pelicula de argila rica em material provavelmente organo-fosfático. Esta fácies possui espessura centimétrica e forma aparente tabular.

CLb - Cascalho a grânulo e pequenos seixos, bioclástico, com argila rica em MO (pósdeposicional?). Os bioclastos são francamente dominados por moluscos quebrados, principalmente mexilhão, formando uma "farinha de concha". Notam-se clastos ou bolsões centimétricos de argila cinza ("bolas de lama") e presença eventual de fragmentos de carvão em níveis milimétricos ou de horizontes negros, carbonosos. Os fragmentos de carvão são semelhantes aos encontrados na fácies $\mathrm{C} \ell$. A camada de conchas de moluscos quebradas ocorre intercalada com cascalho bioclástico com areia quartzosa, espessura decimétrica, dominado por valvas quebradas e raramente inteiras de mexilhão, ossos de peixe fragmentados e, de modo subordinado, valvas quebradas e inteiras de Anomalocardia brasiliana. O contato basal, com fácies Lc, é brusco. A geometria é subtabular e a trama é em geral concordante com a camada, com exceções localizadas.

C $\ell$ - Cascalho bioclástico a grânulo e pequenos seixos, com areia quartzosa fina a muito fina. A forma da fácies é lenticular côncavo-plana, com espessura máxima de $5 \mathrm{~cm}$ e extensão lateral decimétrica. Observa-se laminação marcada pela isorientação de fragmentos de bioclastos. Estes bioclastos são, predominantemente, mexilhões finamente quebrados, com presença de Anomalocardia brasiliana e raros ossos de peixe. Fragmentos de carvão ocorrem dispersos.

A - Areia quartzosa fina a muito fina, amarronzada, com raros grãos placóides de carbonato bioclástico e com fragmentos milimétricos a centimétricos de carvão no topo. Ocorre em camadas com forma lenticular, espessura centimétrica (máximo de $5 \mathrm{~cm}$ ) e extensão lateral decimétrica. $\mathrm{O}$ contato é brusco na base e no topo, com fácies $\mathbf{C} \boldsymbol{\ell}$.

L - Silte argiloso com areia média cinza claro e grânulos de quartzo e bioclastos carbonáticos e fosfáticos. Ocorre em camadas com forma lenticular, espessura máxima centimétrica $(2 \mathrm{~cm})$, extensão lateral decimétrica e contato brusco na base com fácies $A$.

CAl - Cascalho bioclástico arenoso dominado por valvas inteiras de Anomalocardia brasiliana, com presença marcante de conchas de mexilhão, muitas vezes inteiras e articuladas. Apresenta estrutura interna laminada devido a isorientação dos fragmentos bioclásticos. Os bioclastos apresentam-se em trama caótica, com ligeiro domínio de orientação concordante ao acamamento. Ocorre em camadas com geometria lenticular 
irregular, extensão lateral métrica, espessura centimétrica a decimétrica e contato amalgamado com fácies CLb no topo.

CL $\ell$ - Cascalho bioclástico cinza escuro, com areia quartzosa amarela, torrões centimétricos de argila alaranjada com microfósseis e concreções de material carbonático (cal carbonatada ?). Apresenta estrutura interna laminada devido a isorientação dos fragmentos bioclásticos. A forma é lenticular plano-convexa inclinada ou em bolsões, em espessura centimétrica a decimétrica, sempre exibindo contatos bruscos com as fácies adjacentes.

LA - Argila com cascalho bioclástico e areia quartzosa, passando acima, de modo gradual, a argila com areia e cascalho bioclástico. Os bioclastos são compostos por ossos de peixe e moluscos, com franco predomínio, dentre estes, de Anomalocardia brasiliana e mexilhão fragmentado. Nota-se presença marcante de objetos líticos centimétricos a decimétricos e de fragmentos de carvão. A forma é lenticular, de topo aparentemente plano, com espessura métrica. Esta fácies é correlata à "terra preta" dos trabalhos de Bendazzoli (2007) e Villagrán (2008).

Ap - Areia cinza amarelado claro, fina a muito fina, com cascalho bioclástico em intercalação rítmica centimétrica com material carbonoso contendo conchas queimadas (cinza). O material bioclástico é constituído por conchas fragmentadas e inteiras de Anomalocardia brasiliana e outras espécies não identificadas. Observa-se presença de ossos em algumas lâminas mais amareladas. Ocorre em camadas com forma subtabular, de espessura e extensão lateral métrica. 
Tabela 5 - Resumo da descrição de campo das fácies do sambaqui Jabuticabeira II.

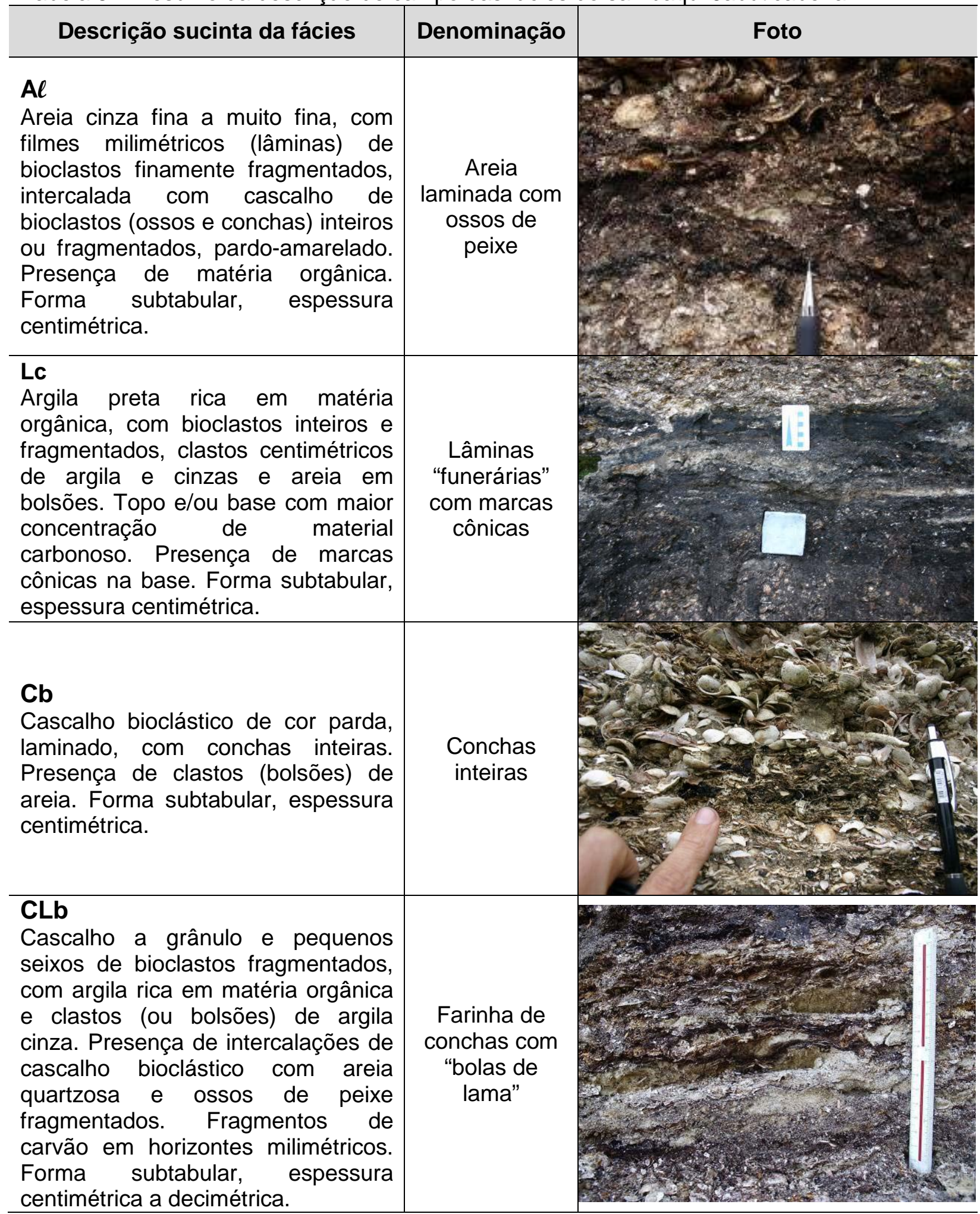


Tabela 8 - Resumo da descrição de campo das fácies do sambaqui Jabuticabeira II.. Continuação.

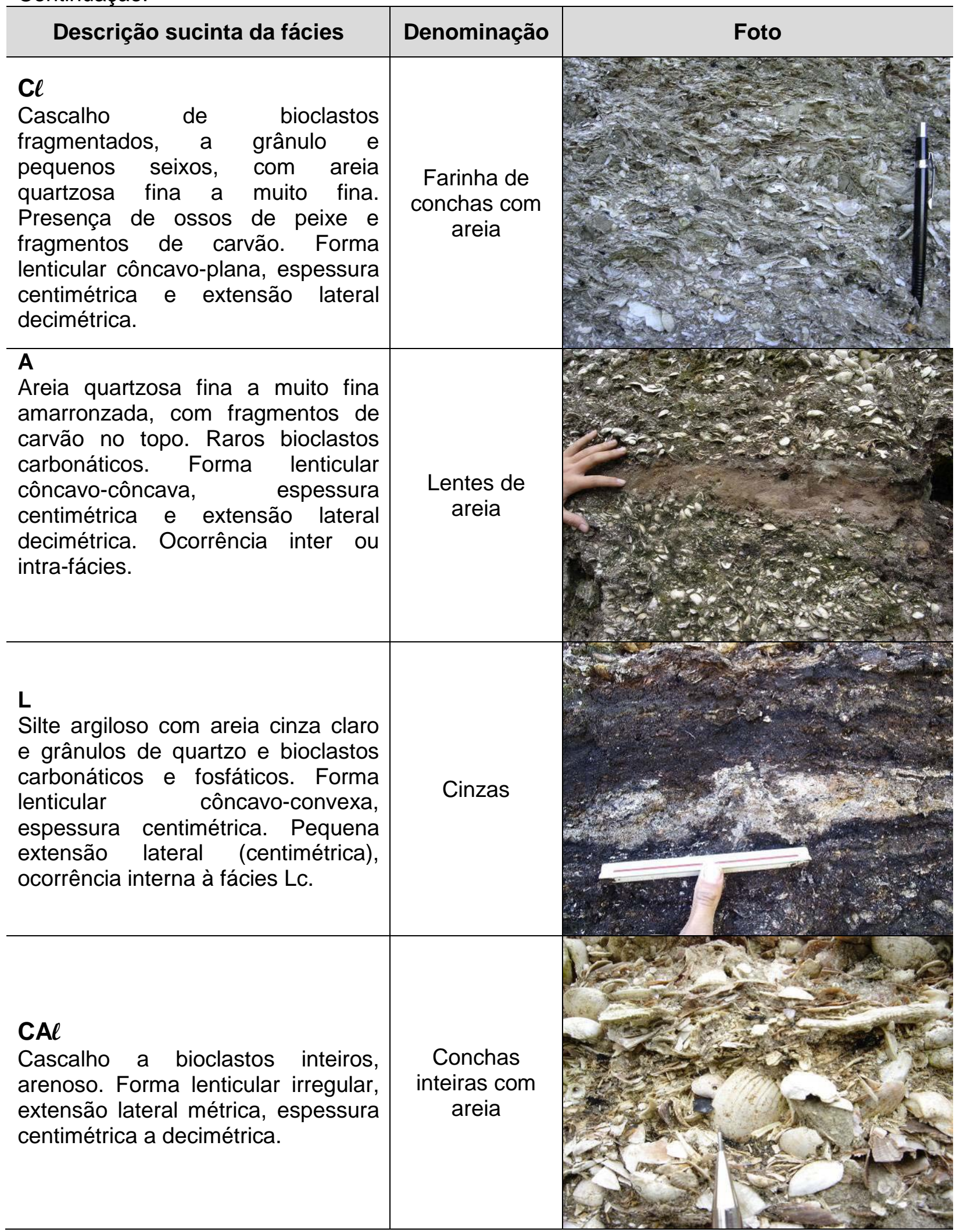


Tabela 8 - Resumo da descrição de campo das fácies do sambaqui Jabuticabeira II. Continuação.

\begin{tabular}{|c|c|c|}
\hline Descrição sucinta da fácies & Denominação & Foto \\
\hline $\begin{array}{l}\text { CLe } \\
\text { Cascalho bioclástico cinza escuro, } \\
\text { com areia quartzosa amarela. } \\
\text { Torrões de argila alaranjada com } \\
\text { microfósseis e concreções } \\
\text { carbonáticas. Forma lenticular } \\
\text { plano-convexa inclinada, espessura } \\
\text { centimétrica a decimétrica. } \\
\text { Semelhante à porção de conchas } \\
\text { queimadas acinzentadas da fácies } \\
\text { Ap, exceto pela geometria lenticular } \\
\text { e pela presença de torrões de argila. }\end{array}$ & Conchas cinza & \\
\hline $\begin{array}{l}\text { LA } \\
\text { Argila com cascalho bioclástico e } \\
\text { areia quartzosa, passando acima, de } \\
\text { modo gradual, a argila com areia e } \\
\text { cascalho bioclástico. Presença } \\
\text { marcante de objetos líticos e } \\
\text { fragmentos de carvão. Forma } \\
\text { lenticular de topo plano e espessura } \\
\text { métrica. }\end{array}$ & $\begin{array}{l}\text { "Terra preta" } \\
\text { com líticos, } \\
\text { rica em ossos }\end{array}$ & \\
\hline $\begin{array}{l}\text { Ap } \\
\text { Areia cinza amarelado claro, fina a } \\
\text { muito fina, com cascalho bioclástico } \\
\text { fragmentado em intercalação rítmica } \\
\text { centimétrica com material } \\
\text { carbonoso, este contendo conchas } \\
\text { queimadas de cor cinza. Presença } \\
\text { de lâminas amarelas ricas em } \\
\text { ossos. Forma subtabular, espessura } \\
\text { e extensão lateral métrica. }\end{array}$ & $\begin{array}{c}\text { Areia em } \\
\text { estratificação } \\
\text { rítmica com } \\
\text { material } \\
\text { carbonoso e } \\
\text { conchas cinza }\end{array}$ & \\
\hline
\end{tabular}


O exame da seção colunar A (Figuras 30 e 31) permite notar o predomínio de intercalações rítmicas de camadas conchíferas com níveis carbonosos, sendo esta a característica principal da fácies Ap. Esta fácies acunha-se para $W$ em direção à seção $B$ (Figura 32), onde ocorre no meio da coluna. A fácies Ap encontra-se associada às fácies $\mathrm{C} l \mathrm{e}$ Lc, as quais se intercalam ritmicamente entre si, com maior regularidade na base da seção B.

Desse modo, o lócus 1 caracteriza-se pela associação das fácies Ap, Lc e C $\ell$. Destacase o predomínio de fácies bioclásticas cascalhosas com areia fina (Ap e Cl), principalmente na seção $A$, e a maior espessura da fácies $L c$ e $L A$, na seção $B$, em comparação com a seção do lócus 2 (L2).

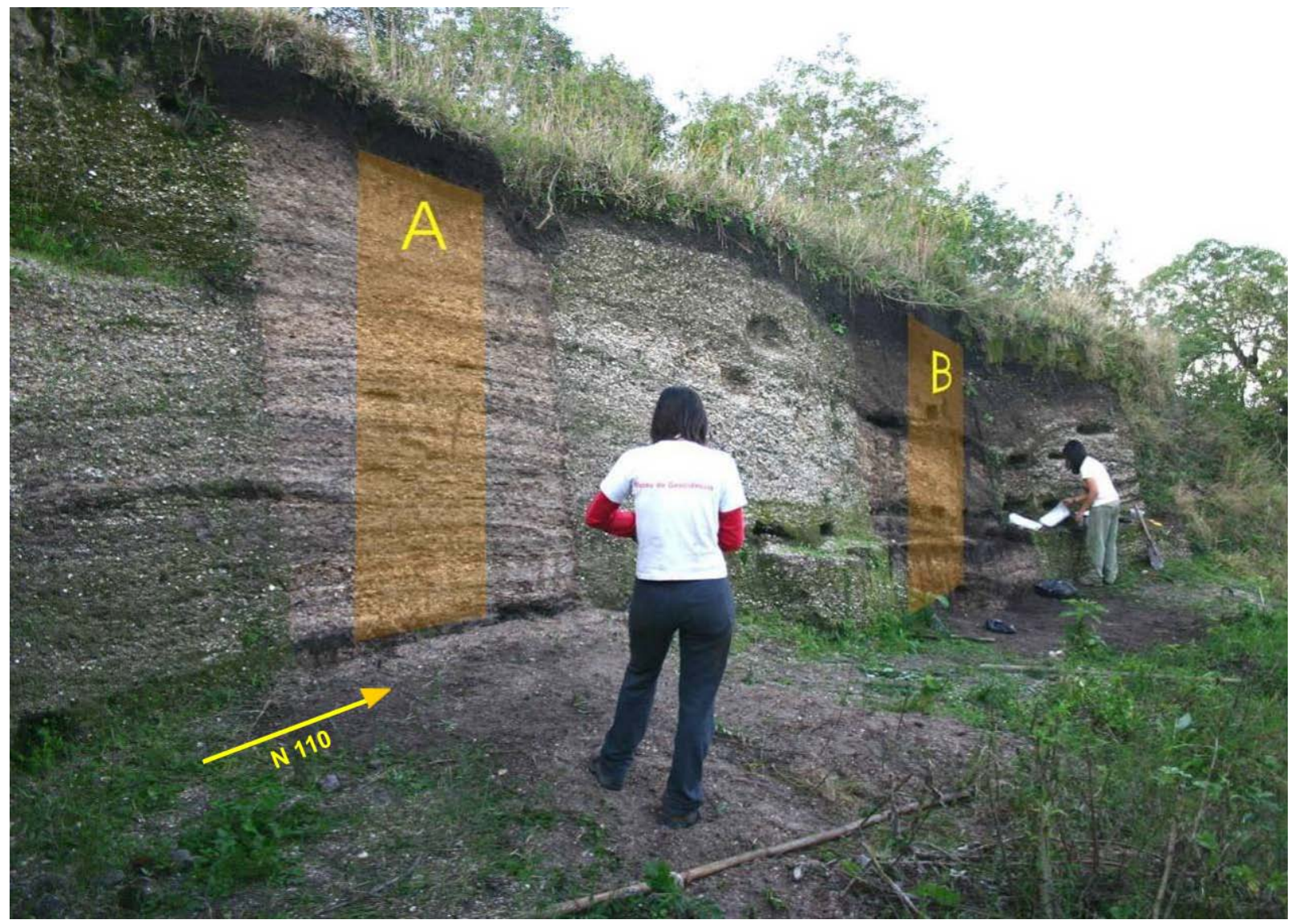

Figura 30 - Localização das seções colunares (A e B) levantadas para o lócus 1 do sambaqui Jabuticabeira II. Ver seções colunares A e B nas Figuras 31 e 32, respectivamente. 


\section{Seção}

(A)

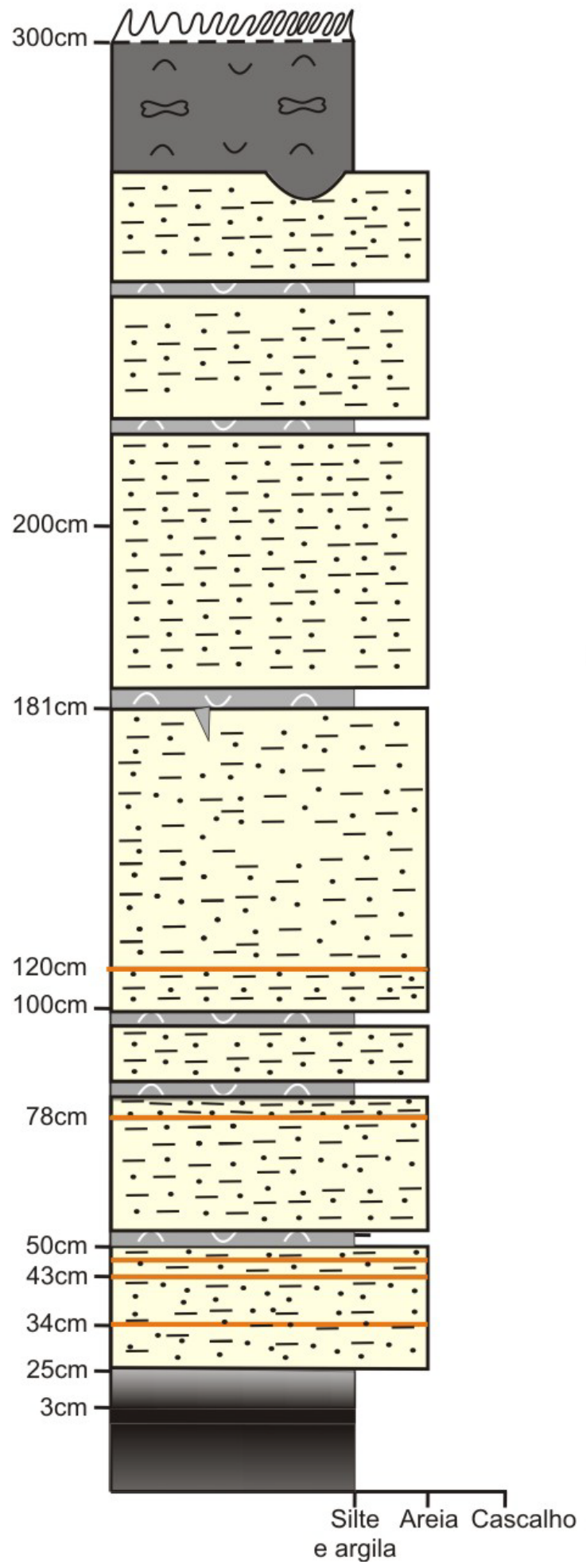

\section{LEGENDA}

Fácies

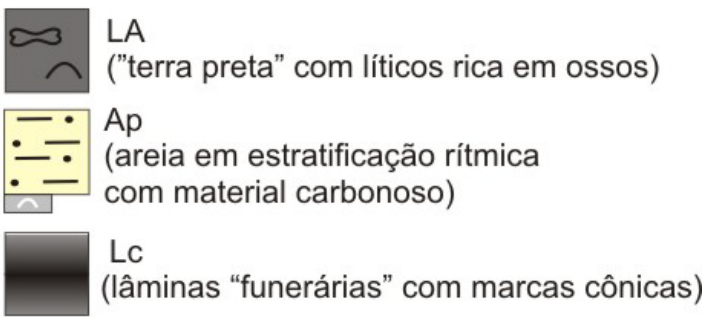

Símbolos

- - Conchas fragmentadas

$\because$ Areia

$\approx$ Fragmentos de ossos

$\frown$ Conchas inteiras

— Lâmina rica em ossos

7 Marca cônica

Figura 31 - Seção colunar de parte da seção exposta no lócus 1, do sambaqui Jabuticabeira II. Correspondente à coluna A da Figura 30. 


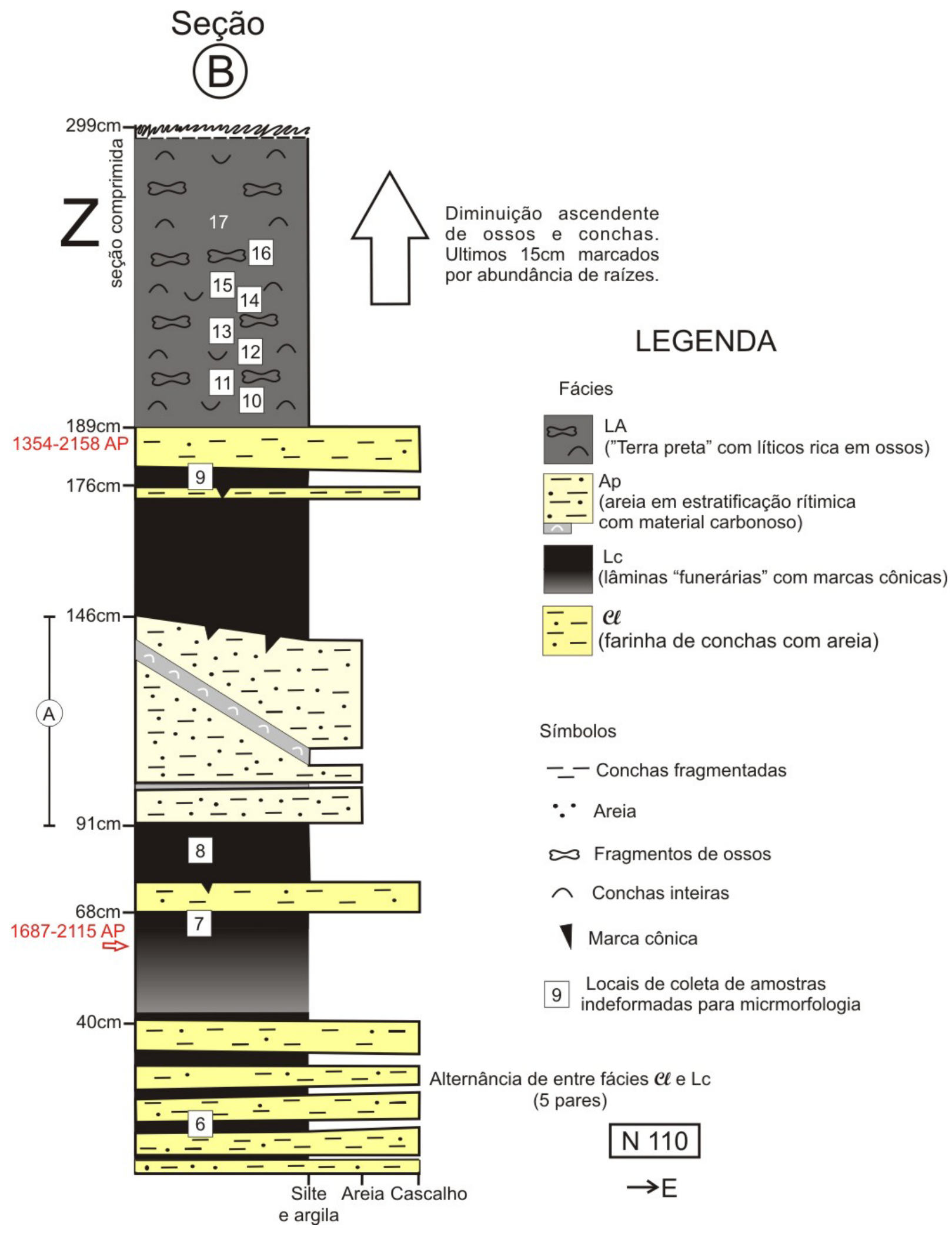

Figura 32 - Seção colunar de parte da seção exposta no lócus 1, do sambaqui Jabuticabeira II. Correspondente à coluna B da Figura 30. 
A parede exposta do lócus 2 encontra-se entre 100 e $140 \mathrm{~cm}$ topograficamente abaixo da parede do lócus 1, segundo as seções estratigráficas de Bendazzoli (2007). Este desnível topográfico, associado à aparente continuidade estratigráfica destes dois lócus segundo um único depósito monticular (mound), permite admitir que as fácies do terço a metade superior do lócus 1, organizadas nas seções A e B (Figura 31 e Figura 32), estão estratigraficamente acima das do lócus 2 (seção colunar L2, Figura 34), com sobreposição ou correlação direta entre a parte restante (inferior) das seções A e B e a parte superior da seção L2.

Nota-se, a partir da observação da seção colunar L2 (Figura 34), predomínio de fácies com componente lamoso (fácies CLb) na base, com tendências, rumo ao topo, para aumento da representatividade de fácies com componente arenoso (fácies $\mathrm{Cl}$ e $\mathrm{CA} \ell$ ) e para diminuição na freqüência da fácies Lc.

Nesta seção, as fácies podem ser organizadas em três associações: na base, ocorre associação de fácies com caráter cascalho-lamoso, composta por Cb, Lc e CLb; no intervalo intermediário da coluna (entre 159 e 225cm), passa-se a associação de fácies com caráter areno-lamoso, constituída por $\mathrm{C} \boldsymbol{\ell}, \mathrm{Lc}, \mathrm{CA} \boldsymbol{\ell}$ e $\mathrm{CL} \boldsymbol{\ell}$; e no intervalo de topo, à associação de fácies com caráter cascalho-arenoso, composta por $\mathrm{C} \ell$ e CAl. As associações de fácies encontram-se limitadas pela fácies Lc (lâminas "funerárias" com marcas cônicas), que representam superfícies contínuas lateralmente e recorrentes ao longo da seção, comparáveis às superfícies delimitantes de elementos arquitetônicos ou associações de fácies (sensu Miall, 1985), conforme mencionado no item 3.2.4.

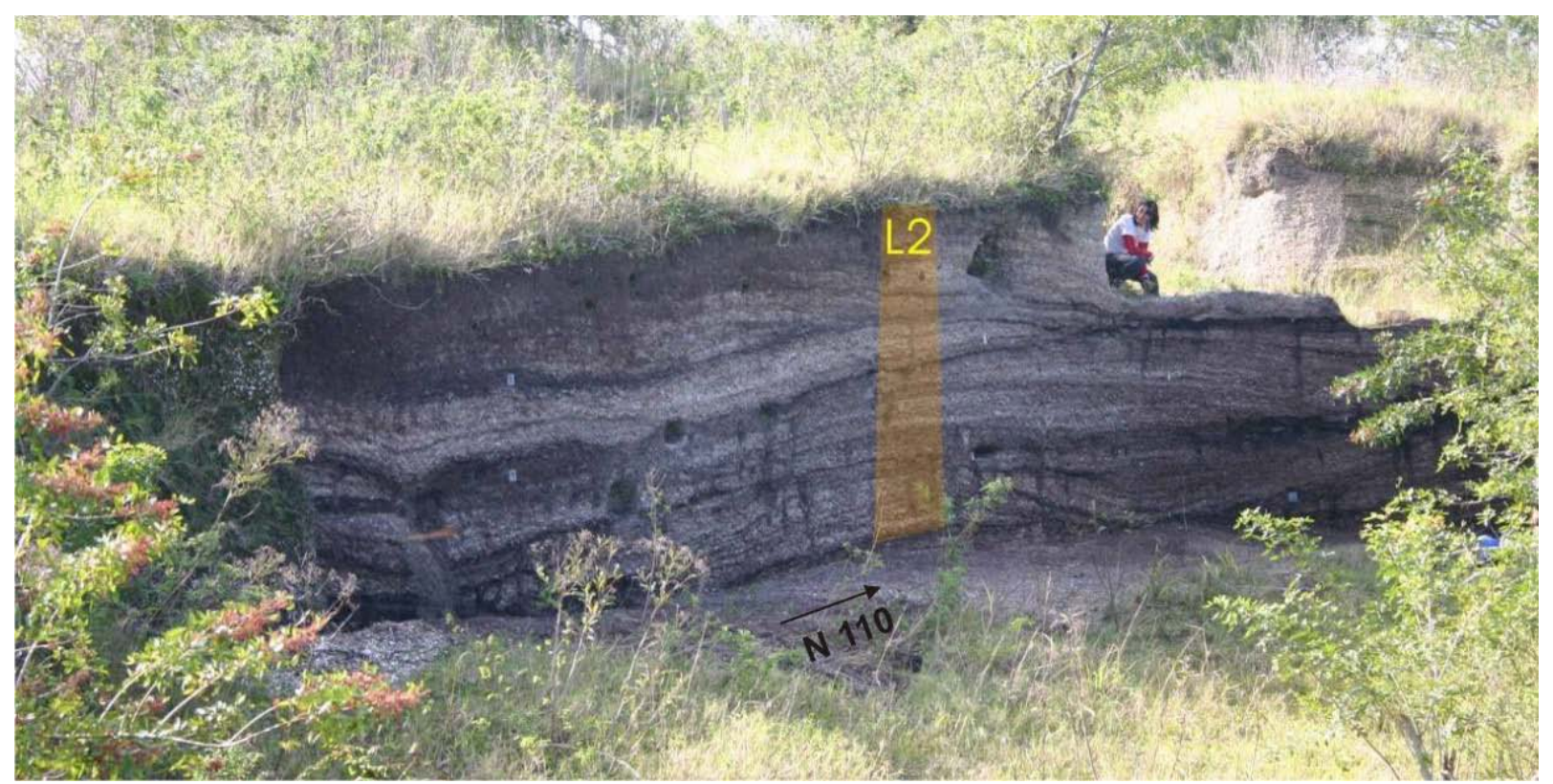

Figura 33 - Localização da seção colunar L2 de parte da seção exposta no lócus 2, do sambaqui Jabuticabeira II.Ver seção colunar L2 na Figura 34. 
L2

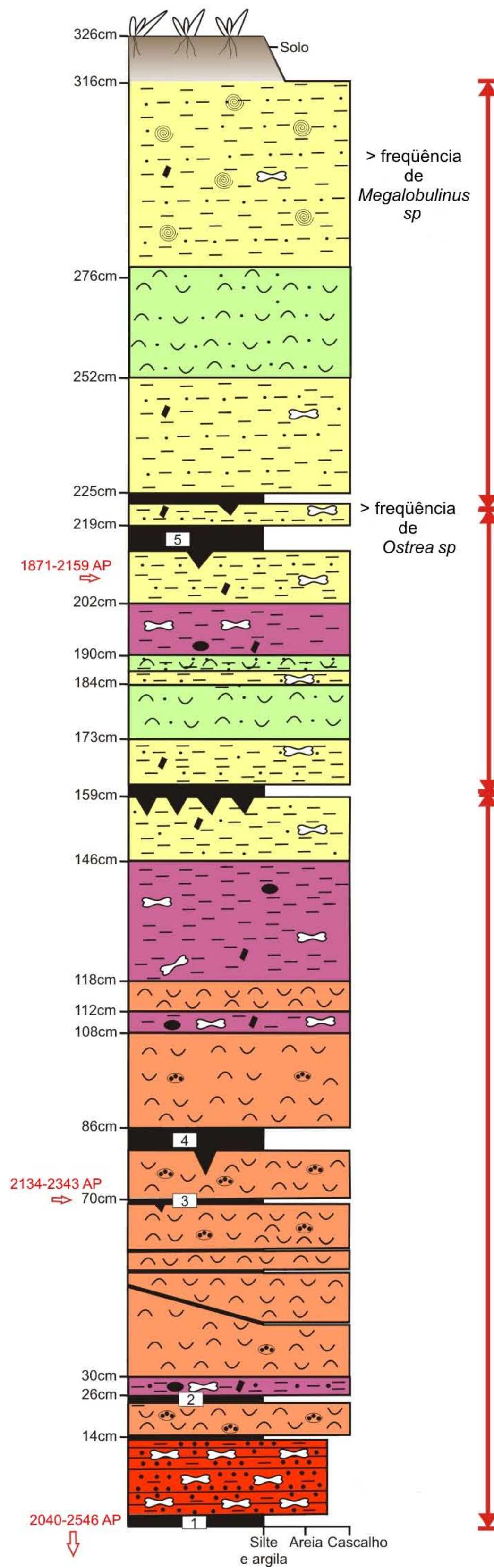

Associação de fácies

cascalho-arenosas

Associação de fácies

areno-lamosas
Símbolos

- - Conchas fragmentadas

$\because$ Areia

$\approx$ Fragmentos de ossos

$\frown$ Conchas inteiras

$\checkmark$ Marca cônica

2 Local de coleta de amostra indeformada para micrmorfologia

(C) Megalobulinus $s p$

Clastos ("bolas") de areia

Clastos ("bolas") de argila

Fragmentos de carvão

\section{Associação de fácies}

cascalho-lamosas 
Sedimentos geogênicos do entorno do sambaqui Jabuticabeira II - fácies e seções colunares

Os sedimentos geogênicos do entorno do sambaqui Jabuticabeira II (localização na Figura 24) podem ser divididos em duas fácies: a arenosa, com ou sem cascalho conchífero, e a areno-lamosa, também com ou sem cascalho conchífero. Na fácies arenosa, o cascalho conchífero inclui tanto bioclastos como possíveis fósseis em posição de vida, e sua concentração decresce rumo ao topo. Na fácies areno-lamosa, o cascalho corresponde a bioclastos. Estas duas fácies encontram-se associadas de forma semelhante em todas as trincheiras analisadas, sendo sua associação interpretada e designada como paleolagunar: a fácies arenosa corresponderia a fundo ou praia lagunar, de mais alta energia relativa, e a fácies areno-lamosa, a deposição em brejos de laguna assoreada. As descrições completas destas fácies encontram-se na Tabela 6 e suas representações em seções colunares, ilustradas por fotos, apresentam-se nas Figura 35 a Figura 43.

Tabela 6 - Resumo da descrição de campo das fácies dos sedimentos geogênicos próximos ao sambaqui Jabuticabeira II.

\begin{tabular}{l|c}
\hline \multicolumn{1}{c|}{ Descrição sucinta da fácies } & Denominação \\
\hline $\begin{array}{l}\text { Areia fina a muito fina cinza escuro, com matéria orgânica coloidal } \\
\text { e particulada e raros bioclastos. Forma tabular e contato abrupto } \\
\text { ou transicional na base. Presença eventual de lâmina centimétrica } \\
\text { argilosa basal e descontínua, cor cinza escuro, mais marcada à } \\
\text { medida que se aproxima da laguna Garopaba do Sul. }\end{array}$ & Areia lamosa \\
\hline $\begin{array}{l}\text { Areia fina cinza esbranquiçado, com redução ascendente na } \\
\text { quantidade de bioclastos (fragmentados e inteiros). }\end{array}$ & Areia \\
\hline
\end{tabular}




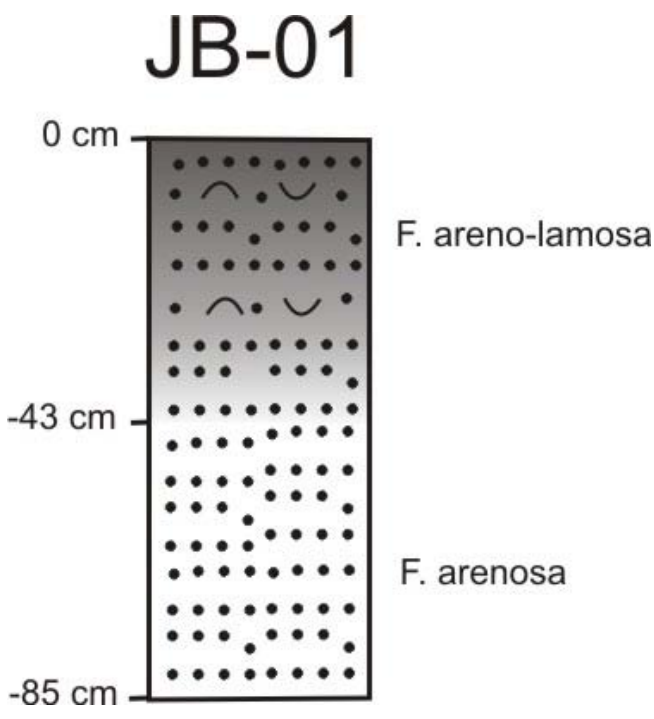

Figura 35 - Seção colunar da trincheira (JB01) em sedimento geogênico, $60 \mathrm{~m}$ a NE do sambaqui Jabuticabeira II (Figura 24).

Figura 36 - Trincheira (JB-01) em sedimento geogênico, $60 \mathrm{~m}$ a NE do sambaqui Jabuticabeira II. Em amarelo, os códigos de amostragem de cada fácies (JB-01 $\alpha$ e $\beta$ ).

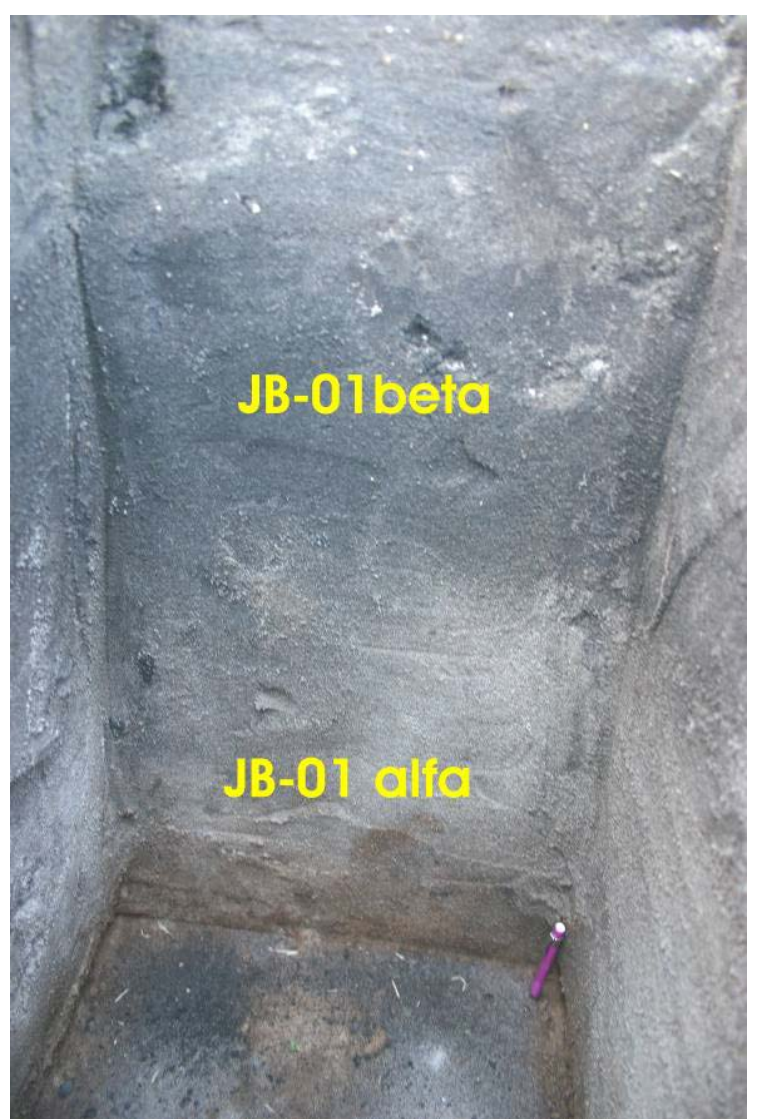




\section{JB-02}

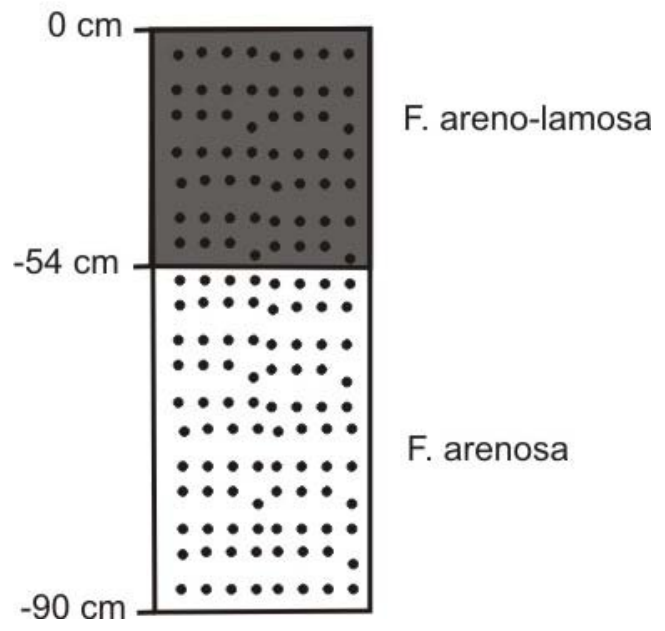

Figura 37 - Seção colunar de trincheira (JB02) em sedimento geogênico, $70 \mathrm{~m}$ a NE do sambaqui Jabuticabeira II (Figura 24).

Figura 38 - Trincheira (JB-02) em sedimento geogênico, $70 \mathrm{~m}$ a NE do sambaqui Jabuticabeira II. Em amarelo, os códigos de amostragem de cada fácies (JB-02 $\alpha$ e $\beta$ ).

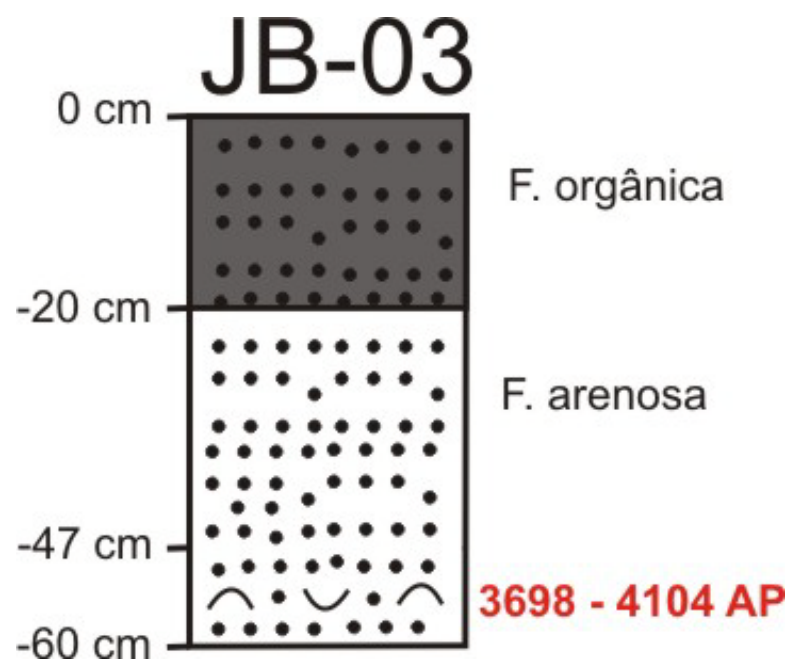

Figura 39 - Seção colunar de trincheira (JB03) em sedimento geogênico, aproximadamente $80 \mathrm{~m}$ a NE do sambaqui Jabuticabeira II (Figura 24).

Figura 40 - Trincheira (JB-03) em sedimento geogênico, aproximadamente 80m a NE do sambaqui Jabuticabeira II. Em amarelo, os códigos de amostragem de cada fácies (JB$03 \alpha$ e $\beta)$.
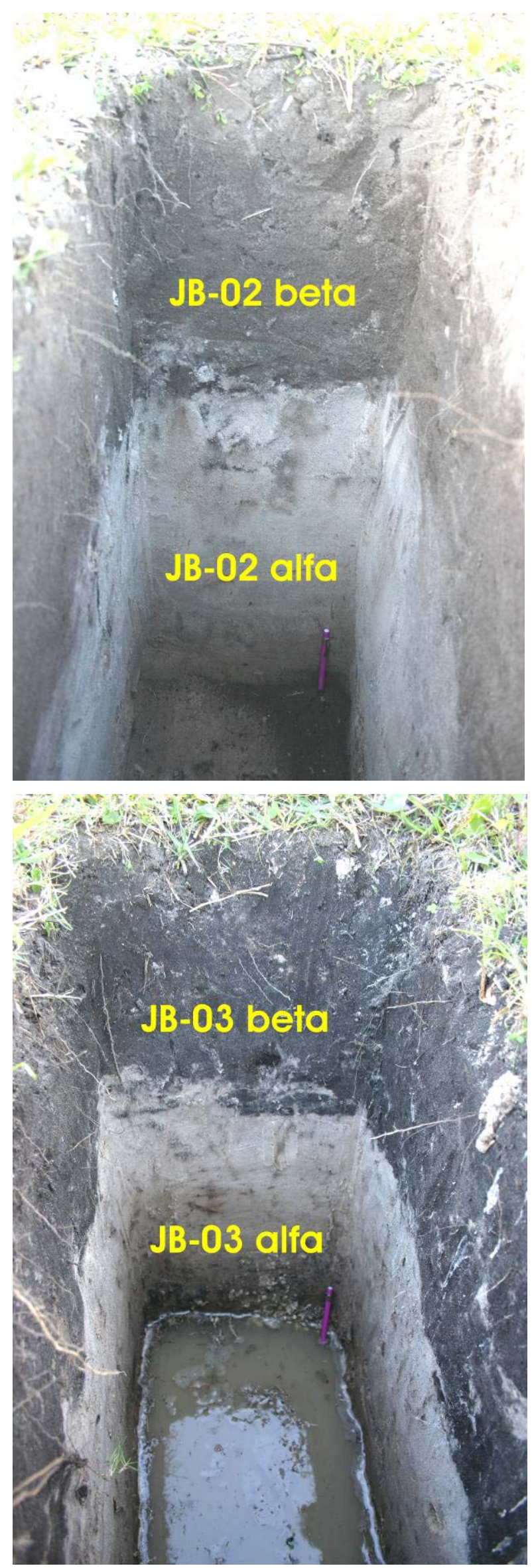


\section{JB-04}

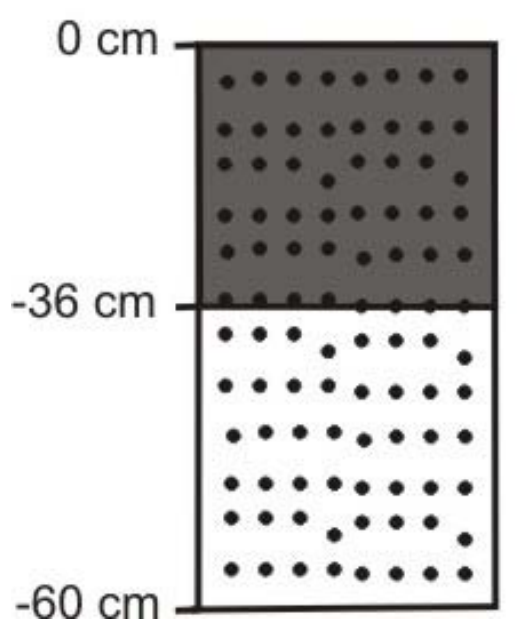

F. areno-lamosa

F. arenosa

Figura 41 - Seção colunar de trincheira (JB-04) em sedimento geogênico, 90m a NE do sambaqui Jabuticabeira II (Figura 24).

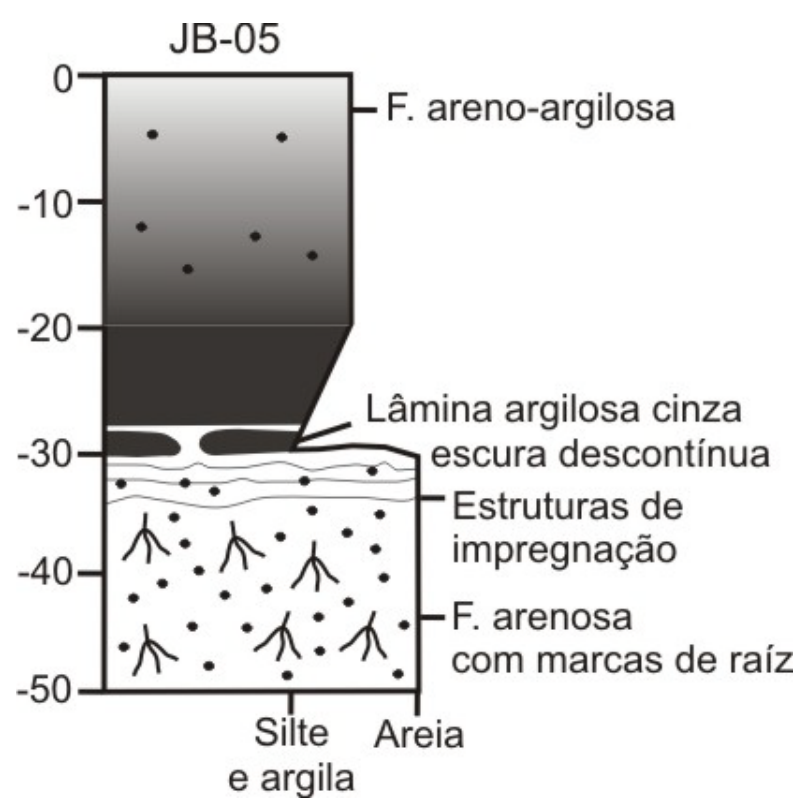

Figura 42 - Seção colunar de trincheira (JB05) em sedimento geogênico, aproximadamente $200 \mathrm{~m}$ a NE do sambaqui Jabuticabeira II (Figura 24). Notar estruturas de impregnação (sensu Yaalon \& Fränzle, 1975) e marcas de raízes na fácies arenosa.

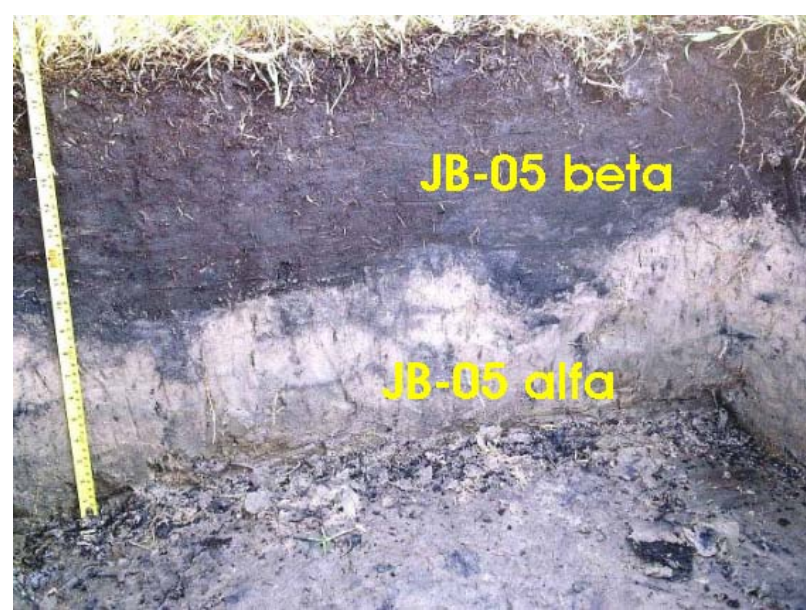

Figura 43 - Trincheira (JB-05) em sedimento geogênico paleolagunar, distante 200 a $250 \mathrm{~m}$ do sambaqui Jabuticabeira II. Em amarelo, os códigos de amostragem de cada fácies (JB-05 $\alpha$ e $\beta$ ). 


\subsubsection{Garopaba do Sul}

A descrição de fácies na região de Garopaba do Sul foi realizada em seção aberta na ocasião no sambaqui Encantada III, e em trincheira e vala de carcinicultura escavadas nos sedimentos geogênicos próximos (900 e 50m, respectivamente) a este sambaqui (Figura 25).

Duas fácies foram identificadas: areia, no seu núcleo monticular, e "terra preta", na camada concordante de topo. As descrições das duas fácies encontram-se na Tabela 7, com ilustração em foto na Figura 44.

Tabela 7 - Resumo da descrição de campo das fácies do sambaqui Encantada III.

\begin{tabular}{l|c}
\hline \multicolumn{1}{c|}{ Descrição sucinta da fácies } & Denominação \\
\hline $\begin{array}{l}\text { Areia lamosa com matéria orgânica particulada com cascalho } \\
\text { bioclástico (predominantemente Anomalocardia brasiliana) e }\end{array}$ & "Terra preta" \\
$\begin{array}{l}\text { areia. Forma subtabular, convexa na base e no topo, } \\
\text { concordante com o topo da fácies subjacente. Contato basal } \\
\text { brusco. }\end{array}$ & \\
\hline $\begin{array}{l}\text { Areia fina amarelada, maciça. Forma lenticular plano-convexa } \\
\text { (monticular, semelhante a uma duna). }\end{array}$ & Areia \\
\hline
\end{tabular}

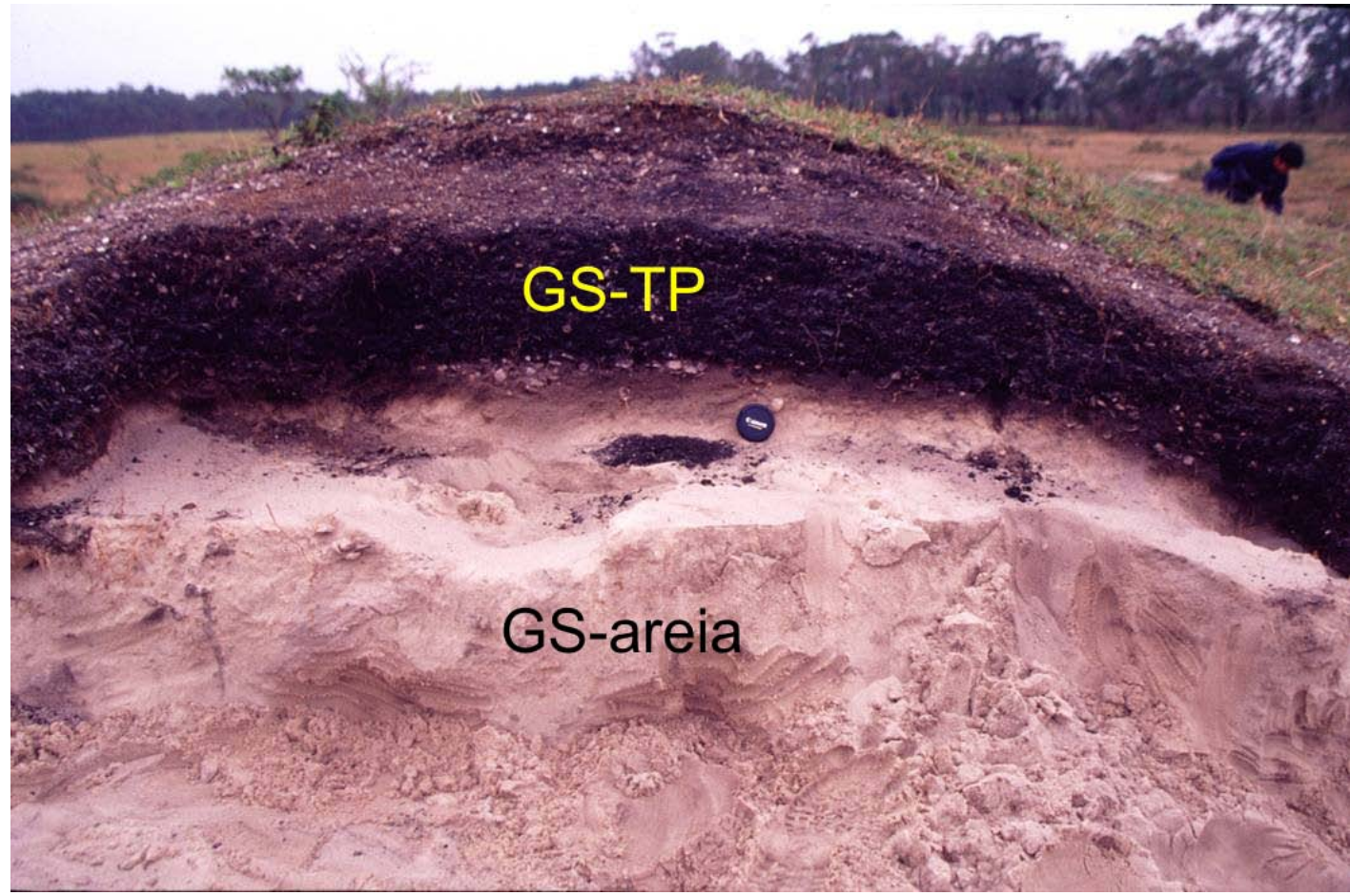

Figura 44 - Exposição em trincheira aberta na porção mais alta do sambaqui Encantada III. Estão representados em preto/amarelo os códigos de amostragem. Foto: Paulo C. F. Giannini. 
Sedimentos geogênicos do entorno do sambaqui Encantada III

Os sedimentos geogênicos do entorno do sambaqui Encantada III (localização na Figura 25) podem ser divididos em duas fácies similares às encontradas próximo ao sambaqui Jabuticabeira II (final do item 5.1.1): a arenosa, com ou sem cascalho bioclástico, e a areno-lamosa, com ou sem cascalho bioclástico. Estas duas fácies encontram-se descritas na Tabela 8. Na fácies arenosa, o cascalho conchífero inclui mais uma vez tanto bioclastos como possíveis fósseis em posição de vida, e sua concentração decresce rumo ao topo. $\mathrm{Na}$ fácies areno-lamosa, este material corresponde a bioclastos. A distribuição destas fácies em seção colunar e foto podem ser observadas na Figura 45 e na Figura 46. As duas fácies encontram-se associadas de forma semelhante em todas as trincheiras analisadas. Esta associação de fácies foi interpretada como paleolagunar, de modo análogo ao visto na região do sítio Jabuticabeira II. Assim, a fácies arenosa corresponderia a fundo ou praia lagunar e a fácies areno-lamosa, a deposição em brejos de laguna assoreada.

Tabela 8 - Resumo da descrição de campo das fácies dos sedimentos geogênicos próximo ao sambaqui Encantada III.

\section{Descrição sucinta da fácies}

Denominação

Areia argilosa preta, com matéria orgânica coloidal e particulada, maciça. Presença de detritos vegetais (principalmente raízes). Areia lamosa Forma tabular. Contato brusco na base.

Areia fina a média bege, maciça, com diminuição da freqüência de ocorrência de conchas (predominantemente inteiras e subcentimétricas a centimétricas) rumo ao topo. Granodecrescência ascendente da fração areia. Presença de Areia lentes de cascalho bioclástico. Forma tabular. 


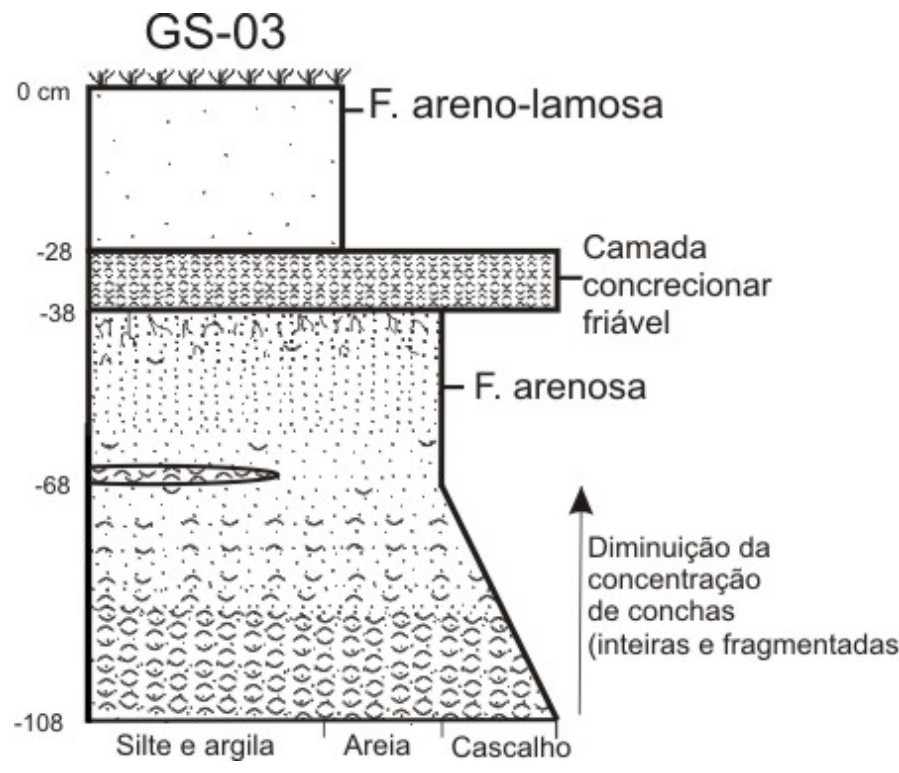

Figura 45 - Seção colunar e descrição de fácies na trincheira GS03, em sedimentos geogênicos, aproximadamente $900 \mathrm{~m}$ a NW do sambaqui Encantada III (Figura 25). A exposição descrita na vala de carcinicultura (GS-01), distante aproximadamente $50 \mathrm{~m}$ do sambaqui Encantada III, possui configuração estratigráfica muito semelhante à desta trincheira.

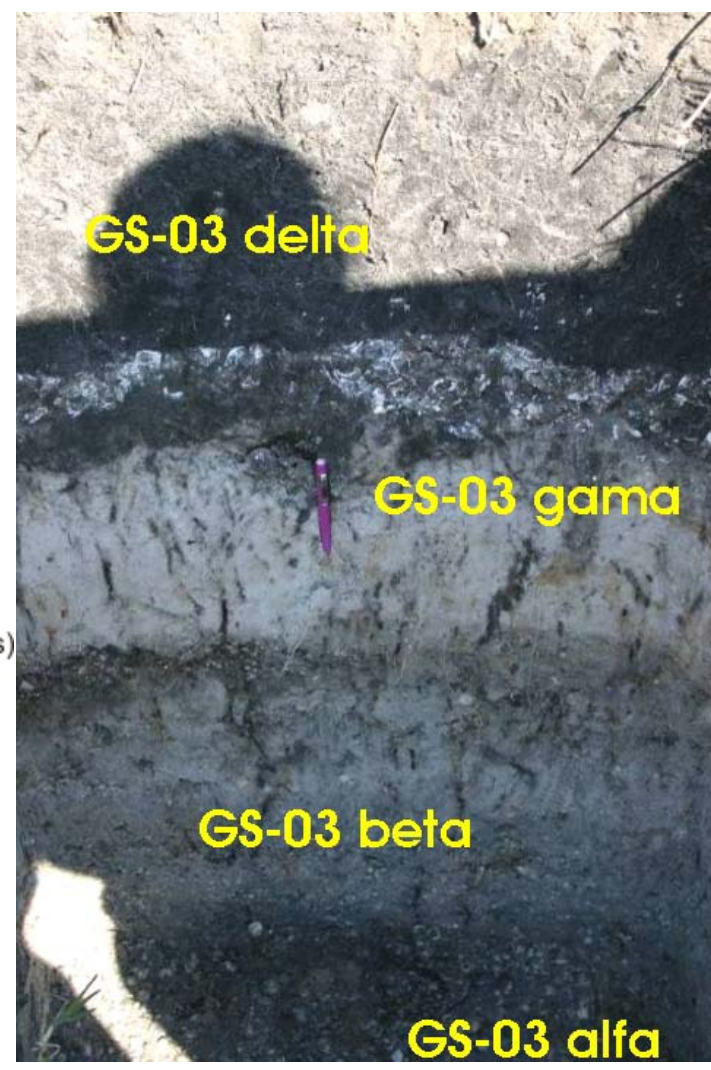

Figura 46 - Trincheira GS03 em sedimentos geogênicos, aproximadamente $900 \mathrm{~m}$ a NW do sambaqui Encantada III. Em amarelo, indicação dos códigos de amostragem (GS-03 $\alpha, \beta$, y e $\delta$ ).

\subsubsection{Campos Verdes}

A descrição de fácies em Campos Verdes foi realizada em seção aberta na ocasião no sambaqui Carniça III e em trincheira escavada em sedimentos geogênicos em área próxima (10m) ao sambaqui Carniça I (Figura 26).

À semelhança do sítio Encantada III, apenas duas fácies foram identificadas no sambaqui Carniça III: a fácies areia, no núcleo monticular do sambaqui, e a fácies "terra preta", na camada de topo. As descrições das fácies apresentam-se na Tabela 9 e a representação em seção colunar, ilustrada por fotografia, encontra-se nas Figura 47 e Figura 48. 
Tabela 9 - Resumo da descrição de campo das fácies do sambaqui Carniça III.

\begin{tabular}{l|c}
\hline \multicolumn{1}{c|}{ Descrição sucinta da fácies } & Denominação \\
\hline $\begin{array}{l}\text { Areia argilosa com matéria orgânica (particulada), carvão e } \\
\text { conchas (predominantemente Anomalocardia brasiliana), matriz- } \\
\text { sustentada. Contato brusco na base. }\end{array}$ & "Terra preta" \\
\hline $\begin{array}{l}\text { Areia fina bege levemente amarelada, maciça. Forma lenticular } \\
\text { aparentemente plano-convexa (monticular, semelhante a uma } \\
\text { duna). }\end{array}$ & Areia \\
\hline
\end{tabular}

\section{Carniça III}

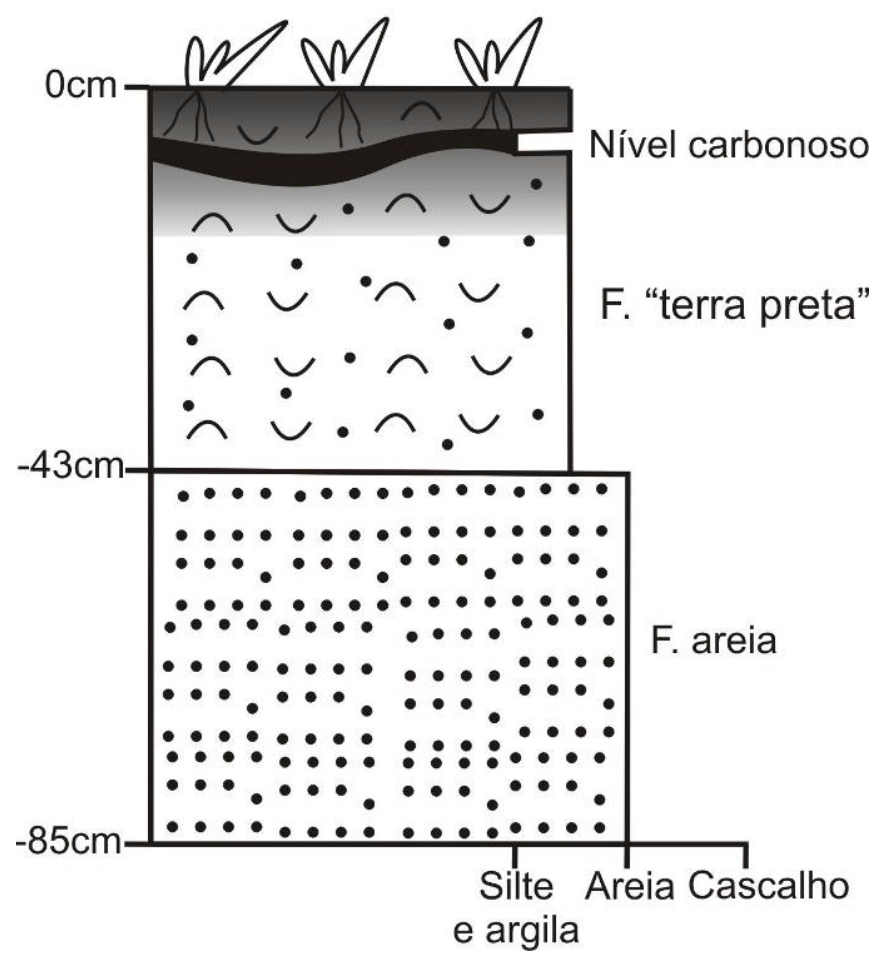

Figura 47 - Seção colunar e descrição de fácies de trincheira no sambaqui Carniça III (Figura 26).

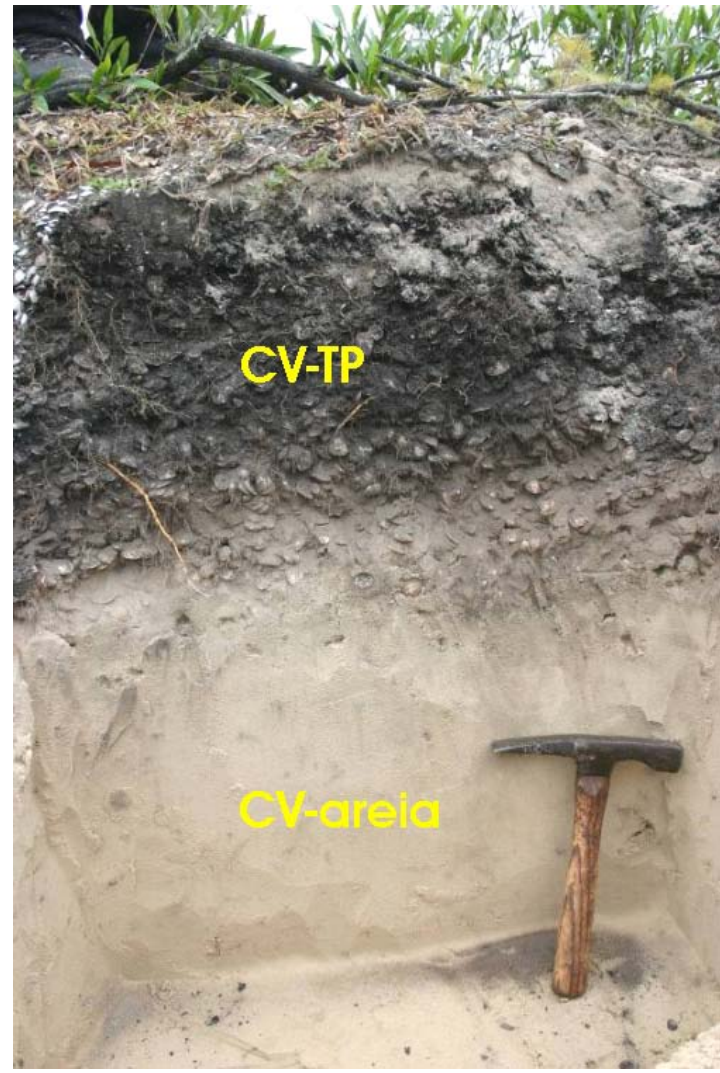

Figura 48 - Trincheira no topo do sambaqui Carniça III. 
Sedimentos geogênicos do entorno dos sambaquis Carniça I e Carniça III

Os sedimentos geogênicos do entorno dos sambaquis Carniça I e Carniça III (localização na Figura 26) podem ser divididos em duas fácies: a arenosa, com ou sem cascalho bioclástico, e a areno-lamosa, com ou sem cascalho bioclástico. Na fácies arenosa, o cascalho conchífero inclui mais uma vez tanto bioclastos como possíveis fósseis em posição de vida, e sua concentração decresce rumo ao topo, conforme visualizado nas Figura 49 e na Figura 50. Na fácies areno-lamosa, este material corresponde a bioclastos. As duas fácies encontram-se associadas de forma semelhante em todas as trincheiras analisadas e suas descrições acham-se na Tabela 10. Esta associação de fácies foi interpretada como paleolagunar, de modo comparável ao já discutido para as regiões dos sítios Jabuticabeira II e Encantada III.

Tabela 10 - Resumo da descrição de campo das fácies dos sedimentos geogênicos próximo aos sambaquis Carniça I e Carniça III.

\begin{tabular}{l|c}
\hline \multicolumn{1}{c|}{ Descrição sucinta da fácies } & Denominação \\
\hline $\begin{array}{l}\text { Areia argilosa com matéria orgânica particulada e coloidal preta } \\
\text { com fragmentos vegetais pretos (granulação cascalho), } \\
\text { dispersos. Aumento do conteúdo orgânico para o topo. Contato }\end{array}$ & Areia lamosa \\
gradual na base. Forma tabular. & \\
\hline $\begin{array}{l}\text { Areia fina a muito fina, cinza escuro a claro, com lentes de } \\
\text { cascalho bioclástico no topo. O cascalho bioclástico é composto } \\
\text { por conchas predominantemente fragmentadas. Nota-se }\end{array}$ & Areia \\
escurecimento da areia em direção ao topo. & \\
\hline
\end{tabular}



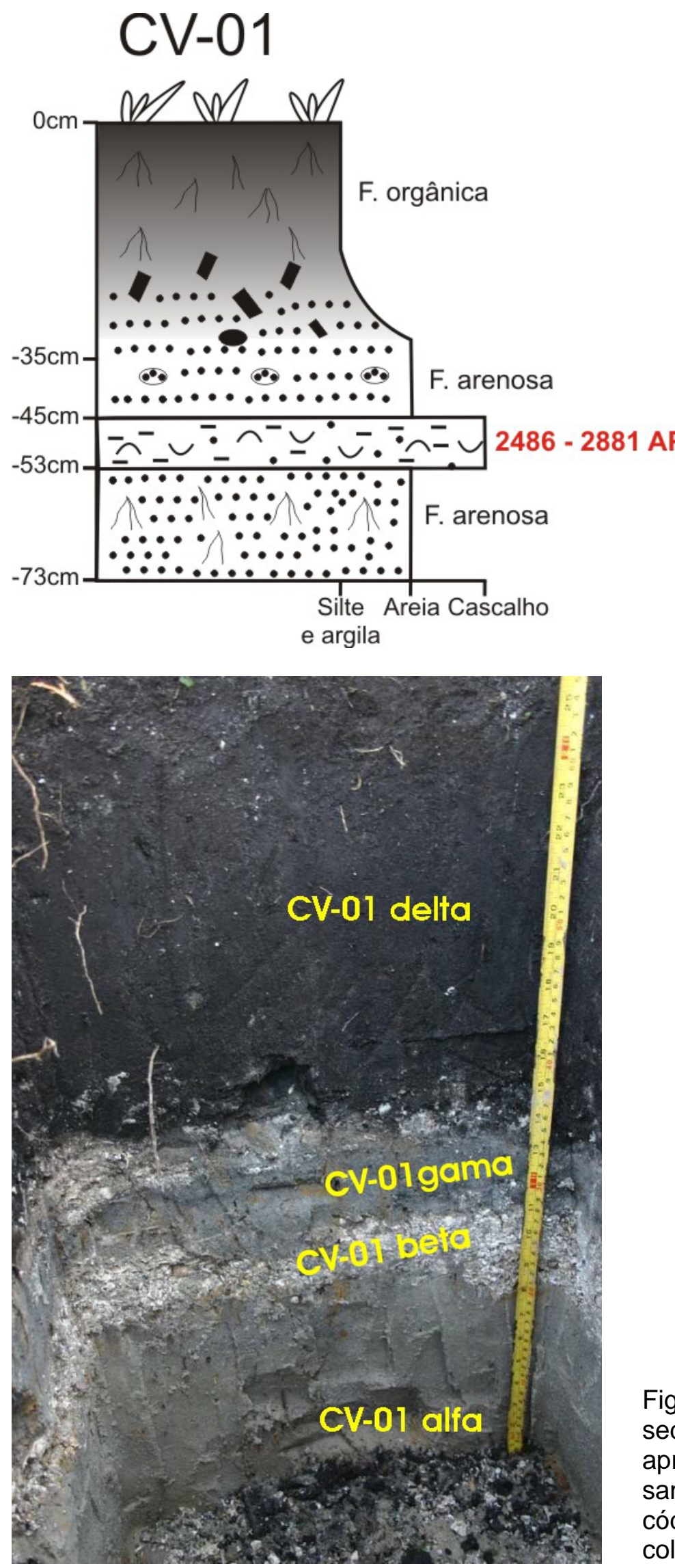

Figura 49 - Seção colunar em trincheira (CV-01), aproximadamente $10 \mathrm{~m}$ a SW do sambaqui Carniça I.
Figura 50 - Trincheira (CV-01) em sedimentos geogênicos, aproximadamente $10 \mathrm{~m}$ a SW do sambaqui Carniça I. Em amarelo, os códigos referentes às amostras coletadas. 


\subsection{Determinação dos teores de carbonato, fosfato e matéria orgânica total}

\subsubsection{Jabuticabeira}

No sítio Jabuticabeira II, os teores médios de carbonatos e fosfatos são maiores no sambaqui (49,5\% para fácies de "terra preta" e "funerária" e 60,3\% para as fácies conchíferas) que nos sedimentos geogênicos locais (3,5\%, Figura 51A). Esta diferença devese provavelmente ao acúmulo de conchas e ossos de peixe nas fácies analisadas do sambaqui. Também são maiores no sambaqui, de acordo com a mesma figura, as amplitudes de variação dos teores.

Em relação ao conteúdo de matéria orgânica (Figura 51B), nota-se semelhança entre sedimentos geogênicos e antropogênicos quanto aos valores médios (4,6\% para as fácies de "terra preta" e "funerária", 3,4\% para as fácies conchíferas e 3,0\% para os sedimentos geogênicos paleolagunares vizinhos), com sobreposição do intervalo interquartis, apesar de amplitude de variação ligeiramente maior nos sedimentos geogênicos (Jab Geo). Esta maior amplitude pode ser atribuída ao contraste entre as duas fácies encontradas nos sedimentos geogênicos, onde a fácies areno-lamosa (JB-01 $\beta$, JB-02 $\beta$, JB-03 $\beta$, JB-04 $\beta$ e JB-05 $\beta$, da Figura 35 a Figura 43) possui alta concentração de matéria orgânica coloidal quando comparada à fácies arenosa sotoposta.

Nas lâminas "funerárias" e "terra preta" do Jabuticabeira II, a quantidade discretamente maior de matéria orgânica em relação à de sedimentos geogênicos (Jab Geo) e de fácies conchífera (Jab concha, Boxplot de matéria orgânica total) pode relacionar-se ao acúmulo de carvão, observado em campo. Expresso em porcentagem em massa, este carvão é pouco representativo em virtude de sua baixa densidade.

A semelhança nos teores de matéria orgânica entre os sedimentos geogênicos e os antropogênicos não é suficiente para indicar mesma origem desta matéria orgânica, sendo que para isso é necessária a utilização de medidas isotópicas, abordadas no item 5.8 . 

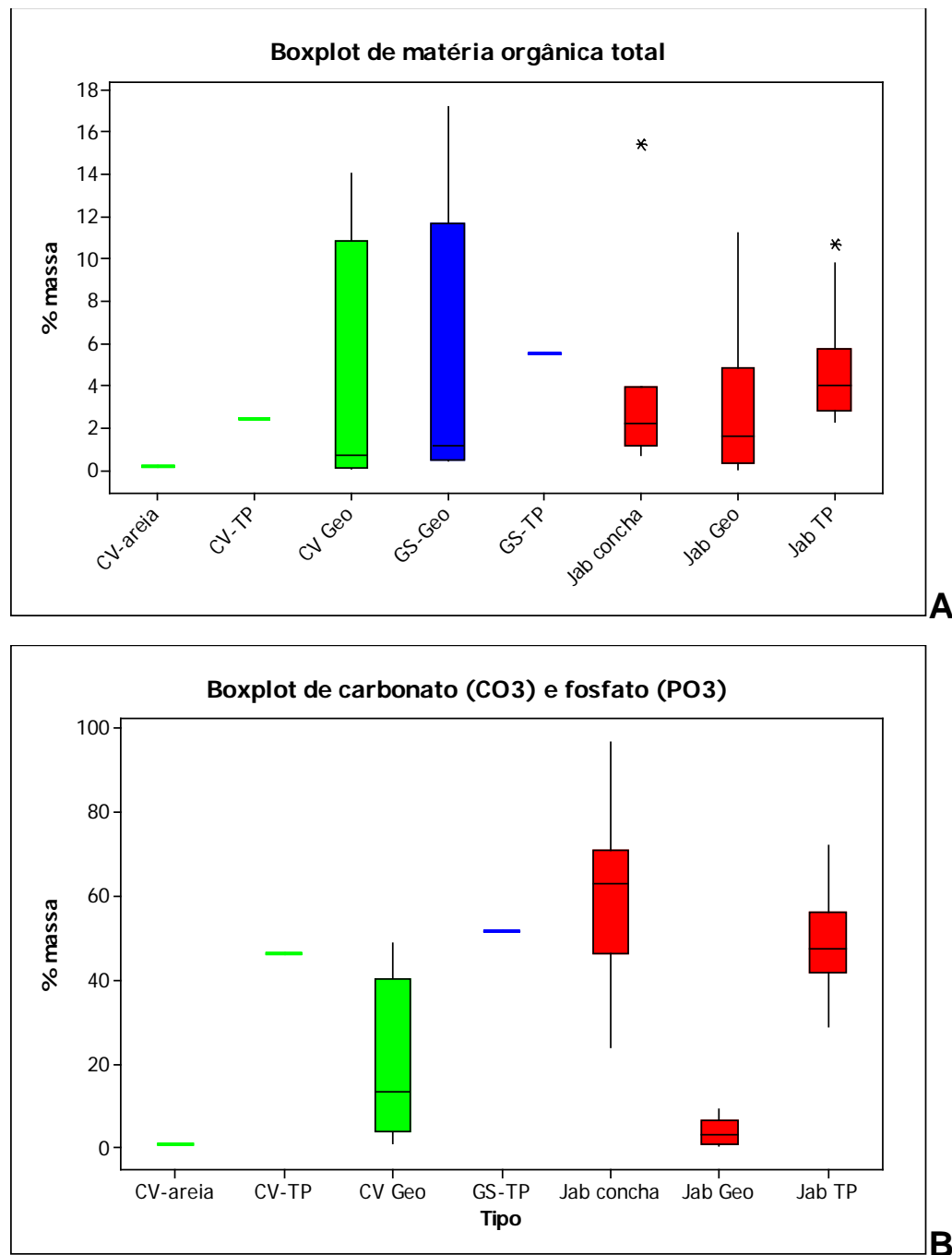

Figura 51 - Gráficos tipo boxplot das quantidades de matéria orgânica total e teor de carbonatos. As cores representam localidades. Geo - sedimento geogênico, oriundo de trincheira e poços. TP - "terra preta" e "funerária", oriundo de camada e lâminas carbonosas de sambaqui. Areia - sedimento de camada predominantemente arenosa de sambaqui. Concha - sedimento bioclástico de sambaqui.

\subsubsection{Campos Verdes}

A quantidade de carbonato e fosfato da fácies "terra preta" do sambaqui Carniça III (CV-TP) alcança valor equivalente ao bigode superior dos sedimentos geogênicos regionais (CV-01), o que denota o enriquecimento desta fácies em carbonato e/ou fosfato, em relação aos sedimentos naturais.

A fácies "terra preta" do Carniça III (CV-TP) registra quantidade de matéria orgânica inferior a pouco menos da metade da encontrada nos sedimentos geogênicos adjacentes (CV-01, Figura 51B). Vale ressaltar que esta situação é diferente da observada no sítio Jabuticabeira II. 


\subsection{Análise granulométrica}

\subsubsection{Jabuticabeira - distribuição das classes de areia}

Conforme se pode observar na Figura 52, a classe granulométrica areia fina predomina tanto nos sedimentos geogênicos eólicos (Eólicos Jab Giannini G2) e paleolagunares (Jab Geo), como nos extraídos do sambaqui Jabuticabeira II (Jab concha e Jab TP). Existe, entretanto, maior concentração da classe areia fina nos sedimentos geogênicos, se comparados aos sedimentos do sambaqui, onde a classe areia média é melhor representada. 


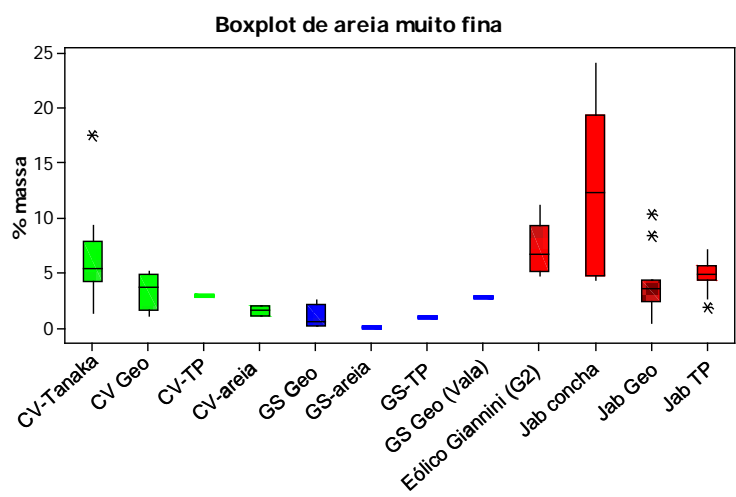

A

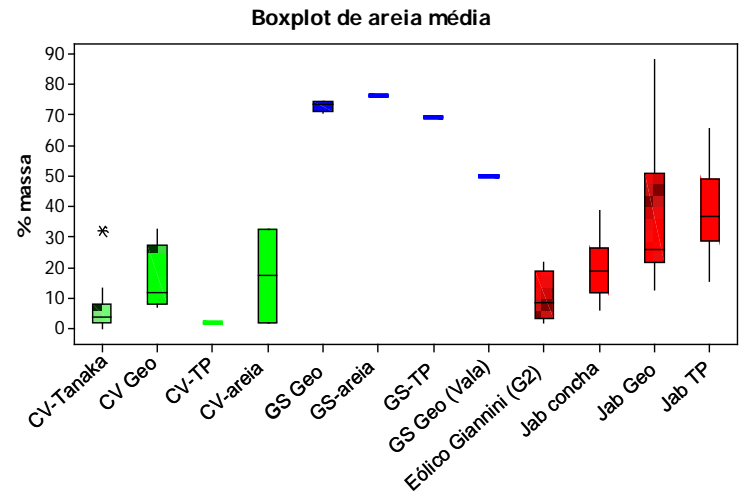

C

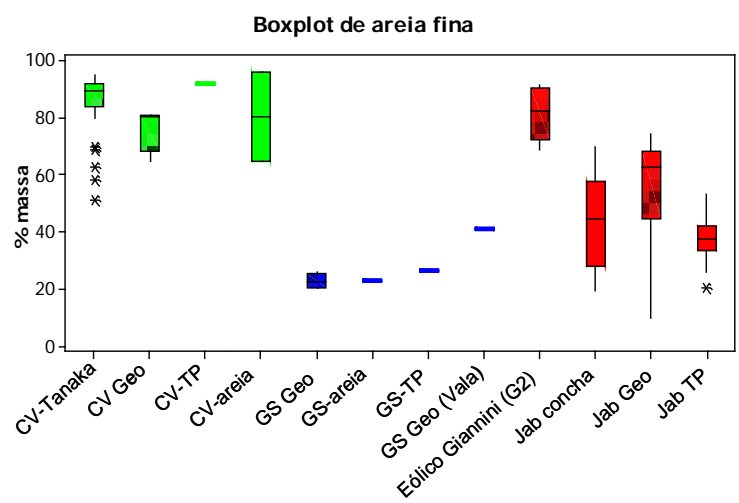

B

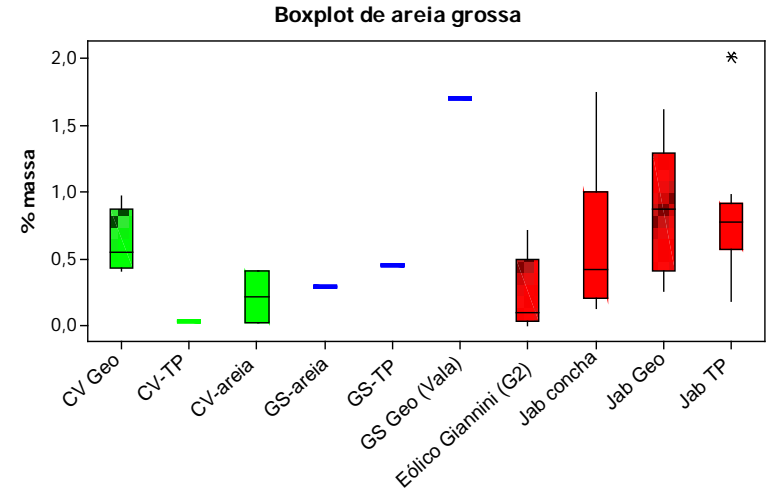

D

Figura 52 - Gráficos tipo boxplot das frações de areia. As cores representam localidades. Geo - sedimento geogênico, oriundo de trincheira e poços. TP - "terra preta" e "funerária", oriundo de camada e lâminas carbonosas de sambaqui. Areia - sedimento de camada predominantemente arenosa de sambaqui. Concha - sedimento bioclástico de sambaqui.

$\mathrm{Na}$ Figura 52A, nota-se similaridade entre as quantidades de areia muito fina em sedimentos eólicos da geração 2 (Eolicos Jab Giannini G2; Giannini, 1993) e nas fácies conchíferas do sambaqui (Jab concha). Observa-se, também, afinidade na distribuição das quantidades de areia muito fina entre as fácies "funerárias" e "terra preta" do sambaqui e os sedimentos paleolagunares próximos. Esta variável apresenta pouca amplitude de variação nos dois casos, com médias muito semelhantes entre si: 4,82\% (Jab TP) e 4,15\% (Jab Geo).

\subsubsection{Garopaba do Sul - distribuição das classes de areia}

Os sedimentos do sambaqui Encantada III (GS-areia e GS-TP) e dos depósitos geogênicos próximos (GS Geo) concentram-se na classe areia média, porém com quantidades relevantes de areia fina (20 a 40\%) e areia grossa (0,3 a 4,5\%) (Figura 52). As quantidades de areia grossa para os sedimentos geogênicos locais (GS Geo) podem ser 
atribuídas à presença de fragmentos bioclásticos, pois se trata de amostras não tratadas com $\mathrm{HCl}$ para retirada de carbonatos (as amostras da trincheira GS-03, referente a parte dos dados apresentados em GS Geo, foram obtidas e analisadas pela doutoranda Milene Fornari, sem tratamento ácido prévio).

\subsubsection{Campos Verdes - distribuição das classes de areia}

Os sedimentos dos sambaquis Carniça III e do substrato sedimentar do entorno possuem moda na fração areia fina (Figura 52B - caixas verdes), com quantidades apreciáveis (até cerca de 30\%) de areia média, principalmente na fácies arenosa do sambaqui (CV-areia) e nos sedimentos geogênicos (CV-01), ambos com medianas acima de $10 \%$ nesta última fração.

\subsubsection{Geral - distribuição das classes de areia}

A comparação entre os vários diagramas de caixa da Figura 52 permite inferir um controle sobretudo local sobre a distribuição das diferentes frações de areia, em detrimento da influência do tipo genético de sedimento (geogênico versus de sambaquis). Este controle pode ser melhor percebido nos boxplots de areia fina e areia média, frações preponderantes nas amostras coletadas.

\subsubsection{Jabuticabeira - parâmetros estatísticos}

Os sedimentos da região do sambaqui Jabuticabeira II (inclusive) possuem diâmetro médio entre 2,0 e 2,5 Ф (areia fina), sendo os sedimentos eólicos locais (Eólicos Jab Giannini G2) mais finos que os lagunares (Jab Geo) e os sedimentos das fácies conchíferas do sambaqui (Jab concha) mais finos que os das fácies "funerárias" e "terra preta" (Jab TP, Figura 53A).

No boxplot de desvio padrão da distribuição granulométrica (Figura 53B), nota-se pior seleção (maior desvio padrão) dos sedimentos oriundos do sambaqui em relação aos sedimentos geogênicos.

Os sedimentos geogênicos apresentam tendência para assimetria negativa e os do sambaqui para assimetria positiva (Figura 52C). Os sedimentos eólicos da geração 2 (Eólicos Jab Giannini G2) possuem assimetria notadamente mais negativa que os demais sedimentos desta localidade em geral. Considerando distribuição granulométrica unimodal, a 
assimetria negativa aponta cauda prolongada para o lado dos mais grossos e a positiva, cauda voltada para o lado dos mais finos.

\subsubsection{Garopaba do Sul - parâmetros estatísticos}

Os sedimentos do sambaqui Encantada III (GS-areia e GS-TP) e seu entorno (GS Geo) possuem o diâmetro médio mais grosso (entre 1,5 e $2 థ 0$ areia nédia) entre as amostras estudadas. Com base no desvio padrão (Figura 53B), nota-se que os sedimentos geogênicos (GS Geo) são menos selecionados que os sedimentos do sambaqui (GS-areia e GS-TP). Esta situação é oposta à encontrada na região de Jabuticabeira.

O boxplot de assimetria (Figura 53C) revelou que as amostras do Encantada III e entorno apresentam valores positivos para este parâmetro, ou seja, cauda da distribuição granulométrica voltada para a parte fina da distribuição. Este comportamento é discrepante das demais localidades estudadas, onde há valores de assimetria tanto positivos como negativos.

\subsubsection{Campos Verdes - parâmetros estatísticos}

Os sedimentos da localidade de Campos Verdes (CV) possuem diâmetro médio em torno de 2,5 Ф (areia fina), sendo discreta a difereça entre os grupos de amostras ( Figura 53A). Já com base no desvio padrão (Figura 53B), observa-se pior grau de seleção nos sedimentos geogênicos locais (CV-01 Geo), em comparação com os sedimentos do sambaqui Carniça III (CV-TP e CV-areia). Esta situação é a mesma registrada na localidade de Garopaba do Sul.

A assimetria da distribuição granulométrica é mais negativa para os sedimentos geogênicos e positiva para os sedimentos do sambaqui (Figura 53C), situação semelhante à observada para a localidade de Jabuticabeira. 


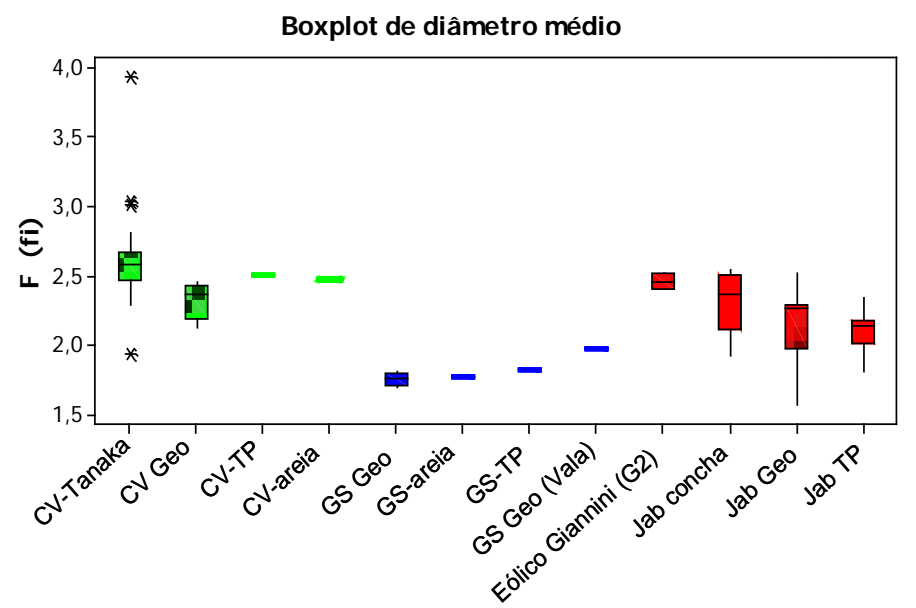

A

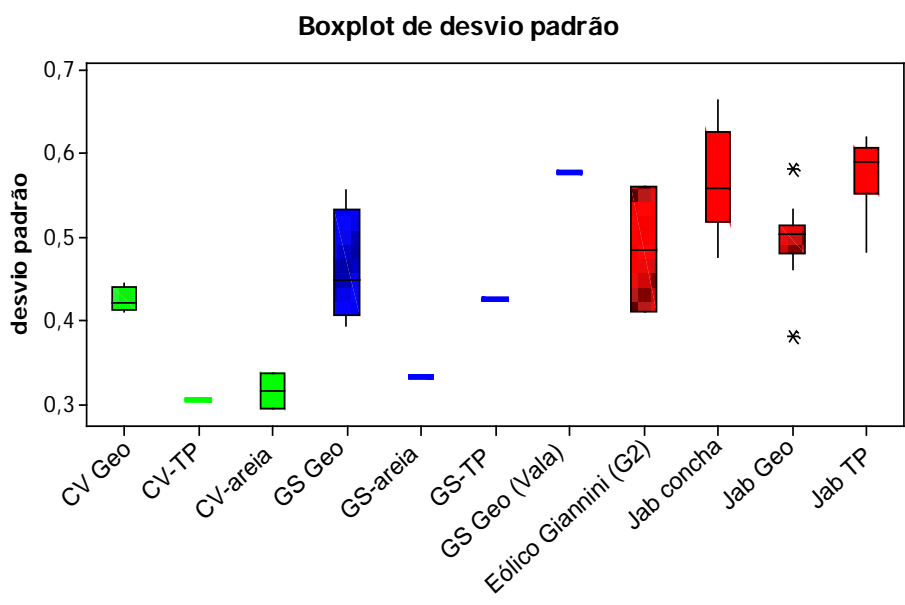

Figura 53 - Gráficos tipo boxplot dos parâmetros estatísticos da granulometria. As cores representam localidades. Geo sedimento geogênico, oriundo de trincheira e poços. TP - "terra preta" e "funerárias", oriundo de camada e lâminas carbonosas de sambaqui. Areia - sedimento de camada predominantemente arenosa de sambaqui. Concha sedimento bioclástico de

B sambaqui.

Boxplot de assimetria

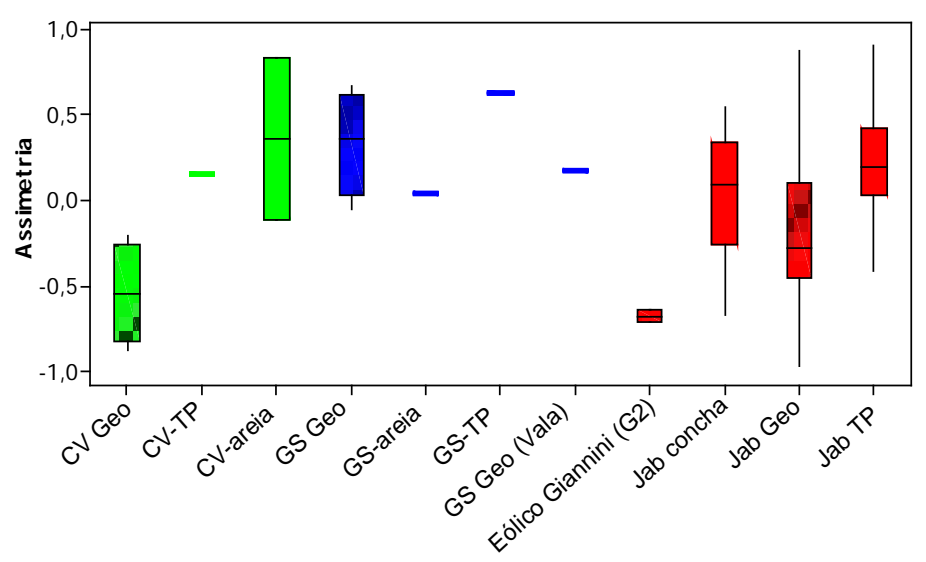

C 


\subsubsection{Diagramas de dispersão de parâmetros estatísticos da granulometria}

Nos diagramas binários de dispersão de parâmetros estatísticos da distribuição de freqüências granulométricas (diâmetro médio, desvio padrão e assimetria) relativos à região do sítio Jabuticabeira II (Figura 54 e Figura 55), evidencia-se grande semelhança entre sedimentos do sambaqui e da paleolaguna. Já os sedimentos eólicos, principalmente os da geração 3, diferenciam-se dos demais pelo maior grau de seleção e pelo diâmetro médio mais fino (Figura 54).

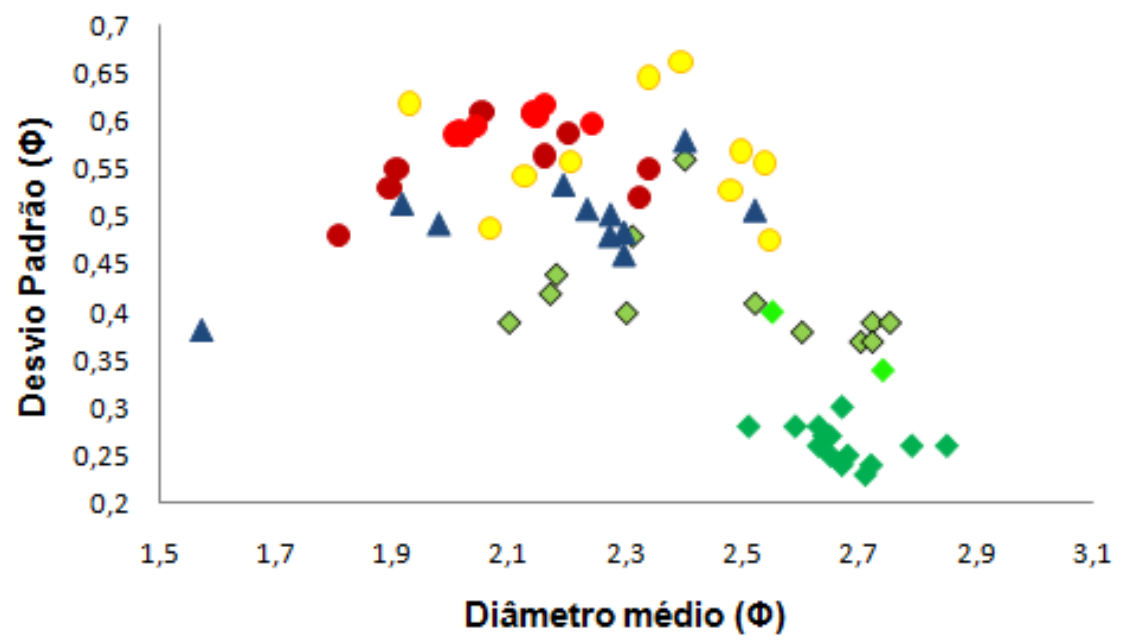

$\bullet$ Dunas G1

$\diamond$ Dunas G2

- Dunas G3

Jabuticabeira II - concha

- Jabuticabeira II - F. LC

- Jabuticabeira II - F. LA

A Paleolaguna

Figura 54 - Diagrama de dispersão dos parâmetros granulométricos diâmetro médio e desvio padrão para amostras da região do sítio Jabuticabeira II. Os dados referentes às dunas eólicas de diferentes gerações (G1, G2 e G3) foram retirados de Giannini (1993), com as seguintes áreas de abrangência: G1 - entre rio Riachinho e rio Sangão; G2 - entre a lagoa do Figueirinha e a margem sudoeste da laguna Garopaba do Sul; G3 - entre as ponta da Galheta e da Ilhota. Isto está muito estranho. 


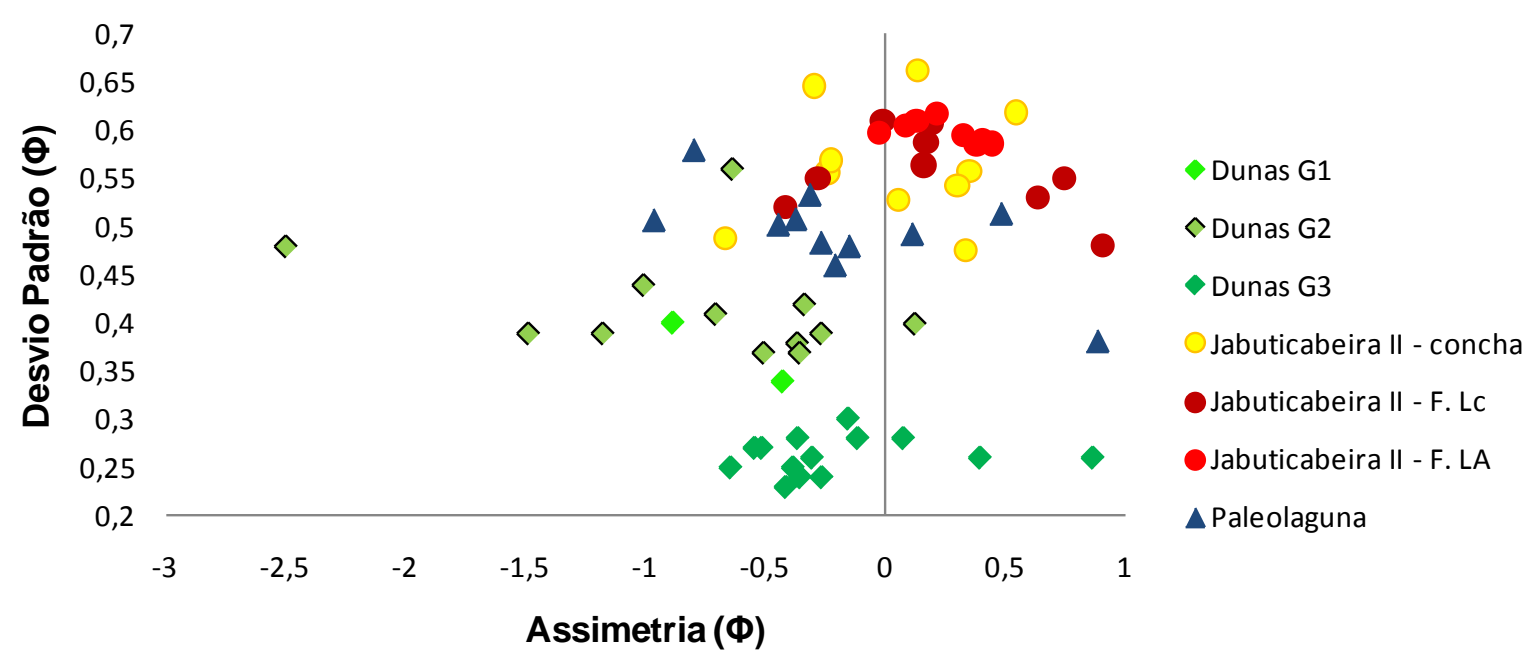

Figura 55 - Diagrama de dispersão dos parâmetros granulométricos assimetria e desvio padrão para amostras da região do Jabuticabeira II. Os dados referentes as dunas eólicas de diferentes gerações (G1, G2 e G3) foram retiradas de Giannini (1993), onde G1 - entre rio Riachinho e rio Sangão; G2 - entre a lagoa do Figueirinha e a margem sudoeste da laguna Garopaba do Sul; G3 - entre a ponta da Galheta e ponta da Ilhota.

Diagramas de dispersão similares, construídos para os sedimentos relacionados aos outros dois sambaquis em estudo (Figura 56 e Figura 57), indicam afinidade entre depósito arqueológico e depósito paleolagunar local também para o sambaqui Encantada III, especialmente quanto a diâmetro médio e assimetria. Já a fácies arenosa do mesmo sambaqui, no diagrama de assimetria versus desvio padrão (Figura 57), aproxima-se também dos sedimentos eólicos da geração 3.

A maior afinidade granulométrica dos sedimentos do sambaqui Carniça III dá-se com sedimentos de cordões litorâneos lagunares da região de Campos Verdes e dunas da geração 3 superimpostas, e não com sedimentos da paleolaguna Santa Marta (Carniça I, Figura 56 e Figura 57). 


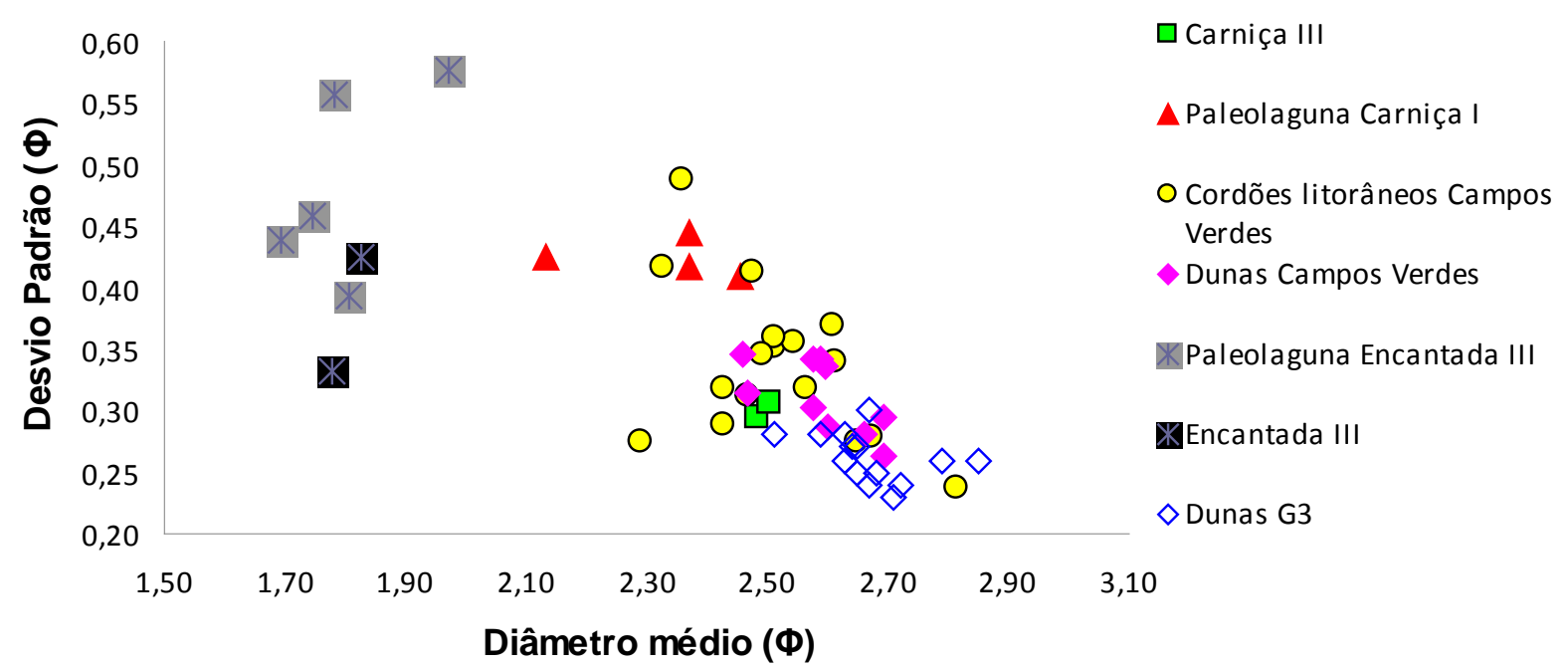

Figura 56 - Diagrama de dispersão dos parâmetros granulométricos diâmetro médio e desvio padrão para amostras da região dos sítios Carniça III e Encantada III. Os dados referentes as dunas eólicas da geração 3 (G3) foram retirados de Giannini (1993), relativos à região compreendida entre as pontas da Galheta e da Ilhota. Os dados referentes a cordões litorâneos e dunas eólicas de Campos Verdes foram extraídos de Tanaka (2007).

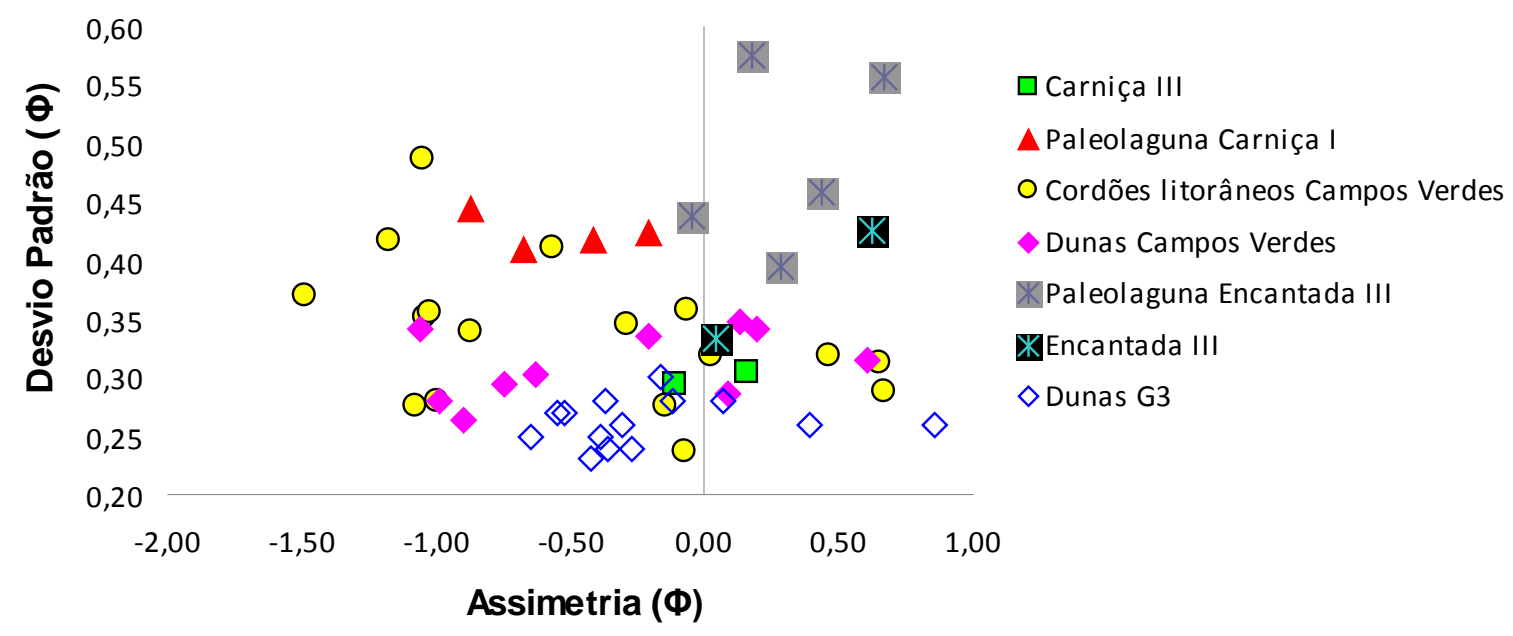

Figura 57 - Diagrama de dispersão dos parâmetros granulométricos desvio padrão e assimetria, para amostras da região dos sítios Carniça III e Encantada III. Os dados referentes as dunas eólicas da geração 3 (G3) foram retirados de Giannini (1993), relativos à região compreendida entre as pontas da Galheta e da Ilhota. Os dados referentes a cordões litorâneos e dunas eólicas de Campos Verdes foram extraídos de Tanaka (2007). 


\subsection{Mineralogia de pesados}

Dentre os minerais pesados transparentes, nenhum apresentou freqüência de ocorrência por lâmina maior que 60\%. O zircão varia de 17\% a 58\% no grupo de amostras referente ao sambaqui Jabuticabeira II e entorno, entre $11 \%$ e $41 \%$ no grupo relativo ao sambaqui Carniça III, e entre $19 \%$ e $40 \%$ no grupo do sítio Encantada III. Os minerais pesados que se mais destacam em seguida, em quantidade, são: turmalina, com abundância média em torno de 15\%; estaurolita, com 12\%; e rutilo, em torno de $7 \%$. A fácies arenosa do sambaqui Encantada III (Encantada areia, Tabela 11) destoa das demais por apresentar as maiores freqüências de granada (15\%) e turmalina (25\%) e a menor de cianita (1\%).

Os minerais polimorfos de $\mathrm{Al}_{2} \mathrm{SiO}_{5}$, cianita, sillimanita e andaluzita, contribuem, em grande parte das fácies, com até $8 \%$ (0-8\%). A fácies conchífera (L) do sambaqui Jabuticabeira II apresenta a freqüência mais elevada de sillimanita (8\%) e os sedimentos geogênicos e de sambaqui da região de Campos Verdes apresentam as maiores concentrações de cianita (de 5 a 8\%).

As maiores concentrações de alterita encontram-se na fácies "terra preta" do sambaqui Encantada III e nos sedimentos geogênicos próximos ao sambaqui Carniça I (paleolaguna Santa Marta), com média de 5,7\% e 6,6\%, respectivamente. Para as demais áreas estudadas, este componente possui abundância da ordem de 2,5\%. Os minerais hiperstênio, clinozoisita/zoisita, apatita, hastingsita, monazita, espinélio, anatásio, augita, allanita, titanita e clinoanfibólio incolor possuem freqüências de ocorrência por amostra menores que 3\%.

Os sedimentos geogênicos e de sambaqui da região de Jabuticabeira apresentam maior maturidade mineralógica (iZTR) que os de demais localidades de amostragem (Figura 58A), sem mostrar diferenças notáveis entre si. Já os depósitos da região de Campos Verdes (Carniça III e depósitos geogênicos do entorno) apresentam os valores de iZTR mais baixos. Confirmando esta tendência, os mais altos índices de minerais instáveis (ilNS, Figura 58C) encontram-se nas amostras do Carniça III (CV-areia, CV-TP e CRN-02 areia) e nos depósitos geogênicos da área próxima a este sambaqui (Campos Verdes e CV-01 Geo).

Em relação ao índice de minerais metaestáveis (iMET, Figura 58B), os sedimentos da região do sítio Jabuticabeira II (geogênicos e antropogênicos, pouco diferentes entre si) possuem menores valores em relação aos do Carniça e Encantada III. Os valores mais elevados de minerais metaestáveis nestes dois últimos devem-se, principalmente, às proporções relativamente altas de epídoto e granada. 


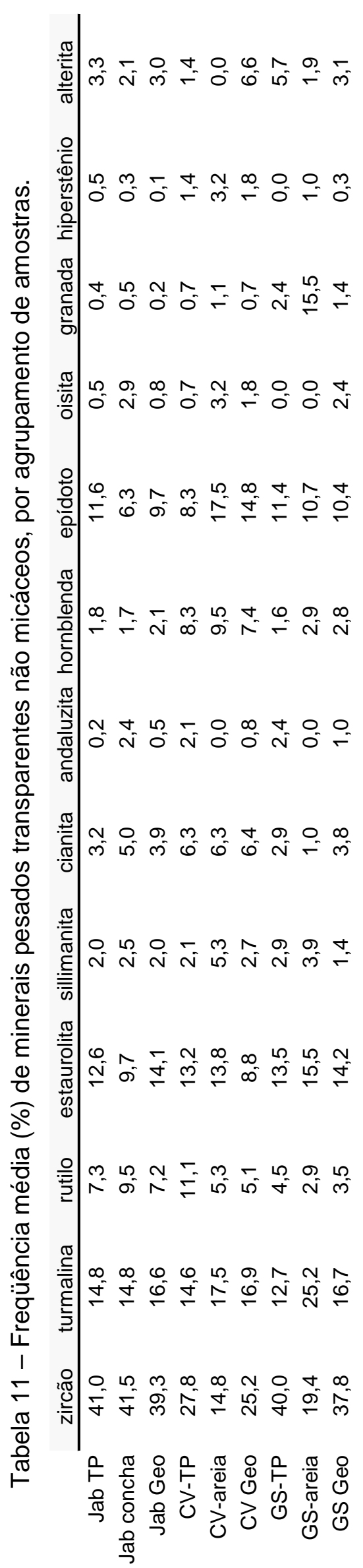



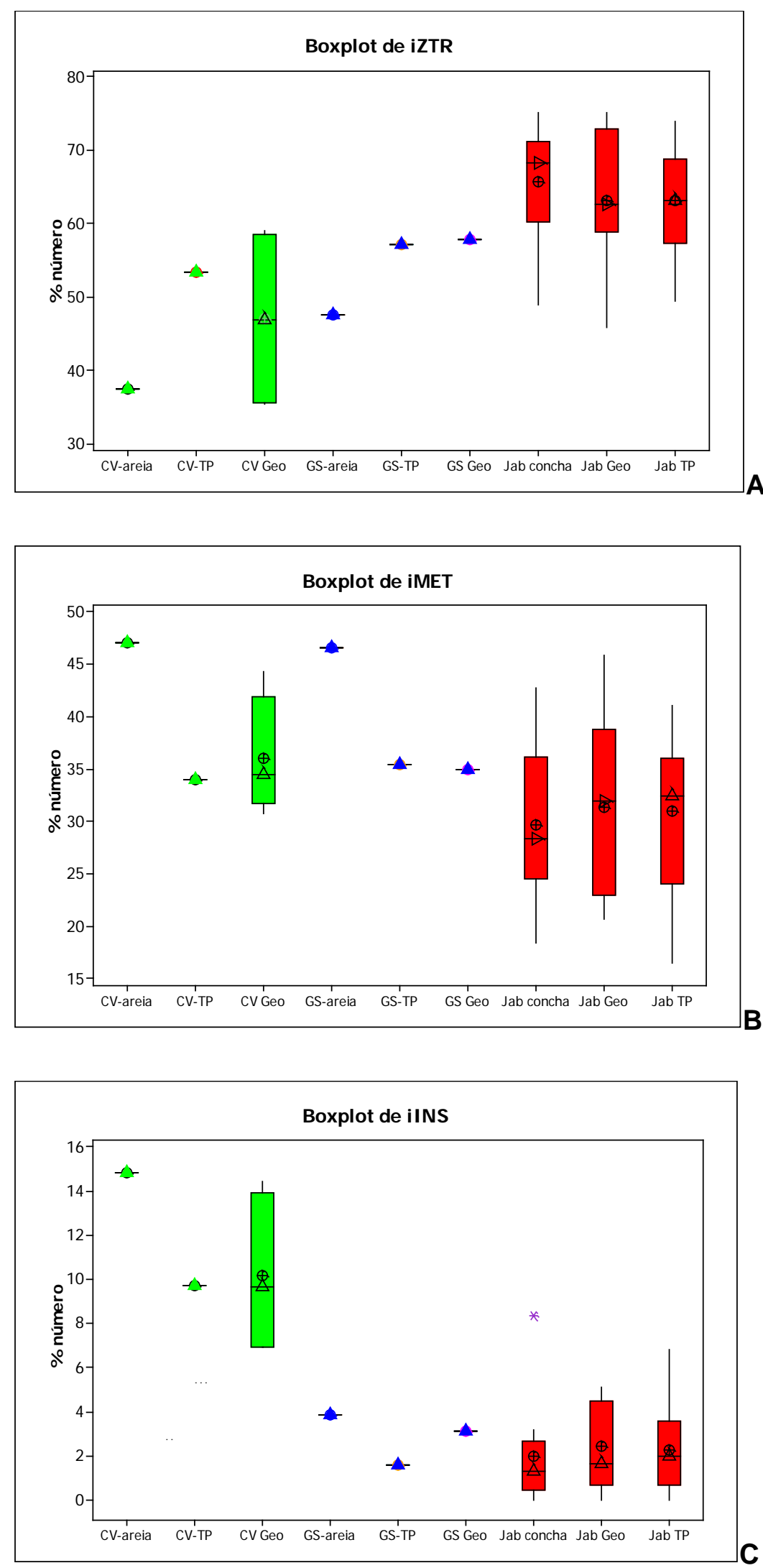

Figura 58 - Gráficos tipo boxplot dos índices de estabilidade química de minerais pesados. iZTR: soma das porcentagens de minerais ultraestáveis; iMET: soma das porcentagens de minerais metaestáveis e iINS: soma das porcentagens de minerais instáveis. As cores representam localidades. Geo - sedimento geogênico, oriundo de trincheira $\mathrm{e}$ poços. TP - "terra preta" e "funerárias", oriundo de camada e lâminas carbonosas de sambaqui. Areia - sedimento de camada predominantemente arenosa de sambaqui. Concha - sedimento bioclástico de sambaqui. 


\subsection{Análise da fração grossa sob lupa estereoscópica}

De modo a simplificar a apresentação dos resultados, os tipos de grãos identificados em lupa foram agrupados, segundo critérios de afinidade descritiva, em seis categorias: fragmentos siliciclásticos, bioclastos inteiros, bioclastos fragmentados, produtos de combustão, fragmentos fosfáticos e ossos marrons (Tabela 12).

Tabela 12 - Tipos de grãos identificados sob lupa binocular e agrupados por afinidade descritiva de textura e/ou constituição.

\begin{tabular}{|c|c|c|}
\hline Grupo & Componentes & Interpretação e/ou descrição \\
\hline Fragmentos siliciclásticos & $\begin{array}{l}\text { Grãos de quartzo, feldspato } \\
\text { e outros minerais eventuais, } \\
\text { torrões de argila e lama } \\
\text { (agregados lamíticos) e } \\
\text { fragmentos de rocha }\end{array}$ & $\begin{array}{l}\text { Grãos de origem geogênica } \\
\text { essencialmente física }\end{array}$ \\
\hline Bioclastos inteiros & $\begin{array}{c}\text { Conchas de bivalves e } \\
\text { gastrópodes, com e sem } \\
\text { impregnações }\end{array}$ & $\begin{array}{l}\text { Conchas com pelo menos } \\
80 \% \text { de sua morfologia } \\
\text { preservada }\end{array}$ \\
\hline Bioclastos fragmentados & $\begin{array}{l}\text { Fragmentos de conchas de } \\
\text { bivalves e gastrópodes, com } \\
\text { e sem impregnações }\end{array}$ & $\begin{array}{c}\text { Conchas com mais de } 80 \% \\
\text { de sua morfologia } \\
\text { deteriorada }\end{array}$ \\
\hline Produtos de combustão & $\begin{array}{l}\text { Fragmentos de ossos em } \\
\text { diversos graus de alteração } \\
\text { térmica (marrom escuros, } \\
\text { pretos e brancos), conchas } \\
\text { acinzentadas (fragmentadas } \\
\text { e inteiras), carvão, agregado } \\
\text { de cinzas, escória vítrea e } \\
\text { sementes carbonizadas. }\end{array}$ & $\begin{array}{c}\text { Materiais alterados } \\
\text { termicamente } \\
\text { (aparentemente queimados) }\end{array}$ \\
\hline Crostas fosfáticas & $\begin{array}{l}\text { Incrustações marrom escuro } \\
\text { e claro, com ou sem textura } \\
\text { botrioidal, associados a } \\
\text { fragmentos de conchas e } \\
\text { ossos (revestimento), ou } \\
\text { isolados. }\end{array}$ & $\begin{array}{l}\text { Fragmentos crustiformes } \\
\text { compostos por fosfato } \\
\text { (identificado por microscopia } \\
\text { óptica e difração de raios X) }\end{array}$ \\
\hline Ossos marrons & $\begin{array}{l}\text { Fragmentos de ossos de } \\
\text { com marrom claro a bege }\end{array}$ & $\begin{array}{l}\text { Fragmentos de ossos que } \\
\text { aparentemente não foram } \\
\text { alterados termicamente }\end{array}$ \\
\hline
\end{tabular}


A presença e abundância dos componentes desses grupos variam de acordo com a fração estudada. Por exemplo, o grupo "fragmentos siliciclásticos", na fração 4mm, refere-se a torrões de lama e fragmento de rocha. Já na fração $0,5 \mathrm{~mm}$, esta mesma categoria abrange torrões de lama (cinza/branca ou vermelha), torrões de argilomineral verde, fragmentos de rocha, quartzo (arredondado ou subanguloso), feldspato e mica.

A fim de trabalhar com uma quantidade menor de dados sem perder a representatividade dos parâmetros analisados, os resultados referentes à quantificação sob lupa (em \% de fragmentos) de cada amostra foram ponderados pelo peso de cada fração granulométrica e, dessa forma, extraídas as médias por grupos de afinidade descritiva. Os resultados deste processamento encontram-se resumidamente expressos da Figura 62 a Figura 64, para o sambaqui Jabuticabeira II, na Figura 65, para os depósitos geogênicos do entorno do sambaqui Jabuticabeira II, na Figura 66, para a fácies "terra preta" do sambaqui Encantada III e os depósitos geogênicos do entorno, e na Figura 67, para a fácies "terra preta" do sambaqui Carniça III e sedimentos geogênicos do entorno do Carniça I.

Parte dos componentes identificados encontra-se ilustrada em fotomicrografias, da Figura 59 a Figura 61.

O gráfico de distribuição dos componentes por fácies no sambaqui Jabuticabeira II (Figura 62) evidencia acréscimo da quantidade de fragmentos siliciclásticos e produtos de combustão rumo ao topo, a apartir das fácies LA, conforme indicado pelas setas preta e vermelha, respectivamente. Nota-se também, na Figura 63 e na Figura 62, ausência de fragmentos fosfáticos em algumas fácies (CLb, $\mathrm{Cb}, \mathrm{Cl}$ e $\mathrm{Ap}$ ), mesmo quando adjacentes a fácies que possuam este tipo de componenente. Este fato constitui indício à hipótese de transporte mecânico destes fragmentos. 
a)

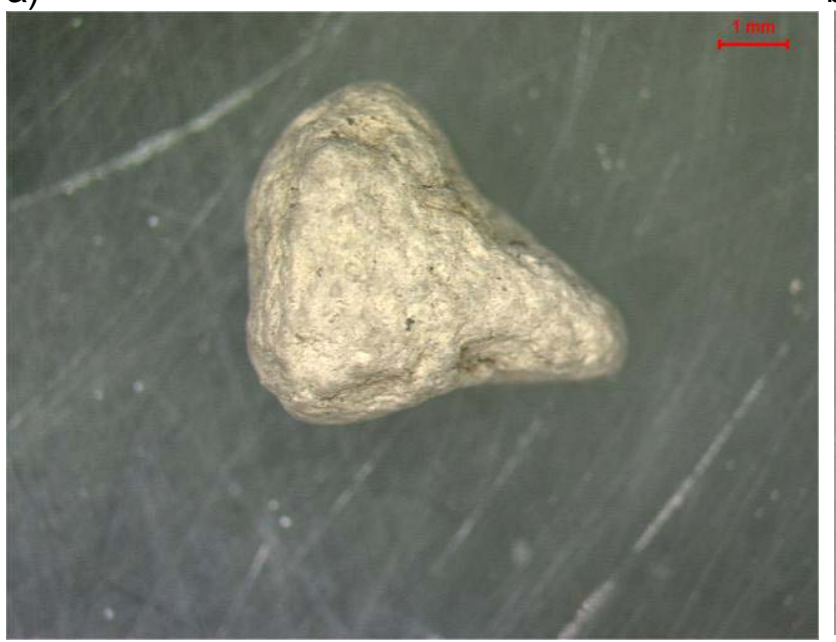

b)

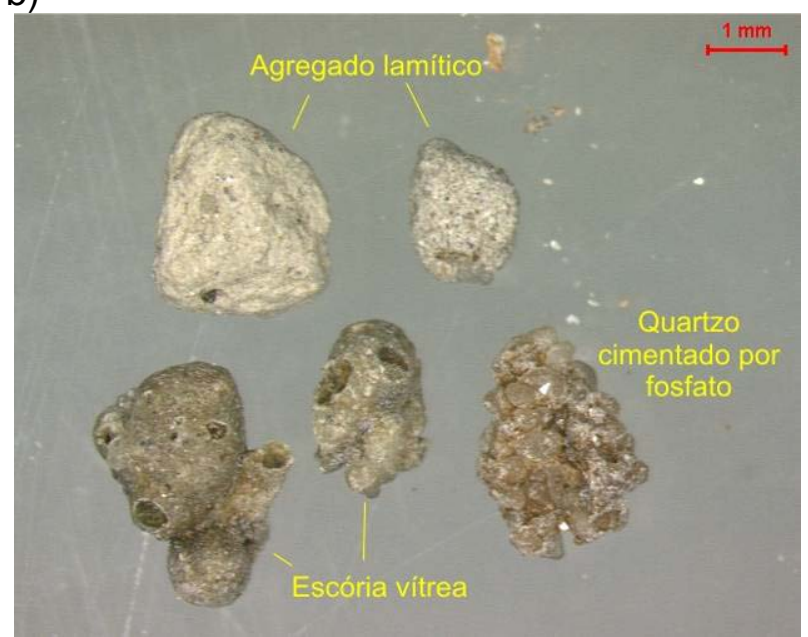

Figura 59 - Fotomicrografias de agregados lamíticos ricos em diatomáceas (a e b), componente do grupo "fragmentos siliciclásticos", de escória vítrea (b), componente do grupo "produtos de combustão", e de grãos de quartzo cimentados por fosfato (b), componente do grupo "crosta fosfática". Os agregados lamíticos com diatomáceas assemelham-se à fácies argilosa cinza clara, rica em diatomáceas descrita por Amaral (2009). Amostras JB-12-TP (a) e JB-02-TP (b)

a)

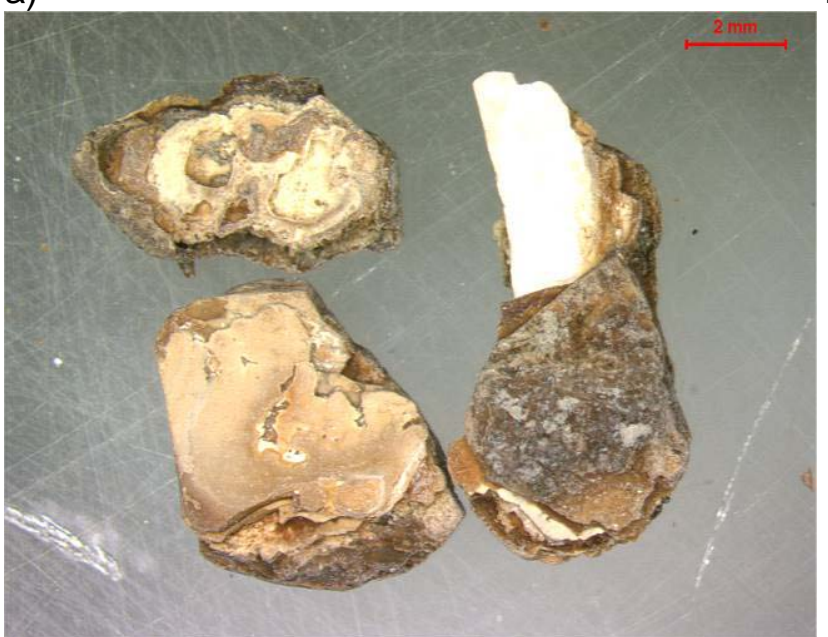

b)

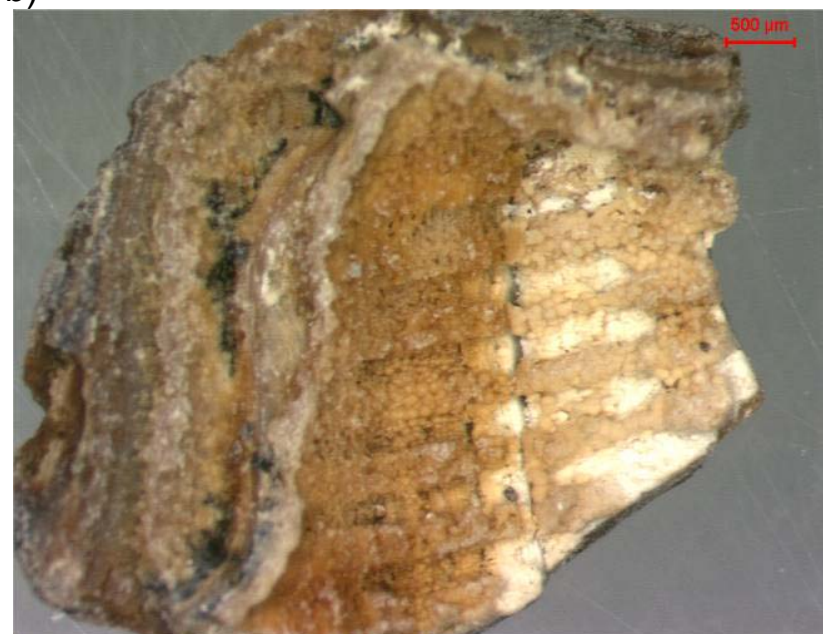

Figura 60 - Fotomicrografias de fragmentos de concha com incrustação fosfática (a e b), componente do grupo "crostas fosfáticas". Amostra JB-06-TP. 


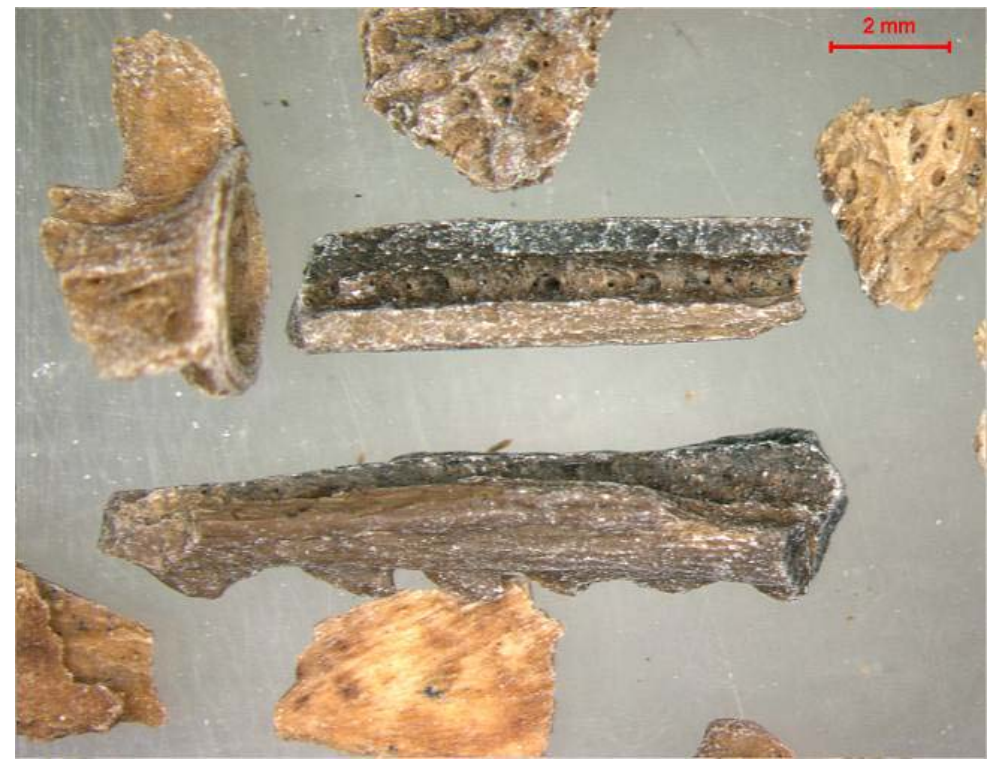

a)

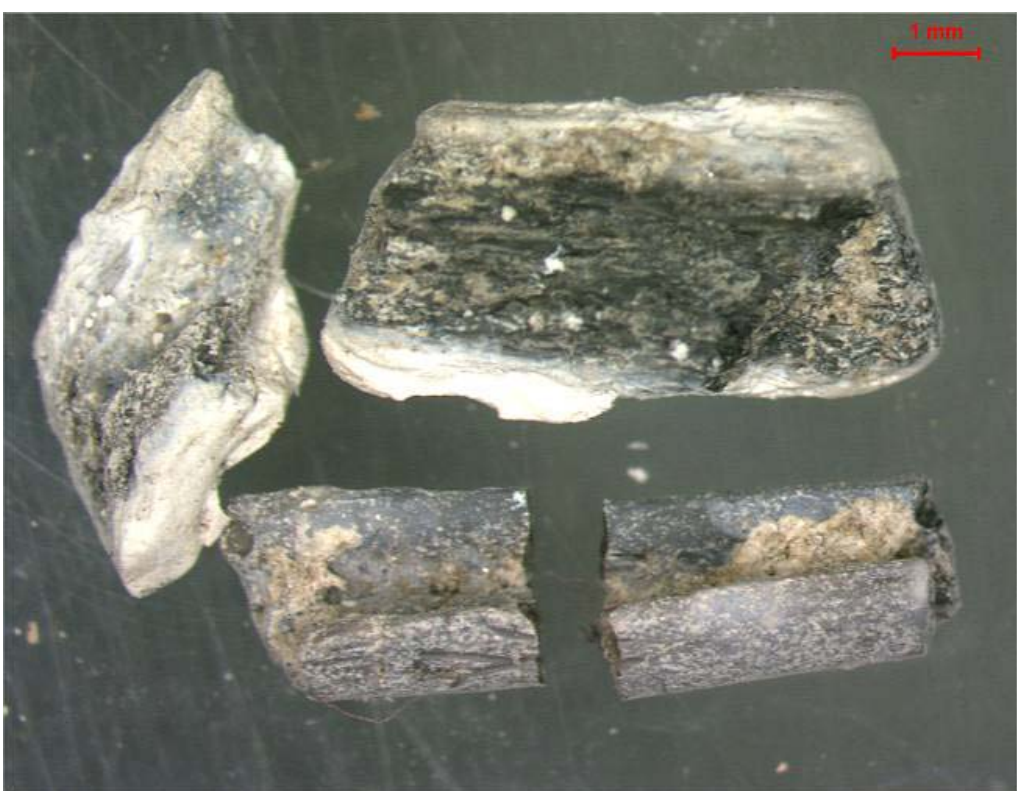

b)

Figura 61 - Fotomicrografias de ossos em diferentes graus de alteração térmica, do grupo "produtos de combustão". O fragmento do canto superior à direita (em a) foi considerado como "osso marrom" e, portanto, não alterado termicamente (a) e os de b, fragmentos de ossos calcinados. Amostras JB-01-TP (a) e JB-04-TP (b) 




Figura 62 - Distribuição em barra dos resultados da análise da fração grossa das amostras do lócus 1 do sambaqui Jabuticabeira II, representados pelos códigos de fácies e expressos em \% de cada grupo (cores da legenda). As setas indicam aumento ascendente da quantidade dos componentes "produtos de combustão" (seta vermelha) e "fragmentos siliciclásticos" (seta preta). Localização das amostras nas Figura 31 e Figura 32.

Ainda nas mesmas figuras, observa-se que no locus 1 a incidência de fácies que possuem fragmentos fosfáticos é maior que no lócus 2 , onde a ocorrência destes fragmentos torna-se quase nula, da amostra JB-04-TP para cima. Outro componente que parece ter sua incidência suprimida em algum momento são os bioclastos inteiros, cuja ocorrência no lócus 1 (Figura 62) está restrita às fácies estratigraficamente abaixo da LA, e em menor quantidade em comparação ao lócus 2 (Figura 63). A supressão de bioclastos na fácies LA não se restringe aos bioclastos inteiros, uma vez que os fragmentados também são praticamente eliminados da amostra JB-11-TP para cima (Figura 62). Diferentemente de bioclastos, de crostas fosfáticas e de fragmentos siliciclásticos, os fragmentos de ossos não alterados 
termicamente (ossos marrons) encontram-se distribuídos por toda a coluna, apenas com variações errantes em sua concentração.

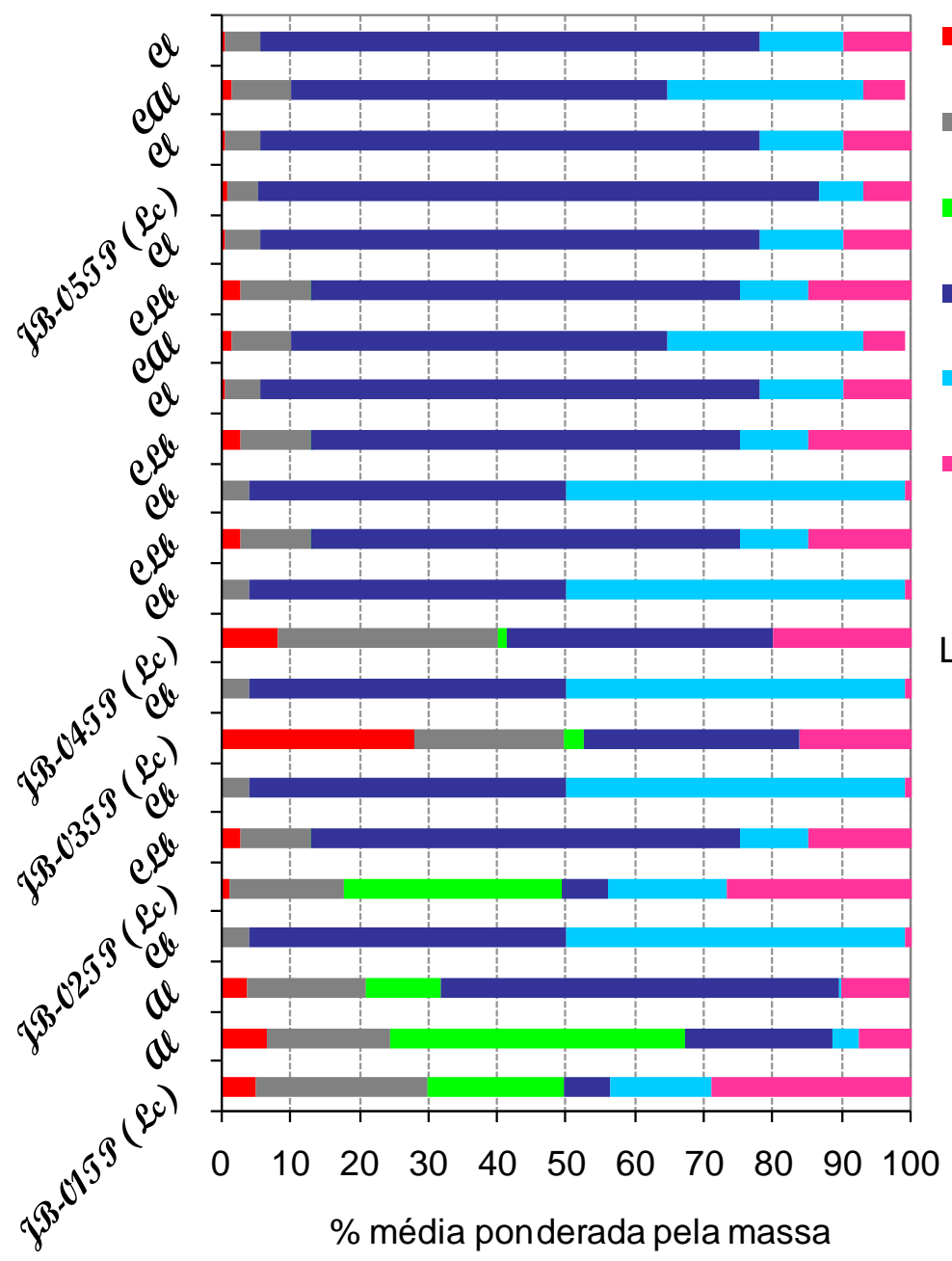

- produtos de combustão

usso marrom

- crostas fosfáticas (sobre ossos ou conchas, ou puras)

- bioclastos fragmentados

bioclastos inteiros

- fragmentos siliciclásticos

Locus 2 - Jabuticabeira II

Figura 63 - Distribuição em barra dos resultados da análise da fração grossa das amostras do lócus 2 do sambaqui Jabuticabeira II, representados pelos códigos de fácies e expressos em \% por grupo textutal-mineralógico (cores da legenda). Localização das amostras na Figura 34.

A partir da observação da distribuição global dos componentes da fração grossa (Figura 62 a Figura 64), notam-se três domínios de componentes, com ocorrência preferencial em determinadas fácies. O primeiro domínio, de fragmentos bioclásticos (inteiros e fragmentados), estende-se por todas as fácies abaixo da LA, compondo o também denominado "pacote conchífero" (DeBlasis et al, 2005; Bendazzoli, 2007); com maior expressão no lócus 2, este domínio ocorre em continuidade estratigráfica, passando de fácies para fácies sem grandes interrupções. O segundo domínio, das crostas fosfáticas, restringe-se às fácies mais ricas em matéria orgânica ( $A \ell$, Lc e $L A)$, ocorrendo com maior freqüência no locus 1 e na base do lócus 2. O terceiro domínio é o dos produtos de 
combustão, que, embora ocorram em quase todas as fácies, incidem com maior expressão (> 75\%) nas fácies lenticulares com pouca extensão lateral (L e CL $\ell$ - Figura 64). Este tipo de fácies foi descrito por Klökler (2002), Bendazzoli (2007), Villagrán (2008) e Klökler (2008) como "fogueiras antrópicas" e interpretado como materialização de processo combustivo in loco.

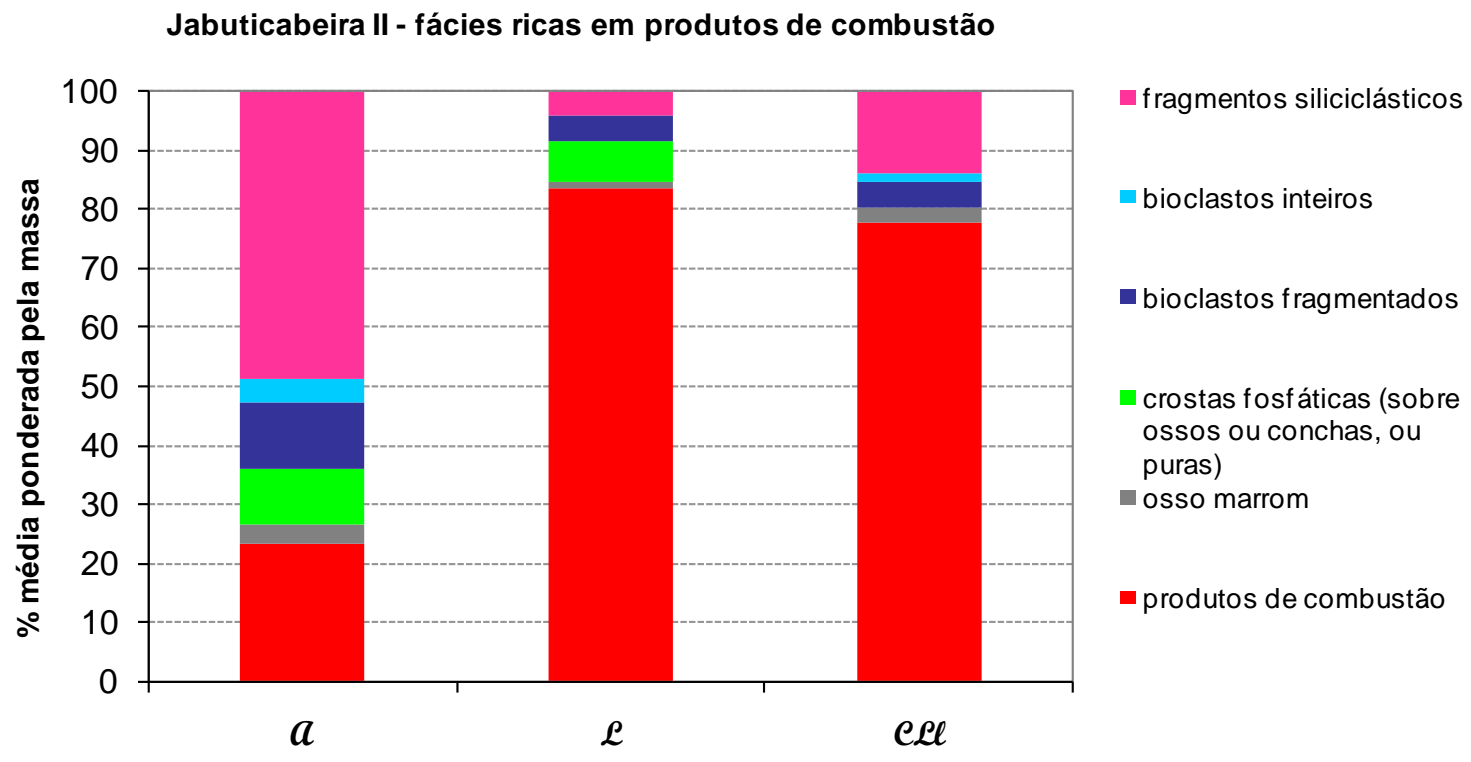

Figura 64 - Distribuição em coluna dos resultados da análise da fração grossa das amostras referente às fácies ricas em produtos de combustão do sambaqui Jabuticabeira II, expressos em \% por grupo textural-mineralógico (cores da legenda).

A distribuição dos componentes da fração grossa nos sedimentos geogênicos da área adjacente ao sambaqui Jabuticabeira II distingue-se do próprio sambaqui, conforme esperado, pela quantidade maior de fragmentos siliciclásticos (Figura 65). Apesar disso, os sedimentos geogênicos também incluem fragmentos de origem supostamente antropogênica, como produtos de combustão e ossos marrons. Ocorrem também quantidades pequenas (até 6\%) de fragmentos fosfáticos (Figura 65), que pode ser interpretada como transportada pelo homem do local de precipitação.

A origem destes materiais arqueológicos em meio aos sedimentos geogênicos está relacionada à proximidade com o sambaqui, visto que o ponto de amostragem mais distante do sítio (JB-04) não os contém (Figura 65). A presença destes materiais pode indicar remanejamento antrópico nas áreas do entorno do sambaqui, uma vez que, pela proximidade não tão imediata, pode-se, neste caso, descartar a hipótese de transporte geogênico por erosão. 


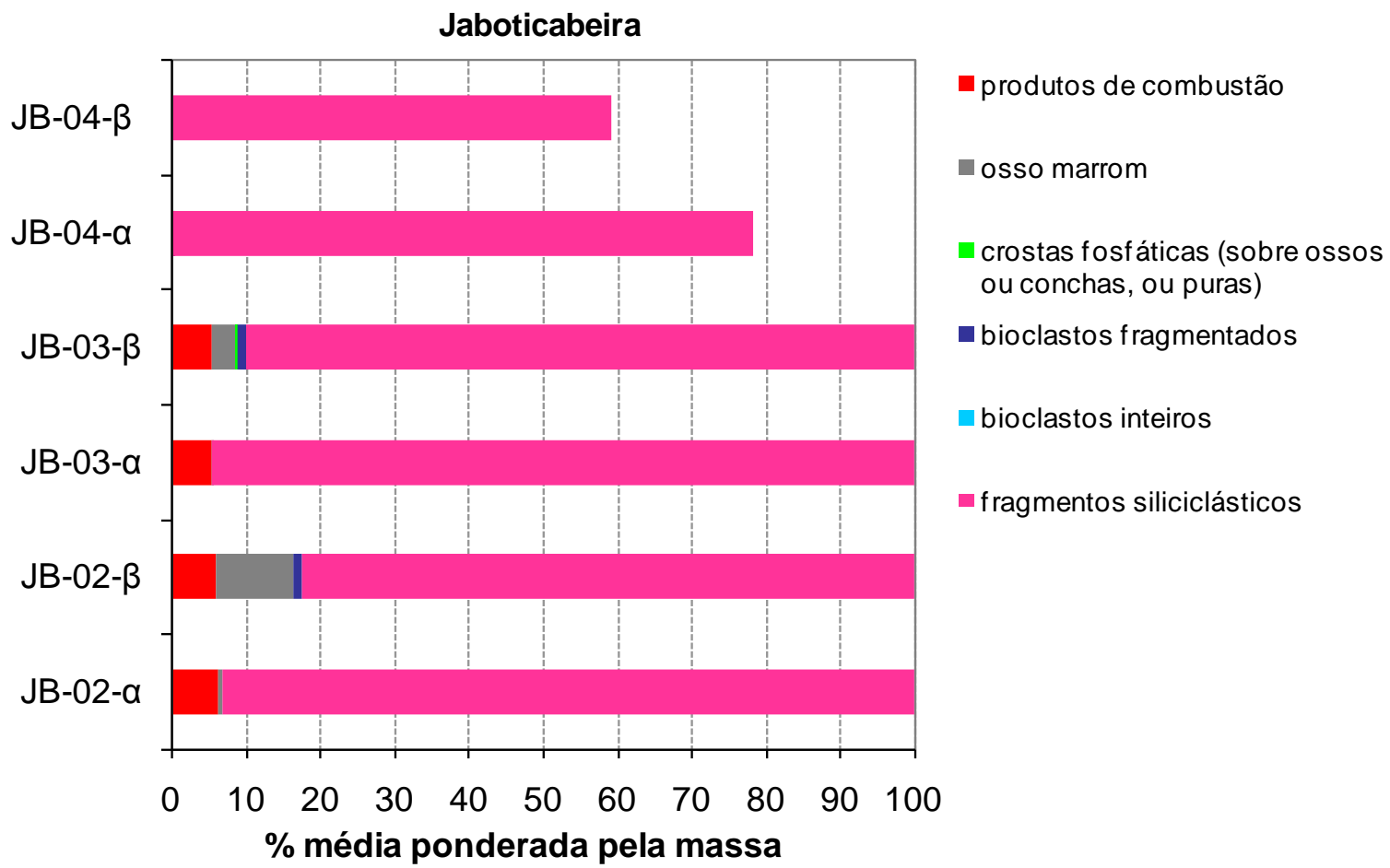

Figura 65 - Distribuição em barra dos resultados da análise da fração grossa das amostras dos sedimentos geogênicos do entorno do sambaqui Jabuticabeira II, representados pelos códigos de fácies e expressos em \% por grupo texturalmineralógico (cores da legenda). As amostras JB-04- $\alpha$ e $\beta$ possuem aproximadamente entre 20 e $40 \%$ de fragmentos vegetais que não foram ilustrados no gráfico; por este motivo, não fecham em 100\% Localização dos pontos amostrados na Figura 24.

O sambaqui Encantada III apresenta menor variabilidade de grupos de componentes da fração grossa que Jabuticabeira II, restrita a: bioclastos fragmentados, fragmentos siliciclásticos, bioclastos inteiros e produtos de combustão (Figura 66). No sedimento do entorno do sambaqui Encantada III, somente fragmentos siliciclásticos foram encontrados GS-01, Figura 66).

No sambaqui Carniça III, a fácies "terra preta" apresenta maior quantidade de fragmentos bioclásticos em relação a mesma fácies do sambaqui Encantada III (GS-TP, Figura 66). Enquanto isso, a fácies arenosa contém aproximadamente 15\% de fragmentos acumulados pelo homem, compostos por bioclastos fragmentados, crostas fosfáticas, produtos de combustão e ossos marrons (GS-areia, Figura 67).

Nos sedimentos geogênicos ao lado do sambaqui Carniça I, encontra-se quantidade expressiva de ossos marrons, fragmentos bioclásticos e produtos de combustão (Figura 67), o que pode indicar processos de erosão do sambaqui, dada a proximidade da trincheira de amostragem com o sítio. 


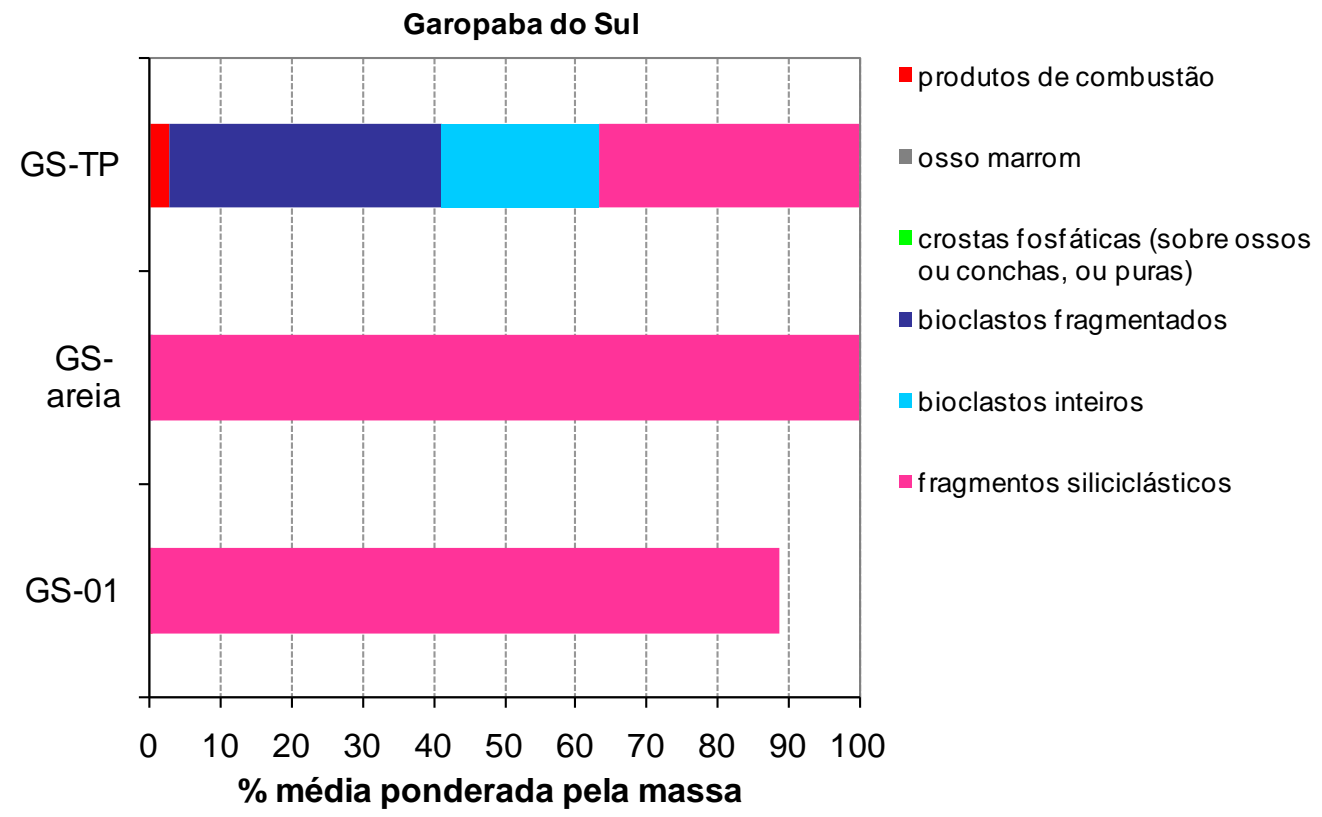

Figura 66 - Distribuição em barra dos resultados da análise da fração grossa das amostras dos sedimentos do sambaqui Encantada III (GS-TP e GS-areia) bem como dos sedimentos geogênicos do entorno (GS-01), expressos em \% por grupo texturalmineralógico (cores da legenda). A amostra GS-01 possui aproximadamente 10\% de fragmentos vegetais que não foram ilustrados no gráfico; por este motivo, não fecha em 100\%. Localização dos pontos amostrados na Figura 25.

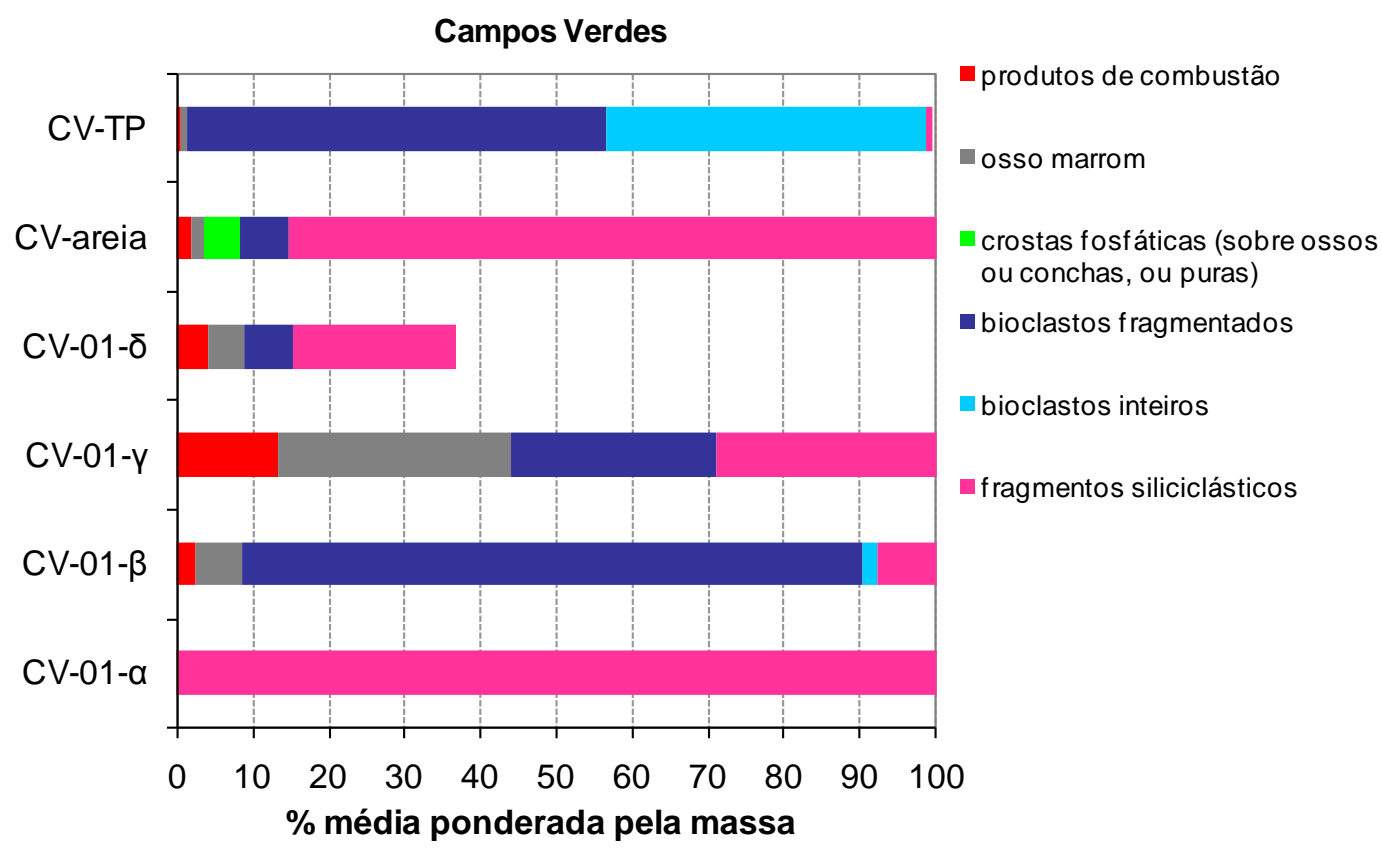

Figura 67 - Distribuição em barra dos resultados da análise da fração grossa das amostras dos sedimentos do sambaqui Encantada III (CV-TP e CV-areia) bem como dos sedimentos geogênicos do entorno (CV-01- $\alpha$ a $\delta$ ), expressos em \% por grupo textural-mineralógico (cores da legenda). A amostra CV-01- $\delta$ possui aproximadamente $60 \%$ de fragmentos vegetais que não foram ilustrados no gráfico, por este motivo, não fecha em 100\%. Localização dos pontos amostrados na Figura 26. 
De modo a esclarecer a relação entre os grupos de componentes analisados no sambaqui Jabuticabeira II, efetuou-se análise de dispersão, com validação das retas de regressão pelo teste t de Student, para alguns destes grupos.

Pela observação da Figura 68, nota-se que, para as fácies "funerárias" e "terra preta" (LC e LA), os fragmentos siliciclásticos, interpretados como de origem geogênica, e os bioclastos fragmentados, possuem correlação negativa. Esta correlação pode indicar uma seleção dos componentes de ambos os grupos pelo agente transportador ou refletir uma condição do depósito geogênico observada em campo, através de trincheiras no domínio paleolagunar: o contraste entre porções predominantemente quartzo-arenosas, geralmente no topo (fragmentos siliciclásticos), e porções predominantemente bioclásticas, na base (colunas estratigráficas das Figura 39, Figura 45 e Figura 49).

Já para as fácies conchíferas, o padrão de correlação negativa entre os grupos supracitados (Figura 68) não se repete; ademais, não há correlação evidente entre estes grupos para as fácies conchíferas.

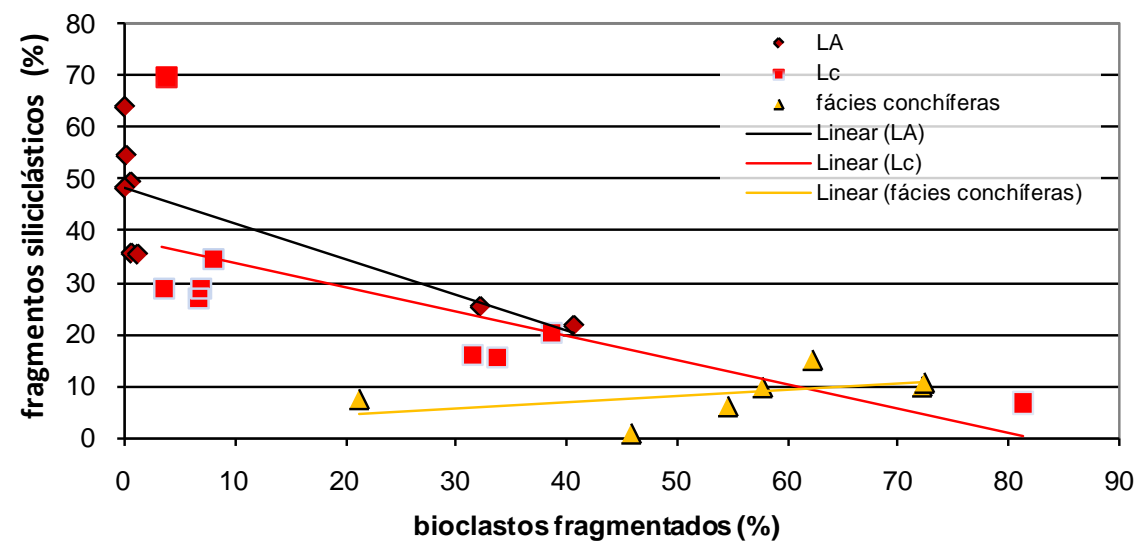

Figura 68 - Diagrama de dispersão dos grupos "fragmentos siliciclásticos" e "bioclastos fragmentados" separados por fácies "funerárias" e "terra preta" (Lc e LA) e "conchíferas" (A $\ell, \mathrm{Cb}, \mathrm{CLb}, \mathrm{C} \boldsymbol{\ell}, \mathrm{CA} \boldsymbol{\ell}$ e Ap) do sambaqui Jabuticabeira II. Para a reta de regressão preta (LA), $\alpha=0,01$; para a reta vermelha (Lc), $\alpha<0,025$; para a reta amarela (fácies conchíferas), $\alpha<0,2$.

Os fragmentos fosfáticos são componentes comumente encontrados no sambaqui Jabuticabeira II, bem como na fácies arenosa do sambaqui Carniça III, cuja origem poderia ser atribuída ao intemperismo de ossos. Porém, não se observa relação estatística, nas lâminas "funerárias" e na capa de "terra preta" do Jabuticabeira II, entre fragmentos fosfáticos e ossos quantificados (Figura 69). Já para as fácies conchíferas, existe correlação positiva entre estes dois componentes, o que pode refletir a tendência de formação de camadas concrecionadas por fosfato nestas fácies, descrita por Mazini \& Giannini (2007) e Nardini et al, (2008). 


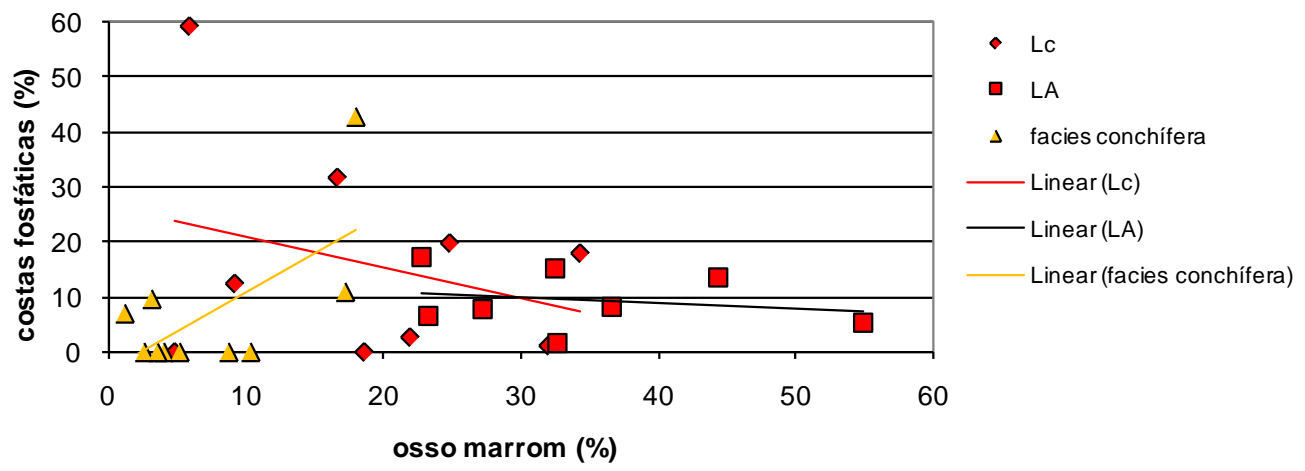

Figura 69 - Diagrama de dispersão dos grupos "crostas fosfáticas" e "osso marrom" separados por lâminas "funerárias" e "terra preta" (Lc e LA) e "conchíferas" (Al, $\mathrm{Cb}, \mathrm{CLb}, \mathrm{Cl}$, CAl e Ap) do sambaqui Jabuticabeira II. Para a reta de regressão preta (LA), $\alpha=0,3$; para a reta vermelha (Lc), $\alpha=0,2$; para a reta amarelaá(fies conchíferas), $\alpha<0,025$.

A presença dos ossos e demais materiais arqueofaunísticos na fácies "terra preta" (LA) do sambaqui Jabuticabeira II foi atribuída a deposição terciária (sensu Schiffer 1983, 1987 apud Villagrán, 2008), consequência de transporte ritual associado aos sepultamentos, cuja fonte seria um depósito secundário materializado por processos ligados a queima, limpeza e transporte do lugar de vida dos sambaquieiros (Villagrán, 2008).

Esta característica, de depósito composto por materiais arqueofaunísticos reciclados de outros depósitos preexistentes, parece evidenciada pela ausência de correlação estatística satisfatória entre o grupo de "produtos de combustão" (que inclui componentes como ossos com diversos graus de alteração térmica) e "ossos marrons", supostamente não alterados termicamente, para qualquer das fácies estudadas (Figura 70). Isto indicaria que as remobilizações sucessivas destes componentes obliteram ou destroem a correlação primariamente existente entre eles.

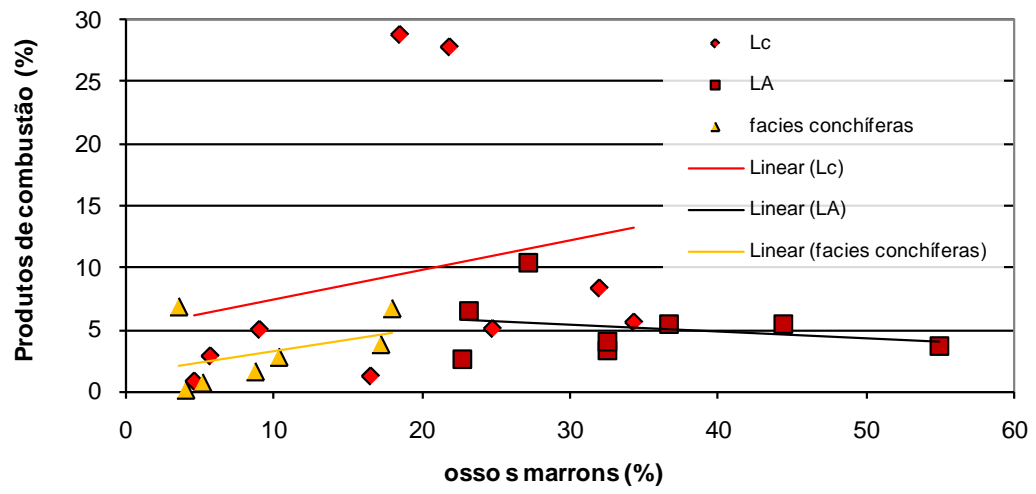

Figura 70 - Diagrama de dispersão dos grupos "produtos de combustão" e "ossos marrons" separados por lâminas "funerárias" e "terra preta" (Lc e LA) e "conchíferas" (Al, $\mathrm{Cb}, \mathrm{CLb}, \mathrm{Cl}$, CAl e Ap) do sambaqui Jabuticabeira II. Para a reta de regressão preta $(L A), \alpha$ (nível de significância) $=0,3$; para a reta vermelha $(L c), \alpha<0,3$; para a reta amarela (fácies conchíferas), $\alpha<0,2$. 


\subsection{Micromorfologia}

O estudo micromorfológico foi aplicado a seções delgadas das recorrências das fácies "funerárias" e da fácies "terra preta" do sambaqui Jabuticabeira II (JB-01 a 16-TP e Interface pacote conchífero-"terra preta") bem como, a título de comparação, a duas seções delgadas de fácies areno-lamosa paleolagunar, correspondentes a amostras coletadas nas proximidades deste sambaqui (JB-poço) e do sambaqui Encantada III (GS-poço). As fichas de descrição de cada lâmina encontram-se no Anexo.

Na maior parte das lâminas estudadas, observa-se predomínio do arcabouço (43\% em média) sobre a matriz (24\%). A proporção de poros avaliada por carta de comparação visual é semelhante à medida com o analisador de imagens (30\% em média). Já os fragmentos de composição fosfática não ósseos ocorrem em concentração média em área de 3\%, na forma de incrustações em conchas (Figura 71), ossos (Figura 72) e outros elementos do arcabouço (Figura 73).

\subsubsection{Arcabouço}

Os componentes mais comuns do arcabouço são quartzo, ossos, conchas, carvão e agregados lamíticos, os quais ocorrem dominantemente na fração areia. O quartzo apresenta-se, na maior parte das amostras, arredondado, com esfericidade alta e seleção granulométrica boa; já os ossos e conchas ocorrem com esfericidade baixa, subangulosos a muito angulosos e com seleção granulométrica pobre, muito pobre, e, raramente, moderada. O carvão ocorre anguloso a muito anguloso, com esfericidade variável e seleção granulométrica variando de pobre a boa. Os agregados lamíticos possuem tessitura-b salpicada e orientada (b-fabric sensu Stoops, 2003), devido à birrefringência característica dos filossilicatos que os compõem (Figura 83). Apresentam forma subangulosa e angulosa, esfericidade baixa e seleção granulométrica moderada a pobre. É comum sua ocorrência na forma de pseudomatriz.

O arcabouço da maior parte das seções delgadas é composto por grande quantidade de quartzo arredondado e subarredondado, com sobrecrescimento sintaxial em algumas amostras (JB-02 TP, JB-04 TP) e raros grãos policristalinos. Igualmente em grande quantidade, há fragmentos de ossos, em diversos graus de calcinação (Figura 75), e bioclastos carbonáticos derivados de valvas de moluscos.

Os também freqüentes agregados lamíticos ricos em diatomáceas (Figura 78b) inteiras e fragmentadas são muito semelhantes aos descritos por Amaral (2008, p. 44) para a fácies "argila arenosa maciça com conchas" (base do testemunho RIA), encontrada em sedimentos 
paleolagunares no vale do Riachinho, distante aproximadamente $5 \mathrm{~km}$ da laguna Garopaba do Sul. A semelhança é reforçada pelo conteúdo fossilífero de diatomáceas, cuja presença marcante de Paralia sulcata, dentre outras espécies, coincide com o encontrado por aquela autora.

Os raros fragmentos de calcedônia assemelham-se a estilhas (Figura 79), resultado de fragmentação por choque mecânico de seixos de calcedônia. Evidências são a margem irregular e o acunhamento de borda.

Outros fragmentos encontrados incluem agregados de provável clorita (Figura 80), torrões de argila vermelha contendo diatomáceas, nódulos disórticos (mesma composição, porém translocados) e anórticos (formados fora do contexto atual, transportados - Figura 81), estes cimentados por fosfatos ou não, pelotilhas (pellets), raros fragmentos de rocha basáltica (Figura 82) e torrões de óxi-hidróxidos de ferro.

O revestimento observado em parte das amostras é composto por fosfato isótropo a ligeiramente anisótropo, com textura botrioidal, esferulítica e também microlaminada, freqüentemente recoberto pela micromassa (Figura 86 e Figura 87).

As incrustações fosfáticas acham-se, em grande parte das vezes, fora de contexto original (Figura 74). Evidências disso são sua ocorrência dispersa na matriz, sem orientação preferencial, às vezes com indicativos geopetais tanto de topo como de base, em uma mesma lâmina. Comportam-se assim como um elemento do arcabouço, ou seja, trata-se de material alóctone, apesar da presumível origem química mediata. A característica alóctone deste revestimento fosfático é reforçada pelas observações em lupa, conforme descrito no item 5.5: a completa ausência de fragmentos fosfáticos nas fácies sotopostas às portadoras (Figuras 64 e 69) é contrária ao que seria esperado caso a formação dos revestimentos/fragmentos fosfáticos se desse por processos de lixiviação.

Em menor quantidade, porém bastante freqüentes, encontram-se fitólitos, tecidos vegetais deformados termicamente e associados à escória vítrea (Figura 76 e Figura 77) e fragmentos de carvão (Figura 78a). Todos estes elementos parecem ocorrer associados tanto no arcabouço como também na micromassa, em quase todas as frações granulométricas 
a)

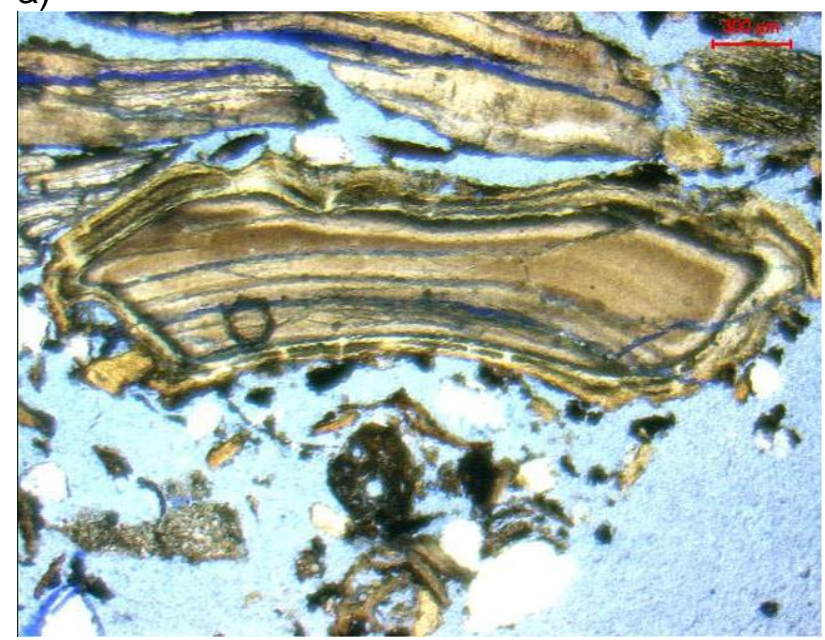

b)

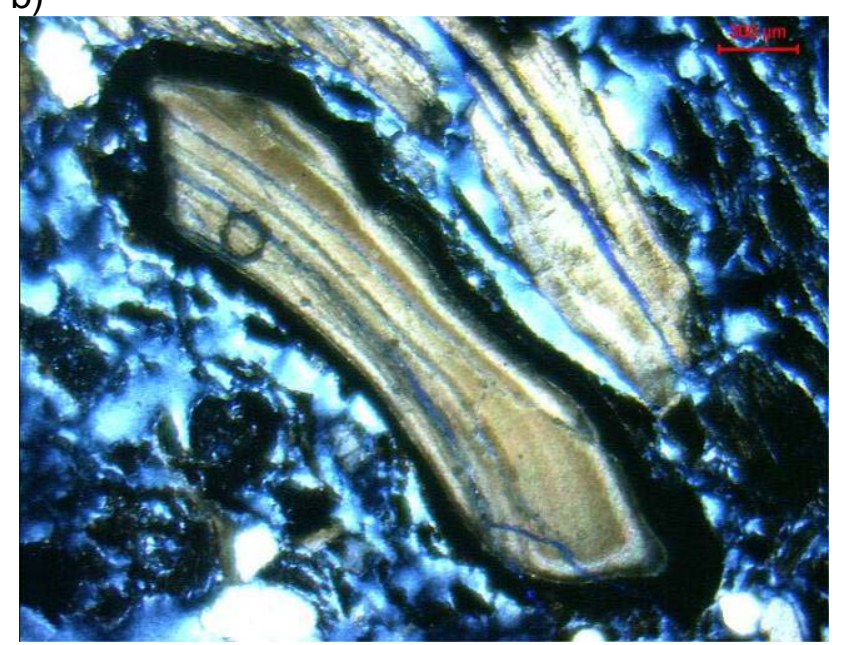

Figura 71 - Fotomicrografia de fragmento de concha carbonática totalmente envolvido por revestimento fosfático (isótropo na foto $b$ ). Polarizadores paralelos (PPL) (a), polarizadores cruzados (XPL) (b). Amostra JB-01-TP.

a)

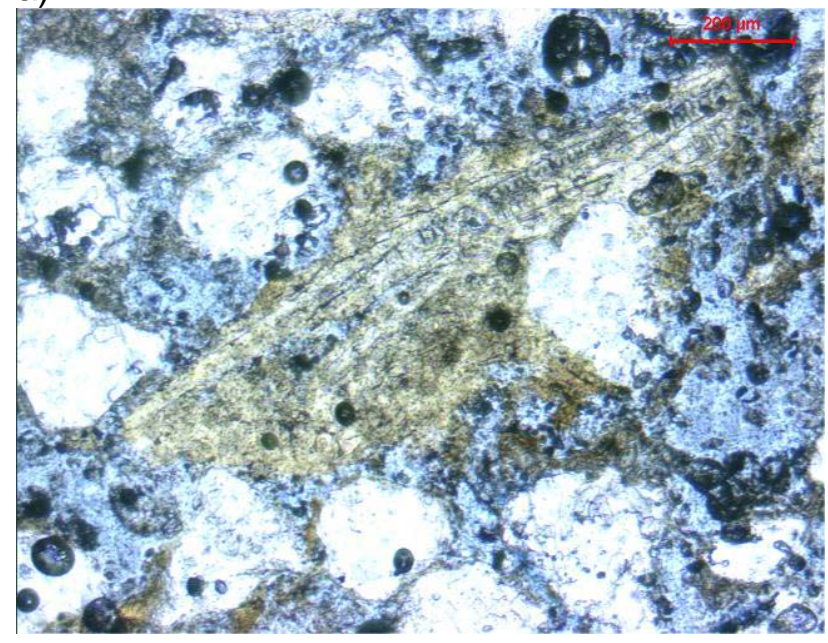

b)

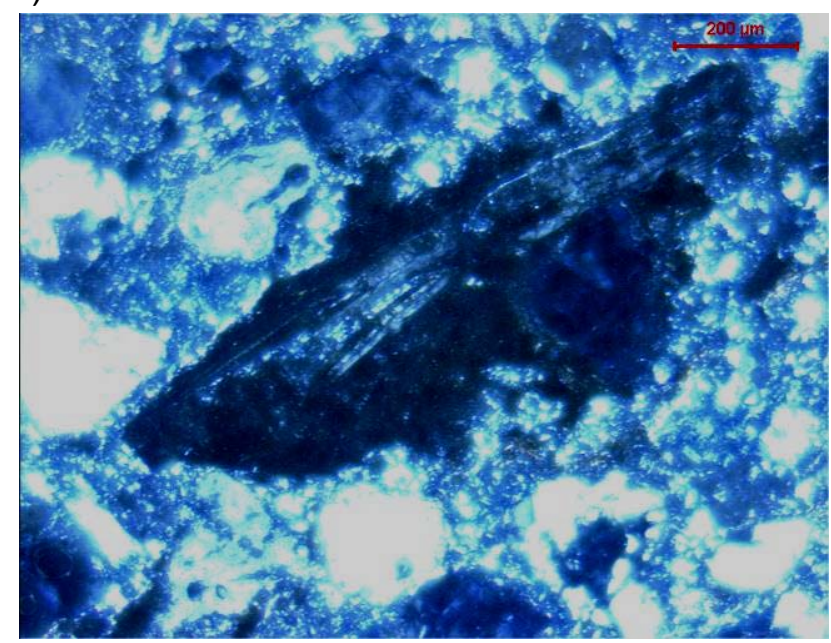

Figura 72 - Fotomicrografia de fragmento de osso totalmente envolvido por revestimento fosfático (isótropo, em b). Notar que o fragmento de osso possui fraca birrefringência (b). Polarizadores paralelos (PPL) (a), polarizadores cruzados (XPL) (b). Amostra JB-06-TP. 
a)

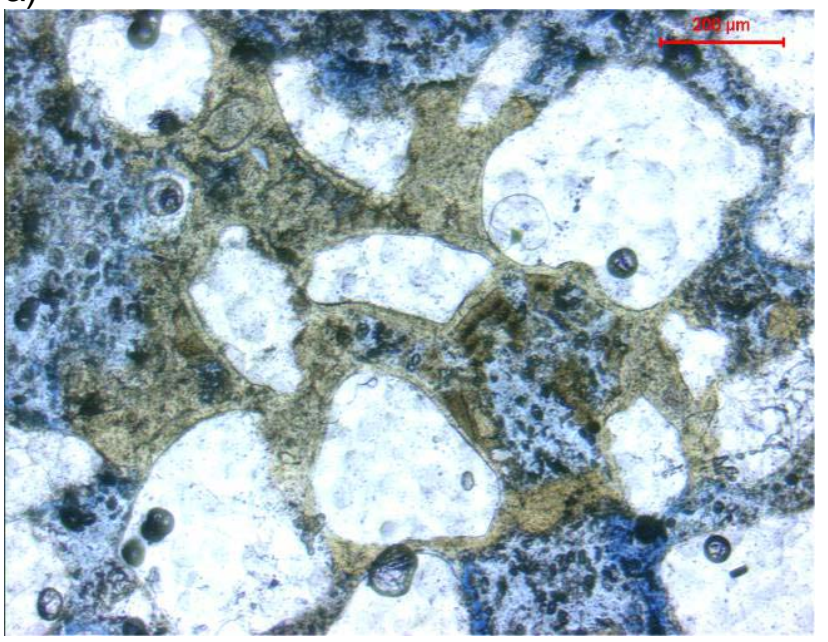

b)

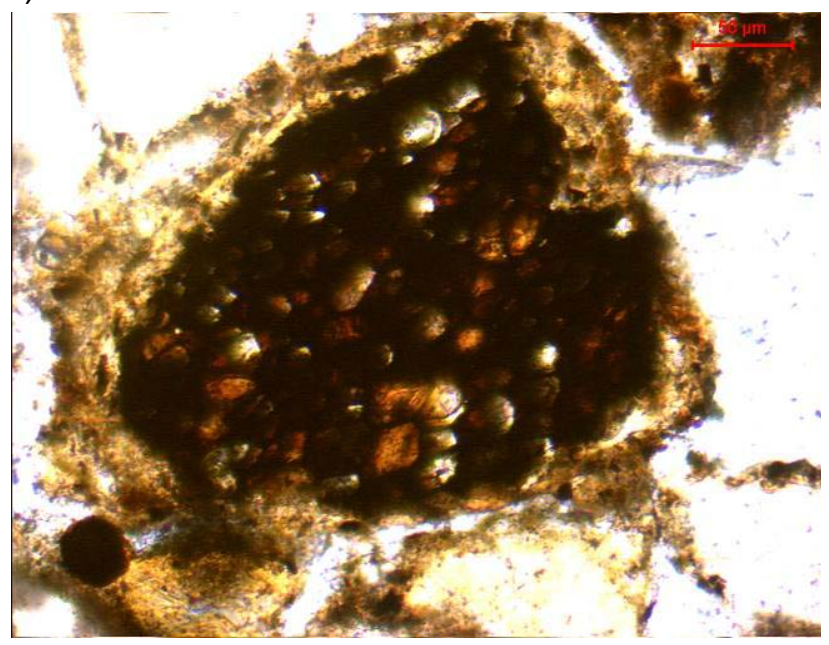

Figura 73 - Fotomicrografia de grãos de quartzo parcial a totalmente envolvidos por revestimento fosfático (a), semelhante ao fragmento da Figura 59a, e envolvendo totalmente um fragmento de carvão (b). Notar que os poros do carvão também se encontram preenchidos por fosfato. a e b: PPL. Topo para cima (a) e para canto superior esquerdo (b). Amostras JB12-TP (a) e JB-06-TP (b).

a)

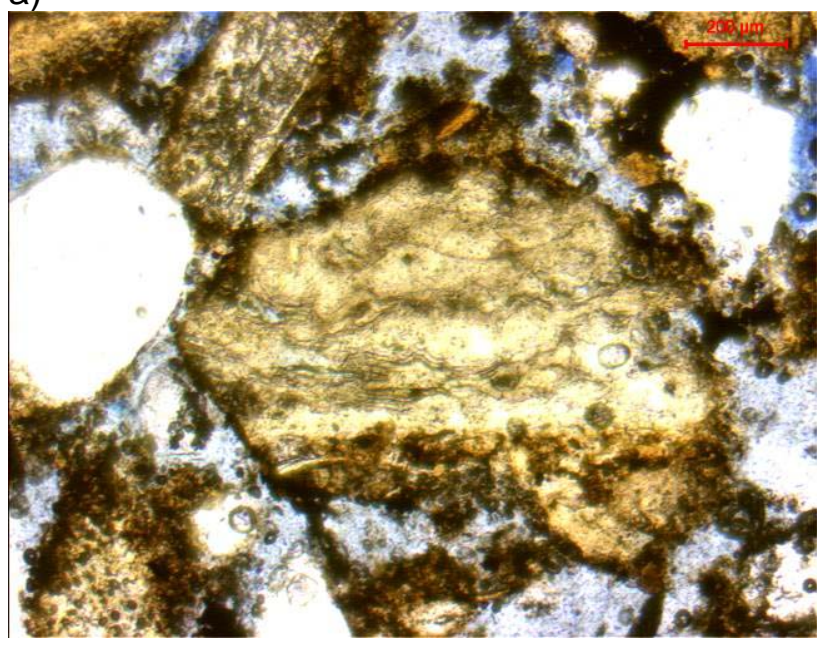

b)

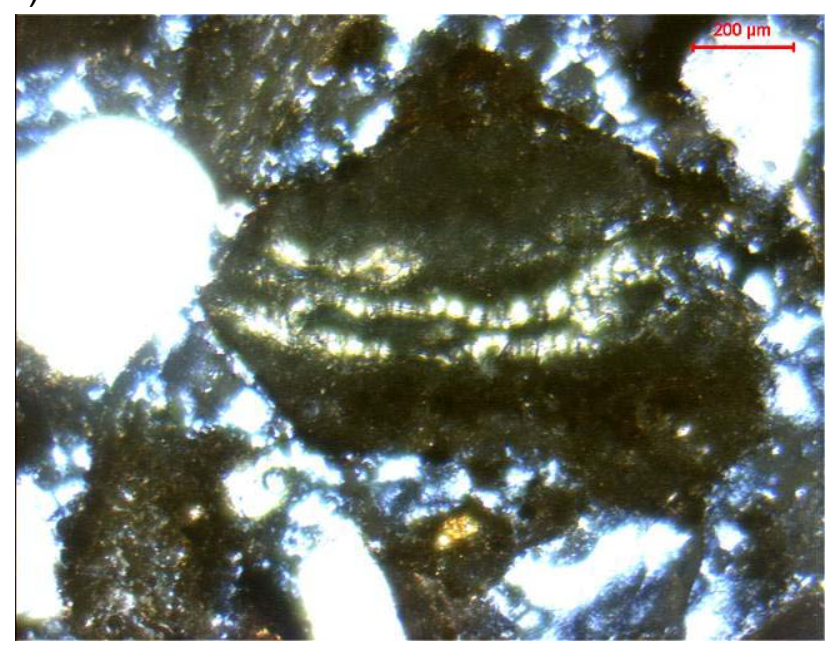

Figura 74 - Fotomicrografia de fragmento fosfático envolvido por micromassa amarronzada, denotando o carácter alóctone deste fragmento no depósito estudado. PPL (a), XPL (b). Amostra JB-12-TP. Notar que a birrefringência no centro do fragmento, em b, indica a textura botrioidal. 
a)

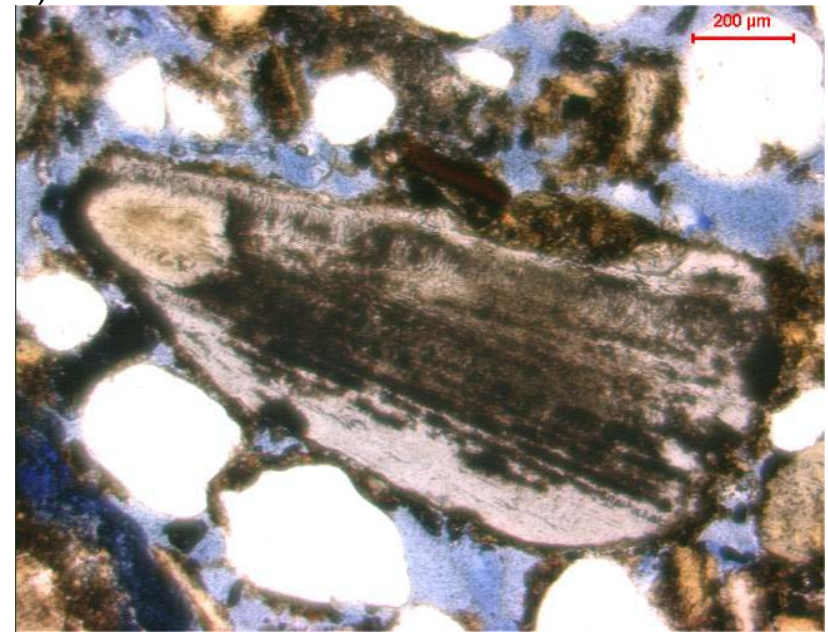

b)

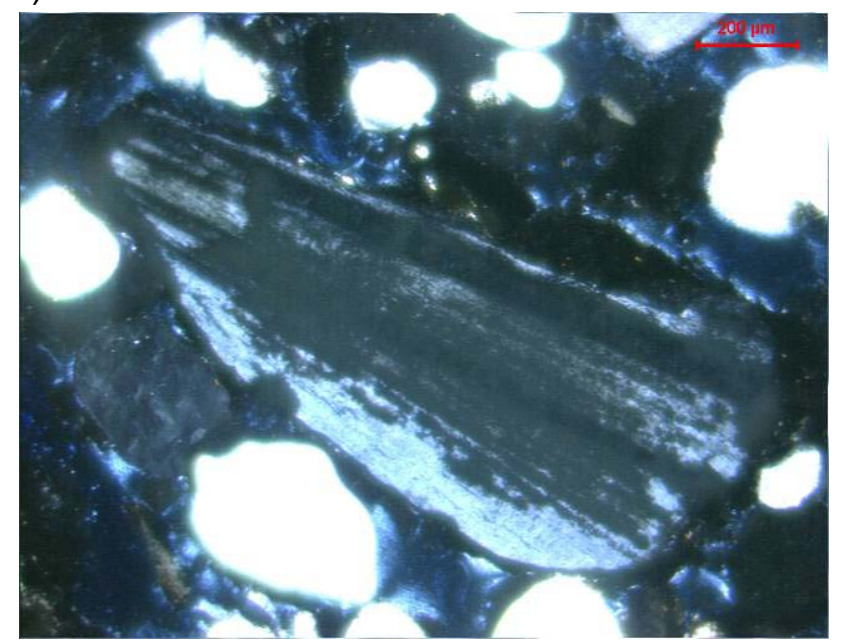

Figura 75 - Fotomicrografias de osso de cor azulada (a) e birrefringência semelhante a da apatita mineral (b). Estas características ópticas são compatíveis com ossos submetidos à alta temperatura. PPL (a), XPL (b). Amostra JB-15-TP.

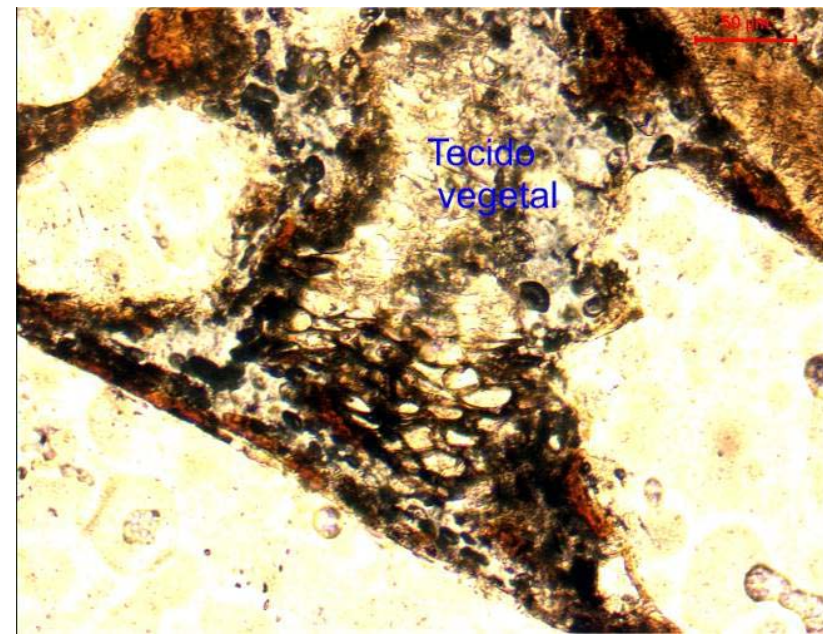

Figura 76 - Fotomicrografia de tecido vegetal deformado termicamente. PPL. Amostra JB06-TP. 
a)

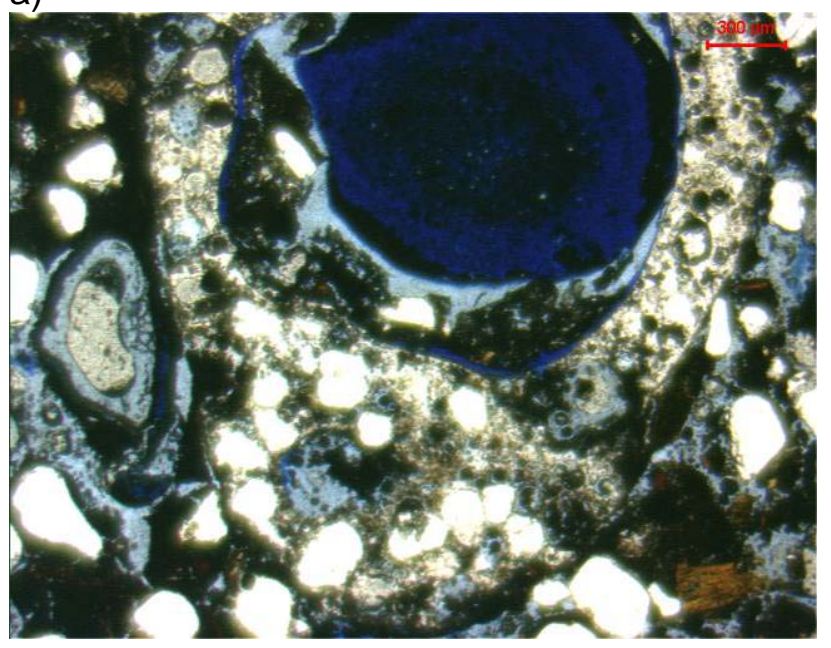

b)

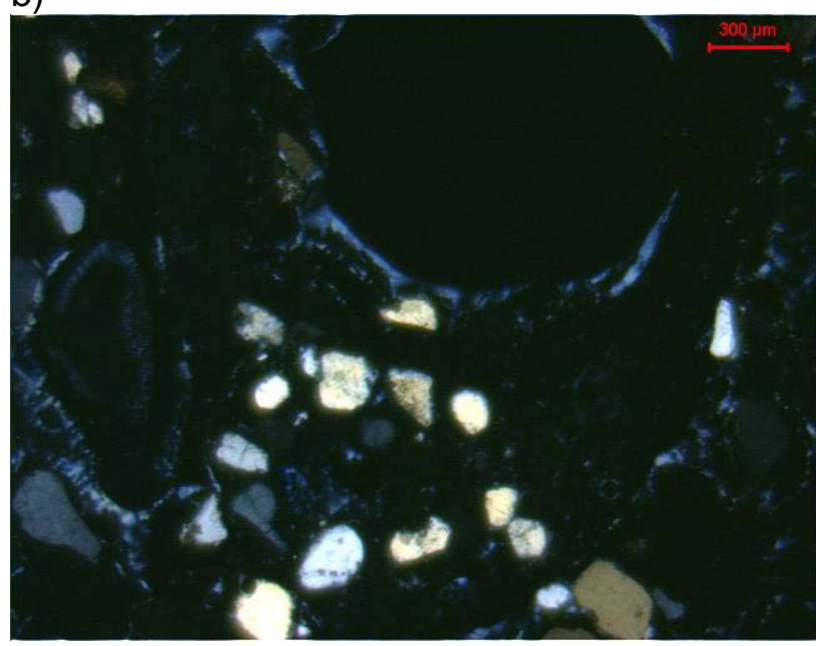

Figura 77 - Fotomicrografias de escória vítrea englobando grãos de quartzo. Nota-se que o quartzo se apresenta íntegro, indicando fusão de sílica sob temperatura inferior ao ponto de fusão do mineral. PPL (a), XPL (b). Amostra JB-07-TP.

a)

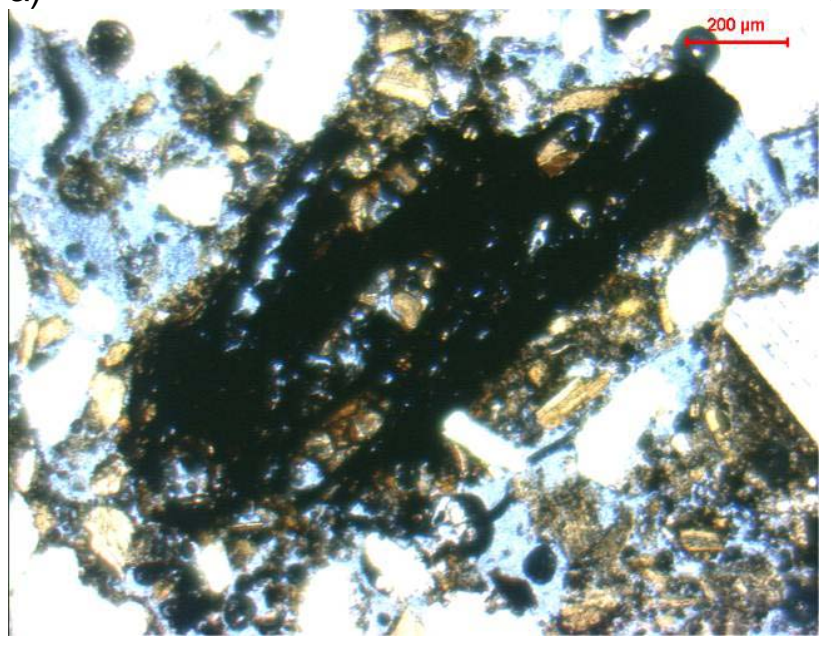

b)

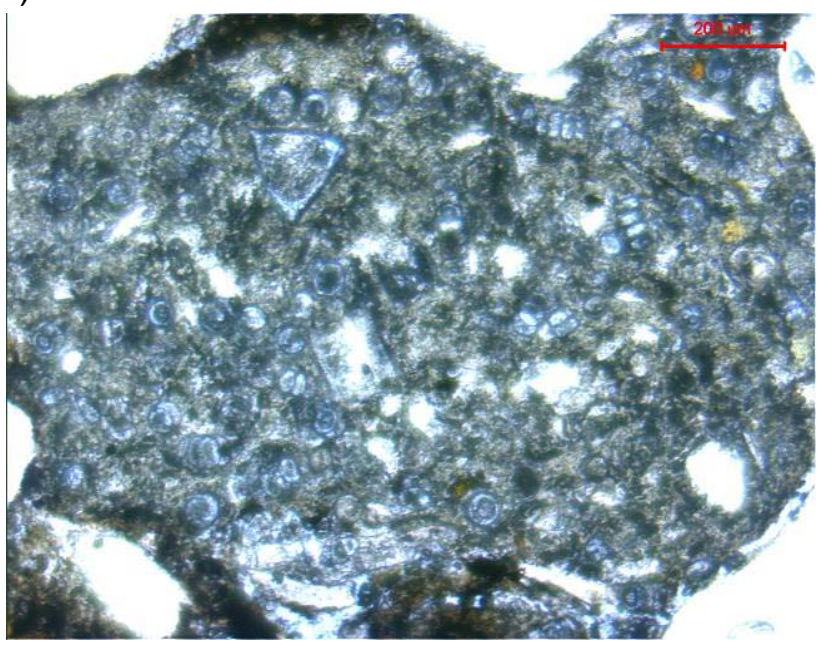

Figura 78 - Fotomicrografias de fragmento de carvão com impregnação fosfática marrom alaranjada (a) e fragmento de lamito contendo grande número de diatomáceas (b), semelhante ao agregado lamítico da Figura 59. PPL. Amostras JB-13-TP (a) e JB-06-TP (b). 
a)

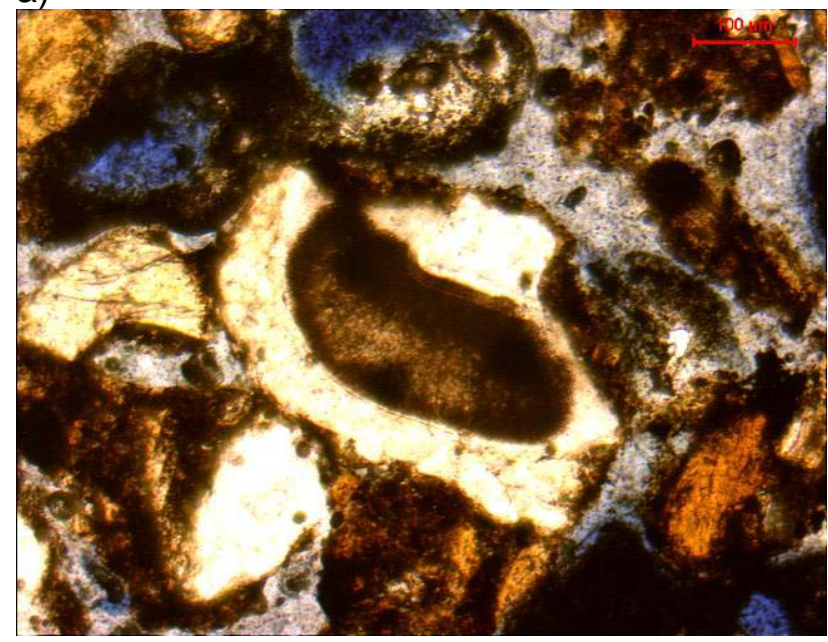

b)

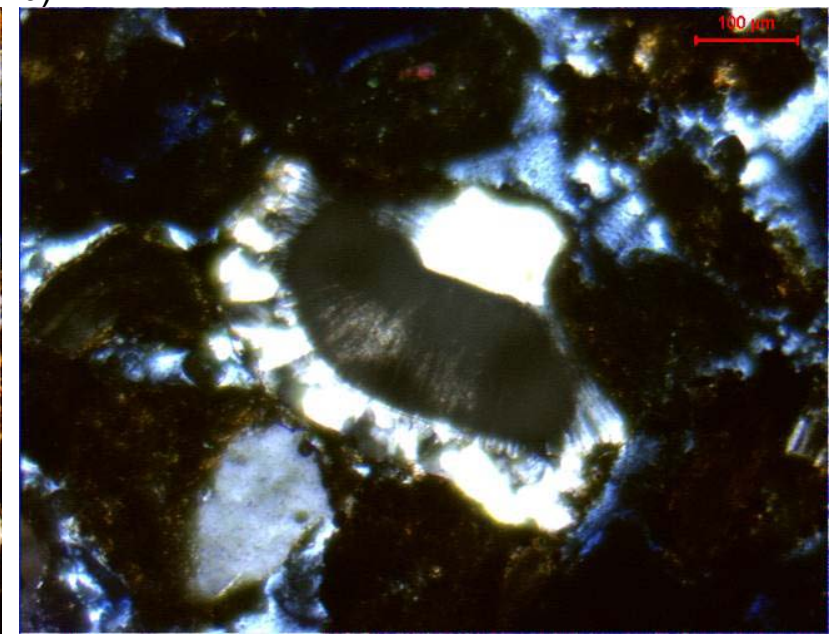

Figura 79 - Fotomicrografias de fragmento de calcedônia fibrorradiada, interpretado como provável estilha. PPL (a) e XPL (b). Amostra JB-12-TP.

a)

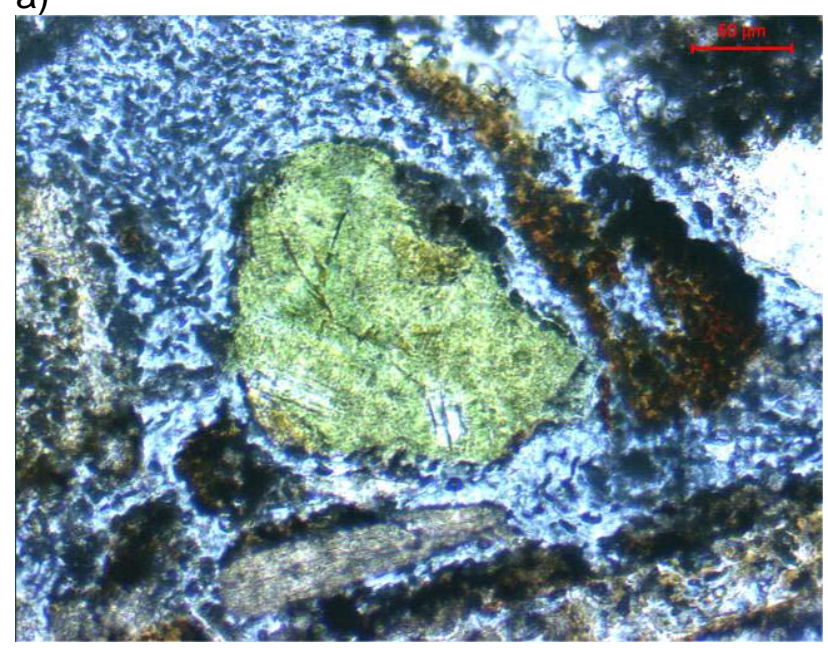

b)

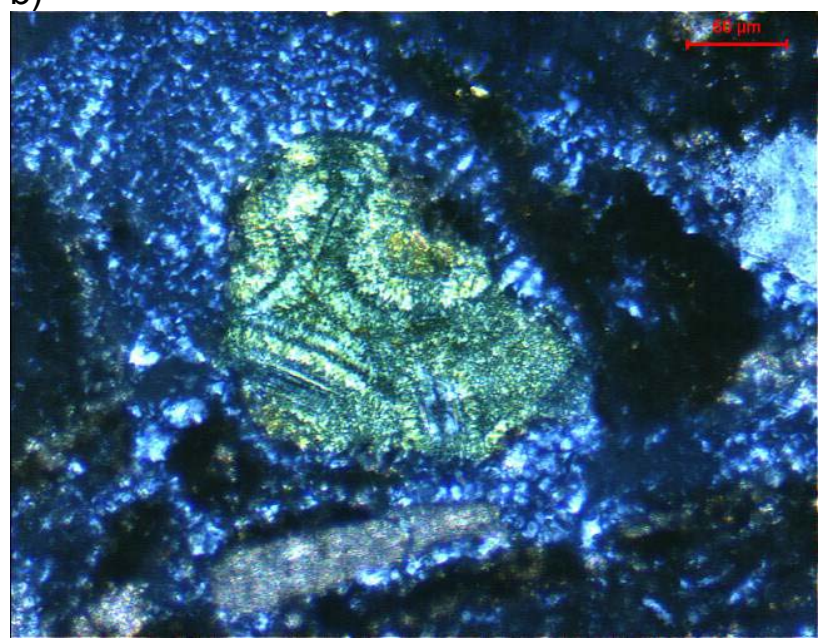

Figura 80 - Fotomicrografias de agregado em arranjo radial, composto predominantemente por provável clorita (b). PPL (a) e XPL (b). Amostra JB-04-TP.

a)

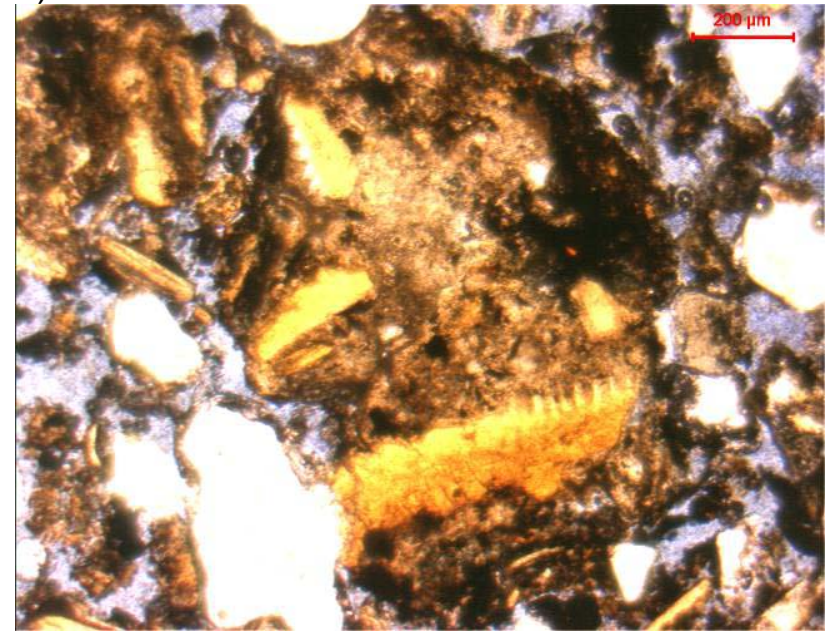

b)

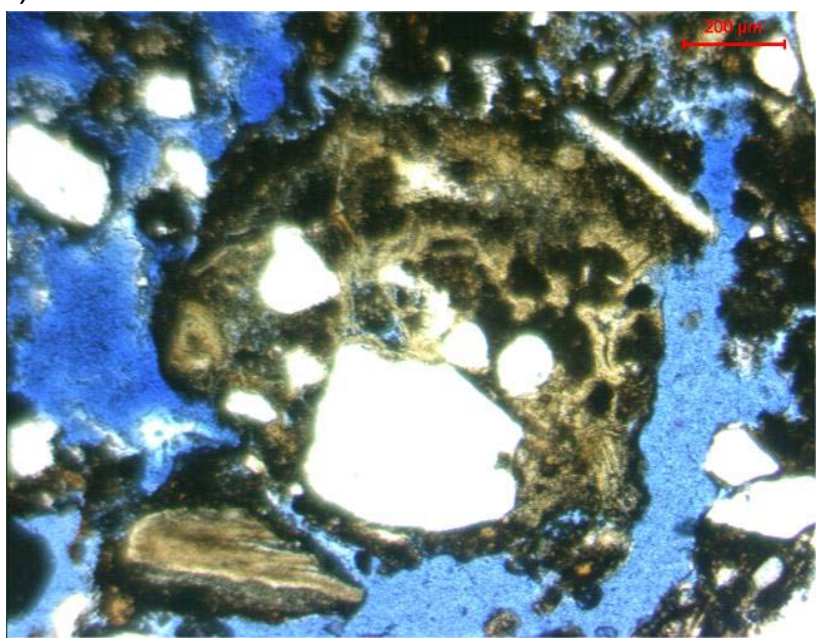

Figura 81 - Fotomicrografias de nódulos disórtico (a) e anórtico com cimentação fosfática (b). PPL. Amostra JB-13-TP (a) e, amostra JB-16-TP (b). 
a)

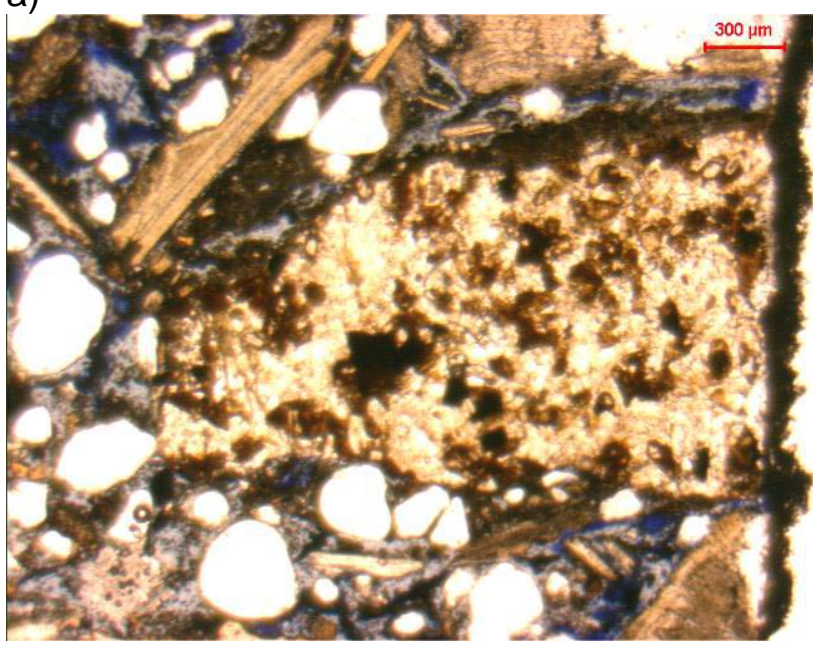

b)

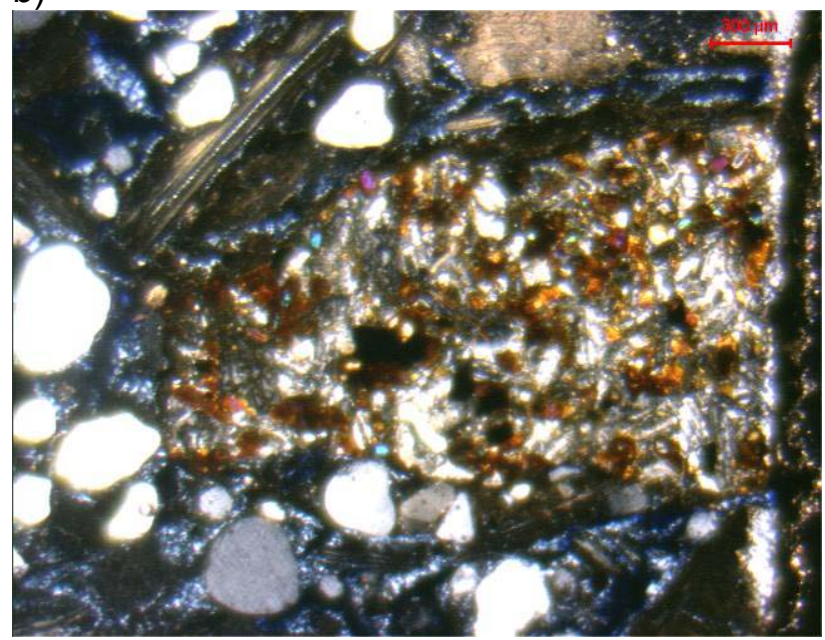

Figura 82 - Fotomicrografias de fragmento de rocha basáltica. PPL (a) e XPL (b). Amostra JB11-TP.

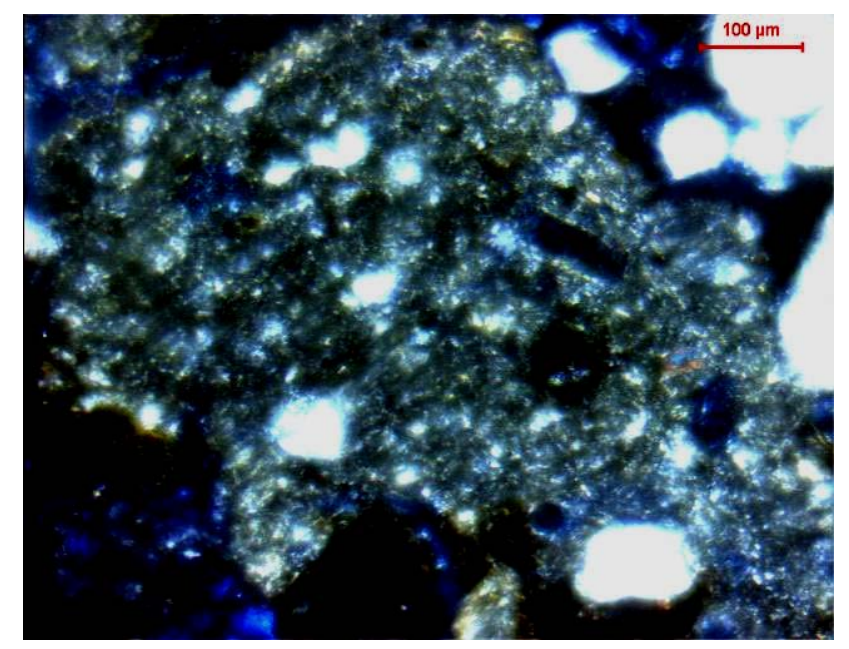

Figura 83 - Fotomicrografia de tessitura b salpicada. Os grãos brancos maiores são de quartzo. XPL. Amostra JB-12-TP.

Figura 84 - Fotomicrografia de fragmento vegetal carbonizado contendo carbonato (calcimicrita), provavelmente formado a partir de oxalato de cálcio vegetal calcinado. Amostra JB-06-TP.

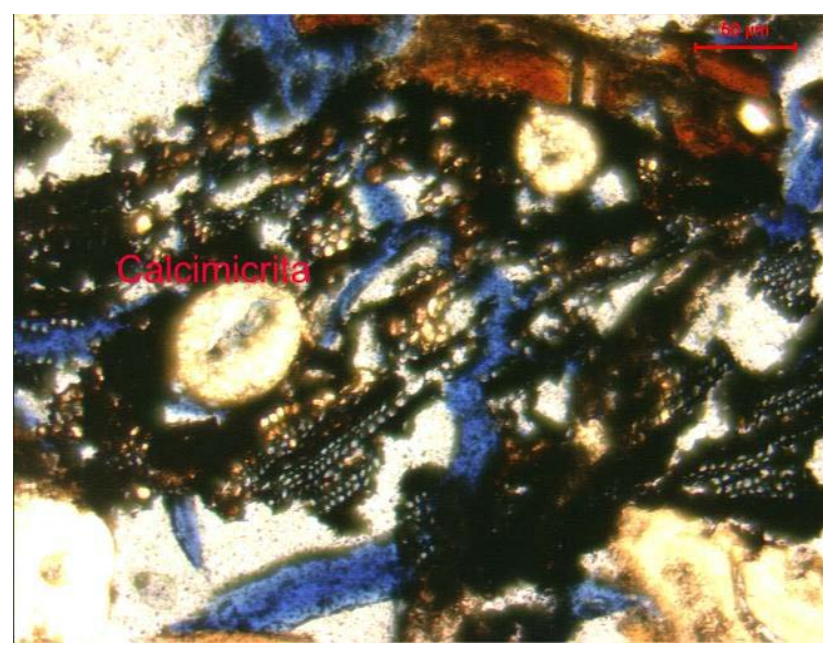


a)

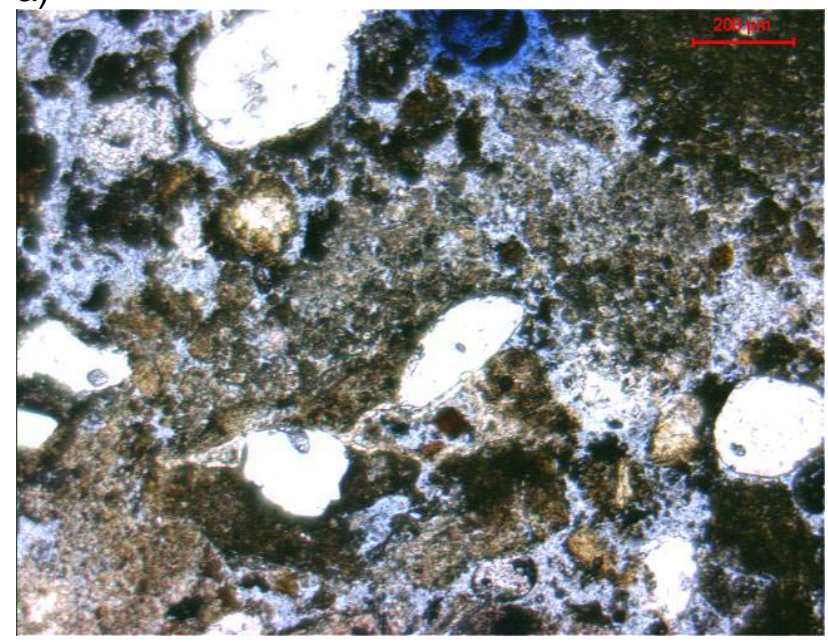

b)

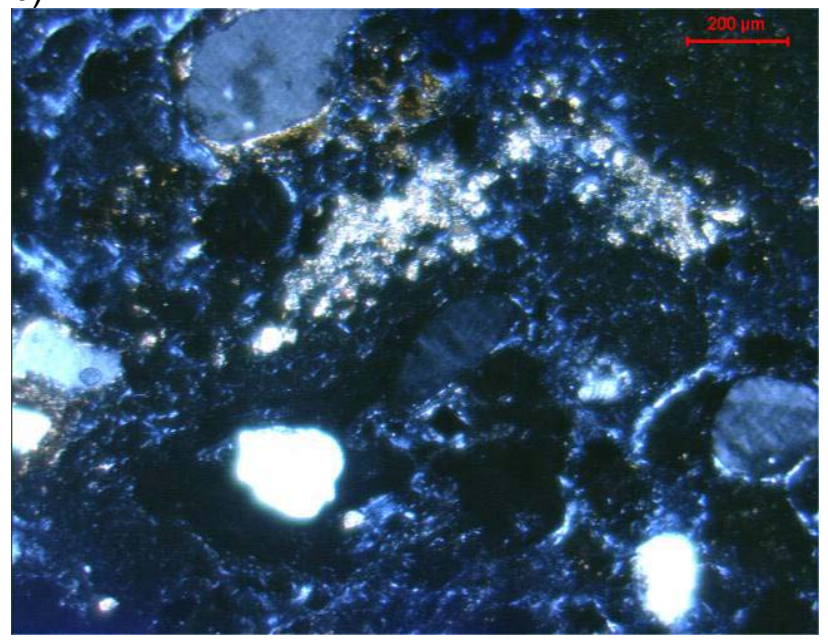

Figura 85 - Fotomicrografias de fragmento vegetal termicamente alterado, restando apenas agregados circulares de calcimicrita (arredondados e birrefringentes), em substituição aos esferulitos de oxalato de cálcio de origem vegetal (b). PPL (a) e XPL (b). Amostra JB-07-TP.

a)

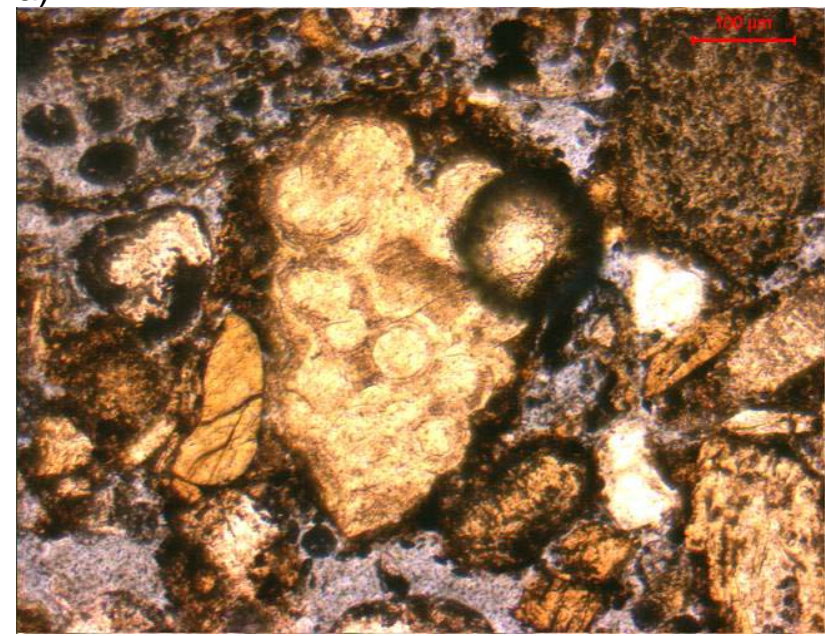

b)

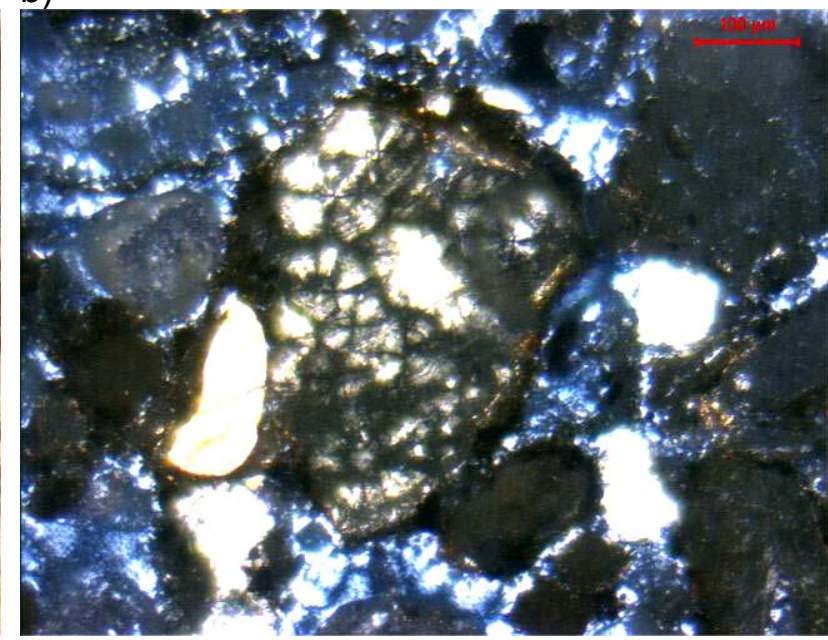

Figura 86 - Fotomicrografias de fragmento fosfático contendo esferulitos (b). Esta feição é correlacionável a coprólitos humanos (Paul Goldberg, comunicação pessoal). PPL (a) e XPL (b). Amostra JB-13-TP. 
a)

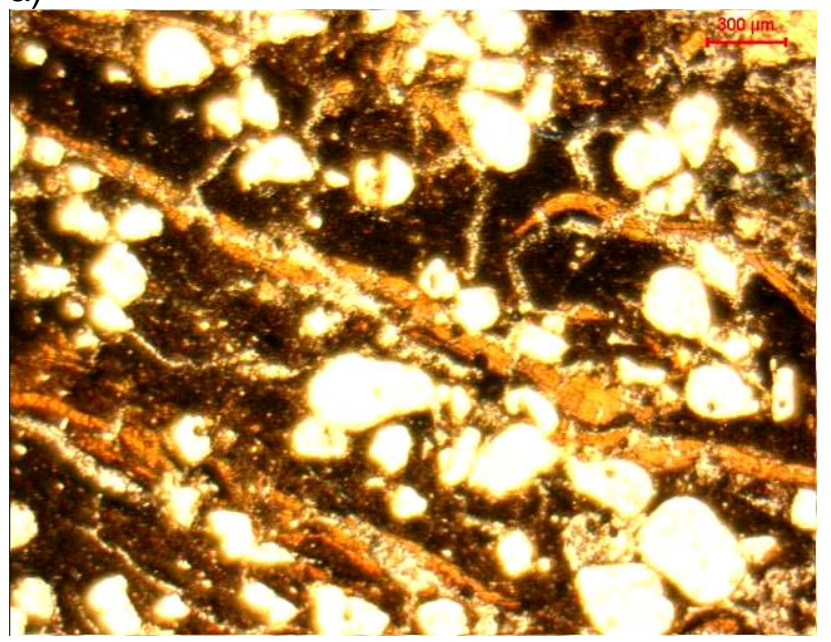

b)

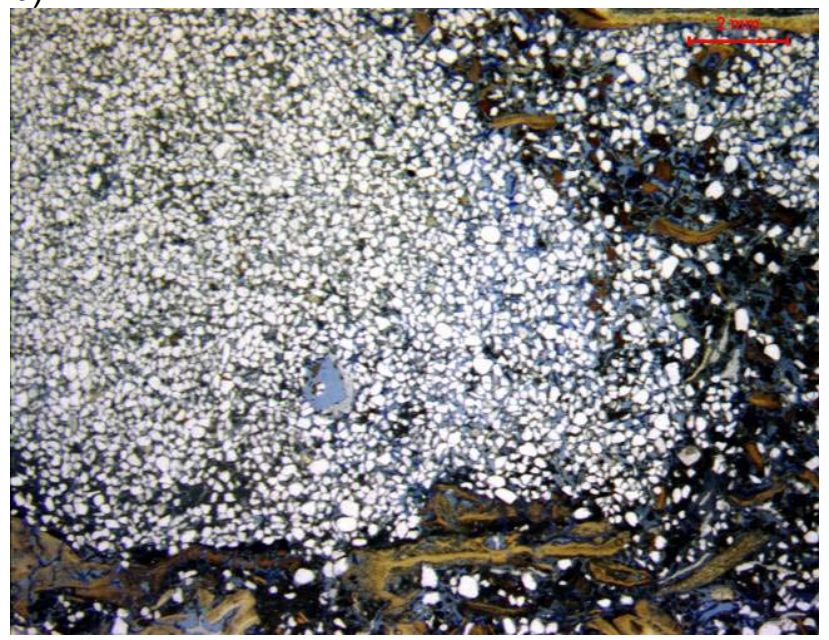

Figura 87 - Fotomicrografia de laminação fosfática (linhas mais finas alaranjadas em a), microestrutura atribuída ao pisoteamento de material rico em $\mathrm{P}$, como esterco (Courty et al, 1989; Shahack-Gross \& Finkelstein, 2008) ou outro material protéico decomposto. Foto sob lupa ilustrando lente quartzo arenosa sem matriz (mónica, em b). PPL. Amostra JB-06-TP.

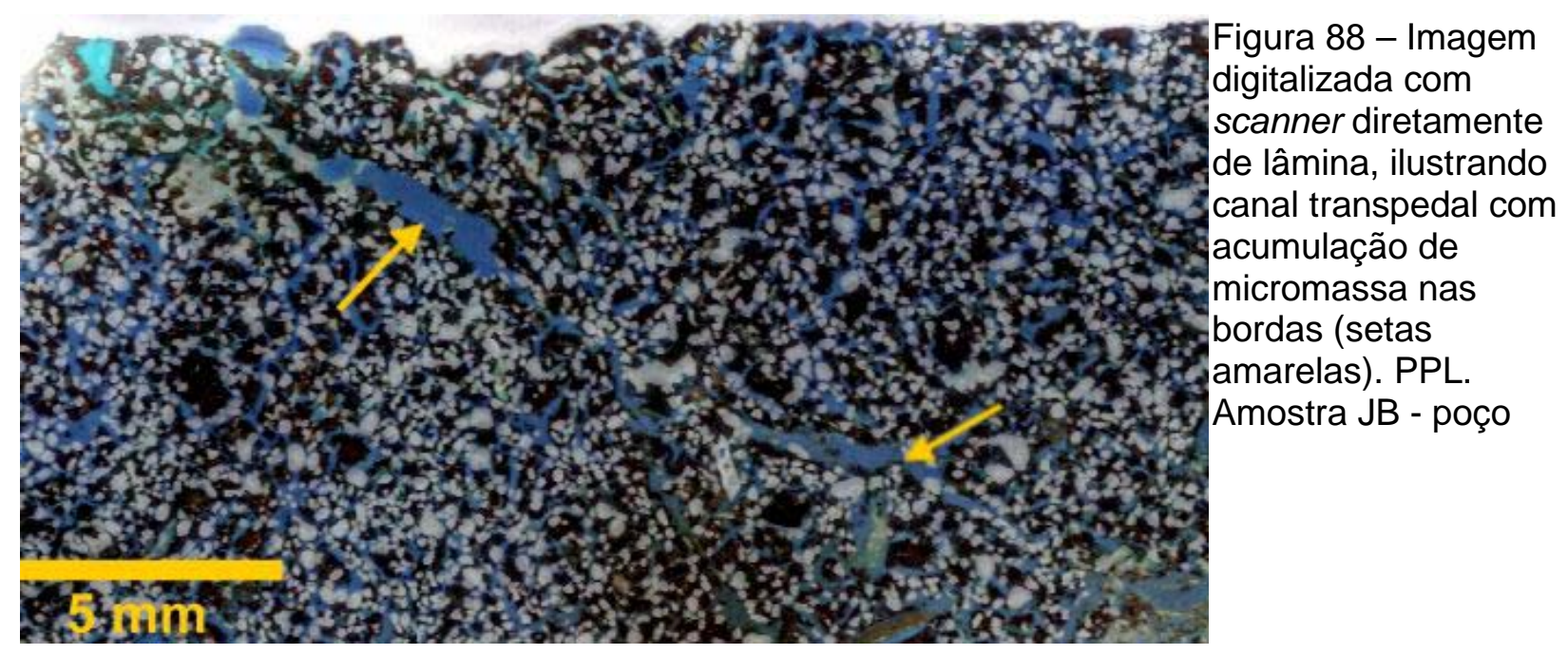

\subsubsection{Matriz e micromassa}

A matriz da maioria das amostras estudadas é microgranular e porosa (crumbs sensu Stoops, 2003) e contém fragmentos pulverizados de carvão e ossos em micromassa isótropa. Algumas amostras apresentam carbonato micrítico (JB-01, 04, 03, 05, 07, 08, 09, 10, 11 TP e interface), distribuído heterogeneamente ou associado aos tecidos vegetais (Figura 84 e 96). É comum a aderência parcial a total da matriz aos grãos do arcabouço, principalmente se na presença de carbonatos. 


\subsubsection{Vazios}

Quase a totalidade das amostras apresentou vazio de empacotamento complexo ou porosidade de heterogeneidade de empacotamento. Em algumas amostras, principalmente as de sedimentos geogênicos, foi possível observar cavidades e canais transpedais preenchidos por pelotilhas e vazios, bem como com acumulação de micromassa nas bordas (Figura 88).

\subsubsection{Arranjo}

Em relação à petrotrama, algumas seções delgadas apresentam segregação granular composicional, associada a presença de microlâminas (espessura micrométrica) compostas principalmente de carvão, ossos queimados e fosfato (JB-01, 02, 04 e 06 TP - Figura 87a), semelhantes às microlaminações descritas por micromorfólogos em contexto arqueológico e interpretados como resultante de pisoteamento (Courty et al., 1989; Shahack-Gross \& Finkelstein, 2008), o que não exclui a possibilidade de deposição laminar. Outras feições da trama são: faixa de conchas na base (JB-06 TP), acúmulo em concavidade de conchas (GSpoço) e em lentes compostas de quartzo arenoso sem matriz (distribuição g/f mónica ${ }^{10}$ ) (JB06 TP - Figura 87b). Já a segregação granular de tamanho é raramente observada; onde presente, associa-se a contrastes granulométricos de grãos de quartzo (JB-10 TP). Observase orientação sub-horizontal de conchas e ossos em parte das amostras (JB-01, 04, 07, 08, 10, 11 TP e interface-pacote conchífero), bem como diagonal e subvertical (JB-02, 03, 05, 06 e 15 TP). No restante das lâminas estudadas, porém, a petrotrama é aparentemente caótica.

Dois aspectos da relação entre arcabouço e matriz merecem destaque: segregação em lâminas de fitólitos e matriz (JB-08 TP) em relação ao arcabouço e segregação por concentração de matriz em paredes de canais de fitoturbação (JB-14 TP, JB-poço e GSpoço); este último pode ser considerado como uma pedofeição sensu Stoops (2003).

A distribuição de grossos e finos do tipo enáulica fina a grossa, de espaçamento simples a duplo, é comum em grande parte das amostras, o que é compatível com o aspecto microestrutural de agregados porosos intergranulares. Boa parte das amostras também apresenta microestrutura de grãos com película e grãos interligados por matriz microagregada.

${ }^{10}$ Mónica: Segundo Stoops (2003), refere-se a um tipo de distribuição g/f onde estão presentes apenas unidades de tessitura (arcabouço, neste trabalho) grossa (mónica grossa) ou fina (mónica fina) em relação a um dado limite g/f e associado à vazios intersiticais, sem a presença de outras frações intersticiais (matriz ou cimento em petrografia sedimentar). 


\subsubsection{Empacotamento}

Nota-se discrepância entre as medidas de proximidade de empacotamento horizontal (perpendicular ao topo) e vertical (paralela ao topo) em depósitos de sambaquis, sendo que nove de 16 medidas apontam valor maior no sentido horizontal (Figura 89). Mesma tendência é observada nos resultados obtidos em depósitos geogênicos (JB poço e GS poço), embora a discrepância entre medidas horizontais e verticais seja aí bem menor. As maiores diferenças entre os valores de medidas verticais e horizontais nos sedimentos antropogênicos, em comparação com os geogênicos, demonstra maior heterogeneidade de empacotamento.

Em valores absolutos, a proximidade de empacotamento dos sedimentos oriundos do sambaqui é, em grande parte das amostras, maior que nos depósitos geogênicos. O empacotamento mais fechado nos sambaquis pode ser atribuído a pisoteamento.

\subsubsection{Porosidade}

As tendências de variação de porosidade (indicadas por setas na Figura 90) são inversas às encontradas na variação de proximidade de empacotamento (Figura 89). Admitida a hipótese de diminuição da porosidade por pisoteamento, aventada no subitem anterior, esta inversão de comportamento entre as duas variáveis indica que o pisoteamento contribui também para a redução da porosidade.

Ainda com referência à Figura 90, os valores absolutos de porosidade da fácies "funerárias" e "terra preta" do sambaqui Jabuticabeira II (TP) são, em média, superiores a semelhantes aos medidos na amostra de fácies areno-lamosa paleolagunar nas proximidades deste sambaqui e, inferiores aos medidos em sedimento paleolagunar de área próxima ao sambaqui Encantada III. Admitida mais uma vez a hipótese de perda de porosidade por efeito de pisoteamento nas áreas mais ocupadas pelo sambaquieiro, a semelhança de porosidade entre as fácies "funerárias" e "terra preta" do sambaqui Jabuticabeira II e os sedimentos geogênicos locais seria um indício de ocupação, pelo sambaquieiro, das margens lagunares da época. Esta interpretação é reforçada pela presença de líticos e vestígios de combustão em meio aos sedimentos paleolagunares vizinhos a este sítio, conforme mencionado no item 5.5. 


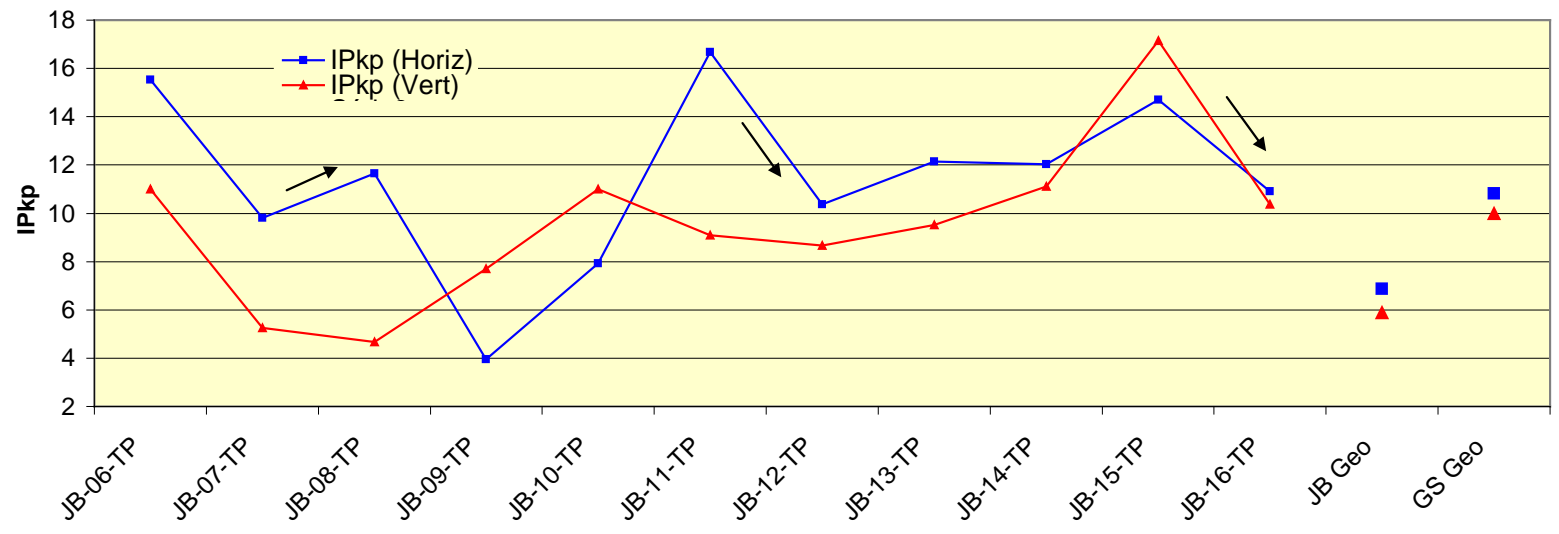

A

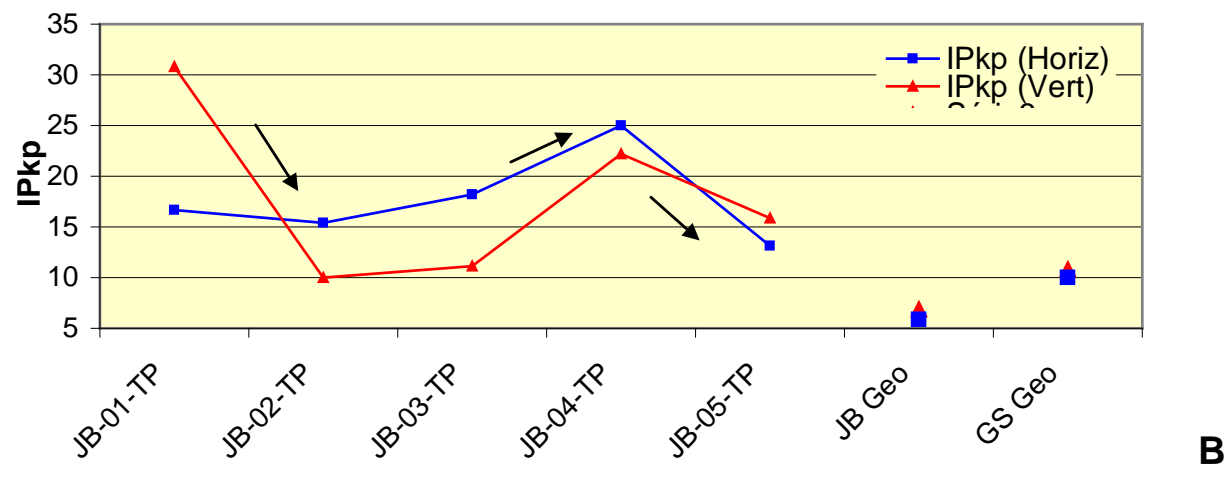

Figura 89 - Variação do índice de proximidade de empacotamento na horizontal (azul) e na vertical (vermelho). As setas indicam as tendências de variação dos dados obtidos. Lócus 1 (A) e lócus 2 (B). 


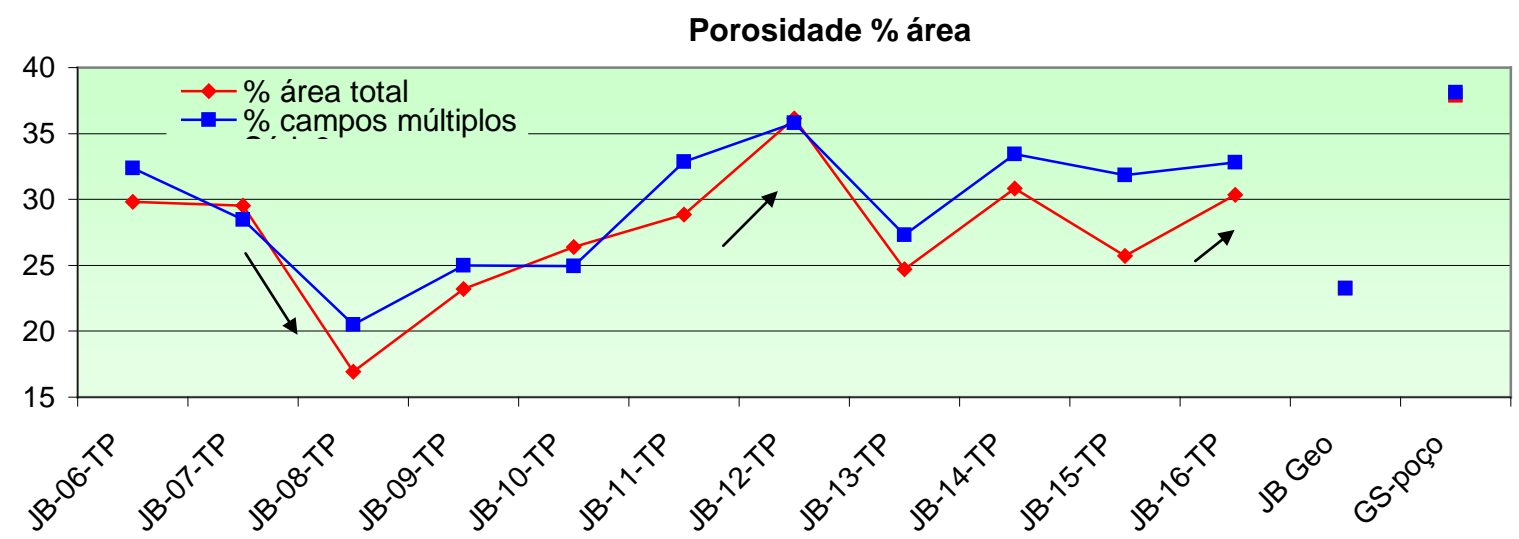

A

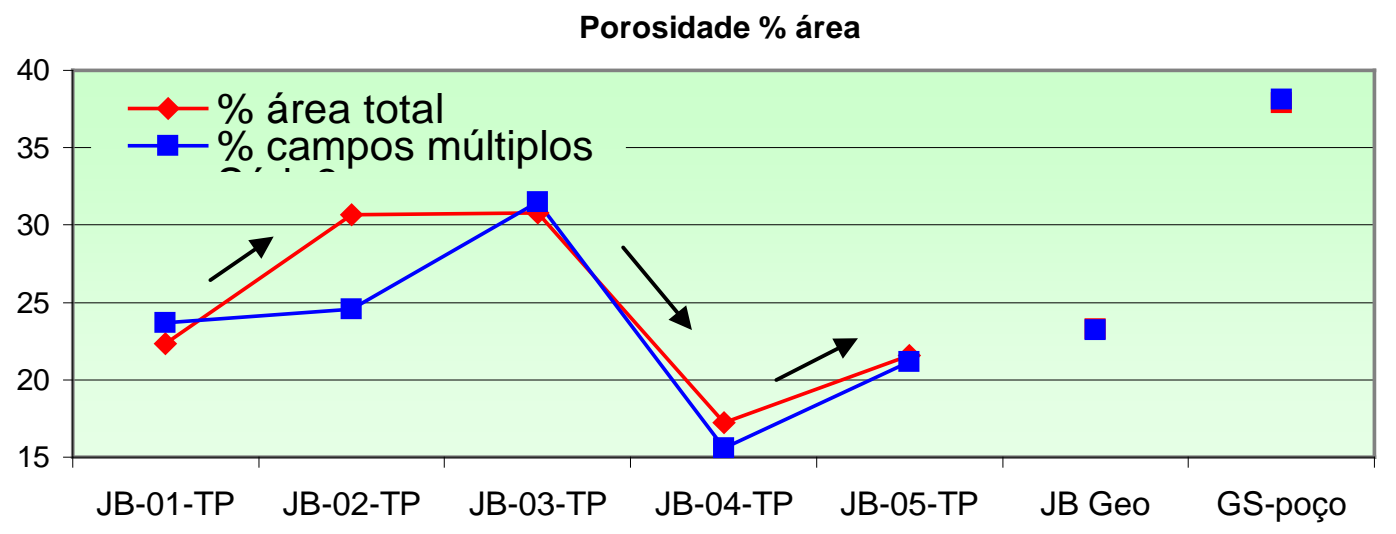

B

Figura 90 - Variação da porosidade medida em um quadro (vermelho) e a média de 28 quadros (azul). As setas indicam as tendências de variação dos dados obtidos. Lócus 1 (A), lócus 2 (B). 


\subsection{Microscopia eletrônica de varredura - MEV}

\section{Investigação morfológica}

Foram selecionados para estudo ao MEV cinco fragmentos da fração grossa examinada sob lupa, dos quais: dois torrões, um da fácies Lc coletado na base do lócus 2 e outro da fácies LA coletado no lócus 1; um clasto arredondado de lamito, representante dos "agregados lamíticos" do grupo de fragmentos siliciclásticos (Tabela 12); um fragmento interpretado como escória, representante do grupo dos "produtos de combustão" (Tabela 12); e um fragmento de concha revestida por fosfato, representante do grupo de "crostas fosfáticas" (Tabela 12).

As imagens confirmam a presença abrangente de fosfato, tanto nos torrões das fácies "funerárias" e "terra preta" (Figura 91 a Figura 93), quanto nas incrustações marromamareladas sobre conchas (Figura 94 a Figura 96) e demais elementos do arcabouço (conforme item 5.6). Estas incrustações caracterizam-se ao MEV por textura botrioidal, relacionada à precipitação de fosfato por processos intempéricos com forte influência de atividade microbiana (Gilinskaya et al., 2007; Holliday \& Gartner, 2007).

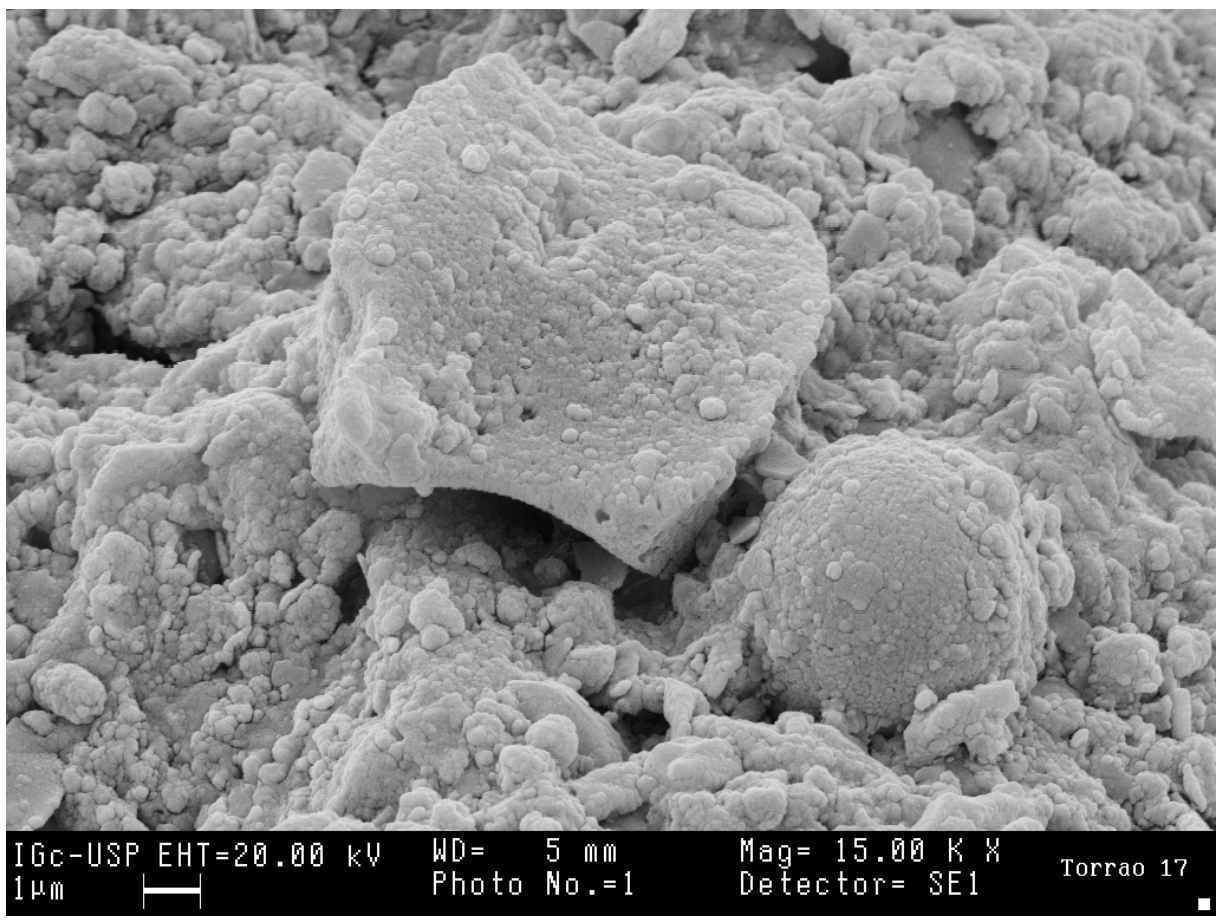

Figura $91-$ Microfragmentos fosfáticos em dois formatos distintos: placóide a tabular, à esquerda, e globular, à direita. Amostra de torrão da "terra preta", fácies LA (JB-17TP). 
Figura 92 - Detalhe do fragmento globular da figura anterior, mostrando a característica morfológica frambóide do fosfato. Nota-se que o formato globular é repetido em miniatura na superfície do esferóide maior. Amostra de torrão, da "terra preta" da fácies LA (JB-17-

TP).
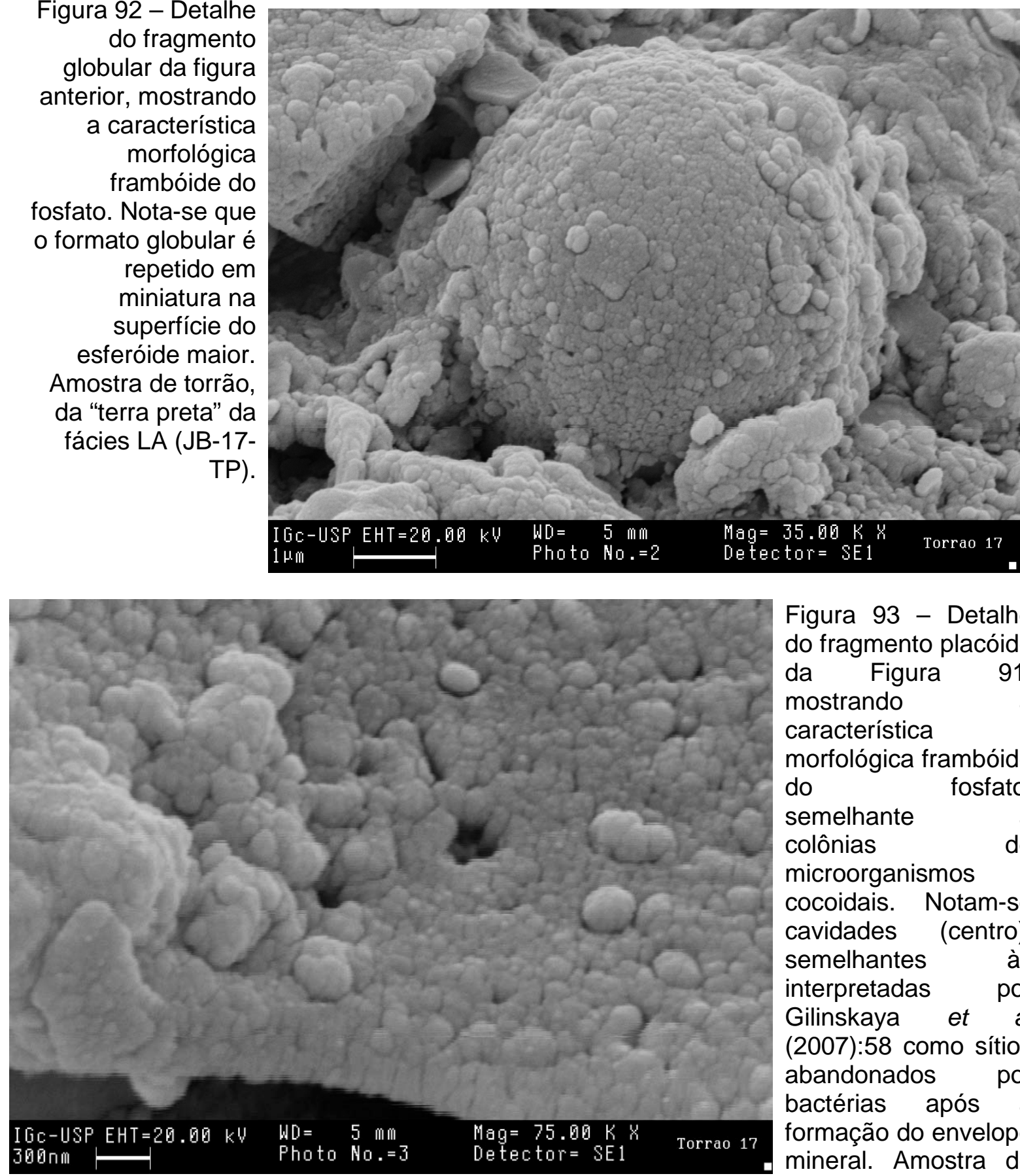

Figura 93 - Detalhe do fragmento placóide da Figura 91, mostrando a característica morfológica frambóide do fosfato, semelhante a colônias de microorganismos cocoidais. Notam-se cavidades (centro), semelhantes às interpretadas por Gilinskaya et al (2007):58 como sítios abandonados por bactérias após a formação do envelope mineral. Amostra de torrão, da "terra preta" da fácies LA (JB-17TP). 
Figura $94-$

Revestimento fosfático sobre concha. Notar textura botrioidal. Amostra de concha (provável Anomalocardia brasiliana) com incrustação marrom alaranjada de fosfato, selecionada aleatoriamente durante análise da fração grossa.

Amostra proveniente do sambaqui Jabuticabeira II.
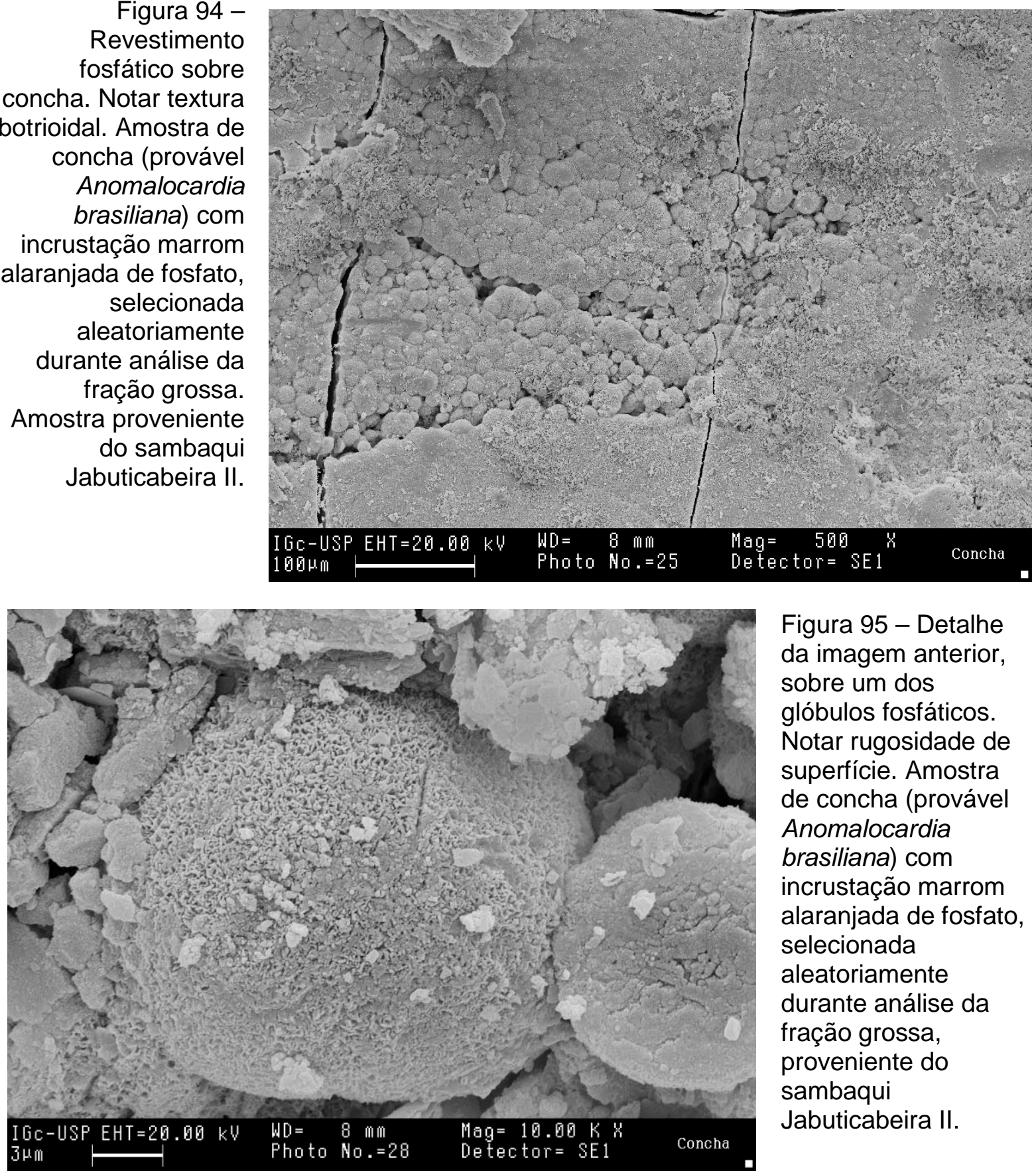

Figura 95 - Detalhe da imagem anterior, sobre um dos glóbulos fosfáticos. Notar rugosidade de superfície. Amostra de concha (provável Anomalocardia brasiliana) com incrustação marrom alaranjada de fosfato, selecionada aleatoriamente durante análise da fração grossa, proveniente do sambaqui Jabuticabeira II. 


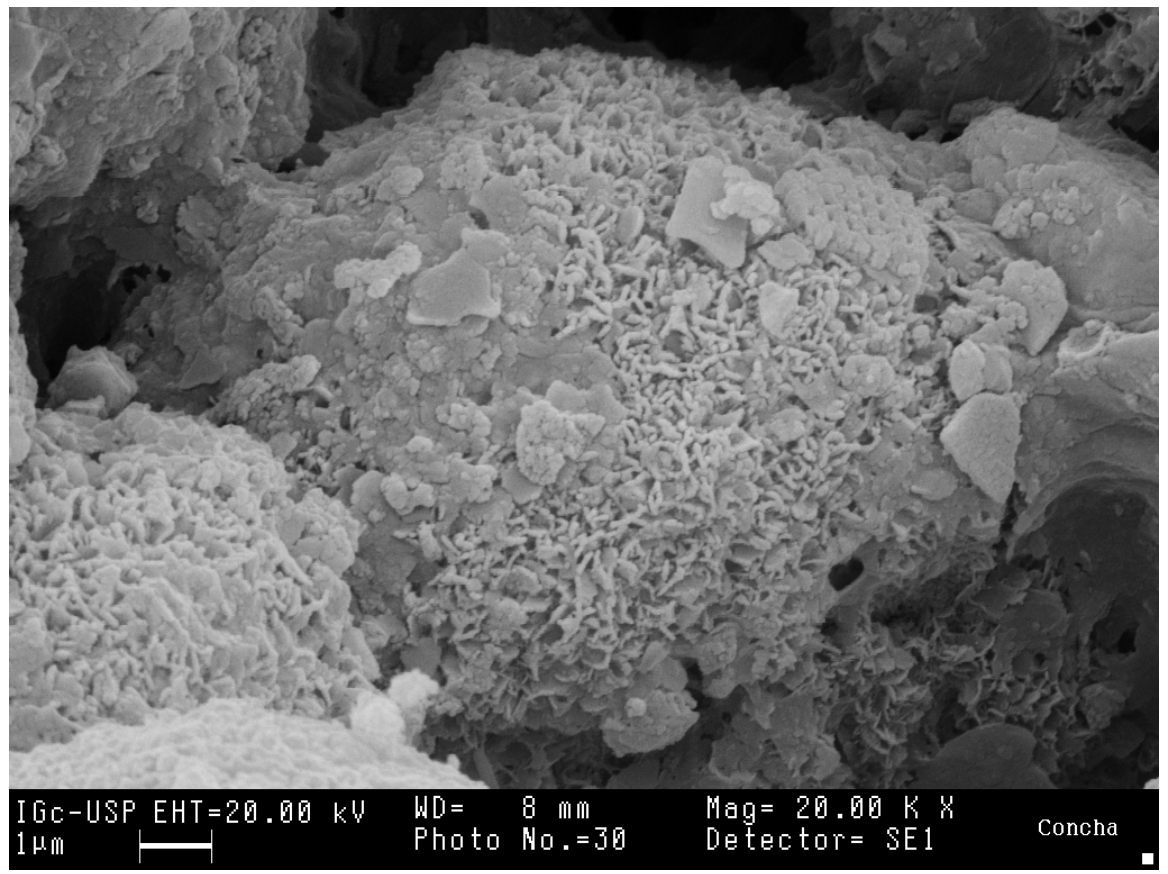

Figura 96 - Detalhe da Figura 94, sobre um dos glóbulos fosfáticos. Notar que a rugosidade de superfície corresponde a placas de minerais fosfáticos (canto inferior esquerdo) em trama predominantemente ortogonal à superfície do glóbulo. No canto superior direito, nota-se um fragmento de provável diatomácea. Amostra de concha (provável Anomalocardia brasiliana) com incrustação marrom alaranjada de fosfato, selecionada aleatoriamente durante análise da fração grossa, proveniente do sambaqui Jabuticabeira II.

Dentre os fragmentos analisados ao MEV, encontra-se a escória vítrea, material isótropo e translúcido observado com frequência durante o estudo micromorfológico e a análise da fração grossa sob lupa. A confirmação ao MEV desta identificação deu-se a partir da observação das cavidades coalescentes circulares e de paredes lisas que promovem aspecto "esponjoso", característico deste tipo de material (Figura 97 e Figura 98). O caráter de escória é reforçado ainda pelo registro, à microanálise química por EDS, de $\mathrm{Si}, \mathrm{Ca}, \mathrm{Al}, \mathrm{Na}$, $\mathrm{K}$ e Mg (Figura 99), elementos comumente encontrados na mineralogia dos produtos de combustão em contexto arqueológico (Schiegl et al., 1996:768) e coerentes com a composição de tecidos vegetais (Canti, 2003).

A origem da escória vítrea associa-se à fusão da opala constituinte de fitólitos (Gebhardt \& Langohr, 1999). A atribuição desta fusão a fogueiras antrópicas é freqüente, porém ainda debatida. Divergências a respeito relacionam-se ao fato de a sílica dos fitólitos sofrer fusão somente acima de $1000{ }^{\circ} \mathrm{C}$ (Thy et al., 1995), temperatura dificilmente alcançada em fogueiras sem que haja injeção forçada de ar. Hipóteses alternativas evocam eventos de maiores dimensões, como incêndios em campos, provocados antropicamente, ou incidência de raios durante tempestades elétricas (Thy et al., 1995). 
Figura 97 - Aspecto esponjoso de escória silicosa, formado pela coalescência de bolhas gasosas. Amostra de escória proveniente do sambaqui Jabuticabeira II, selecionada aleatoriamente durante análise da fração grossa.
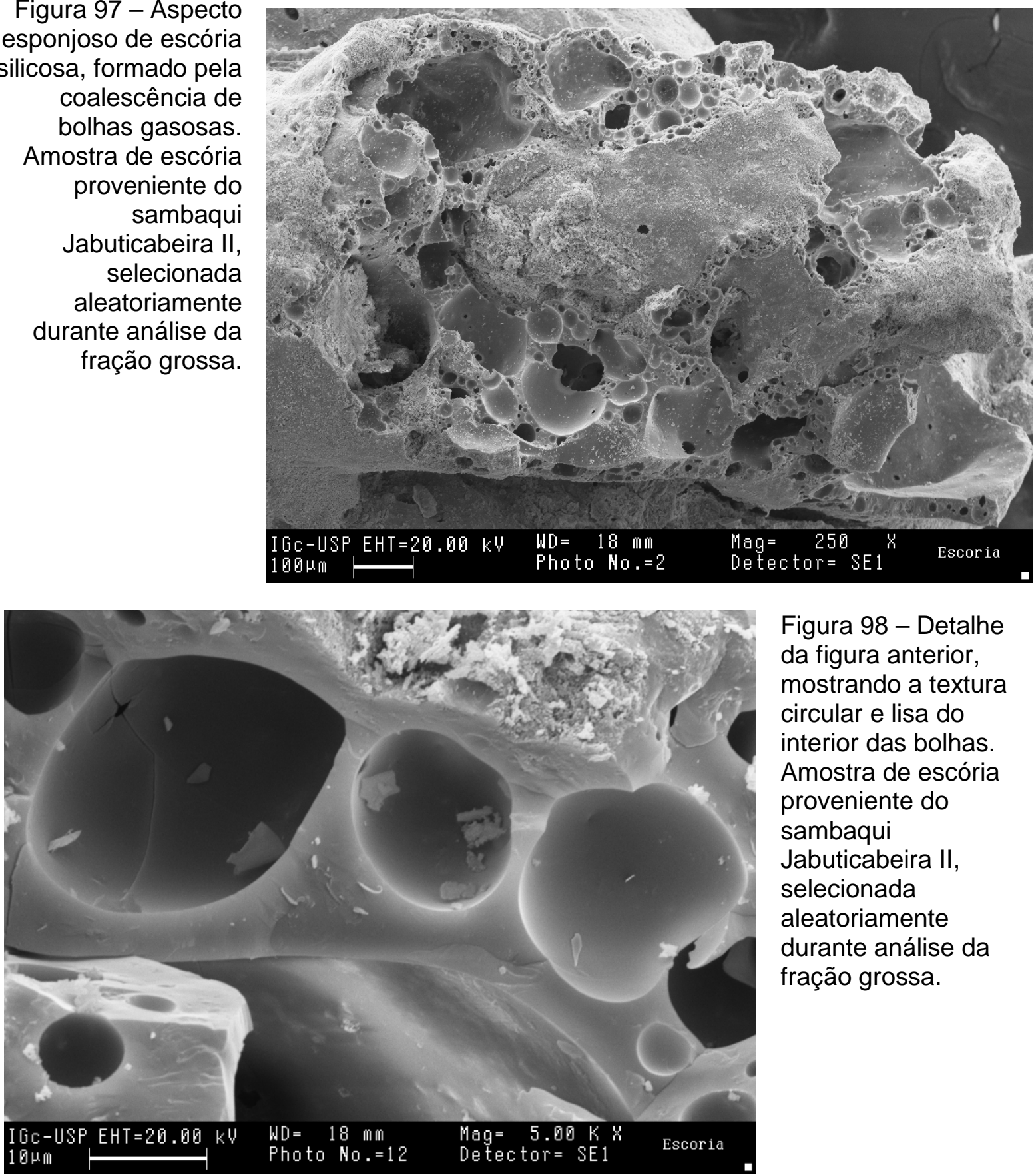

Figura 98 - Detalhe da figura anterior, mostrando a textura circular e lisa do interior das bolhas. Amostra de escória proveniente do sambaqui Jabuticabeira II, selecionada aleatoriamente durante análise da fração grossa.

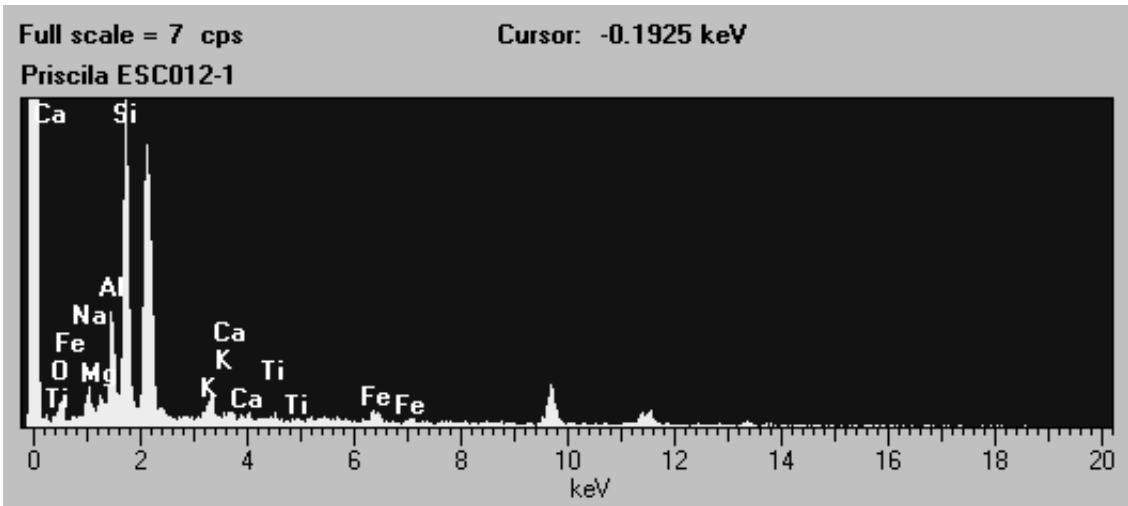

Figura 99 - EDS da amostra ilustrada na imagem anterior, indicando presença de $\mathrm{Si}, \mathrm{Ca}, \mathrm{Al}, \mathrm{Na}, \mathrm{Ke}$ $\mathrm{Mg}$ 
Os agregados lamíticos são fragmentos arredondados de coloração branca a cinza que compõem o grupo dos "fragmentos naturais", assim classificados durante a análise óptica da fração grossa à lupa. Alguns agregados lamíticos possuem diatomáceas com forma preservada, identificadas durante o estudo micromorfológico. Porém, a maioria dos agregados não possui conteúdo fossilífero distinguível sob microscópio óptico, apesar de apresentarem isotropia característica da opala, sílica criptocristalina que compõe as diatomáceas, associado à tessitura-b salpicada de filossilicatos.

Para dirimir as dúvidas em relação à composição dos agregados lamíticos que não possuem diatomáceas preservadas, coletou-se aleatoriamente um agregado aparentemente sem diatomáceas para ser observado ao MEV. As imagens mostram que se trata de agregado lamítico rico em diatomáceas fragmentadas (Figura 100) e, subordinadamente, inteiras (Figura 101).

Figura $100-$ Abundância de fragmentos de diatomáceas, exemplificados nas setas vermelhas, em meio a folhas de argilominerais aparentemente clásticos. Amostra de agregado lamítico proveniente do sambaqui Jabuticabeira II, selecionada aleatoriamente durante análise da fração grossa.

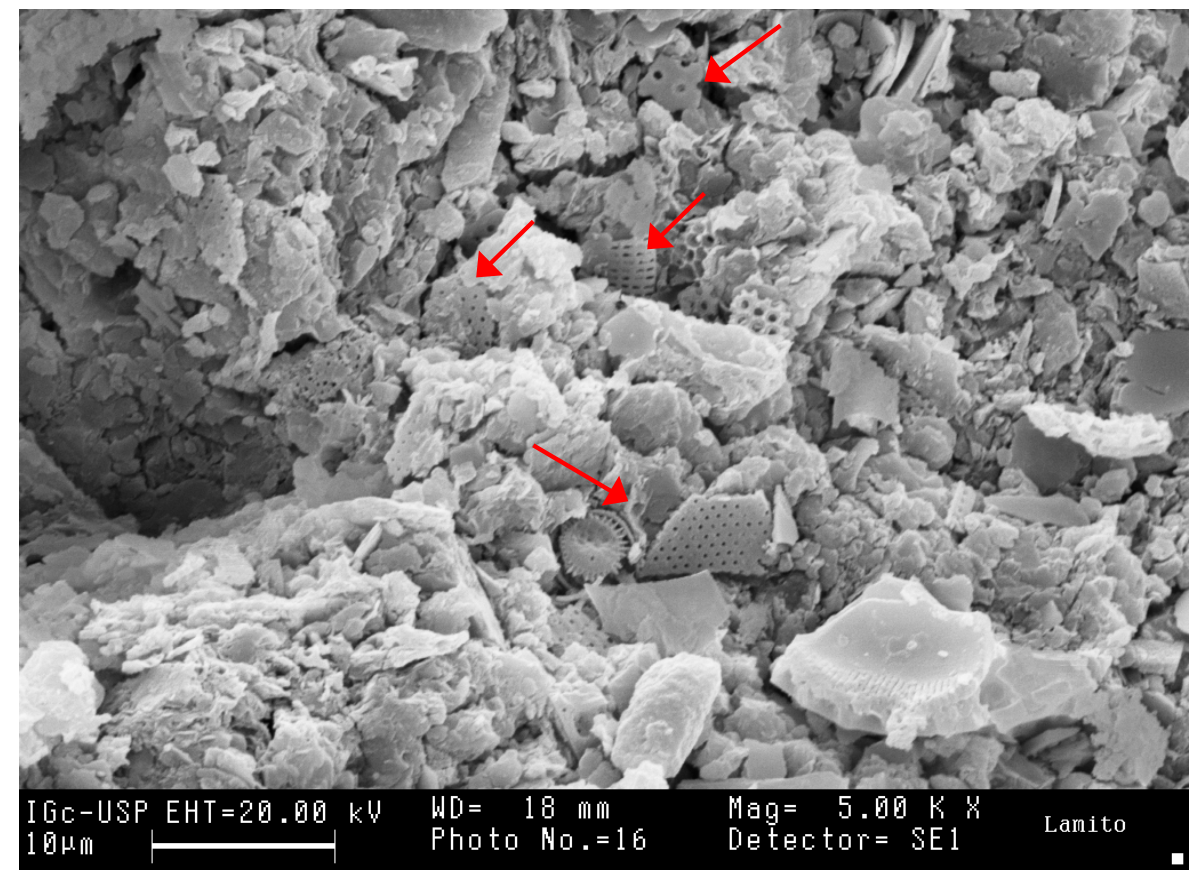




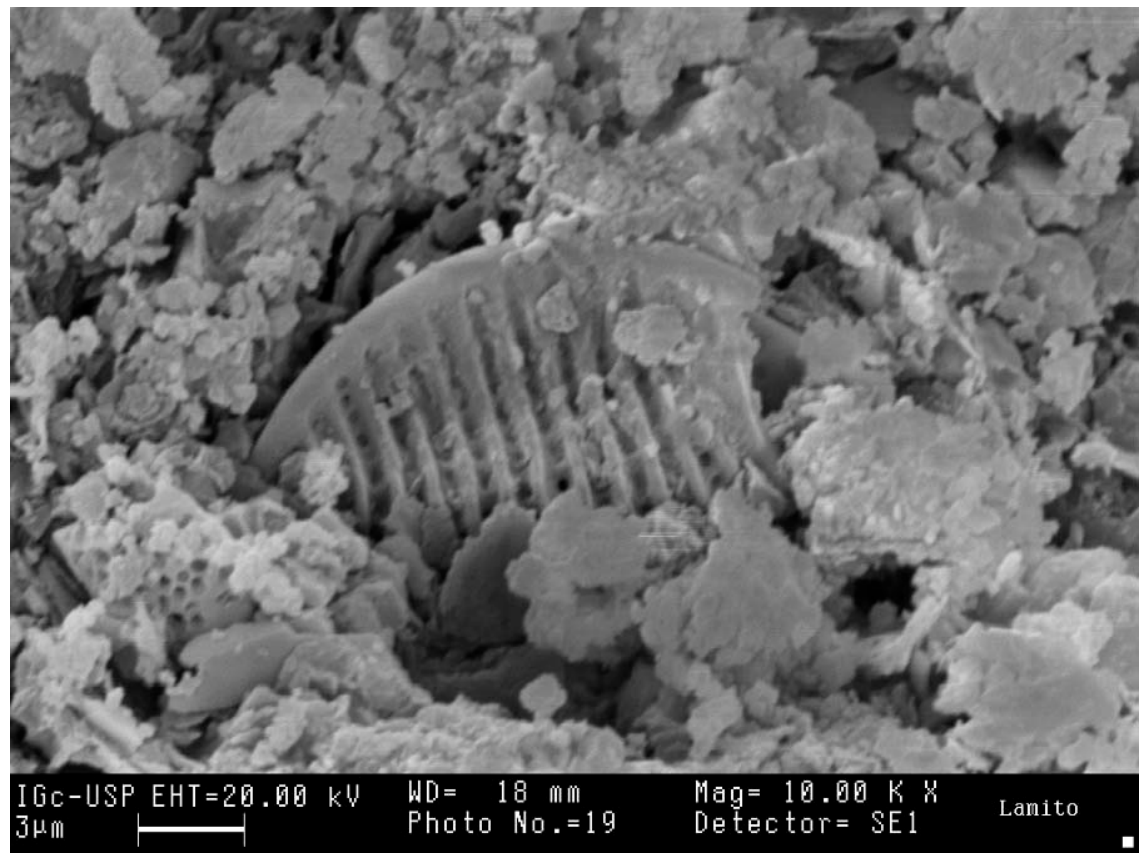

Figura 101 - Detalhe de diatomácea parcialmente preservada em meio a folhas de argilominerais com forma plana irregular. Amostra de agregado lamítico proveniente do sambaqui Jabuticabeira II, selecionada aleatoriamente durante análise da fração grossa.

Outros materiais foram encontrados durante as sessões de MEV como constituintes dos torrões de lâmina "funerária" (fácies Lc, amostra JB-01-TP). Entre eles, incluem-se fragmentos de ossos, diatomáceas morfologicamente preservadas e fitólitos.

\section{Mapeamento elementar}

Selecionaram-se duas lâminas de estudo micromorfológico para a realização de mapeamento elementar, por intensidade, de fósforo $(\mathrm{P})$ e cálcio $(\mathrm{Ca})$. O P estaria relacionado a ossos, a micromassa supostamente fosfática e a fragmentos/revestimentos fosfáticos, enquanto o Ca estaria ligado ao próprio fosfato (se de composição apatítica), e adicionalmente a conchas e micromassa carbonática (no Jabuticabeira II, Villagrán, 2008 associa a cinzas). As lâminas selecionadas originam-se do lócus 2 (JB-04-TP, amostra posicionada em seção colunar na Figura 34) e do lócus 1 (JB-09-TP, seção colunar da Figura 32). O critério para sua seleção foi a composição da micromassa, verificada sob microscópio óptico, onde a lâmina do lócus 2 mostra-se rica em micromassa carbonática (calcimicrita) e a do lócus 1, interpretada como rica em micromassa fosfática (massa isótropa). Para o mapeamento elementar por presença, pesquisaram-se nas mesmas lâminas, Ca, P, Al, Si e $\mathrm{K}$.

Os resultados confirmam a presença de $\mathrm{Ca}$, em maior intensidade que $\mathrm{P}$, na porção da micromassa da lâmina JB-04-TP (Figura 102a e b e Figura 103a e b) selecionada por conter carbonato micrítico. Villagrán (2008) conferiu a nomenclatura "fosfomicrita" (sensu Folk, 1959) ao fosfato criptocristalino da micromassa encontrada na "terra preta" do sambaqui 
Jabuticabeira II e atribuiu sua gênese ao intemperismo sofrido pelos restos arqueofaunísticos (ossos).

No mapeamento elementar por presença, na lâmina do lócus 1 (JB-09-TP), verificou-se que a micromassa da porção selecionada para análise é rica em Si (Figura 106 e Figura 108a), com presença importante de Al (Figura 104b e Figura 107b). Já P e Ca encontram-se restritos aos elementos do arcabouço (Figura 105a e b e Figura 109a e b), diferentemente do comportamento do Ca na lâmina JB-04-TP (Figura 102).

a)

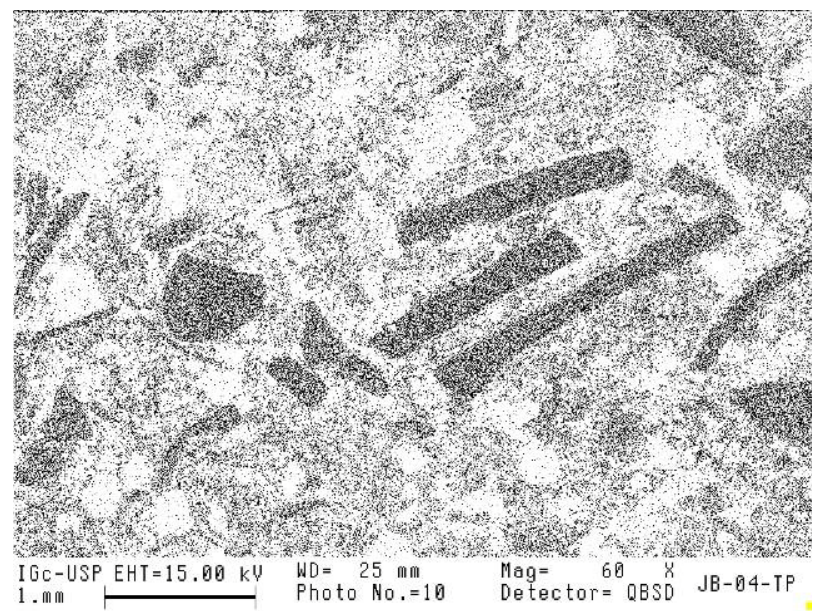

b)

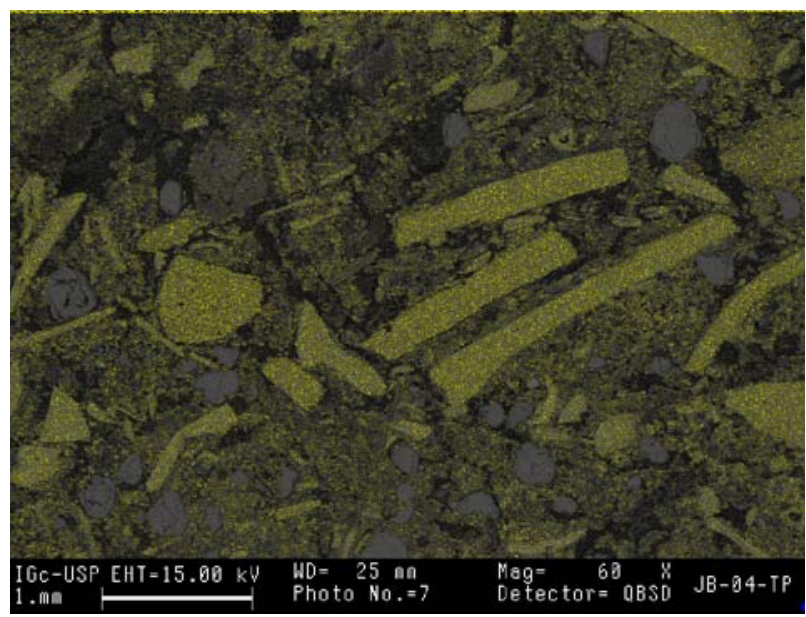

Figura 102 - Mapeamento elementar de Ca (pontículos pretos), sem (a) e com (b) sobreposição na imagem de elétrons retroespalhados. Notar abundância de Ca tanto na micromassa quanto nos fragmentos de concha de molusco no centro das imagens. Amostra em seção delgada JB-04-TP, lócus 2, Jabuticabeira II.

a)

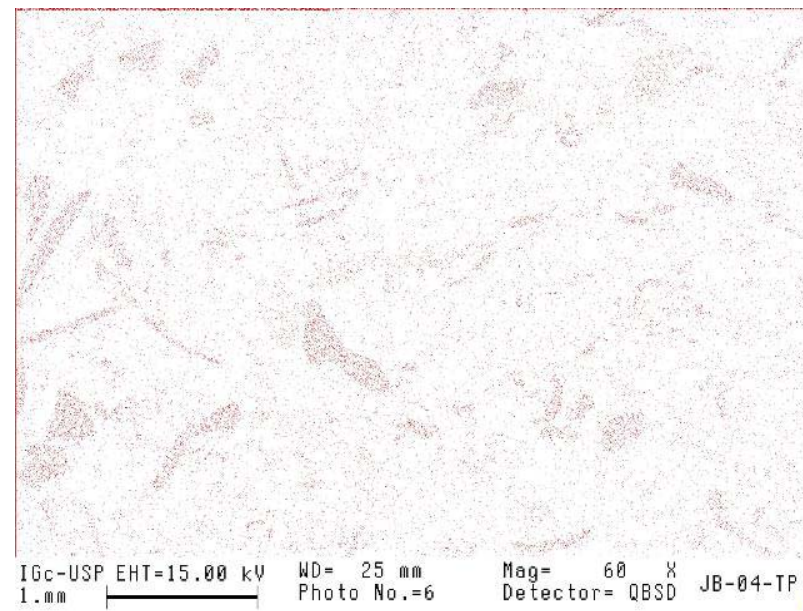

b)

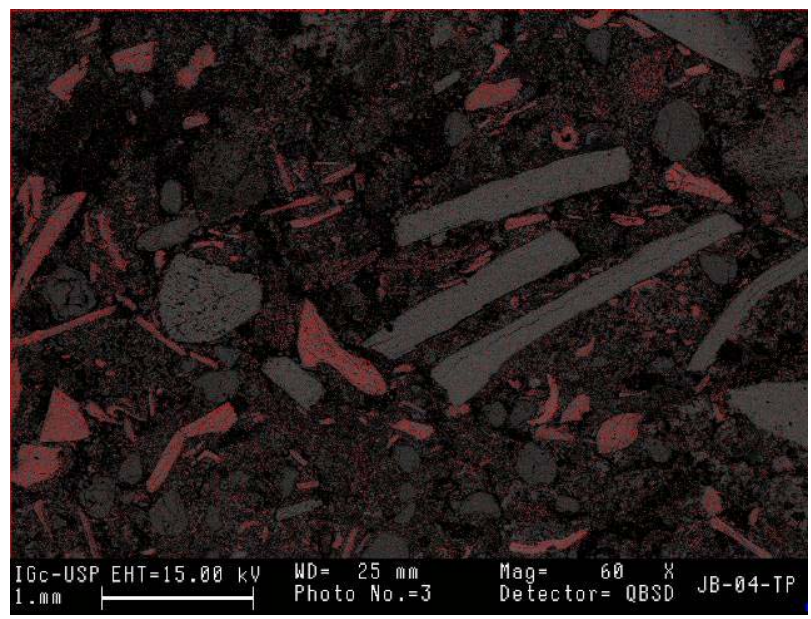

Figura 103 - Mapeamento elementar de P (pontículos vermelhos), sem (a) e com (b) sobreposição na imagem de elétrons retroespalhados. Notar que o $\mathrm{P}$ encontra-se restrito aos fragmentos de ossos, com pouca expressão na micromassa. Amostra em seção delgada JB-04-TP, lócus 2, Jabuticabeira II. 
a)

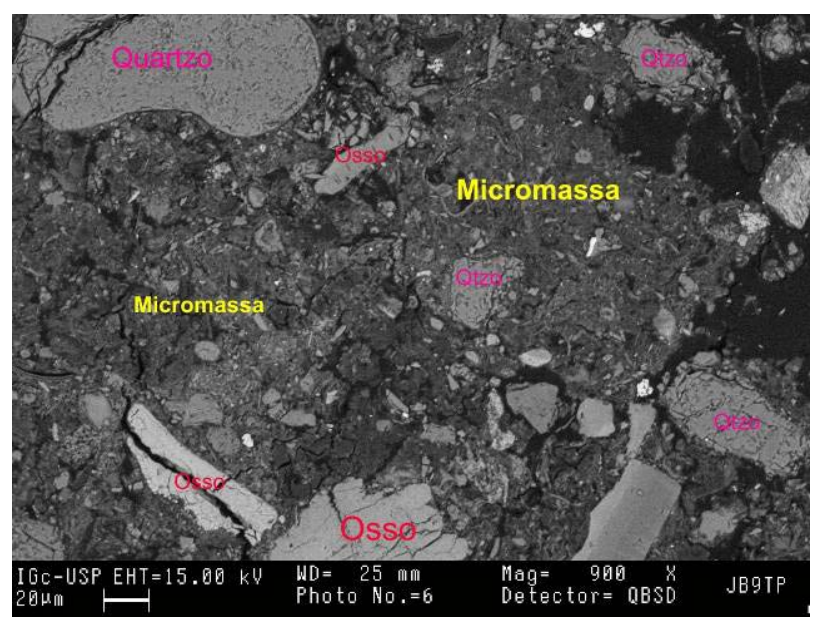

b)

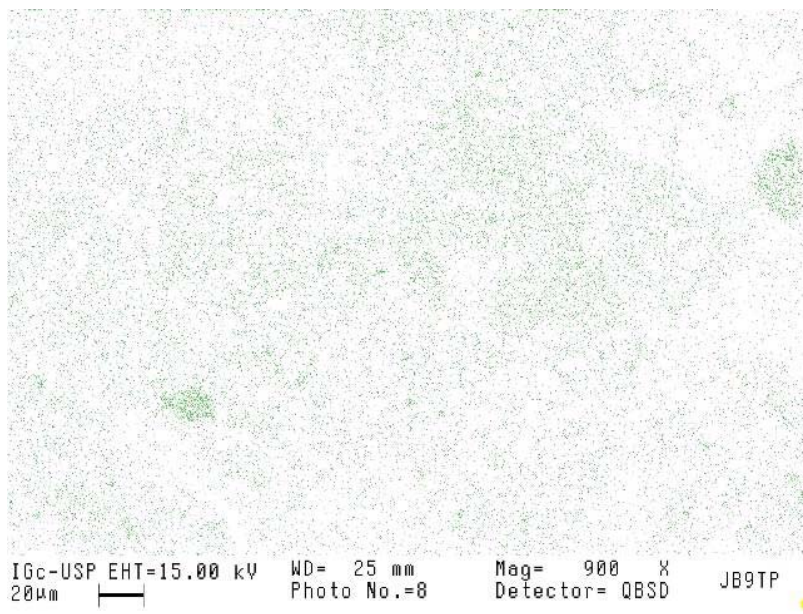

Figura 104 - Mapeamento elementar por presença. Imagem de elétrons retroespalhados (a) e mapeamento elementar por presença de Al (b: pontículos verdes). Os agrupamentos de pontículos verdes na imagem b) delineam fragmentos de material rico em filossilicatos, classificado como "lamito". Amostra em seção delgada JB-09-TP, lócus 1, Jabuticabeira II.

a)

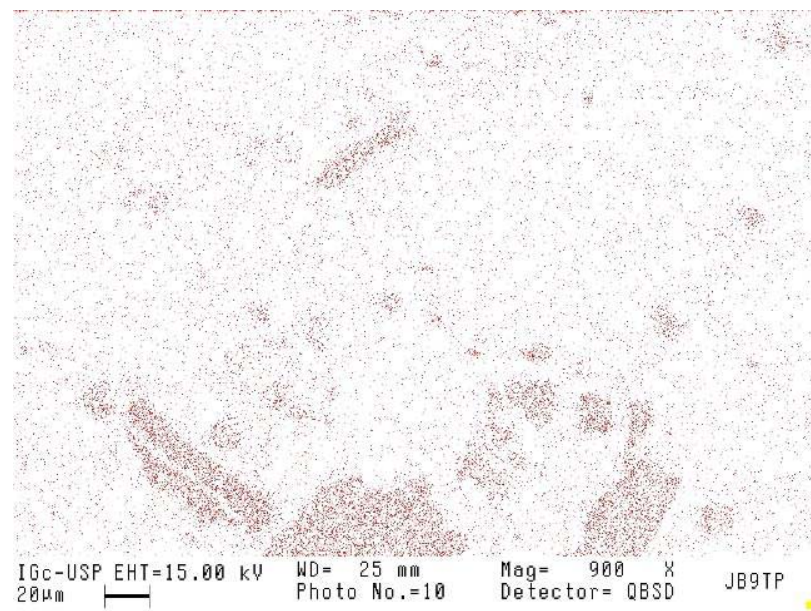

b)

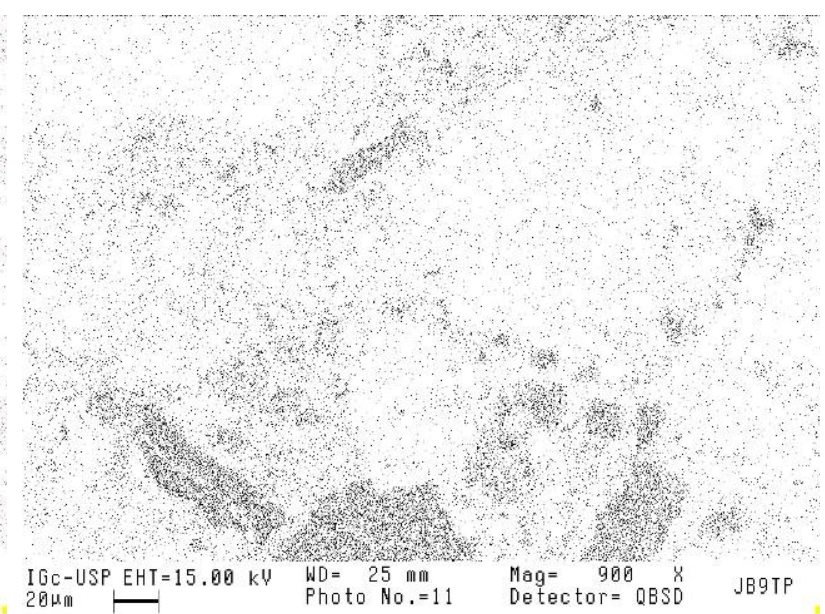

Figura 105 - Mapeamento elementar de P (pontículos vermelhos) (a), e mapeamento por presença de $\mathrm{Ca}(\mathrm{b})$. Notar que tanto o $\mathrm{P}$ e o $\mathrm{Ca}$ encontram-se restritos aos fragmentos de ossos, com pouca expressão na micromassa. Mesma imagem que a Figura 104a. Amostra em seção delgada JB-09-TP, lócus 1, Jabuticabeira II 


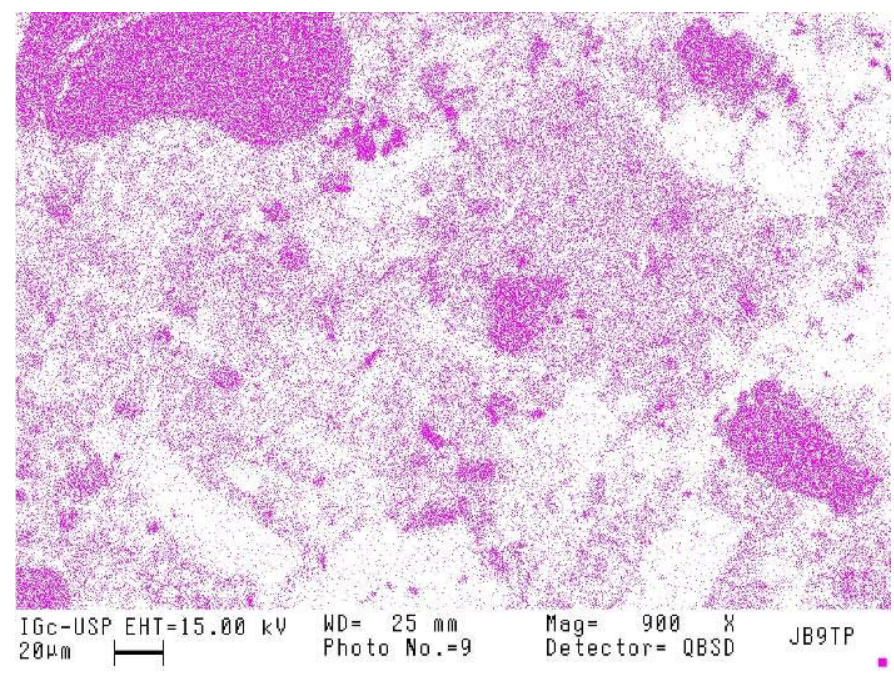

a)

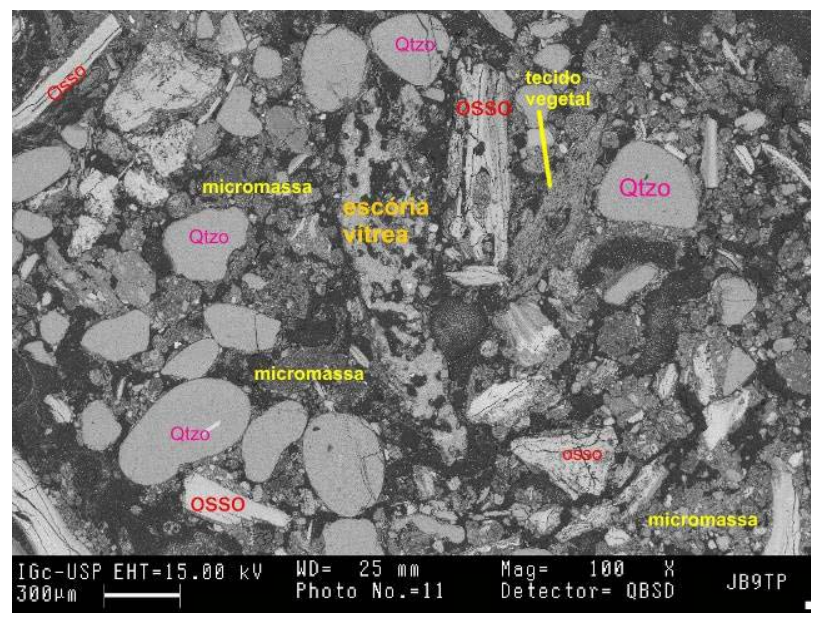

Figura 106 - Mapeamento elementar por presença de Si (pontículos magenta). Notar que além dos grãos de quartzo, a presença de Si na matriz é expressiva, comportamento oposto ao de $\mathrm{P}$ e $\mathrm{Ca}$ (figuras anteriores). Mesma imagem que a Figura 104a. Amostra em seção delgada JB-09-TP, lócus 1 , Jabuticabeira II.

Figura 107 - Mapeamento elementar por presença. Imagem de elétrons retroespalhados (a) e mapeamento elementar por presença de Al (b: pontículos verdes). Os agrupamentos de pontículos verdes na figura $b$ delineam fragmentos de material rico em filossilicatos, designado como "lamito" (canto superior esquerdo) e, no centro da imagem, presença de Al delineando discretamente um fragmento de escória vítrea. Amostra em seção delgada JB-09-TP, lócus 1, Jabuticabeira II. 
a)

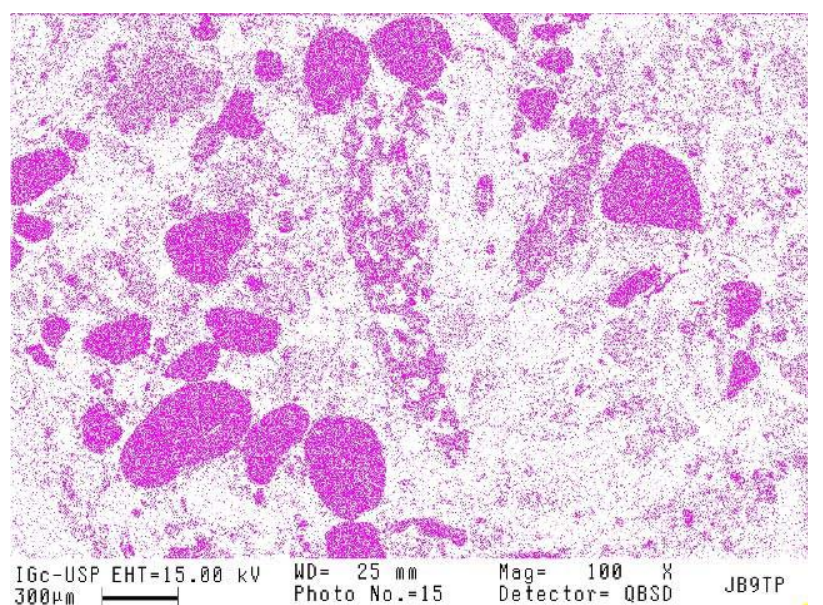

b)

Figura 108 - Mapeamento elementar por presença de Si (pontículos magenta) (a), e de K (b) (pontículos marrons). Notar que o Si possui presença importante tanto na micromassa quanto nos elementos do arcabouço, inclusive na escória vítrea (no centro da imagem a). Já o K possui comportamento semelhante ao Al (Figura 107b). Amostra em seção delgada JB-09-TP, lócus 1, Jabuticabeira II.

a)

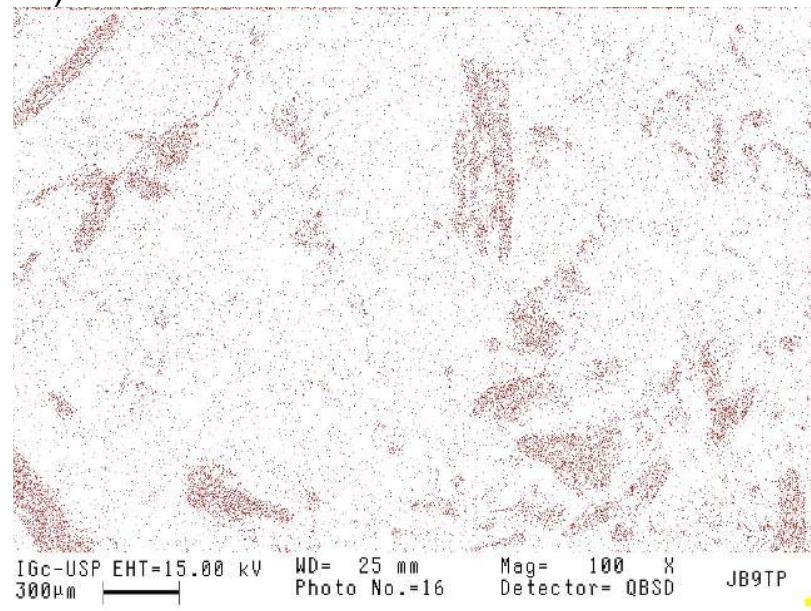

b)

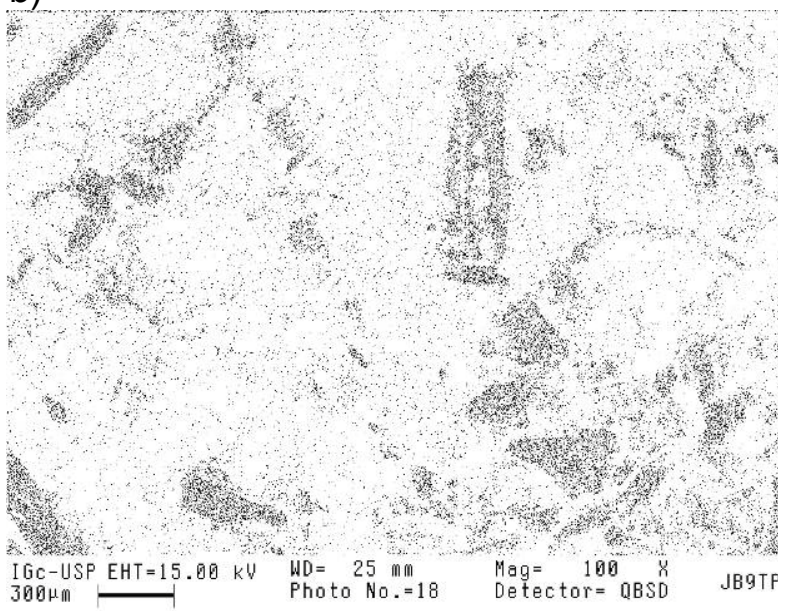

Figura 109 - Mapeamento elementar por presença de P (a) (pontículos vermelhos) e Ca (b) (pontículos pretos). Notar que ambos os padrões de distribuição elementar concentram-se nos elementos do arcabouço e possuem distribuição muito distinta em relação ao Si (Figura 108a). Mesma imagem que a Figura 107a. Amostra em seção delgada JB-09-TP, lócus 1, Jabuticabeira II.

Al e K possuem distribuições espaciais semelhantes, associadas a fragmento lamítico rico em diatomáceas e, discretamente, a grão de escória vítrea (Figura 107b e Figura 108b). A associação destes dois tipos de grãos aos mesmos elementos químicos permite sugerirIhes origem comum, a partir da alteração térmica de fitólitos e diatomáceas (ver Figura 78b, Figura 97 a Figura 101).

A presença do Si abrange tanto componentes silicosos do arcabouço (grãos de quartzo, lamito e escória vítrea) como a micromassa da matriz. Este elemento distribui-se de 
maneira distinta, e muitas vezes antagônica, a Ca e, principalmente, a P. Estes dois últimos elementos, por sua vez, ocorrem comumente associados na maioria dos componentes do arcabouço (ossos principalmente), exceto na matriz calcimicrítica, onde Ca ocorre de forma abrangente compondo a micromassa (Figura 102). Nesta situação, a presença de Ca na micromassa é interpretada como produto da substituição de óxido de cálcio por carbonato de cálcio, sendo o primeiro produzido pela calcinação do oxalato de cálcio presente em vegetais.

A presença do Si como principal componente da micromassa pode ser atribuída a abundância de fitólitos, morfologicamente indistintos em seção delgada, porém observados em montagem de grãos imersos em meio com índice de refração conhecido.

\subsection{Isotopia de carbono e nitrogênio: $\delta^{13} \mathrm{C}$ e $\delta^{15} \mathrm{~N}$}

O fracionamento isotópico via metabolismo biológico do carbono (C), especialmente por plantas e algas, e de $\mathrm{N}$, principalmente por animais, fornece informações a respeito da origem da matéria orgânica. Estas informações são especialmente interessantes quando o objeto de estudo são sistemas deposicionais quaternários com sedimentos orgânicos onde o efeito da diagênese possa ser desprezado. Os depósitos paleolagunares e arqueológicos da região enquadram-se neste tipo de situação. Os sedimentos dos três sambaquis estudados e em particular os do Jabuticabeira II, onde as fácies de "terra preta" e "funerárias", ricas em vestígios orgânicos, ocorrem de modo recorrente, são especialmente passíveis de estudo isotópico.

Os resultados de $\delta^{13} \mathrm{C}$ encontrados para as fácies de "terra preta" e "funerárias" do sambaqui Jabuticabeira II variam de $-23,94 \%$ a $-14,93 \%$ o (Figura 110), enquanto os valores de $\delta^{13} \mathrm{C}$ para a fácies areno-lamosa paleolagunar próxima ao sambaqui oscilam dentro de intervalo mais restrito, de $-25,89 \%$ a $-20,76 \%$ (Figura 111).

Nos pontos amostrados em sedimentos paleolagunares, observa-se tendência de decréscimo dos valores deס ${ }^{13} \mathrm{C}$, à medida que se aproxima da laguna atual (Garopaba do Sul). 

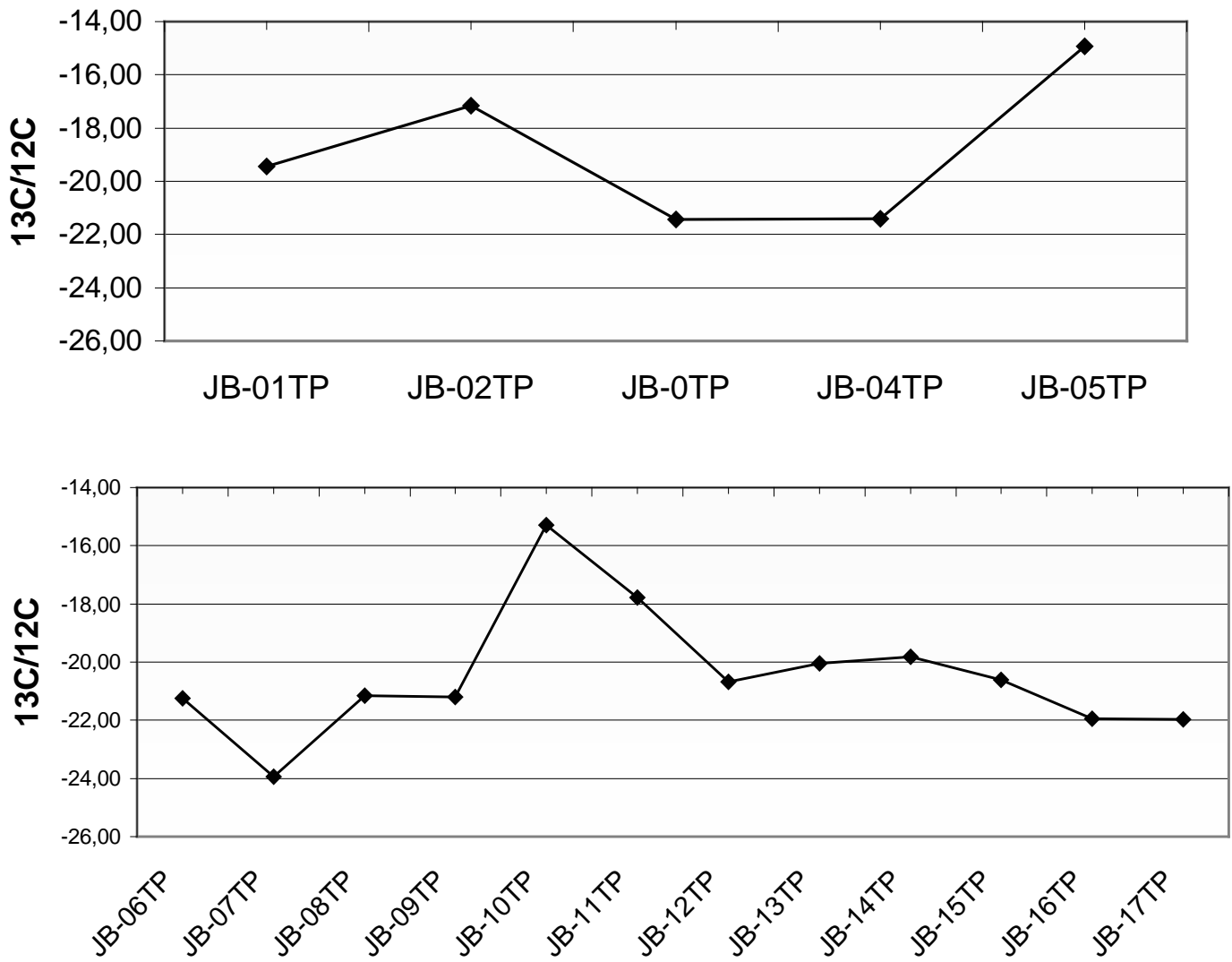

Figura 110 - Variação deס ${ }^{13} \mathrm{C}(13 \mathrm{C} / 12 \mathrm{C})$, em \%o (per mille), nas lâminas "funerárias" recorrentes (fácies Lc) do lócus 2 (gráfico superior) e do lócus 1 (gráfico inferior) do sambaqui Jabuticabeira II.

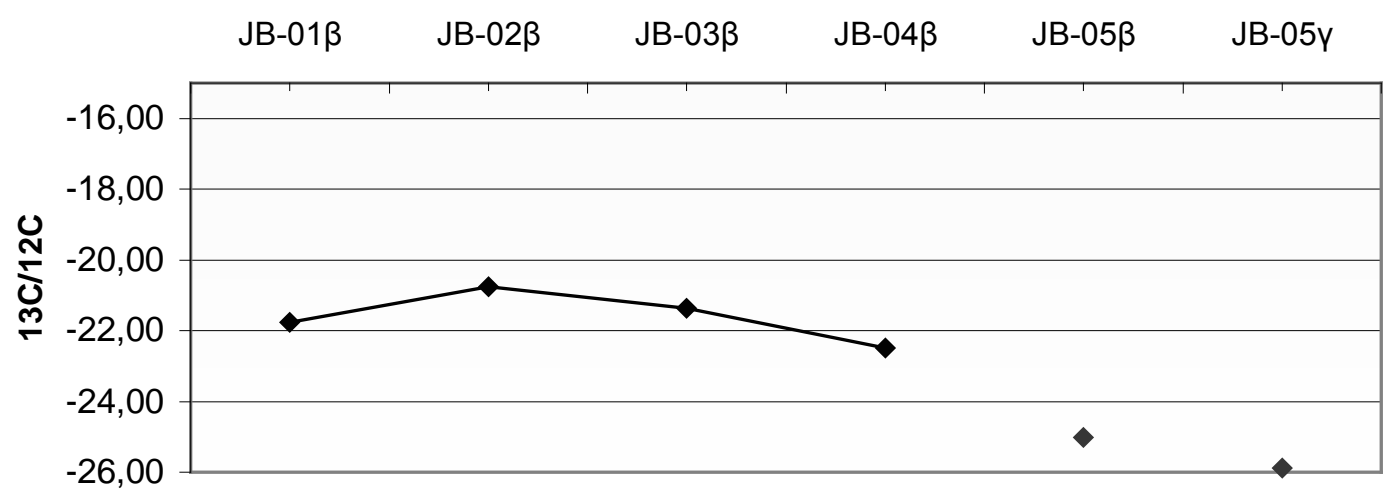

Figura 111 - Variação de $\delta^{13} \mathrm{C}(13 \mathrm{C} / 12 \mathrm{C})$, em \% (per mille), de sedimentos paleolagunares (fácies areno-lamosa) da área contígua ao sambaqui Jabuticabeira II, com localização apontada na Figura 24.

Os resultados de $\delta^{13} \mathrm{C}$ encontram-se entre os valores médios apontados por Meyers (1997) para plantas C3 (-27\%) e C4 (-14\%), com tendência da matéria orgânica paleolagunar para se aproximar mais dos valores de C3. 
O elevado coeficiente de correlação positiva (r), validado pelo nível de significância, entre carbono orgânico total (COT) e nitrogênio total ( $\mathrm{N}$ total) indica a natureza orgânica do N analisado (Figura 112), o que possibilita seu uso para interpretações acerca da origem da matéria orgânica (Hedges et al, 1986 apud Amaral, 2008).

O diagrama binário de $\delta^{13} \mathrm{C}$ em função da razão carbono/nitrogênio (C/N, Figura 113) permite reconhecer quatro conjuntos de amostras, com assinatura geoquímica compatível a: (1) carbono orgânico particulado marinho (COP-M); (2) mistura de COP-M e plantas C3 (seta preta inferior da Figura 113); (3) mistura de COP-M e plantas C4 (seta preta superior da Figura 113); e (4) plantas C3.

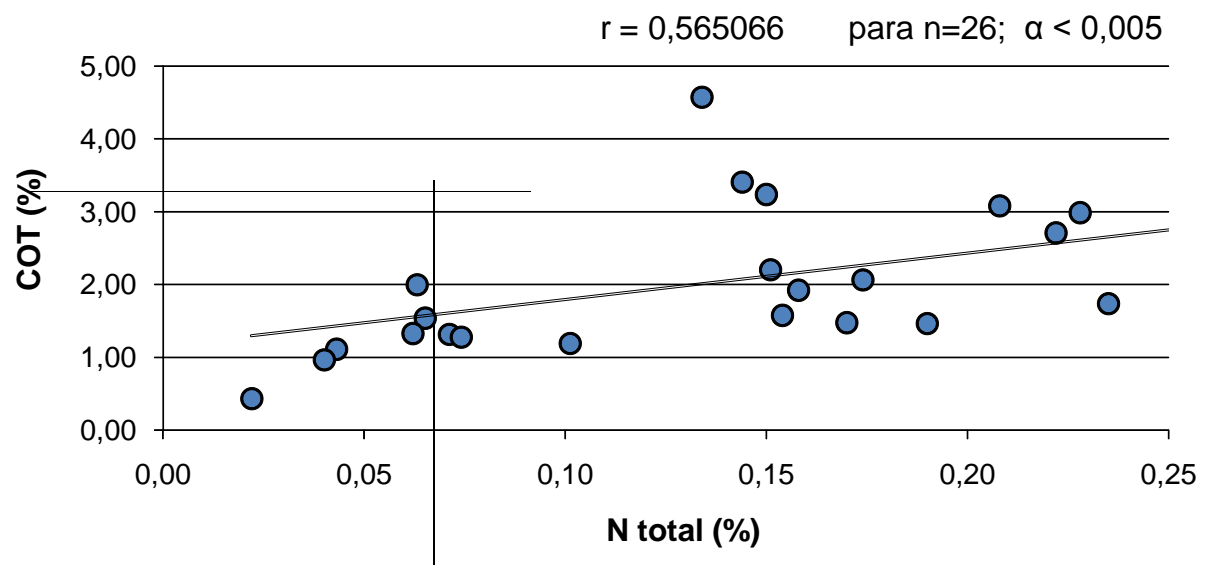

Figura 112 - Correlação linear entre valores de carbono orgânico total (COT) e nitrogênio total ( $\mathrm{N}$ total) validada pelo nível de significânciæ (teste $\mathrm{t}$ de Student); $\mathrm{n}=26$ corresponde ao espaço amostral. 


\section{Corg/Ntotal}

567891011121314151617181920212223242526272829303132333435

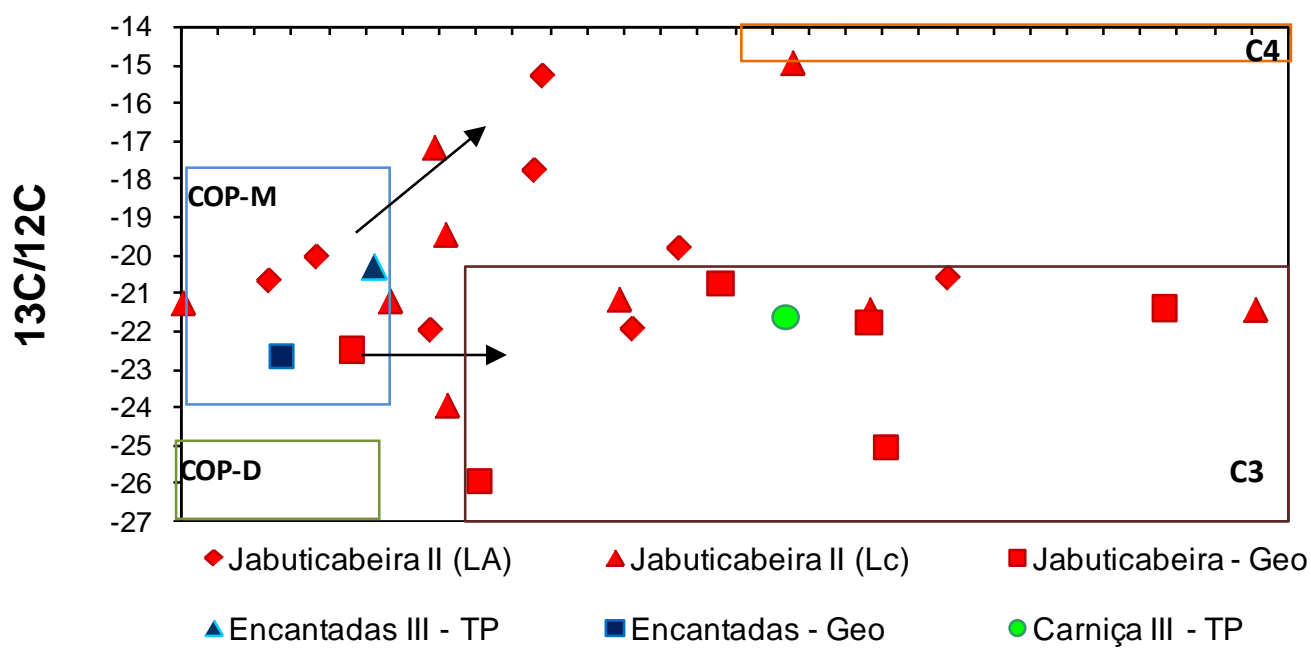

Figura 113 - Distribuição dos valores dळ ${ }^{13} \mathrm{C}$ em \%o (per mille) (13C/12C) e da razão carbono orgânico/nitrogênio total $\left(\mathrm{C}_{\text {org }} / \mathrm{N}_{\text {total }}\right)$ para a determinação da origem da matéria orgânica, utilizando os intervalos típicos de ambientes costeiros (polígonos com cores variadas) segundo Lamb et al. 2006. COP-D: carbono orgânico particulado de água doce; COP-M: carbono orgânico particulado marinho; C4: plantas de caminho metabólico tipo C4, geralmente associado a gramíneas; C3: plantas de caminho metabólico tipo C3, geralmente associado a elementos arbóreos.

O conjunto de valores correspondentes às amostras de matéria orgânica geogênica do entorno do sambaqui Jabuticabeira II (Jabuticabeira - Geo) encontra-se, em grande parte, no campo correspondente às plantas C3. Já a matéria orgânica oriunda das "terras pretas" (LC e LA) possui característica de mistura de fontes marinhas (COP-M) e C3 e, mais raramente, C4. A assinatura isotópica da matéria orgânica oriunda do sambaqui Encantada III, bem como a geogênica do seu entorno (símbolos em azul na Figura 113), é de carbono orgânico particulado marinho, com diferenciação entre matéria orgânica geogênica e antropogênica expressivamente menor que a encontrada para o sambaqui Jabuticabeira II e entorno. O mesmo poderia ser interpretado para a matéria orgânica presente na "terra preta" do sambaqui Carniça III, de característica francamente C3 (símbolo em verde, Figura 113), porém o dado referente ao depósito geogênico do entorno (próximo ao sambaqui Carniça I) apresentou valores anômalos de $\delta^{13} \mathrm{C}$ e $\mathrm{C} / \mathrm{N}$ e foi, portanto, descartado. Este valor anômalo $(41,08 \%$ ) pode ser interpretado como contaminação por carbonato (em vista de o valor de $\delta^{13} \mathrm{C}$ ser muito positivo).

Ao analisarem-se os valores de $\delta^{13} \mathrm{C}$ em conjunto com os de $\delta^{15} \mathrm{~N}$, através de diagrama binário de dispersão (Figura 114), nota-se diferenciação entre os conjuntos de valores do sambaqui Jabuticabeira II e dos sedimentos geogênicos locais. Esta diferenciação é 
determinada, sobretudo, pelos maiores valores de $\delta^{15} \mathrm{~N}(>10 \%)$ dos sedimentos oriundos das fácies Lc e LA ("funerária" e "terra preta") do sambaqui.

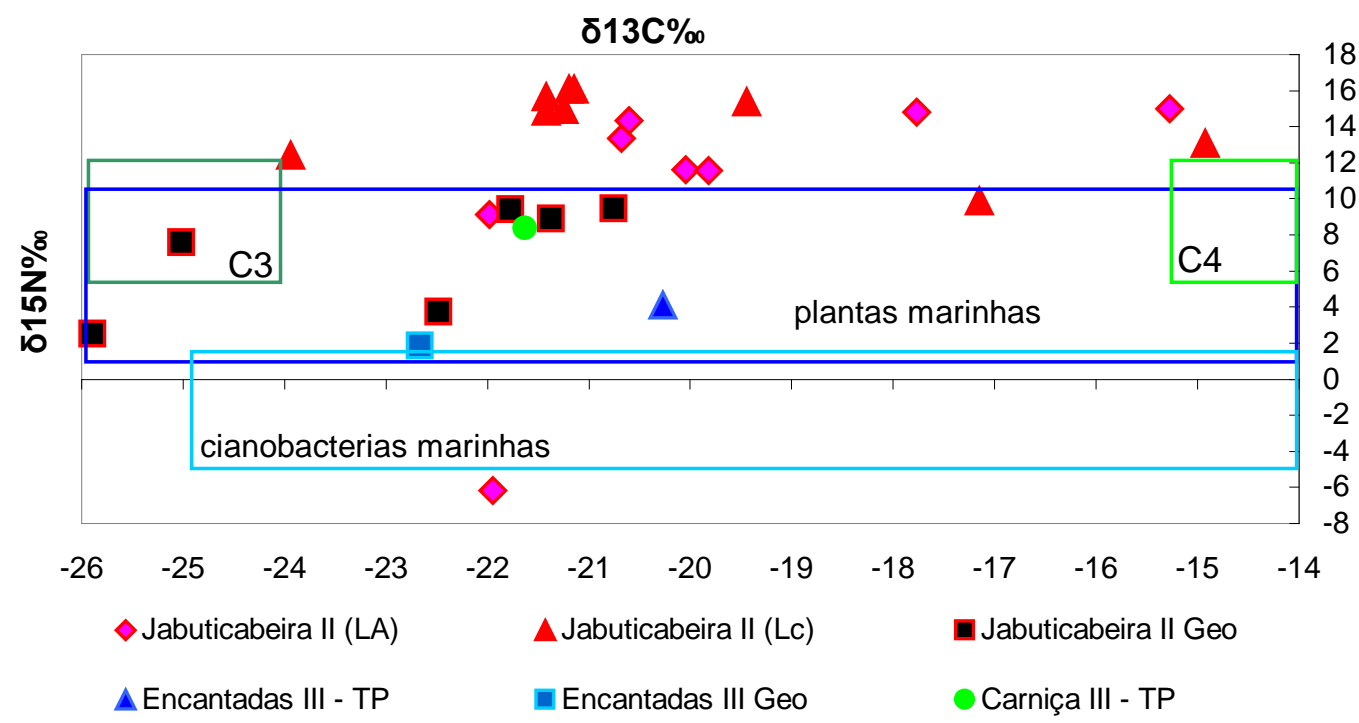

Figura 114 - Distribuição dos valores de $\delta^{13} \mathrm{C}(13 \mathrm{C} / 12 \mathrm{C})$ e $\delta^{15} \mathrm{~N}(15 \mathrm{~N} / 14 \mathrm{~N})$, expressos em \%o (per mille), obtidos em matéria orgânica das fácies Lc e LA ("funerárias" e "terra preta") (TP), dos sambaquis, e de sedimentos geogênicos identificados por "Geo". Campos de origem da matéria orgânica delimitados segundo White (2001).

Valores semelhantes de $\delta^{15} \mathrm{~N}$ foram encontrados por Shahack-Gross et al. (2008) e Shahack-Gross e Finkelstein (2008) em solos em contextos arqueológicos, onde valores de $\delta^{15} \mathrm{~N}$ acima de $9 \%$ correspondem a dejeto animal (dung) e valores abaixo desse limite às áreas de controle. Bogaard et al. (2007) apontam valores superiores a 10\% como indicativos de utilização de fertilizantes de origem animal (manuring) em contexto arqueológico. Outros estudos realizados fora de contexto arqueológico também sugerem intervalos de valores de $\delta^{15} \mathrm{~N}$ acima de $10 \%$ para solos, sedimentos e plantas, como oriundos de matéria orgânica animal (animal manure ou animal waste, segundo Kendall, 1998; natural fertilizers [manure], conforme Shibuya et al. 2006: 37; animal waste e sewer septic source, conforme Fogg, 2005, Figura 115). Valores acima de 9\% foram atribuídos por Commisso e Nelson (2006) como oriundos de restos de animais marinhos degradados em middens, na Groenlândia. 


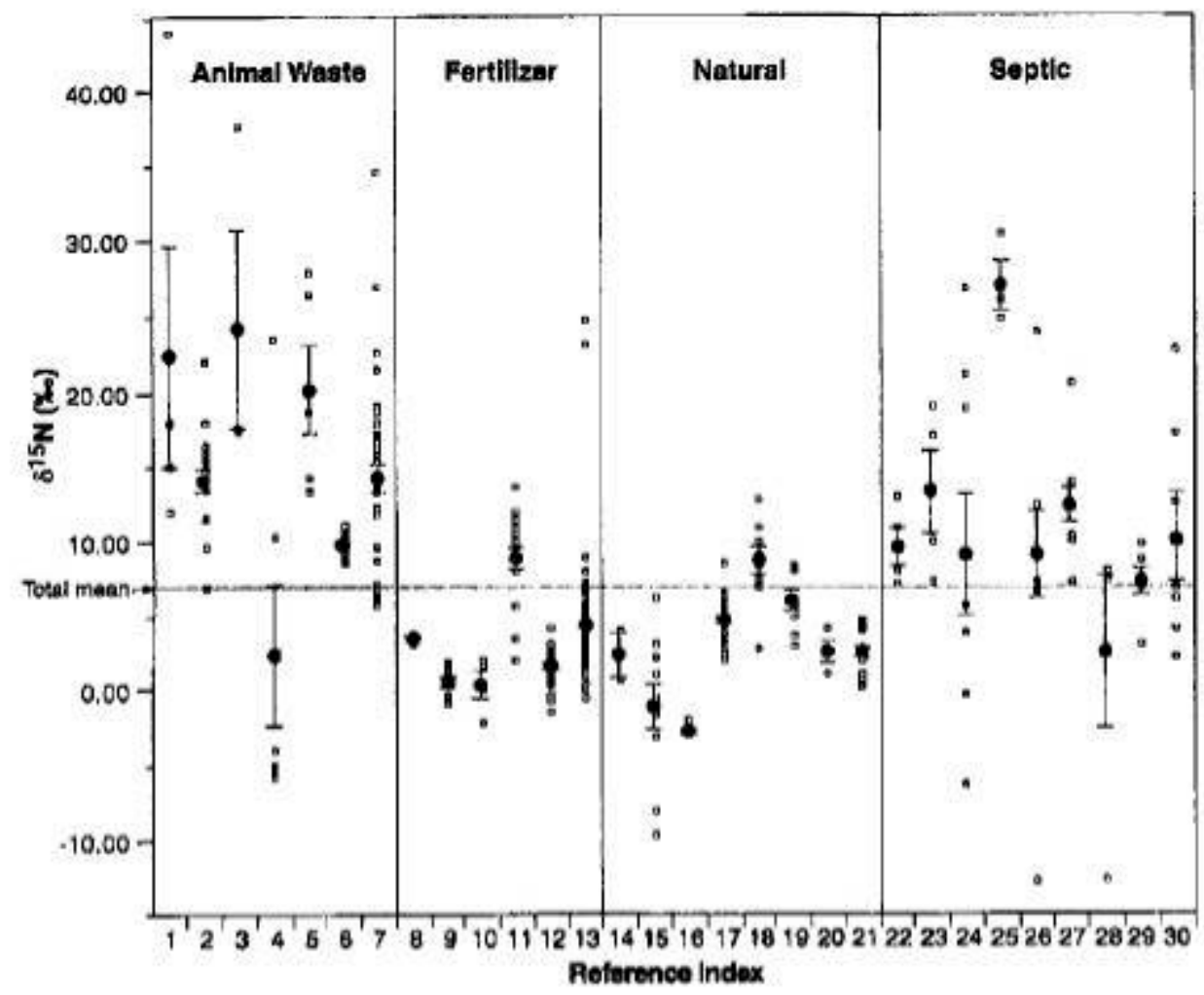

Figura 115 - Compilação de valores de $\delta^{15} \mathrm{~N}$ da literatura (quadro), modificado de Fogg et al (2005), onde se observa que grande parte dos valores acima de $10 \%$ correpondem a dejetos animais (animal waste) e fossas sépticas (septic). Fertilizer = fertilizantes manufaturados e Natural = matéria orgânica de solo "natural".

A teoria na qual os autores citados se basearam para explicar os valores elevados de $\delta^{15} \mathrm{~N}$ em dejetos animais é fundamentada no fracionamento isotópico pelo metabolismo de vertebrados, que descarta o nitrogênio leve $\left({ }^{14} \mathrm{~N}\right)$ através da urina, e concentra desta forma, o nitrogênio pesado $\left({ }^{15} \mathrm{~N}\right)$ nos tecidos e dejetos sólidos (Wolterink et al., 1979 apud Kendall, 1998). 


\subsection{Isotopia de carbono: datação ${ }^{14} \mathrm{C}$}

Foram datadas valvas de Anomalocardia brasiliana oriundas de dois depósitos paleolagunares distintos, um próximo ao sambaqui Jabuticabeira II e outro junto ao sambaqui Carniça I.

Pela descrição de fácies da trincheira JB-03 (item 5.1.1), as conchas paleolagunares amostradas junto ao sítio Jabuticabeira II correspondem a camada que materializa processos de dinâmica lagunar mais energética quando comparada com a fácies orgânica sotoposta (Figura 116). Desta forma, a escolha das valvas para datação foi feita de modo a selecionar material bioclástico o mais íntegro possível, que permitisse interpretar a data do carbonato como sendo a idade aproximada da deposição da camada de cascalho conchífero (item 4.2.8). A idade obtida (3698-4104 anos AP), projetada na curva de variação de NRM (Figura 117) de Angulo et al. (2006), indica paleonível cerca de $2 \mathrm{~m}$ acima do atual, e permite iinterpretar maior abrangência do corpo de água lagunar. A área, hoje de pântano e supramarés, corresponderia na época a fundo de laguna inter a inframarés, o que justificaria a dinâmica deposicional necessária para a deposição do cascalho bioclástico. 

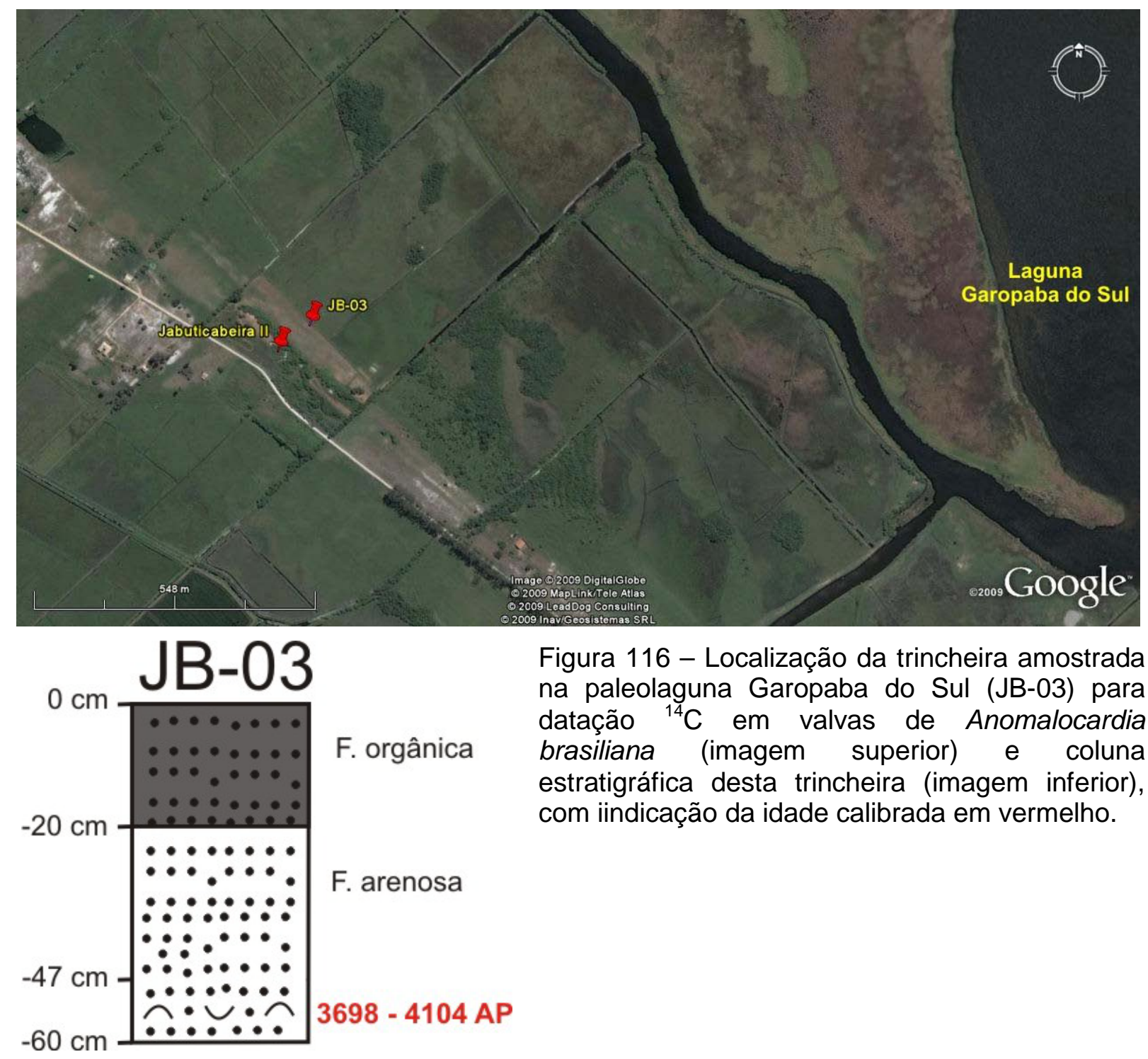

Figura 116 - Localização da trincheira amostrada na paleolaguna Garopaba do Sul (JB-03) para datação ${ }^{14} \mathrm{C}$ em valvas de Anomalocardia brasiliana (imagem superior) e coluna estratigráfica desta trincheira (imagem inferior), com iindicação da idade calibrada em vermelho.

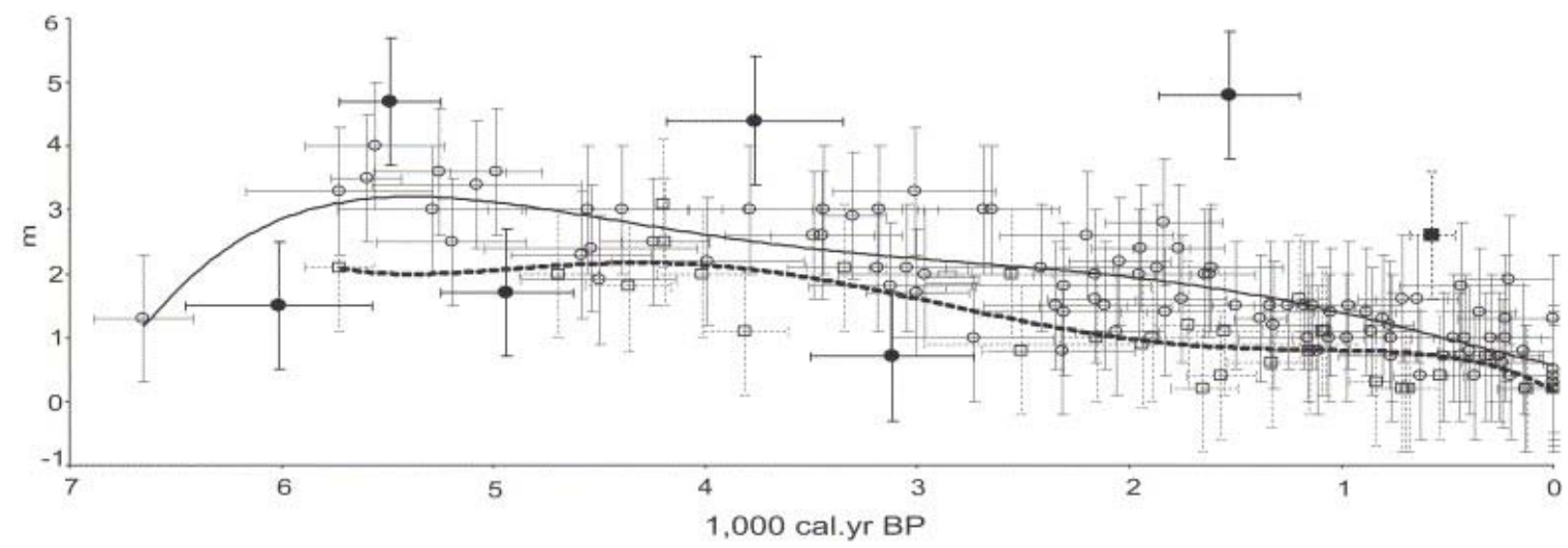

Figura 117 - Curvas de variação do NRM para a costa brasileira, baseadas em datações de carapaças fósseis de vermitídeos. A curva pontilhada, assim como os símbolos quadrados vazados, são específicos para o litoral sul de Santa Catarina. Compilado por Angulo et al. (2006). 
$\mathrm{Na}$ descrição de fácies da trincheira CV-01 (item 5.1.3), a camada de conchas amostrada para datação corresponde, por analogia às demais trincheiras estudadas, a um pulso mais energético da dinâmica paleolagunar, o qual teria permitido a deposição de cascalho bioclástico fragmentado, misturado a conchas inteiras, estas provavelmente pouco ou mesmo nada transportadas (utilizadas preferencialmente para datação). A presença de marcas de raízes (idade 2486-2881 anos AP) truncadas pelo nível conchífero (Figura 118), constitui indício de desenvolvimento de vegetação sob lâmina de água rasa ou inexistente (brejo de maré, pântano de maré ou marisma). Esta alternância entre camadas depositadas sob condições de subexposição e camadas conchíferas formadas sob pulsos de mais alta energia, pode indicar que se trata de uma paleomargem lagunar que evoluiu de fácies arenosa de mais alta energia a fácies areno-lamosa formada sob presença e influência da vegetação.
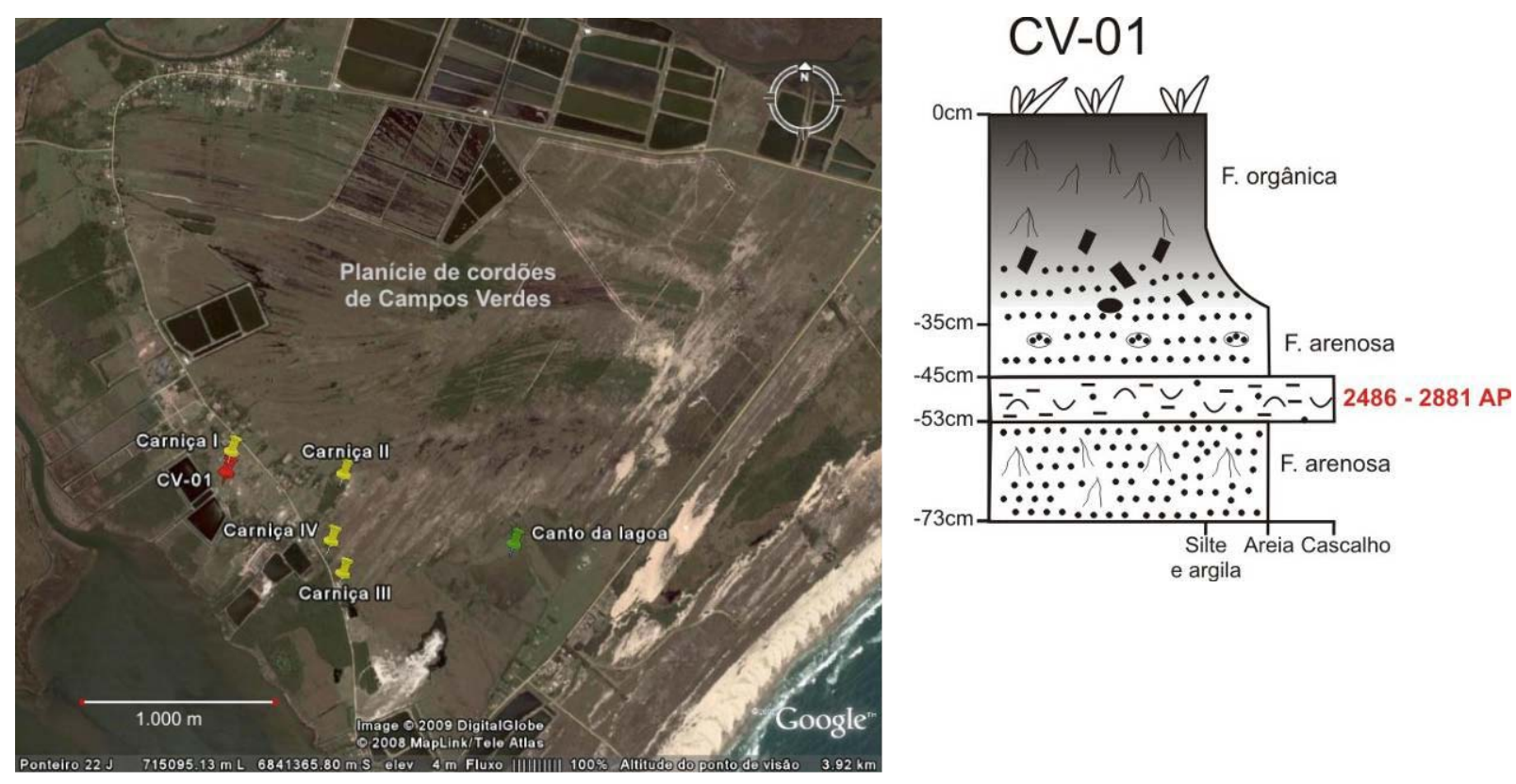

Figura 118 - Localização da trincheira amostrada (marcador vermelho) para datação 14C em valvas inteiras e preservadas de Anomalocardia brasiliana na imagem à esquerda e, coluna estratigráfica desta trincheira com a idade calibrada indicada em vermelho (2486-2881 anos AP) à direita.

Ambas as trincheiras amostradas para datação situam-se em contexto de paleomargem lagunar. O sítio Jabuticabeira II encontra-se sobre paleoalto topográfico sustentado por sedimentos eólicos da geração 2 que, supostamente, margeavam a paleolaguna na época da máxima inundação holocênica (Giannini, 1993). De modo semelhante, o sambaqui Carniça I assentava-se sobre possível paleopontal lagunar a retaguarda e transvesal ao sistema barra-barreira (Giannini 1993, Tanaka 2007, Tanaka et al. 2008, 2009). 
Nesta situação paleogeográfica hipotética, adimite-se como premissa que a população sambaquieira coletasse o material construtivo dos sambaquis em bancos de conchas na então margem da laguna, hoje materializada nas fácies bioclásticas observadas nas trincheiras de amostragem, ou em paleobancos da época. Admite-se também que a fácies bioclástica em questão deve ter migrado para o interior da laguna, à medida que o NRM declinava. A idade obtida para esta fácies bioclástica junto ao sítio Jabuticabeira II (trincheira JB-03, Figura 119) é cerca de 800 anos mais antiga que a base do sambaqui. Já a camada bioclástica próxima ao sítio Carniça I (trincheira CV-01, Figura 119) foi formada no último terço do intervalo de idades disponíveis para as conchas deste sambaqui. , assim, com base nas premissas adotadas sugere-se que as áreas de coleta das conchas utilizadas na construção dos sambaquis Jabuticabeira II e Carniça I situam-se entre a margem lagunar atual e os pontos amostrados.

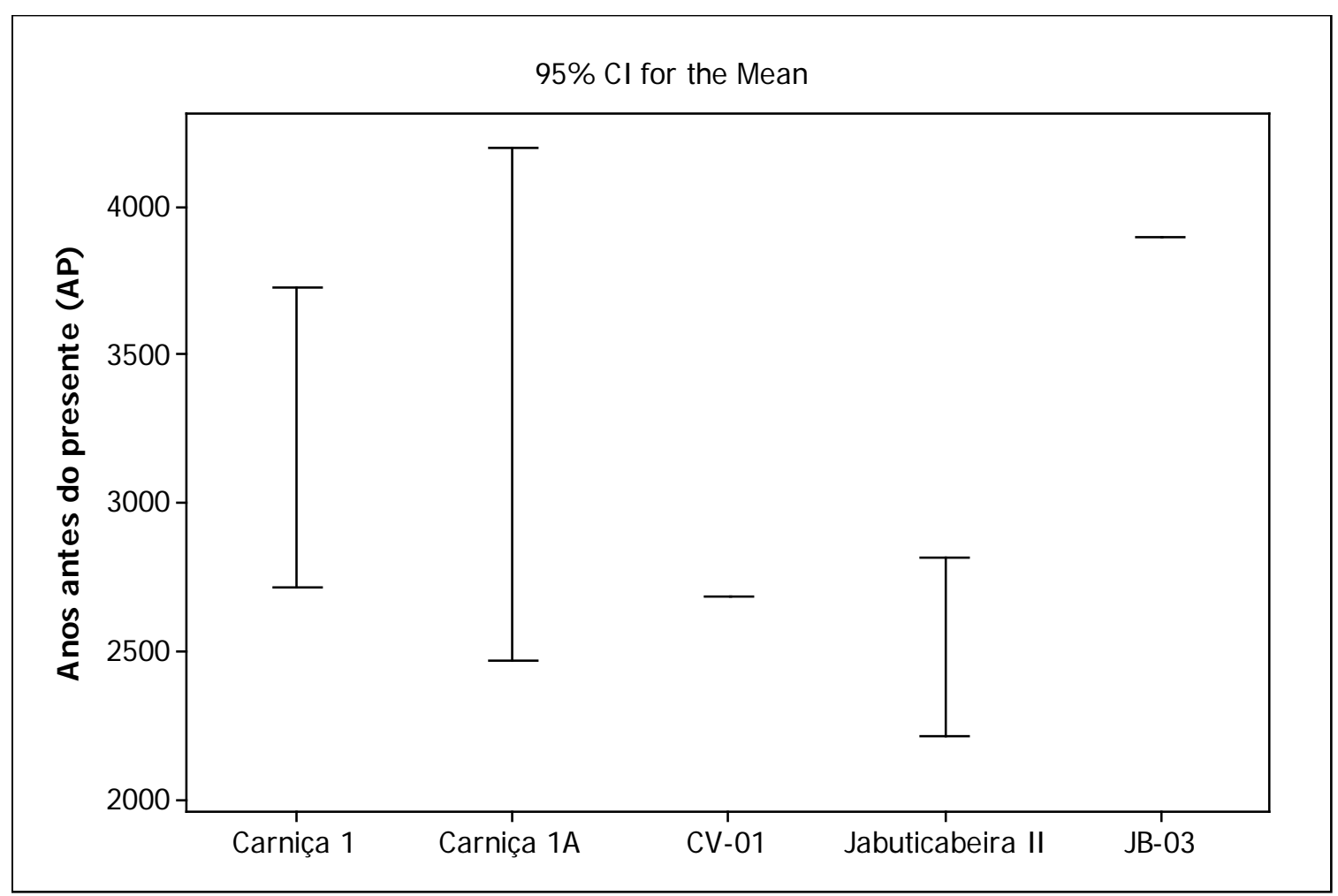

Figura 119 - Gráfico de intervalo das idades obtidas para conchas dos sambaquis Jabuticabeira II e Carniça I (Carniça 1 e 1A), compilado de DeBlasis et al (2005) e das conchas de trincheiras próximas a estes sambaquis (JB-03 e CV-01). As idades representadas correspondem ao intervalo médio de várias idades (Carniça 1, n=5; Carniça 1A, n=4; CV-01, n=1; Jabuticabeira II, n=8 e JB-03, $\mathrm{n}=1$ ) calibradas. 


\section{DISCUSSÃO DOS RESULTADOS}

\subsection{Análise de fácies}

Em uma primeira abordagem, o sambaqui Jabuticabeira II pode ser dividido em duas partes, o "pacote conchífero" (DeBlasis, 2005; Bendazzoli, 2007), na porção inferior, e a "terra preta", no topo. Esta simplicidade bipartite é apenas aparente. Estudos desenvolvidos com o objetivo de esmiuçar a estratigrafia deste sambaqui (Klökler, 2001; Bendazzoli, 2007; Klökler, 2008) ou, especificamente, da "terra preta" que o capeia (Villagrán, 2008), têm tornado evidente a complexidade estratigráfica de ambas as subdivisões.

Bendazzoli (2007) separou diferentes grupos de camadas do sítio Jabuticabeira II, com base em parâmetros tanto composicionais ("matriz de areia", "matriz de conchas" e "terra preta"), como estruturais ("camadas compactadas" e "laminares") ou mesmo interpretativos ("camada funerária"). Com base neste exercício de identificação de tipos de camadas, a autora estabeleceu uma série de relações estratigráficas entre eles. Merece destaque, entre estas relações, o fato de as "camadas funerárias" (equivalentes a fácies Lc nesta Dissetação), pertencentes ao "pacote conchífero", não se empilharem diretamente umas sobre as outras, mas ocorrerem interestratificadas com conchas e areia inconsolidadas. Assim, estas "camadas" apareceriam sempre associadas, em sucessão deposicional, às "camadas" ditas como do "grupo com matriz de conchas" (equivalentes às fácies conchíferas nesta Dissertação).

Mesmo sem uma aplicação formal do conceito de fácies, Bendazzoli (2007) e Klökler (2008) aplicaram a análise de fácies desde a delimitação inicial das unidades até seu agrupamento em associações. Estas associações serão tratadas aqui como associações de "camadas", a fim de se distinguirem das associações traçadas no âmbito da análise de fácies realizada deliberadamente neste trabalho.

As correlações e associações de camadas esboçadas por Klökler $(2001,2008)$ e Bendazzoli (2007) pressupõem relação genética definida entre "camadas funerárias" e conchíferas, como se as conchas servissem de cobertura para cada "camada funerária". Segundo as autoras, esta relação repete-se em ambos os lócus, e, interpretativamente, as camadas de conchas teriam a função de cobrir a "camada funerária", fechando assim um ciclo deposicional. Desta forma, a "camada funerária" (fácies Lc, neste trabalho) poderia ser considerada superfície delimitante de uma suposta associação de fácies, a qual se repetiria quase ritmicamente em grande parte do sambaqui. Esta associação de fácies representa 
portanto um ritmo ou ciclo construtivo do sambaqui, onde cada ciclo é interpretado como ritual de sepultamento (DeBlasis, 2005; Bendazzoli, 2007, Klökler, 2008).

De uma perspectiva diferente de Klökler $(2001,2008)$ e Bendazzoli (2007), as várias fácies descritivas do sambaqui Jabuticabeira II reconhecidas nesta Dissertação agrupam-se segundo três associações, da base para o topo: cascalho-lamosa, areno-lamosa e cascalhoarenosa (item 5.1). Cada uma destas associações contém um número variável de associações de camadas e lâminas (conchífera sobre "funerária") no sentido de Bendazzoli (2007) e Klökler (2008). Desse modo, tanto as associações de "camadas" daquelas autoras como as três associações de fácies enfatizadas neste trabalho podem ser consideradas associações de fácies e elementos arquitetônicos sensu Miall (1985), conforme descrito no item 3.2.4, só que em hieraquias diferentes. As associações de "camadas" de Bendazzoli (2007) e Klökler (2008) estariam contidas, em hierarquia menor, dentro das associações de fácies aqui consideradas.

A partir na análise de fácies executada, neste trabalho, para o sambaqui Jabuticabeira II, pode-se inferir que a associação entre fácies conchíferas e lâminas "funerárias" (fácies Lc), dentro do "pacote conchífero", representa a menor hierarquia de associação de fácies reconhecível, indicativa do processo construtivo básico do sambaqui durante a formação deste "pacote".

O significado deste processo construtivo básico, dentre infinitas outras possibilidades, tem sido atrelado a ritos funerários, em vista da grande concentração de sepultamentos neste sítio. Admitido esse modelo interpretativo, a fácies Lc pode ser a materialização de um processo cultural episódico de ritual funerário, cujos materiais (ossos de peixe queimados, restos de fogueira, artefatos líticos, fragmentos fosfáticos de origem antrópica e ossadas humanas) são componentes comuns a todas as recorrências desta fácies.

Pelo caráter recorrente, com boa continuidade lateral, e por representar o início de um processo construtivo em qualquer hierarquia, as fácies Lc apresentam caráter de superfícies delimitantes dos elementos arquitetônicos do sambaqui Jabuticabeira II.

As fácies conchíferas ( $\mathrm{A} \ell, \mathrm{Cb}, \mathrm{CLb}, \mathrm{C} \boldsymbol{\ell}, \mathrm{CA} \boldsymbol{\ell}$ e $\mathrm{Ap}$ ) representariam processos deposicionais também de caráter episódico, cuja função seria o encobrimento das fácies LC (Klökler, 2008). O mesmo padrão construtivo foi observado por Villagrán (2008) e Klökler (2008) para a "terra preta" (fácies LA) que capeia a acumulação, porém, a substituição das conchas por sedimento orgânico nesta fácies pode indicar escassez de produção de moluscos na fonte lagunar, ou afastamento progressivo da fonte de empréstimo, ocasionados pelo processo de assoreamento e restrição dos corpos de água da região. Este 
assoreamento é evidenciado ainda pela própria sucessão de associações de fácies de hierarquia maior identificada, no pacote conchífero, neste trabalho.

A dissemelhança entre as associações de camadas realizadas por Klökler $(2001,2008)$ e Bendazzoli (2007) com relação às do presente estudo resume-se assim aos critérios (menos descritivos e mais interpretativos) de delimitação e à escala ou hierarquia (menor) de associação. Enquanto o enfoque e a escala adotada por aquelas autoras ressalta (e interpreta) a rotina construtiva do sambaqui, o caráter essencialmente descritivo e a escala mais abrangente de associação adotados no presente estudo evidenciam processos outros que não estão tão clara ou diretamente ligados ao processo construtivo do sítio.

Sendo as associações de fácies aqui reconhecidas distintas quanto à granulação e composição, seu significado interpretativo mais evidente é de proveniência do material construtivo. Nesse sentido, chamam a atenção as possibilidades de paralelo entre a sucessão de fácies no sambaqui e a sucessão de fácies no terreno paleolagunar adjacente. Uma interpretação seria a de que a escolha do material construtivo do sambaqui teria sido, em algum grau, controlada pela disponibilidade de matéria prima geológica, principalmente no sistema lagunar. Sob essa perspectiva, a sucessão de associações de fácies no sambaqui relaciona-se ao processo de assoreamento progressivo sofrido, na segunda metade do Holoceno, pelo sistema lagunar adjacente (Giannini, 1993; Giannini et al., 2001; Giannini, 2002; Kneip, 2004, Amaral, 2008). De acordo com este modelo, por volta de 3000 anos AP, idade máxima obtida para o Jabuticabeira II, a proximidade da laguna em relação ao sambaqui favoreceu o empréstimo de lama de fundo lagunar, refletido nas fácies de composição lamosa (Al e CLb) de posição basal na coluna estratigráfica do sítio; em seguida, reflexo do distanciamento progressivo do fundo inframarés lamoso da laguna, teriase o aumento gradual da participação de fácies arenosas, primeiro de modo transicional, com intercalações de fácies com areia ( $\mathrm{CA} \ell$ ) entremeadas às lamosas e, depois, no topo, de modo mais pleno, com associação de fácies sem termos lamosos (Cl) (Figura 31 a Figura 34).

Independente destas variações, o cascalho bioclástico é sempre presente em toda a extensão da coluna estratigráfica do sambaqui, mas apresenta diminuição ascendente na freqüência de conchas inteiras. Considerando que as conchas inteiras são mais abundantes nas fácies de fundo lagunar (inframarés), abaixo do nível médio de ação de ondas e correntes, a diminuição ascendente na concentração de conchas inteiras pode ser relacionada à redução ou afastamento progressivo dos bancos de conchas, ocasionados pela regressão e assoreamento lagunar. Esta tendência de diminuição das conchas inteiras para cima coincide com o observado na própria sucessão paleolagunar, onde as conchas em 
posição de vida são mais comuns na base (Figura 39, Figura 45 e Figura 49), registro de deposição lagunar em fundo inframaré.

A coluna estratigráfica do sambaqui Jabuticabeira II (Figura 32) é finalizada pela fácies LA ("terra preta" ou "capa preta"), resultado de mudança do regime deposicional até então vigente (DeBlasis, 2005; DeBlasis et al., 2007), com diminuição drástica na concentração de conchas (inteiras e fragmentadas) concomitante a aumento de componentes siliciclásticos (Figura 62).

Depósitos correlatos a fácies LA do sambaqui Jabuticabeira II foram estudados com detalhe por Villagrán (2008), em outros lócus onde esta fácies se encontra mais espessa, o que permitiu pormenorizar seus aspectos estratigráficos. Com isto, identificaram-se cinco tipos de arqueofácies (fácies aplicada a materiais de contexto arqueológico, segundo a autora) e quatro subfácies, organizadas macroscopicamente de acordo com a composição (incluindo cor, conteúdo orgânico e mineralogia), textura, geometria externa, estruturas internas e componentes antrópicos.

Características composicionais das arqueofácies descritas na "terra preta" de topo do sítio por Villagrán (2008) coincidem com as reconhecidas nesta Dissertação quanto ao alto conteúdo de ossos de peixe, carvão, cinzas e outros produtos de combustão e ao baixo conteúdo de conchas em comparação com fácies sotopostas. Em contrapartida, a fosfomicrita identificada pela autora na micromassa daqueles lócus não foi encontrada no sedimento escuro das lâminas "funerárias" (Lc) dos lócus 1 e 2 aqui estudado, cuja composição é predominantemente silicosa (Figura 106 e Figura 108a), interpretada como produto de alteração térmica de fitólitos.

Outras características da fácies LA ("terra preta") identificadas por Villagrán (2008) parecem estender-se, em escala estratigráfica reduzida, às lâminas da fácies Lc entremeadas com as fácies conchíferas, aqui estudadas. Assim como a fácies LA descrita também por aquela autora, a fácies Lc apresenta, de acordo com os resultados aqui obtidos, alto conteúdo de materiais oriundos de processamento antrópico, principalmente de combustão, finamente fragmentados, incluindo carvão, ossos de peixe calcinados e escória vítrea, além de fragmentos fosfáticos. Estes fragmentos fosfáticos, os quais se encerram preferencialmente na fácies Lc, possuem origem atrelada ao processamento antrópico (Figura 87a), incluindo prováveis restos de coprólitos, observados na análise micromorfológica (Figura 86). Esta composição tão discrepante é o que diferencia as fácies Lc e LA das fácies conchíferas, aparentemente com menor grau de "beneficiamento" antrópico. 
Embora o método detalhado de associação de fácies não esteja claro no trabalho de Villagrán (2008), pode-se depreender, através da observação das seções por ela apresentadas, que unidades arqueossedimentares convencionais (confinadas estratigraficamente) foram descritas em campo, e que de posse da descrição destas unidades, foi feito o agrupamento cujo resultado são as arqueofácies (não confinadas, isto é, passíveis de recorrência).

Cabe reforçar a filosofia do conceito de fácies como sendo aberto, moldável, adimensional e atemporal. A criação de terminologias ("complexificação" do conceito), que não acrescentam ao conceito de fácies, conflita com a própria filosofia da análise de fácies. Em contrapartida, a terminologia (arqueofácies) pode ser útil na diferenciação de processos deposicionais antrópicos dos processos deposicionais geológicos, na fase interpretativa do trabalho arqueológico, porém esta diferenciação é complexa e ocorre, na maioria dos casos, nas etapas finas de interpretação do processo formativo do sítio, quando de posse da maior quantidade possível de informações descritivas e análises laboratoriais.

Em relação aos sambaquis de menor porte estudados nesta Dissertação (Carniça III e Encantada III), observa-se menor complexidade estratigráfica em comparação ao Jabuticabeira II (item 5.1). Esta menor complexidade reflete-se composicionalmente, principalmente em relação a maior quantidade de bioclastos na fácies "terra preta" (Figura 66 e Figura 67) em comparação às fácies Lc e LA do sítio Jabuticabeira II. Outro fator que denota a diferença composicional entre as "terras pretas" é a assinatura isotópica do ${ }^{15} \mathrm{~N}$ (item 5.8). Para as "terras pretas" do sambaqui Jabuticabeira II, a assinatura encontrada é característica de matéria orgânica de origem animal em estado putrefato, bem diferenciado do ${ }^{15} \mathrm{~N}$ da matéria orgânica paleolagunar (Figura 114). Já a "terra preta" do sambaqui Encantadas III, em contraste, possui assinatura isotópica de $\mathrm{N}$ semelhante a do depósito paleolagunar de seu entorno, típico de plantas marinhas; e a do sambaqui Carniça III apresenta valores semelhantes aos encontrados para os depósitos paleolagunares próximos ao sítio Jabuticabeira II (Figura 114).

O sambaqui Jabuticabeira II, representante dos sambaquis de maior porte da região neste estudo, apresenta notória complexidade estratigráfica em relação aos sambaquis de menor porte (Encantadas III e Carniça II). Esta complexidade reflete-se na composição das fácies "terra preta" cujas características composicionais são muito mais distintas, em comparação com os sedimentos paleolagunares do entorno, no sambaqui Jabuticabeira II (tanto Lc como LA) de que nos sambaquis Encantadas III e Carniça II. 


\subsection{Proveniência dos sedimentos dos sambaquis Jabuticabeira II, Carniça III e Encantada III}

O aprofundamento dos conhecimentos sobre estratigrafia e processos construtivos dos sambaquis do litoral sul de Santa Catarina tem suscitado questionamentos acerca da origem do material orgânico escuro que compõe importantes superfícies delimitantes, bem representadas nas lâminas "funerárias" do sambaqui Jabuticabeira II, e as camadas de "terra preta" encontradas em alguns sambaquis de grande e de pequeno porte.

Giannini et al. (2005), baseados na semelhança textural e composicional, observada em campo, entre estes tipos de sedimentos arqueológicos e os depósitos paleolagunares locais, aventam a possibilidade de fonte nestes depósitos (representados pela sua fácies areno-lamosa: ver item 5.1), e sugerem estudos sistemáticos de análise de fácies e caracterização laboratorial para verificação desta hipótese.

\subsubsection{Origem dos materiais arenosos não orgânicos}

É possível distinguir os sedimentos eólicos das diversas gerações (1, 2 e 3; sensu Giannini, 1993, 2002 e Giannini et al. 2007) dos sedimentos paleolagunares e dos oriundos do sambaqui Jabuticabeira II. Dentre os sedimentos eólicos, os das gerações 1 e 2 possuem maior afinidade com os sedimentos paleolagunares (Figura 54 e Figura 55). Esta diferenciação pode ser reflexo da melhor seleção granulométrica experimentada pelos sedimentos eólicos da geração 3 , formada em parte por retrabalhamento sedimentar das gerações anteriores e de outros tipos de sedimentos preexistentes.

A afinidade entre sedimentos paleolagunares e de sambaqui, quanto aos parâmetros granulométricos, pode ser observada também para o sambaqui Encantada III. Já no sambaqui Carniça III, evidenciaram-se características granulométricas semelhantes não somente com os sedimentos paleolagunasres (cordões litorâneos) de Campos Verdes (Figura 56 e Figura 57), como, principalmente, com dunas eólicas da geração 3 transgressivas sobre a planície de cordões.

Esta semelhança granulométrica entre sedimentos arqueológicos e naturais da região de Campos Verdes já fora notada por Tanaka (2007, 2009), que encontrou grande homogeneidade textural entre a fácies arenosa do sambaqui Carniça III e sedimentos de cordões litorâneos e dunas eólicas.

Em uma visão mais abrangente, as análises de granulometria da fração areia e mineralogia de pesados, voltadas a estudo de proveniência dos materiais constitutivos dos sambaquis, evidenciam que os resultados são controlados principalmente por variáveis geográficas. Assim, tanto os parâmetros granulométricos quanto os índices de estabilidade 
química de minerais pesados são semelhantes para fácies (ou grupos de fácies) da mesma localidade (Figuras 53 a 55).

\subsubsection{Origem da matéria orgânica}

Embora os teores de matéria orgânica (MO) em sedimentos geogênicos e antropogênicos sejam semelhantes entre si na região de Jabuticabeira, o estudo isotópico de $\mathrm{C}$, aliado a medidas da razão $\mathrm{C} / \mathrm{N}$, indica origens distintas. O tipo de $\mathrm{MO}$ encontrado em depósitos geogênicos de Jabuticabeira, hoje situados em brejo e pântano de intermarés superior e correlatos a antigo sistema lagunar (testemunho RIA, do Vale do Riachinho, em Amaral, 2008; p. 133-134) refere-se à acumulação de $\mathrm{MO}$ de origem vegetal com características C3, enquanto, a MO antropogênica (fácies Lc e LA) possui características desde marinha até C3 (Figura 113).

O carbono analisado nas fácies Lc e LA do sambaqui Jabuticabeira II consiste predominantemente de carvões, tecidos vegetais e, subordinadamente, matéria orgânica coloidal, conforme observações micromorfológicas. A grande variação dos valores de $\delta^{13} \mathrm{C} e$ $\mathrm{C} / \mathrm{N}$ na $\mathrm{MO}$ antropogênica do sambaqui Jabuticabeira II reflete sua característica complexa de mistura e retrabalhamento de materiais, diferente dos sambaquis Encantada III e Carniça III, cujas MO possuem origens muito semelhante às dos depósitos geogênicos adjacentes (Figura 113 e Figura 120b).

A origem da MO antropogênica do Jabuticabeira II pode ser melhor compreendida ao observar-se a característica isotópica do nitrogênio, cujos resultados apontam para fonte animal (ver item 5.8) preferencialmente à vegetal.

Os fragmentos de carvão e tecidos vegetais comumente encontrados nas fácies Lc e LA do Jabuticabeira II, provavelmente as únicas fontes de MO vegetal destas fácies, devem influenciar o sinal isotópico do carbono, dada alguma semelhança doð ${ }^{13} \mathrm{C}$ obtido para estas fácies com a assinatura isotópica obtidas por Amaral (2008) nos depósitos paleolagunares do vale do rio Riachinho, distante 6,5 km do sambaqui Jabuticabeira II. A semelhança deve-se à distribuição entre $\mathrm{MO}$ de origem marinha e vegetação $\mathrm{C}$, com algumas amostras apontando mistura entre estes dois campos, tanto neste trabalho (Figura 120b) quanto no de Amaral (2008) (Figura 120a).

A semelhança do sinal isotópico do ${ }^{13} \mathrm{C}$ obtido neste trabalho com o de Amaral (2008), somado à característica de origem animal do sinal isotópico do ${ }^{15} \mathrm{~N}$ obtido para o sambaqui Jabuticabeira II, constitui evidência de mistura entre MO animal e vegetal paleolagunar como proveniência do material constituinte das fácies Lc e LA deste sambaqui. 
a)

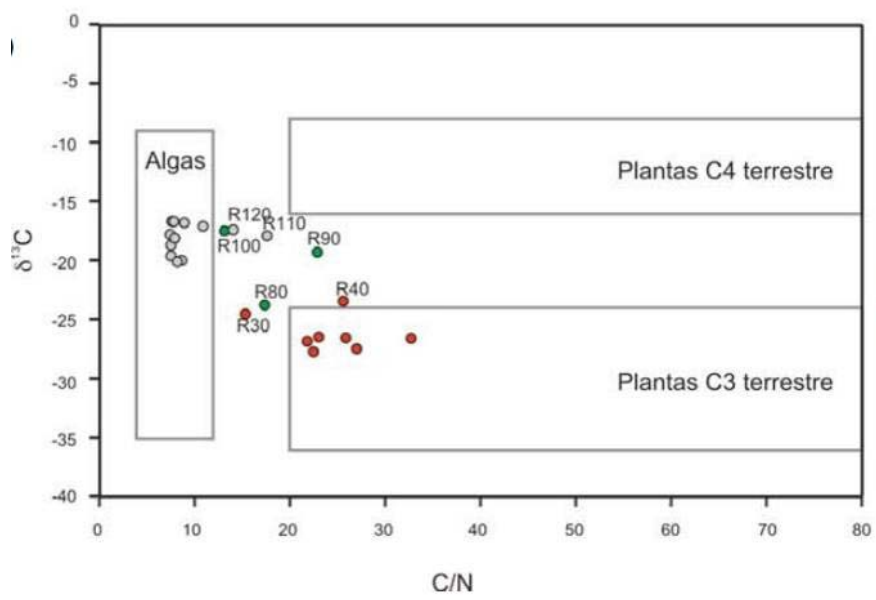

b)

\section{Corg/Ntotal}

5678991011121314151617181920212223242526272829303132333435

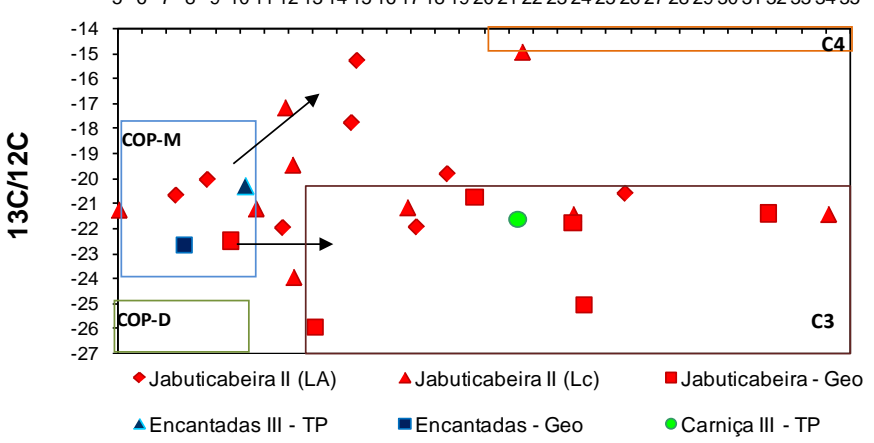

Figura 120 - Comparação entre dois diagramas de origem de $\mathrm{MO}\left(\delta^{13} \mathrm{C} x\right.$ $\mathrm{C} / \mathrm{N})$. Em a, origem da $\mathrm{MO}$ do vale do rio Riachinho, testemunho RIA, de Amaral (2008) e em b, origem da MO das amostras deste estudo. Notar semelhança na distribuição dos valores entre os dois gráficos, incluindo as misturas entre marinhas (Algas e COP-M) e plantas C3. Em a, os pontos vazados correspondem à base do testemunho, os em verde à zona intermediária, e os em vermelho ao topo. 


\subsubsection{Origem dos fosfatos}

O caráter microlaminado e esferulítico dos fragmentos fosfáticos não ósseos é apontada na literatura como típico de dejetos fecais (Courty et al, 1989; Shahack-Gross \& Finkelstein, 2008), inclusive humanos (Paul Goldberg, comunicação pessoal). Outra evidência nesta direção são os valores elevados de $\delta^{15} \mathrm{~N}(>9 \%)$ obtidos na matéria orgânica dos sedimentos pretos dos sambaquis, uma assinatura isotópica de material protéico putrefato. A carne humana e de peixe, bem como os dejetos de animais carnívoros e onívoros, podem produzir assinaturas isotópicas do nitrogênio semelhantes. Adicionadas as evidências micromorfológicas, segundo as quais os fragmentos fosfáticos representam a fossilização de material protéico (fosfoproteínas, ricas em $\mathrm{N}$ ), pode-se inferir que pelo menos parte da composição das lâminas "funerárias" e da "terra preta" do Jabuticabeira II teriam este tipo de origem.

Para verificar a relação entre fragmentos fosfáticos e nitrogênio, optou-se pelo diagrama de dispersão associado ao nível de significância(do teste t de student) das correlações lineares entre estas duas variáveis (Figura 121). Pelo diagrama, pode-se observar correlação positiva entre elas, para a fácies Lc (lâminas "funerárias"), o que reforça a relação, descrita no parágrafo anterior, entre $\mathrm{N}$ e fosfoproteínas de origem animal.

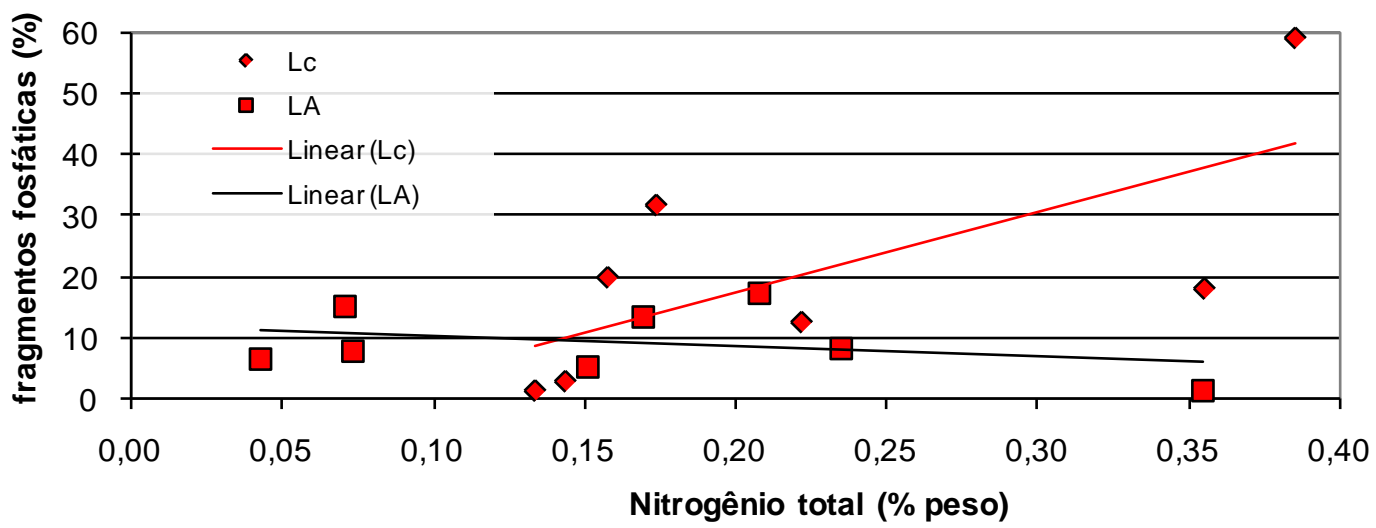

Figura 121 - Diagrama de dispersão entre concentração de fragmentos fosfáticos e \% peso de $\mathrm{N}$ total, separados por fácies Lc ("funerárias") e LA ("terra preta") do sambaqui Jabuticabeira II. Fragmentos no eixo das ordenadas referem-se ao grupo "crostas fosfáticas", obtido por estimativa da fração grossa sob lupa, conforme item 5.5. Para a reta de regressão preta (LA), $\alpha<0,3$; para a reta vermelha (Lc), $\alpha<0,05$.

A textura botrioidal presente em grande parte dos fragmentos fosfáticos é atribuída à precipitação na presença de microorganismos (Gilinskaya et al., 2007). Estudos morfológicos sob microscópio eletrônico de varredura (MEV) efetuados em fragmentos de sedimento in 
natura e fragmentos fosfáticos retirados das lâminas "funerárias" e da camada de "terra preta" do sambaqui Jabuticabeira II (Figura 91 a Figura 96) permitiram detectar texturas semelhantes às encontradas por Gilinskaya et al. (2007) em fosfatos precipitados sob a influência de microorganismos. As características micromorfológicas (e nanomorfológicas) constituem mais um indício de origem por degradação de material protéico para os fragmentos fosfáticos presentes nos sedimentos escuros (fácies Lc e LA) do sambaqui Jabuticabeira II. Estes fragmentos fosfáticos, cuja origem imediata seria o transporte até o sambaqui pelo homem, teriam sido formados, em depósitos preexistentes, por processos microbiológicos, de acordo com as evidências apontadas; a origem dos fragmentos de fosfato é portanto distinta das concreções fosfáticas encontradas na interface do "pacote conchífero" com a "terra preta", estas formadas por cimentação autígena a partir de lixiviação química in situ (Mazini \& Giannini, 2007, Nardini et al., 2008).

A micromassa dos mesmos sedimentos escuros das fácies Lc e LA apresenta ao microscópio de luz polarizada, cor marrom escuro a pardo amarelado e comportamento óptico predominantemente isótropo, com porções anisótropas compostas, grande parte, por calcimicrita. Esta calcimicrita é associada por à presença de $\mathrm{CaO}$ substituído por $\mathrm{CaCO}_{3}$, cuja origem primária, conforme aceito por diversos autores (Courty, 1983; Schiegl et al., 1996, Gebhardt \& Langohr, 1999; Goldberg \& Arpin, 1999; Berna et al., 2007), é a decarbonatação da vevelita $\left(\mathrm{Ca}\left[\mathrm{C}_{2} \mathrm{O}_{4}\right] \cdot \mathrm{H}_{2} \mathrm{O}\right)$,

Estudando depósito correlato a LA em outro lócus do mesmo sambaqui, Villagrán (2008) interpretou micromorfologicamente a micromassa isótropa encontrada como fosfomicrita, produto da precipitação de fosfato dos ossos abundantemente presentes na "terra preta" do Jabuticabeira II.

O mapeamento elementar da micromassa de algumas lâminas "funerárias" ao sistema MEV-EDS permitiu observar, porém, a existência de composição predominantemente silicosa e não fosfática (Figura 105 a Figura 109). Fonte provável desta sílica seriam fitólitos que compõem a estrutura celular de tecidos vegetais (Pearsall \& Piperno, 1993), e que ocorrem abundantemente nas fácies Lc e LA, inclusive associados à escória vítrea (Figura 77, Figura 97, Figura 98, e Figura 108a).

A diferença na composição da micromassa estudada por Villagrán (2008) e a aqui investigada pode dever-se a uma questão de posição estratigráfica. A camada de "terra preta" estudada por aquela autora, por capear o sítio, está sujeita a processos intempéricos intensos de remobilização do fósforo dos ossos e sua conseqüente repreciptação como fosfomicrita. Já nas lâminas "funerárias" (fácies Lc), a micromassa de composição ora silicosa ora calcimicrítica encontra-se em ambiente geoquímico tamponado pelo carbonato 
de cálcio das conchas (fácies conchíferas). sempre presentes em abundância acima e abaixo da fácies. Com este tamponamento, as soluções percolantes inicialmente ácidas são gradualmente neutralizadas, perdendo o efeito de lixiviação tanto do fósforo quanto do próprio cálcio.

A situação geoquímica "protegida" da fácies Lc, a ausência de evidências de pedogênese, bem como a hipótese tafonômica de soterramento rápido (aceita a concepção de ritmo construtivo de Bendazzoli, 2007 e Klökler, 2008) permitem sugerir que a composição e organização dos componentes das lâminas "funerárias" encontram-se em bom estado de preservação.

\subsubsection{Origem e transporte dos materiais constituintes das fácies orgânicas do Jabuticabeira II}

A composição e organização dos componentes da fácies Lc são sugestivas de origem terciária (sensu Schiffer, 1983, 1987 apud Villagrán, 2008): restos de peixe, fogueiras (carvão, escória vítrea, fitólitos e tecidos vegetais e micromassa calcimicrítica) e excrementos (fragmentos e incrustações fosfáticas com texturas botrioidal, esferulítica e microlaminada) teriam sido acumulados por um período num depósito secundário e depois transportados para o sambaqui. Mesmo tipo de interpretação já fora adotada por Villagrán (2008) para a camada de "terra preta" de topo, indício de que o método construtivo do sambaqui Jabuticabeira II permaneceu inalterado, não obstante a mudança de composição e de contexto estratigráfico na passagem da camada conchífera para a camada de "terra preta".

A análise dos fosfatos nas fácies Lc e LA permitiram deduzir que os revestimentos fosfáticos com evidências de transporte são, pelo menos em grande parte, fósseis (prováveis coprólitos) transportados de seu local de deposição original para o sambaqui. Já a fosfomicrita que incide na micromassa parece se restringir à "terra preta" que capeia os sítios estudados, sendo originária de processos diagenéticos cujo desenvolvimento culmina na formação de concreções fosfáticas, observadas comumente na interface entre a "terra preta" e o "pacote conchífero" do sambaqui.

Com exceção da areia terrígena, os demais componentes das fácies Lc e LA são oriundos de processamento antrópico (doméstico?). A ausência de estruturas (em campo) e microestruturas características de deposição geogênica preservadas, bem como as assinaturas isotópicas de mistura de materiais de origem animal e vegetal, grande parte termicamente alterado, inviabiliza a hipótese dos depósitos geogênicos remanejados integralmente pelo homem. 
A observação micromorfológica (item 5.6) das terras pretas nos sambaquis estudados indica que grande parte dos componentes do arcabouço está fora de seu contexto original e apresenta feições de transporte. As evidências incluem fragmentos fosfáticos não ósseos microlaminados ou esferulíticos revestidos pela micromassa, nódulos anórticos, fragmentos de valvas de moluscos e carvão revestidos por fosfato e/ou micromassa e fragmentos de ossos com evidências de alteração térmica coexistindo (misturados) com ossos aparentemente sem alteração. Uma vez que o arcabouço, composto grande parte por fragmentos antropogênicos, foi transportado até o sambaqui, de onde ele veio? E, admitida a hipótese de depósito antrópico (secundário) como fonte imediata, levantada por Villagrán (2008) e Klökler (2008), onde se encontram os vestígios deste suposto depósito secundário?

Fragmentos de produtos de combustão, ossos e bioclastos (Figura 66) foram encontrados nos sedimentos paleolagunares adjacentes ao sambaqui Jabuticabeira II, bem como estilhas e microfragmentos de ossos queimados puderam ser observados, em seu contexto micromorfológico, nestes mesmos depósitos. A presença destes componentes parece constituir vestígio do suposto depósito secundário, e, portanto, indício de que este depósito estaria situado na paleolaguna vizinha ao sítio. Maior quantidade de amostras e análises mais numerosas e abrangentes dos depósitos paleolagunares necessitam, porém, ser obtidos, para melhor avaliar esta hipótese.

A exemplo do sambaqui Jabuticabeira II, as "terras pretas" e fácies arenosas dos sambaquis de menor porte aqui investigados (Encantadas III e Carniça III) possuem componentes característicos de beneficiamento antrópico, tais como produtos de combustão, revestimentos fosfáticos alóctones e fragmentos de ossos (Figura 66 e Figura 67). No entanto, a assinatura isotópica do carbono e nitrogênio destes sambaquis menores indica pouca diferenciação com respeito aos depósitos paleolagunares adjacentes, o que reforça a idéia de que eles representem padrão de construção diferenciado em relação aos sambaquis monumentais tão expressivos nesta região. 


\section{CONCLUSÕES FINAIS}

A análise dos resultados obtidos para este estudo permitiu, em atendimento aos objetivos traçados, chegar às seguintes conclusões finais:

A estratigrafia do sambaqui Jabuticabeira II é composta por intercalação de camadas predominantemente conchíferas, ricas em sedimentos terrígenos, e lâminas escuras, com abundância de produtos de combustão e sepultamentos (fácies Lc), capeada por camada espessa, terrosa, com grande conteúdo em ossos de peixe, artefatos líticos e sepultamentos (fácies LA).

A estratigrafia dos sambaquis Carniça III e Encantada III remete a empilhamento simples, composto por núcleo de sedimento arenoso terrígeno (fácies arenosa) e capeamento de sedimento escuro, orgânico, contendo produtos de combustão, ossos de peixe e conchas (fácies "terra preta").

As fácies identificadas na camada comchífera do sambaqui Jabuticabeira II encontram-se organizadas da base para o topo, em três associações: cascalholamosa, areno-lamosa e cascalho-arenosa.

As fácies Lc (lâminas "funerárias"), bem como a fácies LA ("terra preta") que capeia o sambaqui Jabuticabeira II, constituem superfícies delimitantes de elementos arquitetônicos de diversas hierarquias.

A sucessão de fácies descritivas do sambaqui Jabuticabeira II, interpretada em termos de proveniência dos materiais construtivos, pode ser considerada registro do processo de progressiva restrição e assoreamento do sistema lagunar. Isto permite avaliar este sambaqui como testemunho dos processos geológicos locais.

As análises dos sedimentos arenosos não orgânicos permite concluir que o controle granulométrico e mineralógico tem caráter geográfico, com grande afinidade dos sambaquis Jabuticabeira II e Encantada III com o sistema lagunar e do sambaqui Carniça III com os cordões litorâneos e paleodunas eólicas de Campos Verdes. A afinidade entre sedimentos de sambaquis e de sistemas deposicionais vizinhos é tanto maior quanto mais próximos do sítio tenham estado estes sistemas. 
As "terras pretas" dos sambaquis Encantadas III e Carniça III guardam mais semelhança isotópica e composicional com os sedimentos paleolagunares adjacentes que as do sambaqui Jabuticabeira II.

As análises efetuadas nas lâminas "funerárias" e na camada de "terra preta" do sambaqui Jabuticabeira II remetem a expressivo processamento antrópico, sendo refutada a hipótese de que se trate de depósitos geogênicos remanejados integralmente pelo homem.

$>$ Os sedimentos processados antropicamente podem ser interpretados como produtos de acumulação de refugos do cotidiano do homem do sambaqui. Indícios da proveniência exata do local de acumulação destes refugos não se encontraram nos pontos amostrados, porém vestígios antrópicos (estilhas e ossos queimados) foram registrados nos sedimentos paleolagunares do entorno do sambaqui Jabuticabeira II. 


\section{REFERÊNCIAS BIBLIOGRÁFICAS}

Albert, R. M., Lavi, O., Estroff, L., Weiner, S., Tsatskin, A., Ronen, A., Lev-Yadun, S., 1999. Mode of Occupation of Tabun Cave, Mt Carmel, Israel During the Mousterian Period: A Study of the Sediments and Phytoliths. Journal of Archaeological Science, 26, 1249-1260.

Allen, J. R. L., 1983. Studies in fluviatile sedimentation: bars, bar complexes and sandstones sheets (low-sinuosity braided streams) in the Brownstones (L. Denonian), Welsh Borders. Sedimentary Geology, 33, 237-293.

Amaral, P. G. C., 2008. Evolução da sedimentação lagunar Holocênica na região de Jaguaruna, estado de Santa Catarina: uma abordagem sedimentológicamicropaleontológica integrada. Tese (Doutorado). Instituto de Geociências, Universidade de São Paulo, São Paulo. 165p.

Anderton, R. 1985. Clastic facies models and facies analysis. In: Brenchley, P.J., Williams, B.P.J. (Ed), Sedimentology: Recent developments and applied aspects. Am. Ass. of Petroleum Geologists, 348 p.

Angulo R. J., Giannini P. C. F., Suguio, K., Pessenda, L. C. R., 1999. Relative sea-level changes in the last 5500 years in southern Brazil Laguna-Imbituba region, Santa Catarina State/based on vermetid ${ }^{14} \mathrm{C}$ ages. Marine Geology, 159, 323-339.

Angulo R. J., Lessa, G. C., Souza, M. C., 2006. A critical review of mid to late Holocene sealevel fluctuations on the eastern Brazilian coastline. Quaternary Science Reviews, 25, 486-506.

Barbosa, P. N., 2007. A Coisa Ficou Preta: estudo do processo de formação da "terra preta" do sítio arqueológico Jabuticabeira II. Tese (Doutorado). Museu de Arqueologia e Etnologia, Universidade de São Paulo, São Paulo.

Bendazzoli, C., 2007. O processo de formação dos sambaquis: Uma leitura estratigráfica do sítio Jabuticabeira II, SC. Dissertação (Mestrado), Museu de Arqueologia e Etnologia, Universidade de São Paulo, São Paulo. 185 p.

Berna, F., Behar, A., Shahack-Gross, R., Berg, J., Boaretto, E., Gilboa, A., Sharon, I., Shalev, S., Shilstein, S., Yahalom-Mack, N., Zorn, J.R., Weiner, S., 2007. Sediments exposed to high temperatures: reconstructing pyrotechnological processes in Late Bronze and Iron Age Strata at Tel Dor (Israel). Journal of Archaeological Science, 34, 358-373. 
Bogaard, A., Heaton, T.H.E., Poulton, P., Merbach, I., 2007. The impact of manuring on nitrogen isotope ratios in cereals: archaeological implications for reconstruction of diet and crop management practices. Journal of Archaeological Science, 34, 335-343.

Brewer, R., 1976. Fabric and mineral analysis of soils, second ed. John Wiley \& Sons, Inc., Nova lorque. $482 \mathrm{p}$.

Bullock, P., Fedoroff, N., Jongerius, A., Stoops, G., Tursina, T., Babel, U., 1985. Handbook for soil thin section description. Waine Research Publications, Wolverhampton, Reino Unido. 152 p.

Carozzi, A. V., 1993. Sedimentary petrography. PTR Prentice-Hall, Inc. Nova Jersey. 263 p.

Commisso, R. G., Nelson, D. E., 2006. Modern plant $\delta^{15} \mathrm{~N}$ values reflect ancient human activity. Journal of Archaeological Science, 33, 1167-1176.

Courty, M. A., 1983. Interpretation des aires de combustion par la micromorphologie. Bulletin de la Société Prehistorique Française, 80, 169-171.

Courty, M. A., 2001. Microfacies analysis assisting archaeological stratigraphy. In: Goldberg, P., Holliday, V.T., Ferring, C. R. (Eds.), Earth sciences and archaeology. Kuwer Academic I Plenum Publishers, Nova Iorque. 513 p.

Costa, R. Z. A., 2005. Uma contribuição ao estudo da técnica construtiva das alvenarias de pedra entaipada com argamassa de areia e cal. Dissertação (Mestrado) concluída em, não publicada, Instituto de Pesquisas Tecnológicas do Estado de São Paulo, São Paulo. 154 p.

Courty, M. A., Fédoroff, N., 1985. Micromorphology of recent and buried soils in a semiarid region of northwestern India. Geoderma, 35, 287-332.

Creemings, D.L., 2003. Micromorphology of Cotinga Mound, West Virginia. Geoarchaeology, 20, 581-597.

DeBlasis, P., 2005. Os sambaquis vistos através de um sambaqui. Tese (Livre-docência), Museu de Arqueologia e Etnologia. Universidade de São Paulo, São Paulo.

DeBlasis, P., Fish, S. K., Gaspar, M. D., Fish, P, R., 1998. Some references for the discussion of complexity among the sambaqui moundbuilders from the southern shores of Brazil. Revista de Arqueologia Americana, 15, 75-105.

DeBlasis, P., Kneip, A., Scheel-Ybert, R., Giannini, P. C. F., Gaspar, M. D., 2007. Sambaquis e paisagem: dinâmica natural e arqueologia regional no litoral do Sul do Brasil. Arqueología Suramericana, 3, 29-61. 
Ferreira Junior, P. D. e Castro, P. T. A., 2001. Associação vertical de fácies e elementos arquitecturais: concepções concorrentes e complementares na caracterização de ambientes aluviais. e-Terra Revista Electrónica de Ciências da Terra. GEOTIC Sociedade Geológica de Portugal. 1, 1-35.

Fisher, W. L., McGowen, J. H., 1967. Depositional systems in the Wilcox Group of Texas and their relationship to occurrence of oil and gas. Gulf Coast Assoc. Geol. Socs. Trans., 17, 105-125.

Fogg, G. E., Rolston, D. E., Decker, D. L., Louie, D. T., Grismer, M. E., 2005. Spatial variation in nitrogen isotope values beneath nitrate contamination sources. Ground Water, 36, 418-426.

Folk, R. L., 1959. Practical petrographic classification of limestones. American Association of Petroleum Geologists Bulletin, 43, 1-38.

Galehouse, J. S., 1971. Point counting. In: Carver, R. (Ed). Procedures in sedimentary petrology. Wiley-Interscience. 385-407.

Gasche, H., Tunca, O., 1983. Guide to archaeostratigraphic classification and terminology: definitions and principles. Journal of Field Archaeology, 10, 325-335.

Gaspar, M. D., 2002. Padrão de Assentamento e Formação de Sambquis: arqueologia e preservação em Santa Catarina. Revista de Arqueologia do IPHAN, 1, 57-62.

Gebhardt, A., Langohr, R., 1999. Micromorphological study of construction materials and living floors in the medieval motte of Werken (West Flanders, Belgium). Geoarchaeology, $14,595-620$.

Gesicki, A.L.D., 2007. Evolução diagenética das formações Pirambóia e Botucatu (sistema aqüífero Guarani) no Estado de São Paulo. Tese de Doutoramento, Instituto de Geociências, Universidade de São Paulo, São Paulo.

Giannini, P. C. F., 1993. Sistemas Deposicionais no Quaternário Costeiro entre Jaguaruna e Imbituba (SC), Tese (Doutorado), Instituto de Geociências, Universidade de São Paulo, São Paulo. 
Giannini, P. C. F., 2002. Complexo lagunar centro-sul catarinense. In: Schobbenhaus, C.; Campos, D. A.; Queiroz, E. T.; Winge, M.; Berbert-Born, M. (eds). Sítios Geológicos e Paleontológicos do Brasil. Brasília, DNPM, SIGEP - Comissão Brasileira de Sítios Geológicos e Paleontológicos, p. 213-222. Edição eletrônica em www.unb.br/ig/sigep

Giannini, P. C. F., 2006. Petrografia sedimentar. Prática 2. Rochas sedimentres. Guia ilustrado de descrição. Instituto de Geociências, Universidade de São Paulo. 16 p.

Giannini, P. C. F., 2007. Sistemas deposicionais eólicos no quaternário costeiro do Brasil. Tese (Livre-docência), Instituto de Geociências. Universidade de São Paulo, São Paulo.

Giannini, P. C. F., Santos, E. R., 1994. Padrões de varição espacial e temporal na morfologia de dunas de orla costeira no Centro-sul catarinense. Boletim Paranaense de Geociências, Curitiba, PR, 42, 73-96.

Giannini, P. C. F.; Suguio, K. 1994. Diferenciação entre gerações de depósitos eólicos quaternários na costa centro-sul de Santa Catarina. In: Congresso Brasileiro de Geologia, Balneário Camboriú. Resumos Expandidos. Balneário Camboriú: SBG, 1994. p. $402-403$.

Giannini, P. C. F., Nascimento Junior, D. R. do, 2006. Momento 4.1.xls. Programa de computador. Laboratório de Petrografia Sedimentar. Instituto de Geociências, Universidade de São Paulo, São Paulo.

Giannini, P. C. F., Sawakuchi, A. O., Martinho, C. T., 2001. A estratigrafia de sequências na evolução das dunas costeiras de Santa Catarina, Sul do Brasil. Congresso do Quaternário dos Países de Língua Ibérica, 1, Lisboa. Actas.... Sociedade Geol. de Portugal, Grupo de Trabalho Português para o Estudo do Quaternário e Assoc. Espagn. para Estudio Del Quaternário, p. 117-120.

Giannini, P. C. F., Angulo, R. J, Souza, M. C., Kogut, J. S., Delai, M. S., 2004. A erosão na costa leste da llha do Mel, baía de Paranaguá, estado do Paraná: Modelo baseado na distribuição espacial de formas deposicionais e propriedades sedimentológicas. Revista Brasileira de Geociências, 34, 231-242.

Giannini, P. C. F., DeBlasis, P., Sawakuchi, A.O., Amaral, P.G.C., 2005. Processos e materiais geológicos e a construção de sambaquis no litoral sul de Santa Catarina. $X$ Congresso da Associação Brasileira de Estudos do Quaternário (Abequa). Resumo expandido, 11, Guarapari. CD-ROM. 
Giannini, P. C. F.; Sawakuchi, A. O.; Martinho, C. T.; Tatumi, S. H. 2007. Eolian depositional episodes controlled by Late Quaternary relative sea level changes on the ImbitubaLaguna coast (southern Brazil). Marine Geology, Amsterdam, v. 237, p. 143-168,.

Giannini, P. C. F.; DeBlasis, P.; Angulo, R. J.; Menezes, P. M. L.; Fornari, M.; Nascimento, D. R., Jr.; Sawakuchi, A. O.; Villagrán, X. S.; Amaral, P. G. C.; Pessenda, L. C. R. inédito The shell midden Encantada III and the Holocene sedimentary evolution of the Garopaba do Sul backbarrier (Jaguaruna, Santa Catarina State, Southern Brasil). Em preparo.

Gilinskaya, L. G., Zanin, Y. N., Rudina, N. A., 2007. Bacterial genesis of calcium phosphates in human organism and nature. Lithology and Mineral Resources, 42, 56-67.

Goldberg, P., 1992. Micromorphology, soils and archaeological sites. In: Holliday, V.T. (Ed.), Soils in archaeology, landscape evolution and human occupation. Smithsonian Institution Press, Washington DC. 272 p.

Goldberg, P., Arpin, T. L., 1999. Micromorphological analysis of sediments from Meadowcroft Rockshelter, Pennsylvania: Implications for radiocarbon dating. Journal of Field Archaeology, 26, 325-342.

Harris, E.C., 1979. Principles of archaeological stratigraphy. $1^{\text {st }}$ edition. Academic Press, London. $152 \mathrm{p}$.

Harris, E.C., 1989. Principles of archaeological stratigraphy. $2^{\text {nd }}$ edition. Academic Press, London. $170 \mathrm{p}$.

Holland, S., 2008. UGA stratigraphy lab. http://www.uga.edu/strata/sequence/parasequences.html. Acessado em 06.06.2008.

Holliday V. T., Gartner, W. G., 2007. Methods of soil P analysis in archaeology. Journal of Archaeological Science, 34, 301-333.

Hubert, J. F., 1962. A zircon-turmaline-rutile maturity índex and the dependence of the composition of heavy mineral assemblages with the Gross composition and texture of sandstones. Journal of Sedimentary Petrology, 32, 440-450.

Hubert, J. F., 1971. Analysis of heavy mineral assemblages. In: Carver, R. (Ed). Procedures in sedimentary petrology. Wiley-Interscience. 453-477.

Huckleberry, G., Stein, J. K., Goldberg, P., 2003. Determining the provenience of Kennewick Man skeletal remains through sedimentological analyses. Journal of Archaeological Science, 30, 651-665. 
Hurt, W.R., 1974. The interrelationship between the natural environment and four Sambaquis, coast of Santa Catarina, Brasil. Occasional Pappers and Monographs 1, Indiana University Museum, Bloomington, 1, 1-23.

Kahn, J. S., 1956. The analysis and distribution of the properties of packing in sand size sediments. 1. On the measurement of packing in sandstones. Journal of Geology, 56, 385-395.

Kendall, C., 1998. Tracing nitrogen sources and cycling in catchments. In: Kendall, C. and McDonnell, J. J. (Eds). Isotope Tracers in Catchment Hydrology. Elsevier Science B.V., Amsterdam. 519-576.

Klökler, D. M., 2001. Construindo ou Deixando um Sambaqui: Análise de Sedimentos de um Sambaqui do Litoral Meridional Brasileiro Processos Formativos. Região de Laguna-SC. Dissertação (Mestrado), Museu de Arqueologia e Etnologia, Universidade de São Paulo, São Paulo.

Klökler, D. M., 2008. Food for Body and Soul: Mortuary Ritual in Shell Mounds (Laguna, Brazil). Tese (Doutorado), University of Arizona, Arizona, Estados Unidos da América. $369 \mathrm{p}$.

Kneip, A., 2004. O povo da lagoa: o uso do SIG para modelamento e simulação na área arqueológica do Camacho. Tese (Doutorado), Museu de Arqueologia e Etnologia, Universidade de São Paulo, São Paulo. 171 p.

Lamb, A. L., Wilson, G. P., Leng, J. M., 2006. A review of coastal palaeoclimate and relative sea-level reconstructions using $\delta^{13} \mathrm{C}$ and $\mathrm{C} / \mathrm{N}$ ratios in organic material. Earth Science Reviews, 75, 29-57.

Macphail, R. I., Courty, M. A., Gebhardt, A., 1990. Soil micromorphological evidence of early agriculture in north-west Europe. World Archaeology, 22, 53-69.

Mallol, C., 2006. What's in a beach? Soil micromorphology of sediments from the Lower Paleolithic site of 'Ubeidiya, Israel. Journal of Human Evolution, 51, 185-206.

Martin, L,. Suguio, K., Flexor J.-M., 1988. Hauts niveaux marins pleistocenes du litoral brésilien, Palaeogeography, Palaeoclimatology, Palaeoecology, 68, 231-239.

Martinho, C. T., 2004. Morfodinâmica e Sedimentologia de Campos de Dunas Transgressivos da Região de Jaguaruna-Imbituba. Dissertação (Mestrado). Instituto de Geociências, Universidade de São Paulo, São Paulo.

May, K. L., Miller, A. T., Peters, L. L., 2002. Proceedings of the ocean drilling program. Southeast Pacific Paleoceanographic Transects. Inicial Reports, 202, 33p. 
Mazini, E. B.; Giannini, P. C. F., 2007. Terra preta e concreções carbonáticas em sambaquis da costa catarinense: um modelo de evolução diagenética. Simpósio Internacional de Iniciação Científica da USP, 2007, São Carlos. SIICUSP.

McCormac, F. G.; Hogg, A. G., Blackwell, P. G.; Buck, C. E.; Higham, T. F. G.; Reimer, P. J., 2004. SHCAL04 Southern Hemisphere Calibration, 0-11.0 cal kyr BP. Radiocarbon, v. 46, n. 3, p. 1087-1092.

Meyers, P. A., 1997. Organic geochemical proxies of paleoceanographic, paleolimnologic and paleoclimatic processes. Organic Geochemistry, 27, 213-250.

Miall, E.D., 1985. Architectural-element analysis: A new method of facies analysis applied to fluvial deposits. Earth Sciences Reviews, 22, 261-308.

Miall, E.D., 1996. The Geology of Fluvial Deposits: Sedimentary facies, Basin Analysis, and Petroleum Geology. $1^{\text {st }}$ ed. Springer, Berlin. 582 p.

Milner, H. B., 1962. Sedimentary petrography. Methods in sedimentary petrography, volume $1,4^{\text {th }}$ edition. George Allen \& Unwin Itd.

Nardini, E. M.; Giannini, P. C. F., Menezes, P. M. L. 2008. Concreções Fosfáticas e Carbonáticas em Sambaquis de Laguna e Jaguaruna, SC: um Modelo de Evolução Diagenética. Simpósio Internacional de Iniciação Científica da USP, 2008, São Paulo. $16^{\circ}$ SIICUSP.

Pearsall, D.M., Piperno, D.R., 1993. Current Research in Phytolith Analysis: Applications in Archaeology and Paleoecology. In: Pearsall, D.M., Piperno, D.R. (Eds.), MASCA Research Papers in Science and Archaeology, v. 10. MASCA: The University Museum of Archaeology and Anthropology, University of Pennsylvania. $212 \mathrm{p}$.

Pettijohn, F. J., 1975. Sedimentary rocks. $3^{\text {rd }}$ edition. Harper \& Row, Publishers. Nova Iorque. $628 \mathrm{p}$.

Retallack, G.J., 2001. Soils of the past. An introduction to paleopedology, second ed. Blackwell Science, United Kingdom. 404 p.

Rossetti, D. F., Paz, J. e Góes, A. M. 2004. Facies analysis of the Codó Formation (Late Aptian) in the Grajaú Area, Southern São Luís-Grajaú Basin. Anais da Academia Brasileira de Ciências. 76, p. 791-806.

Sawakuchi, A. O., 2003. Sistemas deposicionais eólicos Quaternários na costa centro-sul catarinense: Relações com o nível do mar. Dissertação (Mestrado). Instituto de Geociências, Universidade de São Paulo, São Paulo. 
Sawakuchi, A. O.; Giannini, P. C. F.; Martinho, C. T. 2003. Episódios de deposição eólica quaternária no litoral centro-sul de Santa Catarina: correlação com variações do nível do mar baseada em idades TL e LOE. In: IX Congresso da Associação Brasileira de Estudos do Quaternário, 2003, Recife-PE. Anais.

Scheel-Ybert, R., 2001. Man and vegetation in southeastern Brazil during the late Holocene. Journal of Archaeological Science, 28, 471-480.

Schiegl, S., Goldberg, P., Bar-Yosef, O., Weiner, S., 1996. Ash deposits in Hayonim and Kebara caves, Israel: Macroscopic, microscopic and mineralogical observations, and their archaeological implications. Journal of Archaeological Science, 23, 763-781.

Schiffer, M. B., 1976. Behavioral Science. Academic Press, Nova Iorque, 222.

Shahack-Gross, R., Finkelstein, I. 2008. Subsistence practices in an arid environment: a geoarchaeological investigation in an Iron Age site, the Negev Highlands, Israel. Journal of Archaeological Science, 35, 965-982.

Shahack-Gross, R., Ayalon, A., Goldberg, P., Goren, Y., Ofek, B., Rabinovich, R., Hovers, E., 2008. Formation processes of cemented features in karstic cave sites revealed using stable oxygen and carbon isotopic analyses: A case study at Middle Paleolithic Amud cave, Israel. Geoarchaeology, 23, 43-62.

Shibuya, E. K., Sarkis, J. E. S., Neto, O. N., Moreira, M. Z., Victoria, R. L., 2006. Sourcing Brazilian marijuana by applying IRMS analysis to seized samples. Forensic Science International, 160, 35-43.

Simpson, I.A., Vesteinsson, O., Adderley, P.W., MacGovern, T., 2003. Fuel resource utilization in landscape settlement. Journal of Archaeological Science, 30, 1401-1420.

Stein, J. (Ed), 1992. Deciphering a shell midden. Academic Press, San Diego. 375 p.

Stein, J. 1987. Deposits for archaeologists. In: Schiffer, M. (Ed), Advances in archaeological method and theory. Academic Press, $712 \mathrm{p}$.

Stein, J. 1990. Archaeological stratigraphy. In: Lasca, N.P. e Donahue, J. (Eds). Archaeological geology of north America. Geological Society of America. Centennial Special Volume 4, Boulder, Colorado, 523 p.

Stein, J., Linse, A.R. (Eds), 1993. Effects of scale on archaeological and geoscientific perspectives. The geological Society of America, Boulder. $91 \mathrm{p}$.

Stoops, G., 2003. Guidelines for analysis and description of soil and regolith thin sections. Soil Science Society of America, Madison. 184 p. 
Stuiver, M.; Reimer, P. J., 1993. Extended 14C database and revised CALIB radiocarbon calibration program. Radiocarbon, v. 35, p. 215-230.

Suguio, K., 1980. Rochas sedimentares, propriedades, gênese, importância econômica. Edgard Blucher, São Paulo, 500p.

Suguio, K., Martin, L,. Bittencourt, A.C.S.P., Dominguez, J. M. L.,. Flexor J.-M., Azevedo, A.E.G., 1985. Flutuações do nível relativo do mar durante o quaternário superior ao longo do litoral brasileiro e suas implicações na sedimentação costeira, Revista Brasileira de Geociências, 15, 273-286.

Tanaka, A. P. B., 2007. Evolução sedimentar da planície retrobarreira de Campos Verdes (Laguna, SC) e os sambaquis de Carniça. Monografia de trabalho de formatura, Instituto de Geociências, Universidade de São Paulo, São Paulo.

Tanaka, A. P. B., Fornari, M., Giannini, P. C. F., Nascimento Junior, D. R., Sawakuchi, A. O., Menezes, P. M. L., Rodrigues, S. I., DeBlasis, P., Porsani, J. L. Evolução Sedimentar da Planície de Cordões Litorâneos de Campos Verdes (Laguna, SC). Revista Brasileira de Geociências. No prelo.

Thy, P., Segobye, A. K., Ming, D. W., 1995. Implications of Prehistoric Glassy Biomass Slag from East-Central Botswana. Journal of Archaeological Science, 22, 629-637.

Tucker, M., 1981. Sedimentary Petrology: An introduction. Blackwell Science, Oxford.

Villagrán, X. S., 2008. Análise de arqueofácies na camada preta do Sambaqui de Jabuticabeira II. Dissertação (Mestrado), Museu de Arqueologia e Etnologia, Universidade de São Paulo, São Paulo. 170 p.

Villagrán, X. S., Giannini, P. C. F., DeBlasis, P., 2009. Archaeofacies analysis: Using depositional attributes to identify anthropic processes of deposition in a monumental shell mound of Santa Catarina State, southern Brazil. Geoarchaeology, 24, 311-335.

Yaalon, D. H. \& Fränzle, O., 1975. Working group on rock weathering, soils and sedimentary structures. International Symposium on the Quaternary. Boletim Paranaense de Geociências, 33, 355-356.

Walker, R. G., 2006. Facies models revisited: Introduction. In: Posamentier, H. W. e Walker, R. G. (Eds). Facies models revisited. SEPM Society for Sedimentary Geology, Tulsa, Oklahoma, $527 \mathrm{p}$.

Walker, R.G., 1983. Facies models. Geological Association of Canada, Toronto. 211 p.

White, W. M., 2001. Stable Isotopes. In: White, W. M. (Ed). Geochemistry. 701 p. 